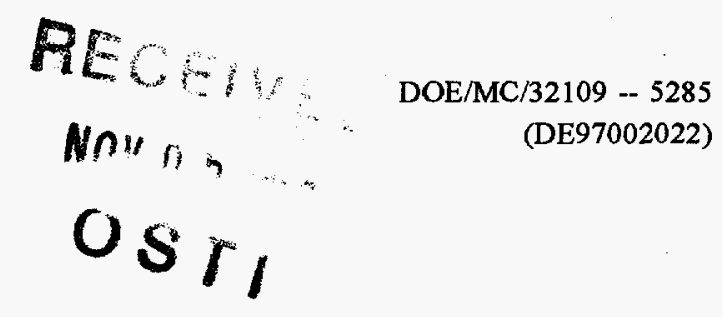

\title{
Barometric Pumping With A Twist: VOC Containment And Remediation Without Boreholes \\ Phase I
}

\section{Topical Report}

August 1996

Work Performed Under Contract No:: DE-AR21-95MC32109

\section{U.S. Department of Energy}

Office of Environmental Management Office of Technology Development

Washington, DC

By

Science and Engineering Associates, Inc.

Santa Fe, NM 87505
For

U.S. Department of Energy Office of Fossil Energy Morgantown Energy Technology Center Morgantown, West Virginia 


\section{DISCLAIMER}

Portions of this document may be illegible in electronic image products. Images are produced from the best available original document. 


\section{Disclaimer}

This report was prepared as an account of work sponsored by an agency of the United States Government. Neither the United States Government nor any agency thereof, nor any of their employees, makes any warranty, express or implied, or assumes any legal liability or responsibility for the accuracy, completeness, or usefulness of any information, apparatus, product, or process disclosed, or represents that its use would not infringe privately owned rights. Reference herein to any specific commercial product, process, or service by trade name, trademark, manufacturer, or otherwise does not necessarily constitute or imply its endorsement, recommendation, or favoring by the United States Government or any agency thereof. The views and opinions of authors expressed herein do not necessarily state or reflect those of the United States Government or any agency thereof. 


\section{Barometric Pumping With A Twist: VOC Containment And Remediation Without Boreholes Phase I}

\section{Topical Report}

Work Performed Under Contract No.: DE-AR21-95MC32109

U.S. Department of Energy

Office of Environmental Management Office of Technology Development 1000 Independence Avenue

Washington, DC 20585
For

U.S. Department of Energy

Office of Fossil Energy

Morgantown Energy Technology Center P.O. Box 880

Morgantown, West Virginia 26507-0880

By

Science and Engineering Associates, Inc.

1570 Pacheco, Suite D-1

Santa Fe, New Mexico 87505 


\section{BAROMETRIC PUMPING WITH A TWIST: VOC CONTAINMENT AND REMEDIATION WITHOUT BOREHOLES PHASE I FINAL REPORT}

TABLE OF CONTENTS

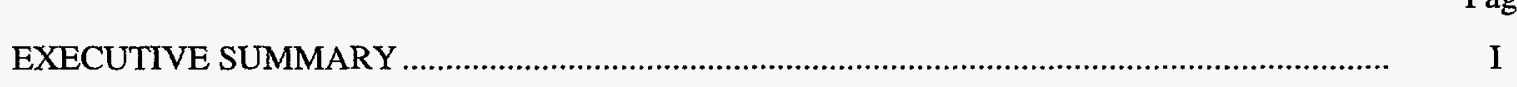

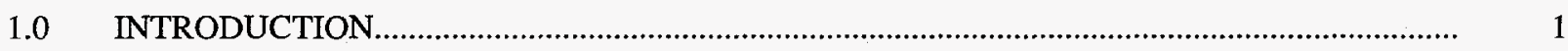

$2.0 \quad$ NATURAL FLOW AND TRANSPORT PROCESSES IN THE VAPOR PHASE .......................... 6

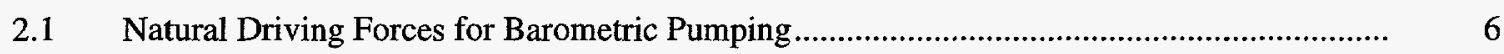

2.2 Advective Movement of Soil Gas Due to Barometric Pumping .......................................... 8

2.3 Diffusive Transport of Volatile Contaminants ..................................................................... 12

2.4 Density Induced Transport of Volatile Contaminants ................................................................ 16

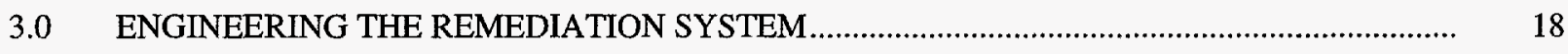

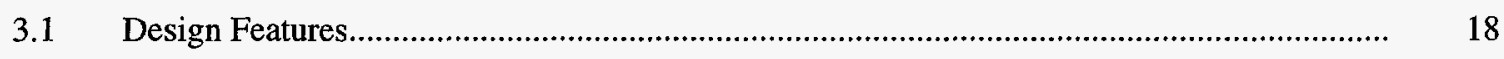

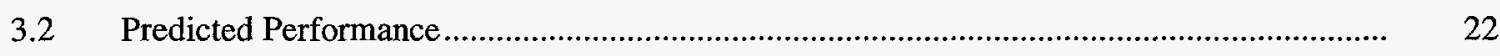

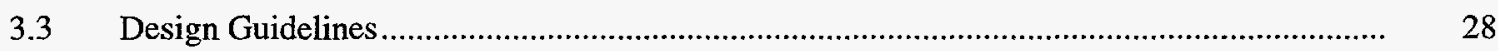

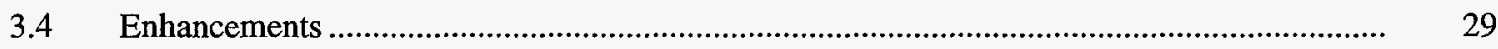

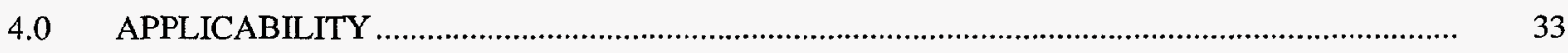

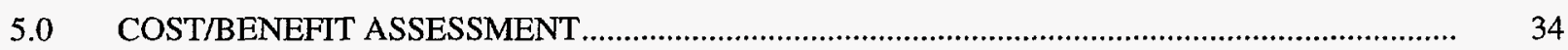

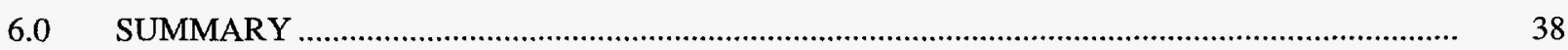

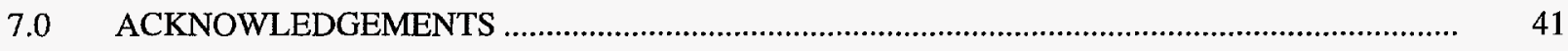

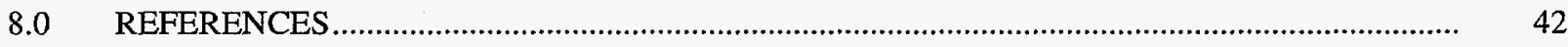

APPENDICES

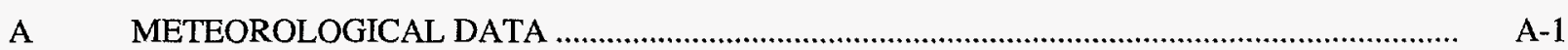

B. DIFFUSIVE TRANSPORT OF VOLATILE CONTAMINANTS …........................................... B-1

C. DENSITY EFFECTS - THERMALLY-INDUCED GRADIENTS …......................................... C-1

D. DENSITY EFFECTS - CONCENTRATION GRADIENTS …............................................... D-1

E. ADVECTION DUE TO BAROMETRIC PRESSURE OSCILLATIONS ..................................... E-1

F. SUMMARY OF CONTAMINANT CHARACTERISTICS ........................................................ F-1 


\section{LIST OF ILLUSTRATIONS}

Figure

1 Barometric pressure, and soil gas pressure response at $95 \mathrm{ft}$. depth, recorded in Albuquerque, NM [1]

2 The surface treatment system controls the movement of soil gas due to barometric pressure changes

3 Barometric pressure, temperature, and wind speed records for Albuquerque, NM, from March 1, 1989 to February 28, 1990. Data is recorded hourly.

4 Piston/cylinder analogy of soil gas movement due to barometric pressure changes (a), and the parameters affecting steady state soil gas displacement due to barometric pressure oscillations (b). $(\mathrm{k}=5$ Darcies, $\varepsilon=0.35, \mathrm{~L}=100 \mathrm{~m})$.

6 Parametric plot of peak soil gas velocity resulting from a daily 5 mbar surface pressure oscillation in soil with $\varepsilon=0.35$, using the analytic model of Section 2.2

7 Concentration profile, mass flux, and minimum advective velocity required to overcome contaminant mass flux of TCE evaporating from a planar one dimensional source

Typical field installation of barometric remediation system

Relief (flapper) valve configuration.

11 Maximum net upward soil gas flux attainable by the surface treatment system, given daily barometric pressure oscillations of 5 mbar and a soil porosity of 0.35

12 Geometry and properties simulated in the FEHM calculation

13 Resulting velocity fields due to the surface treatment.

14 Net resulting soil gas velocities at depths of $0,1,5$, and 10 meters due to surface treatment........

15 Net vertical velocity profile resulting from surface treatment.

16 Conceptual model of plenum design which allows solar heating of the plenum gas to enhance the extraction rate of the remediation system.

A1 Location of sites chosen for analysis

A2 Climatic data for the one year period between March 1, 1989 and February 28, 1990 for Albuquerque, NM

A3 Climatic data for the one year period between March 1, 1989 and February 28, 1990

for Augusta, GA.

A4 Climatic data for the one year period between March 1, 1989 and February 28, 1990 for Boulder, $\mathrm{CO}$.

A5 Climatic data for the one year period between March 1, 1989 and February 28, 1990 for Knoxville, TN

A6 Climatic data for the one year period between March 1, 1989 and February 28, 1990

for Pendelton, OR 
A7 Climatic data for the one year period between March 1, 1989 and February 28, 1990 for Pocatello, ID

A8 Climatic data for the one year period between March 1, 1989 and February 28, 1990 for San Francisco, CA.

A9 Climatic data for a one month period between March 1 and April 1, 1989 for Albuquerque NM.

A10 Yearly temperature fluctuations measured in Albuquerque, NM between January 1, 1970 and January 1, 1991

A11 Result of Fourier transform analysis performed on pressure data collected in Pendelton, OR between March 1, 1989 and February 28, 1990.

A12 Sample of Fourier transform analysis results on seasonal pressure data. Data was collected in Augusta, GA.

B1 Concentration gradient and the required advective velocity required to overcome downward diffusion with a planar TCE saturated source

B2 Concentration gradient and the reequired advective velocity required to overcome downward diffusion with a spherical TCE saturated source

C1 Temperature and resulting gas density profiles resulting from typical annual temperature variations.

Density-induced differential pressure gradient, and advective flow velocity required to overcome this gradient, given the temperature variation in Figure $\mathrm{C} 1$.

D1 Model used to calculate gravitational effect on contaminant profile

D2 Calculated profiles due to density effects caused by concentration gradients assuming spherical diffusion.

D3 Calculated profiles due to density effects caused by concentration gradients assuming planer diffusion

E1 Pressure and velocity fluctuations with time and depth, based on a pressure amplitude of $5 \mathrm{mbar}\left(500 \mathrm{~N} / \mathrm{m}^{2}\right)$ over a 24 hour period

E2 Pressure and velocity fluctuations with time and depth, based on a pressure amplitude of $16 \mathrm{mbar}\left(1600 \mathrm{~N} / \mathrm{m}^{2}\right)$ over an eight day period.

E3 Pressure and velocity fluctuations with time and depth, based on a pressure amplitude of $18 \mathrm{mbar}(1800 \mathrm{~N} / \mathrm{m} 2)$ over a 13 day period.

E4 Calculated maximum pressure and velocity of a depth of $10 \mathrm{~m}$ bgs versus soil porosity

E5 Calculated maximum pressure and velocity at a depth of $10 \mathrm{~m}$ bgs versus soil permeability......

E6 Calculated maximum pressure and velocity at a depth of $10 \mathrm{~m}$ bgs versus depth to the impermeable layer 


\section{LIST OF TABLES}

Table

Page

A1 Summary of statistical analysis performed on data for each site.

A-12

A2 Average amplitudes of pressure oscillations (in mbars) for the defined periods of 1, 8, and 13 days for all sites

A3 Average windspeeds (m/s) for a one year period (March 1, 1989 to February 28, 1990).

A-15

F1 Properties of common contaminants at DOE facilities

F-6

F2 Non-EPA priority toxic pollutants included in the study of chemical contaminants at DOE sites

F-14

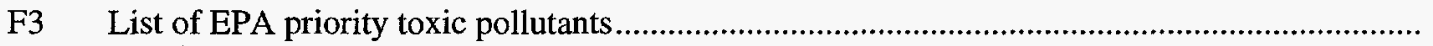

F-15

F4 Specific toxic pollutants defined by the EPA.

F-16

F5 Properties of EPA priority pollutants.

F-18

F6 Calculated maximum vapor concentrations for chemicals of interest.

F-26

F7 Calculated effective diffusivity constants of contaminants in soil with a 35 percent air filled porosity and tortuosities of $0.3,0.5$, and 0.7 . 


\section{EXECUTIVE SUMMARY}

Natural oscillations in barometric pressure induce periodic vertical displacements in soil gas. These displacements can range in amplitude from centimeters to meters, depending on soil gas permeability and depth to the water table. The source of the most rapid soil gas displacement is the daily (diurnal) 5 mbar average variation in barometric pressure. The motions are sinusoidal and do not result in net vertical soil gas displacement over time (except very near the surface of the soil, where the gas releases to the atmosphere on the upward cycle). However, if this process is controlled it offers a continuous, natural, and inexpensive method to remediate VOC plumes in the vadose zone.

Science and Engineering Associates, Inc., has developed a surface treatment design which capitalizes on the naturally occurring barometric pressure oscillations to remediate near surface volatile contamination in the vadose zone. By applying a surface seal, collection plenum, and one way relief valve to the soil surface above the contaminant plume, this system induces a net upward soil gas velocity in the contaminated soil (see the schematic below). The sinusoidal velocity is rectified to eliminate or minimize its downward velocity component and allow the normal upward component. The resulting net upward velocity sweeps contaminant vapors up from the source, releasing them to the atmosphere in small concentrations. This process is regular and steady, and is accomplished without the use of boreholes, off-gas treatment, or site power. Consequently, it is a low cost remediation system, applicable to near surface contamination such as leaking buried pipes, surface spills, buried waste containers, and shallow landfills.

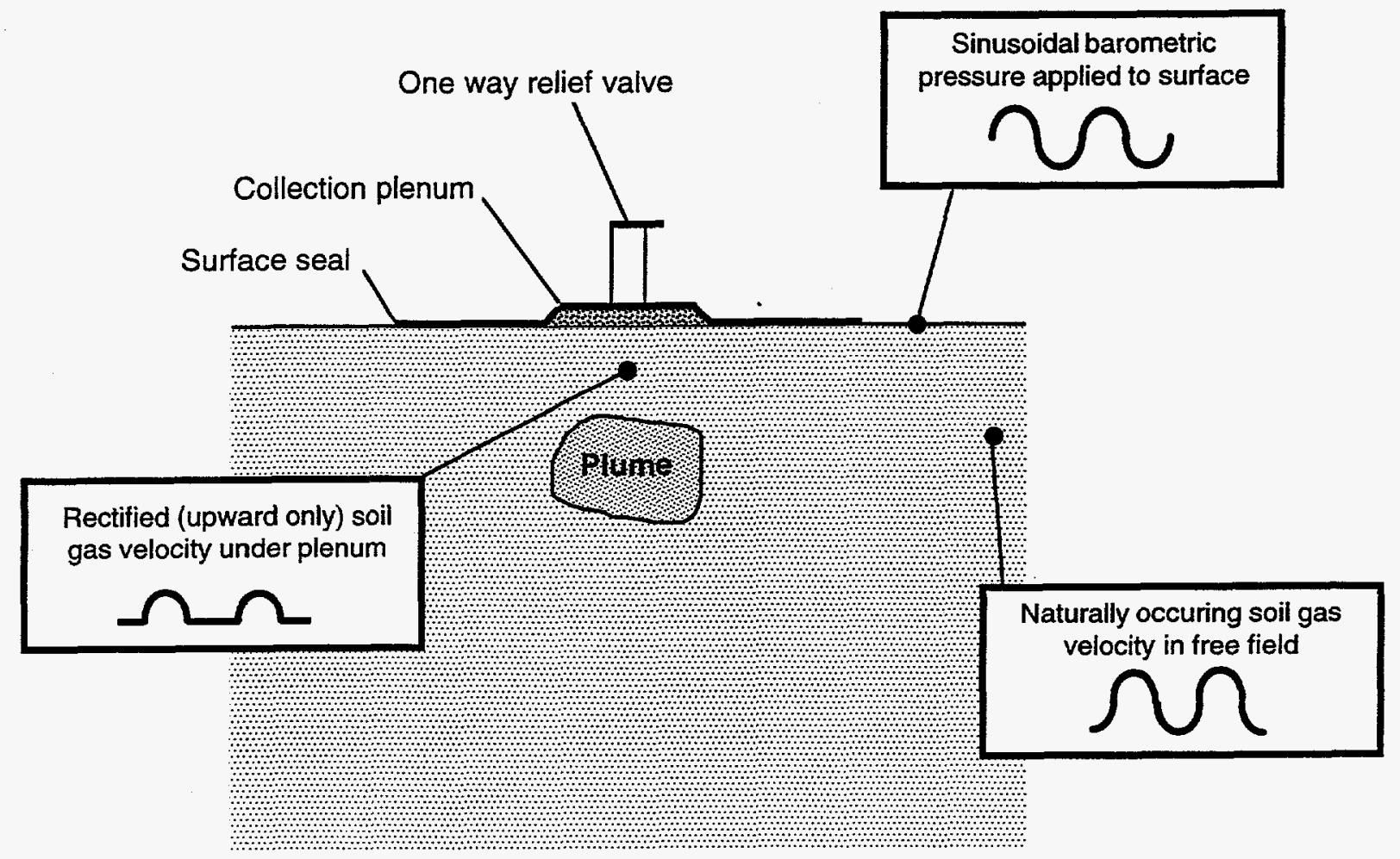


For this system to be practical and cost-effective, it must ensure that most or all of the contaminants evaporating and diffusing from a liquid source in the soil are swept upward. The opposing mechanisms that must be overcome are the diffusion of vapors downward from the source and density driven downward flow caused by thermal and contaminant concentration gradients in the soil gas. To assess the performance, the following tasks were accomplished in this Phase I effort:

- Meteorologic data for seven sites near major DOE installations were reviewed. This established the magnitude, variability, and frequency of barometric pressure oscillations across the nation. Air temperature and wind speed data were also compiled.

- Transport and hazard characteristics of the major volatile contaminants found throughout the DOE complex were summarized to provide data needed for transport calculations.

- The naturally occurring soil gas displacement, due to an oscillatory surface pressure, was predicted for a range of geometric and flow conditions. This analysis defined the highest attainable soil gas velocities under ideal conditions.

- The opposing contaminant transport processes were analyzed to determine the net upward velocities required to overcome the opposing (downward) contaminant transport. These processes include diffusion and density-induced gravitational flow due to concentration and thermal gradients.

- A transient two-dimensional analysis was conducted of a typical surface treatment installation to predict the system's performance. Using the Los Alamos FEHM code, the advective gas flow resulting from the oscillatory surface pressure was predicted throughout the soil volume of interest. Results from this analysis were compared to estimates of contaminant transport rates due to diffusion and density gradients.

- Costs of a typical system installation were compared to remediation costs using conventional techniques.

- Enhancements to the system operation, capitalizing on wind and solar heating, were studied to determine their potential boost to the system's performance.

The data review, analytical modeling, and numerical simulation confirmed that the surface treatment system imposes net upward soil gas velocities at depths typical of shallow soil contamination. Furthermore, the induced velocities were of magnitudes capable of overcoming the downward transport rates due to diffusion and density gradients. The following summaries clarify and support these conclusions.

\section{Naturally occurring air flow rates in soils}

Soil gas moves naturally in soil, and is sinusoidal in nature. Its dominant frequency and magnitude are due to the daily $5 \mathrm{mbar}$ variation which results from heating and cooling of the atmosphere. In higher permeability soil, the velocities will be greater for a given atmospheric pressure variation. Peak velocity also increases as the depth to an impermeable layer increases. The peak soil gas velocity, determined by analytically modeling the soil gas response, will range from 0.2 to $0.8 \mathrm{~m} /$ day for a typical range in permeability ( 1 to 10 Darcies) and depths to an 
impermeable layer of $50 \mathrm{~m}$ or more. Under natural conditions, this oscillatory movement results in no net flow because it always returns to its mean value.

\section{Net soil gas movement due to the surface treatment}

The surface treatment (seal, collection plenum, and vent valve) effectively rectifies the sinusoidal soil gas velocity by minimizing the downward component. This results in a net upward component over time, which is at a maximum just beneath the plenum. The maximum attainable (average) soil gas flux at the surface ranges from 0.03 to $0.07 \mathrm{~m}^{3} / \mathrm{m}^{2}$-day. For a $10 \mathrm{~m}$ diameter plenum, this yields a total soil gas extraction rate of 2.3 to $5.5 \mathrm{~m}^{3} /$ day.

To determine the effects of field conditions, a typical surface treatment was analyzed with a transient multidimensional numerical code to predict the system's performance. The numerical simulation demonstrated that at the soil surface, the system results in a net upward flow equal to the maximum attainable rectified flux. The flow rates predicted numerically were compared with processes which would transport contaminants downward toward the water table. These processes are: concentration-induced density gradients, diffusion, and temperature-induced density gradients. Each of these mechanisms results in a maximum transport rate at the source, which diminishes with depth. The key results of the comparison are:

Concentration induced density gradients - The density gradients resulting from the contaminant concentration distribution (due to diffusion from the source) impose a downward flow from the source. The advective velocity resulting from the surface treatment system is capable of exceeding the downward transport rate with a source as deep as $4 \mathrm{~m}$.

Diffusion - The surface treatment system induces soil gas velocities which overpower the downward diffusion rates. For a planar contaminant source, the net advective upward velocity exceeded downward diffusion of TCE for a source as deep as $10 \mathrm{~m}$.

Thermally induced density gradients - Seasonal heating and cooling of the soil surface will cause temperature gradients in the soil which will induce density gradients in the soil gas. This is shown to be the easiest of the three transport processes to overcome: the surface treatment causes a net upward velocity almost ten times that required to overcome the temperature induced buoyant flow.

\section{Contaminant removal rate}

The maximum attainable contaminant removal rate is defined by how readily the contaminants evaporate and diffuse away from the source. This is true if the surface treatment system sweeps all the contaminated vapors upward from a source, which the analysis predicts to be the case. The maximum TCE transport rate from a planar source is $0.1 \mathrm{mg} / \mathrm{s}-\mathrm{m}^{2}$. If the source is $5 \mathrm{~m}$ in diameter and the TCE diffuses from both the top and bottom of the 
source, this translates to a daily removal rate of $0.34 \mathrm{~kg}$, or $124 \mathrm{~kg} /$ year. Total remediation time will depend on the mass of contaminants present, but will likely range from one to several years.

\section{Cost effectiveness}

An estimate of the cost to install this system was compared to estimates of conventional remediation technologies. A baseline barometric pumping installation, covering a contaminant source roughly $10 \mathrm{~m}$ in diameter, is estimated to cost $\$ 28 \mathrm{~K}$. This is less than half the cost estimated for conventional solutions.

\section{Applicability}

The system is applicable to volatile contamination from sources such as leaking underground storage tanks, buried pipelines, surface spills, and landfills in the vadose zone. The process is slow but steady, and may take several years to adequately remediate a site. Its depth of influence is adequate to treat many of these circumstances. The system is very inexpensive, requires virtually no maintenance, and can treat many of the sites in which no immediate threat to the water table exists. Installations can be unobtrusive: parking lots and concrete pads can actually be part of the surface seal while allowing the land to be used for other purposes. 


\section{SECTION 1.0}

\section{INTRODUCTION}

The majority of the planned remediation sites within the DOE complex are contaminated with volatile organic compounds (VOCs). In many instances the contamination has not reached the water table, does not pose an immediate threat, and is not considered a high priority problem. These sites will ultimately require remediation of some type, either by active vapor extraction, bioremediation, or excavation and ex-situ soil treatment. The cost of remediating these sites can range from $\$ 50 \mathrm{~K}$ to more than $\$ 150 \mathrm{~K}$, depending on site characteristics, contaminants, and remediation method. Additionally, for many remediated sites, residual contamination exists which could not practically be removed by the applied remediation technology. These circumstances result in modest sites with contamination of limited risk, but by regulation they must still be controlled. A remediation solution being developed by Science and Engineering Associates, Inc. (SEA) for the Department of Energy serves as an in-situ containment and extraction methodology for sites where most or all of the contamination resides in the vadose zone soil. The approach capitalizes on the advective soil gas movement resulting from barometric pressure oscillations.

Oscillations in barometric pressure are both diurnal, corresponding to daily heating and cooling of the atmosphere, and of longer time periods, resulting from the passage of weather fronts. Daily variations will average about 5 millibars (one millibar is roughly one thousandth of an atmosphere) while those due to weather front passage can be $\mathbf{2 5}$ or more millibars. As the barometric pressure rises, a gradient is imposed on the soil gas which drives fresh surface air into the soil. As it drops, gas vents upward from the soil into the atmosphere. The pressure changes and resulting gradient are depicted in Figure 1, which shows data recorded in Albuquerque, NM [1]. The total movement of soil gas is dependent primarily on the magnitude and period of the pressure oscillations, the soil gas permeability, and the depth to an impermeable boundary. This boundary can be the water table, bedrock, or extensive layers of very low permeability material, such as caliche or clay. Since the fractional change in atmospheric pressure is small (typically 0.5 percent) the overall soil gas displacement during the daily cycle is also small (with an estimated range of centimeters to meters). Furthermore, the daily oscillations in atmospheric pressure always return to a mean value. Over time, no net soil gas displacement occurs in a homogeneous medium due to barometrically-induced advective forces alone.

Displacement of soil gas can be controlled using surface features which impede the downward movement of vapors, but allow upward movement. The design incorporates a surface seal, a plenum, and an extraction vent valve. These components are depicted in Figure 2. 


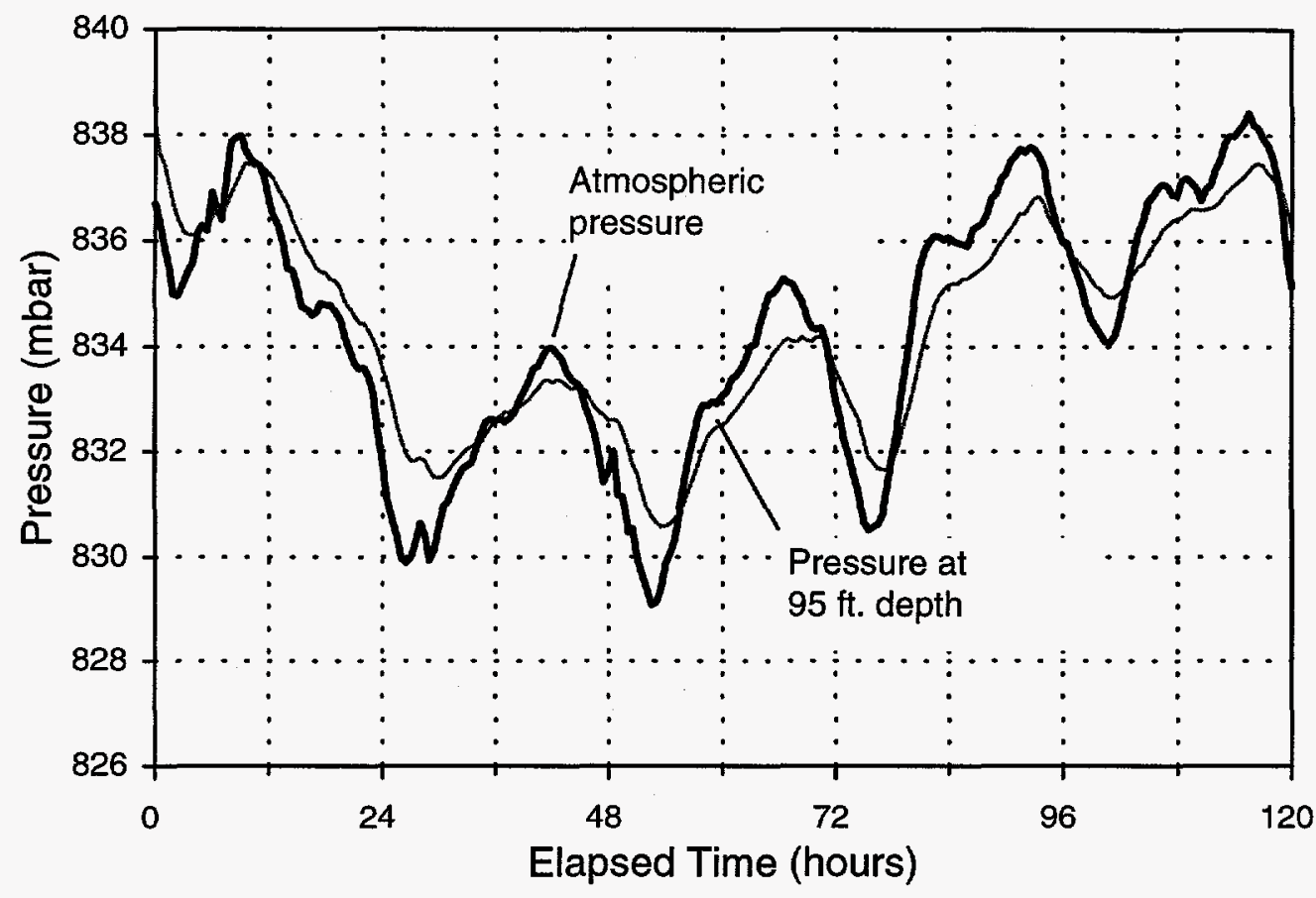

Figure 1. Barometric pressure, and soil gas pressure response at $95 \mathrm{ft}$. depth, recorded in Albuquerque, NM [1].

Directly above the contaminant plume is a layer of highly permeable material, such as pea gravel, which forms a collection plenum for the upward-moving soil gas. A surface seal is placed outward from the collection plenum directly on the soil surface to form a buffer zone which controls the radial movement of air flowing into the soil during the high pressure periods. The surface seal is an impermeable, rugged material (such as a geotechnical membrane) which forms a no-flow boundary at the ground surface. The plenum is connected to atmospheric pressure with a high volume vent valve, open only when soil gas is moving upward (during a drop in the barometric pressure).

In operation the system ratchets the soil gas upward by allowing normal upward flow during barometric lows but restricting downward air flow during high pressure cycles. High pressure periods result in restricted downward gas movement because the vent valve is closed and soil gas flows around the plume ("inhaling"). When the atmospheric pressure is lower than the soil gas pressure at depth, soil gas flows upward and the surface seal forces the contaminated gas into the plenum, where the opened vent valve exhausts it to the atmosphere ("exhaling"). 

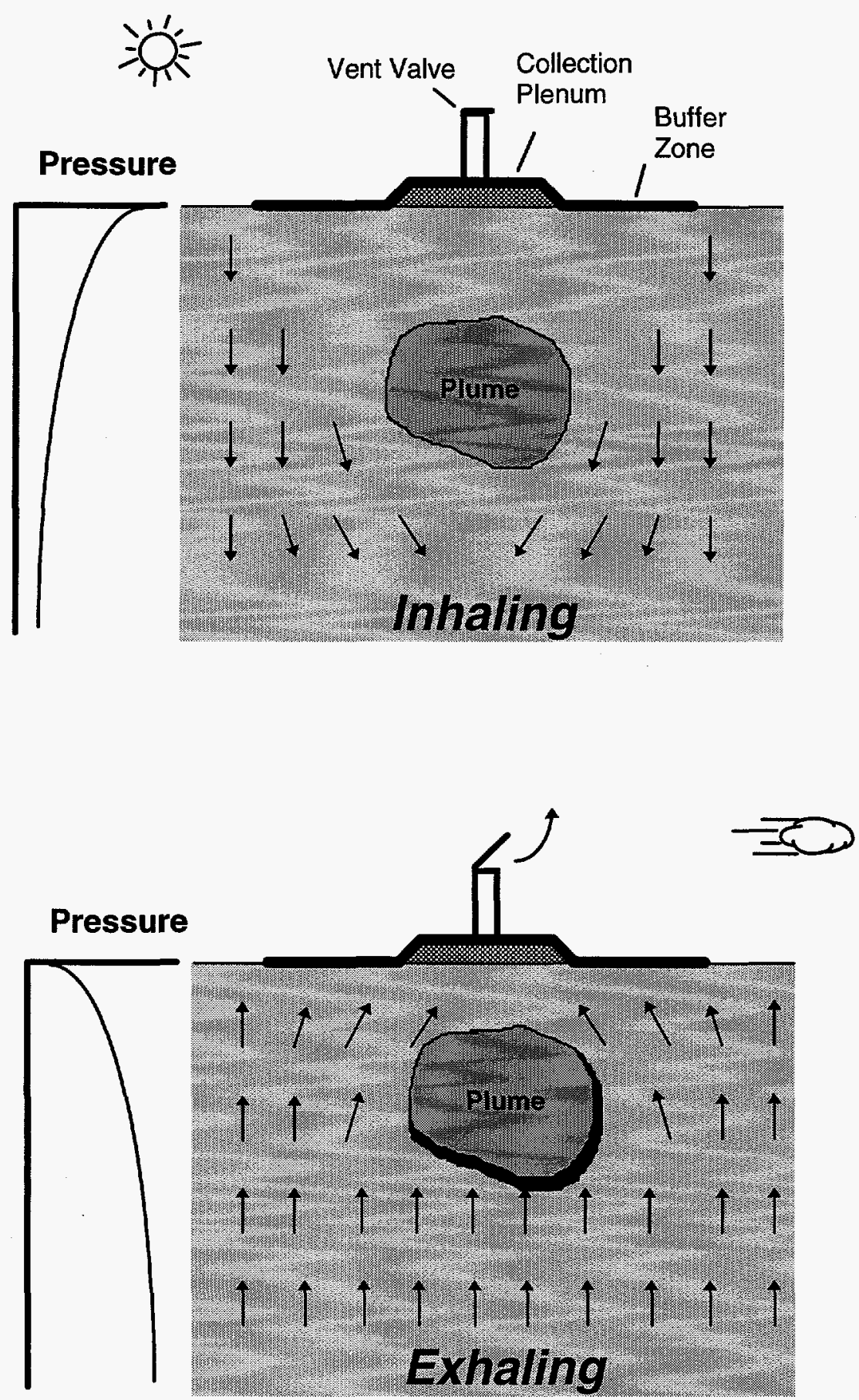

Figure 2. The surface treatment system controls the movement of soil gas due to barometric pressure changes. 
The objective of this Phase I effort is to evaluate the feasibility of applying surface sealing and venting features to contain and remediate volatile organic compound (VOC) contaminated soils in the vadose zone. The contract statement of work includes two tasks for this phase:

\section{Task 1. Analysis of Advective and Diffusive Processes under Barometric Pumping}

Using analytical and numerical porous flow models, the contractor shall predict the flow of soil gas due to barometric processes. This work will include the geometric configuration of the surface seal design, with plenum and buffer zone dimensions. The modeling will evaluate the sensitivity of the extraction rate to plenum areal extent, and buffer zone size, particularly in relation to the depth and size of the plume. The analysis will also compare the advective gas flow caused by barometric pumping to the estimated diffusion rate of typical contaminants. A commercial porous flow code will be used for static analysis, and analytical and simplified numerical solutions will be used to model the transient response.

\section{Task 2. General Design of Containment/Remediation System}

Given the results of parametric evaluations of Task 1, the contractor shall develop general design guidelines for the implementation of the barometric pumping system. The guidelines will define the relationship between plenum size, buffer zone configuration, plume depth and geometry, and geologic setting (depth to impermeable zone). The contractor shall also develop monitoring requirements, to include a general monitoring system design. The contractor shall also estimate the cost of a prototypical installation.

This report documents the Phase I effort, which consisted of the following technical activities:

- Meteorologic data for seven sites, selected based on their proximity to major DOE installations, was reviewed. This analysis established the magnitude, variability, and frequency of barometric pressure oscillations. Air temperature and wind speed data were also compiled.

- Transport and hazard characteristics of the major volatile contaminants found across the DOE complex were summarized.

- The naturally occurring soil gas displacement, due to an oscillatory surface pressure, was predicted for a range of geometric and flow conditions. This analysis defined the highest attainable upward soil gas velocities under ideal conditions.

- The opposing contaminant transport processes were analyzed to determine the net upward velocities required to overcome the opposing (downward) contaminant transport. These processes include diffusion and density-induced gravitational flow due to concentration and thermal gradients.

- A transient two-dimensional analysis was conducted of a typical installation to predict the system's performance. Using the Los Alamos FEHM code, the advective gas flow resulting from the oscillatory surface pressure was predicted throughout the soil volume of interest.

- Enhancements to the system operation, capitalizing on wind and solar heating, were studied to determine their potential boost to the system's performance.

- Costs of a typical system installation were compared to remediation costs using conventional techniques. 
The main text of this report includes the general description of the system, an overview of the processes causing flow and transport of vapors in the vadose zone, a summary of the design features and predicted performance of the system, a cost assessment, and the range of applicability of the system.

The details of the data review and analysis is provided in the appendix, with individual section on meteorological data, diffusive transport, density effects due to thermal and concentration gradients, advective flow due to oscillatory pressure, and a general summary of volatile contaminant transport and hazard characteristics. 


\section{SECTION 2.0}

\section{NATURAL FLOW AND TRANSPORT PROCESSES IN THE VAPOR PHASE}

\subsection{Natural Driving Forces for Barometric Pumping}

Changes in barometric pressure occur due to regular diurnal variations in the atmospheric temperature and less frequent changes due to weather front passage. Since this is the driving mechanism for the barometric pumping remediation system, it is important to understand the characteristics of the natural variations. A data base from the National Climatic Data Center (U.S. Weather Service) was searched for barometric pressure, temperature, and windspeed data for the cities listed below (selected for their proximity to DOE sites).

\begin{tabular}{|l|l|}
\hline \multicolumn{1}{|c|}{ City } & \multicolumn{1}{c|}{ Relevant DOE Site(s) } \\
\hline \hline Albuquerque, NM & Sandia Albuquerque, Los Alamos \\
Augusta, GA & Savannah River \\
Boulder, CO & Rocky Flats \\
Knoxville, TN & Oak Ridge \\
Pendelton, OR & Hanford \\
Pocatello, ID & INEL \\
San Francisco, CA & Lawrence Livermore, Sandia Livermore \\
\hline
\end{tabular}

The results of this survey are detailed in Appendix A, where statistical and Fourier analyses were performed on the data sets. They are summarized below.

\section{Barometric Pressure}

Statistical analysis of the seven sites showed that the magnitudes of daily barometric pressure variations at these sites are similar. For the one year period analyzed, the average daily (diurnal) variations ranged from 3.6 to 5.5 mbar. For the longer periods ( 8 and 13 day periods) the variations increased to magnitudes of 12 to almost 22 mbar. In general at all sites the summer months experienced fewer (and also lower magnitude) of the larger weather front driven variations. The barometric pressure data for Albuquerque, NM is reproduced in Figure 3, plotted for one year. Diurnal variations are shown in detail in Figure 1. 



\section{Temperature}

Temperature variations are of interest because they influence the soil temperature and its resulting impact on soil gas density gradients. Average temperature is dictated primarily by elevation and latitude. Pocatello, ID (near INEL) exhibited the lowest average temperature $\left(8.89^{\circ} \mathrm{C}\right.$ ) and Augusta, GA (near Savannah River) the highest $\left(17.63^{\circ} \mathrm{C}\right)$. The greatest standard deviation occurs in Albuquerque, NM $\left(10.46^{\circ} \mathrm{C}\right)$, and the lowest in San Francisco, $\mathrm{CA}\left(4.33^{\circ} \mathrm{C}\right)$. Temperature data is also shown in Figure 3.

\section{Wind speed}

While it is meteorologically coupled to pressure and temperature, windspeed is most relevant to barometric pumping because features can be added to the surface treatment to enhance the vertical displacement of soil gas. Average yearly windspeed ranged from $2.71 \mathrm{~m} / \mathrm{s}$ (Augusta) to $4.97 \mathrm{~m} / \mathrm{s}$ (San Francisco). The standard deviation is relatively uniform across all sites, ranging from $2.10 \mathrm{~m} / \mathrm{s}$ (Knoxville) to $3.0 \mathrm{~m} / \mathrm{s}$ (San Francisco). See Figure 3, where windspeed over a one year period is plotted for Albuquerque, NM. Wind speed tends to follow a 24-hour cycle, with peak speeds occurring in the late afternoon and early evening.

\subsection{Advective Movement of Soil Gas Due to Barometric Pumping}

In a homogeneous medium the movement of soil gas caused by fluctuations in the surface barometric pressure is analogous to the displacement of a piston in a cylinder (Figure 4). As the barometric pressure $\left(\mathrm{P}_{1}\right)$ rises, the piston is displaced downward a distance $\Delta \mathrm{x}$ until the barometric pressure $\left(\mathrm{P}_{1}\right)$ equilibrates with the soil gas pressure below $\left(\mathrm{P}_{2}\right)$. In the absence of diffusion or density-related forces a molecule of soil gas will undergo the same displacement as the piston. In soil, the displacement is estimated by:

$$
\Delta \mathrm{x}=\frac{\Delta \mathrm{P}}{\mathrm{P}_{\mathrm{amb}}}(\mathrm{L}-\mathrm{d})
$$

where $\Delta \mathrm{P}$ is the amplitude of the cyclic variation in barometric pressure, $\mathrm{Pamb}$ is the average barometric pressure, $\mathrm{d}$ is the depth of the gas in the soil, and $\mathrm{L}$ is the depth below surface to an impermeable layer such as bedrock, clay, caliche, or the water table. This is a steady state relation, appropriate if the soil gas response is relatively rapid (i.e., $L$ is less than the penetration depth of the pressure pulse. 


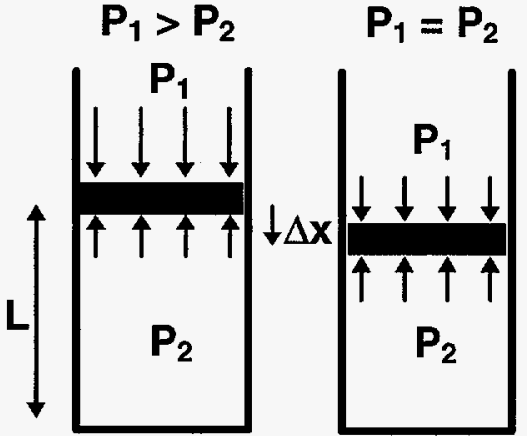

(a)

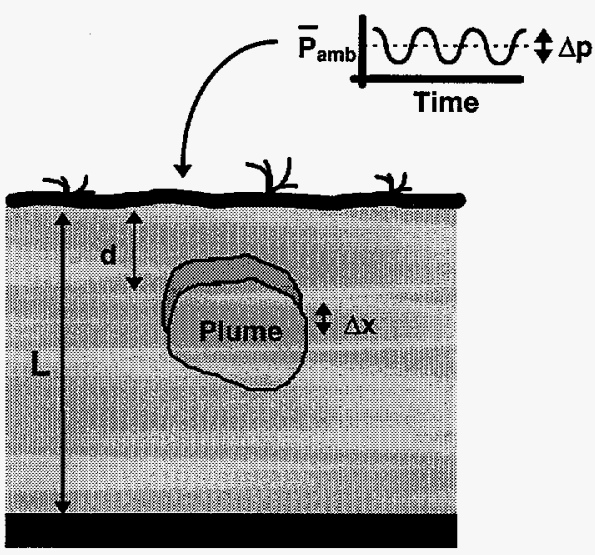

(b)

Figure 4. Piston/cylinder analogy of soil gas movement due to barometric pressure changes (a), and the parameters affecting steady state soil gas displacement due to barometric pressure oscillations (b).

Using Equation 1 it is possible to predict the maximum attainable movement of soil gas. For example, given a 5 mbar pressure change and depth to the water table of $100 \mathrm{~m}$, soil gas at $5 \mathrm{~m}$ will displace:

$$
\Delta \mathrm{x}=\frac{5 \mathrm{mbar}}{1000 \mathrm{mbar}} \bullet(100 \mathrm{~m}-5 \mathrm{~m})=0.475 \mathrm{~m}
$$

For the same setting a 50 mbar change will result in $4.75 \mathrm{~m}$ total displacement. Since the barometric pressure always returns to its original value, this displacement is oscillatory and results in no net vertical movement, except very near the surface where release directly to the atmosphere occurs on each upward cycle.

Soil gas permeability, however, is rarely so high that the soil gas will displace to the maximum steady state value predicted by Equation 1. A transient analytic model was developed to allow calculation of the soil gas velocities resulting from varied geometric and flow characteristics of the soil. The model and calculational results are described in detail in Appendix E; they will be summarized in this section.

The model assumes an isotropic, homogeneous medium of some finite thickness. An impermeable barrier, such as a clay layer or the water table, is located at the bottom of the medium, and a sinusoidal pressure is applied to the surface. Gravitational effects are neglected. The flow is modeled with the standard differential equation for one dimensional porous flow in a uniform medium:

$$
\frac{\delta \mathrm{p}(\mathrm{x}, \mathrm{t})}{\delta \mathrm{t}}=\alpha \frac{\delta^{2} \mathrm{p}(\mathrm{x}, \mathrm{t})}{\delta \mathrm{x}^{2}}, \quad 0<\mathrm{x}<\mathrm{L},-\infty<\mathrm{t}<\infty
$$


where $\mathrm{p}(\mathrm{x}, \mathrm{t})$ is the pressure of the pore gas at time $t$, at a depth $\mathrm{x}$ from the surface, and $\alpha$ is the uniform diffusivity of the medium. The boundary condition at the impermeable barrier is zero vertical pore gas velocity, which requires that the pressure gradient go to zero in accordance with

$$
\lim _{x \rightarrow L} \frac{\delta p(x, t)}{\delta x}=0, \quad-\infty<t<\infty
$$

The other boundary condition is the sinusoidal surface pressure, with the form

$$
\mathrm{p}(0, \mathrm{t})=\mathrm{p}_{\mathrm{o}}+\Delta \mathrm{p} \cos \left(\frac{2 \pi \mathrm{t}}{\mathrm{T}}\right), \quad-\infty<\mathrm{t}<\infty
$$

with $p_{o}$ being the mean pressure, $\Delta p$ the amplitude and $T$ the period of the pressure oscillation.

The use of complex functions facilitates the solution. The complex function $q(x, t)$ is defined such that $p(x, t)$ is the real part of $q(x, t)$ and $\alpha$ is the pneumatic diffusivity:

$$
\begin{aligned}
& \frac{\delta \mathrm{q}(\mathrm{x}, \mathrm{t})}{\delta \mathrm{t}}=\alpha \frac{\delta^{2} \mathrm{q}(\mathrm{x}, \mathrm{t})}{\delta \mathrm{x}^{2}}, \quad 0<\mathrm{x}<\mathrm{L}, \quad-\infty<\mathrm{t}<\infty, \\
& \lim _{\mathrm{x} \rightarrow \mathrm{L}} \frac{\delta \mathrm{q}(\mathrm{x}, \mathrm{t})}{\delta \mathrm{x}}=0, \quad-\infty<\mathrm{t}<\infty, \text { and } \\
& \mathrm{q}(0, \mathrm{t})=\mathrm{p}_{\mathrm{o}}+\Delta \mathrm{p} \exp \left(\mathrm{i} \frac{2 \pi \mathrm{t}}{\mathrm{T}}\right), \quad-\infty<\mathrm{t}<\infty .
\end{aligned}
$$

These equations are satisfied by

$$
\mathrm{q}(\mathrm{x}, \mathrm{t})=\mathrm{p}_{\mathrm{o}}+\Delta \mathrm{p} \frac{\cosh [\mathrm{K}(\mathrm{L}-\mathrm{x})(1+\mathrm{i})]}{\cosh [\mathrm{KL}(1+\mathrm{i})]} \exp \left(\mathrm{i} \frac{2 \pi \mathrm{t}}{\mathrm{T}}\right), \quad 0<\mathrm{x}<\mathrm{L}, \quad-\infty<\mathrm{t}<\infty,
$$

where

$$
\mathrm{K}=\sqrt{\frac{\pi}{\alpha \mathrm{T}}}
$$

The solution takes the form of

$$
\left|q(x, t)-p_{o}\right|=\Delta p \sqrt{\frac{\cosh [2 K(L-x)]+\cos [2 K L(L-x)]}{\cosh [2 K L]+\cos [2 K L]}}
$$


and

$$
\arg \left(q-p_{o}\right)=\frac{2 \pi T}{t}+\theta-\beta
$$

where $\theta$ and $\beta$ are dependent upon the parameters $K, L$, and $x$.

Similarly, the flux can be calculated as:

$$
\frac{\delta \mathrm{p}}{\delta \mathrm{x}}=\left|\frac{\delta \mathrm{q}}{\delta \mathrm{x}}\right| \cos \left[\arg \left(\frac{\delta \mathrm{q}}{\delta \mathrm{x}}\right)\right],
$$

where

$$
\frac{\delta q}{\delta x}=K \Delta p \sqrt{2 \frac{\cosh [2 K(L-x)]-\cos [2 K(L-x)]}{\cosh [2 K L]+\cos [2 K L]}}
$$

and

$$
\arg \left(\frac{\partial \mathrm{q}}{\partial \mathrm{t}}\right)=\frac{2 \pi \mathrm{t}}{\mathrm{T}}+\frac{5 \pi}{4}+\gamma-\beta
$$

where $\gamma$ is dependent upon the parameters $K, L$, and $x$.

In Appendix E the effects of variations in pressure history amplitude, soil permeability, soil porosity, and depth to the impermeable layer are analyzed in detail. As a general illustration of the process, a site with a permeability of 5 Darcies, porosity of 0.35 , diurnal fluctuations of $5 \mathrm{mbar}$, and a depth to the impermeable layer of $100 \mathrm{~m}$ is depicted in Figure 5. The surface plot illustrates the degree of attenuation in the pressure response at depth. This response would be typical of a setting such as found in Albuquerque, where the soil consists primarily of alluvial deposits and there is a relatively deep water table.

This model was also applied to evaluate a range of conditions and their impact on bulk soil gas movement at $1 \mathrm{~m}$ depth in soil. These conditions were selected to represent values typical of vadose zones:

- Air permeability (k): 0.1 to 100 Darcies

- Depth to impermeable layer (L): 10 to $100 \mathrm{~m}$

- Soil gas-filled porosity: 0.35

The parametric plot encompassing these results is shown in Figure 6, which represents the effect on soil gas movement in the form of peak soil gas velocity (simply taken as the maximum velocity resulting from the model). Peak velocities ranged from 0.2 to $0.8 \mathrm{~m} /$ day for permeabilities ranging from 1 to 10 Darcies and depths to the impermeable zone from 30 to more than $50 \mathrm{~m}$. A notable feature of this plot is that for low permeabilities (less than 1 Darcy) the depth to the impermeable layer has little effect on the peak attainable velocity. With a soil permeability of 1 Darcy, an impermeable layer depth any greater than $20 \mathrm{~m}$ does not yield increased soil gas velocity because the pressure pulses do not penetrate beyond this depth. This becomes even more pronounced at 0.1 Darcy, where there is little discernable increase in peak velocity with any increase in depth to the impermeable layer past $10 \mathrm{~m}$. 
On the other hand, with a soil permeability of 10 Darcies, increasing the depth to the water table from 10 to $50 \mathrm{~m}$ results in proportionally greater peak soil gas velocities. At 100 Darcies, the peak velocity increases linearly all the way to the value of $100 \mathrm{~m}$ to the impermeable depth. At high permeabilities such as 100 Darcies, the soil gas displacements approach the maximum steady state displacements predicted in Equation 1.

\subsection{Diffusive Transport of Volatile Contaminants}

If the only issue is to advectively move air molecules toward the surface, then this would be a very simple and certain remediation design. However, volatile contamination sources typically exist as liquid deposits in the soil. The liquid evaporates and results in an initial vapor concentration in air $\left(\mathrm{C}_{0}\right)$ immediately adjacent to the liquid. Contaminant vapor diffuses away form the source at a rate governed by the diffusion constant of the contaminant in soil gas, the porosity of the soil, the soil tortuosity (deviation from a straight line path through the soil pores), sorption of the contaminant into the soil, the ability of the adjacent soil to supply adequate thermal energy to vaporize the liquid contaminant, and other effects.

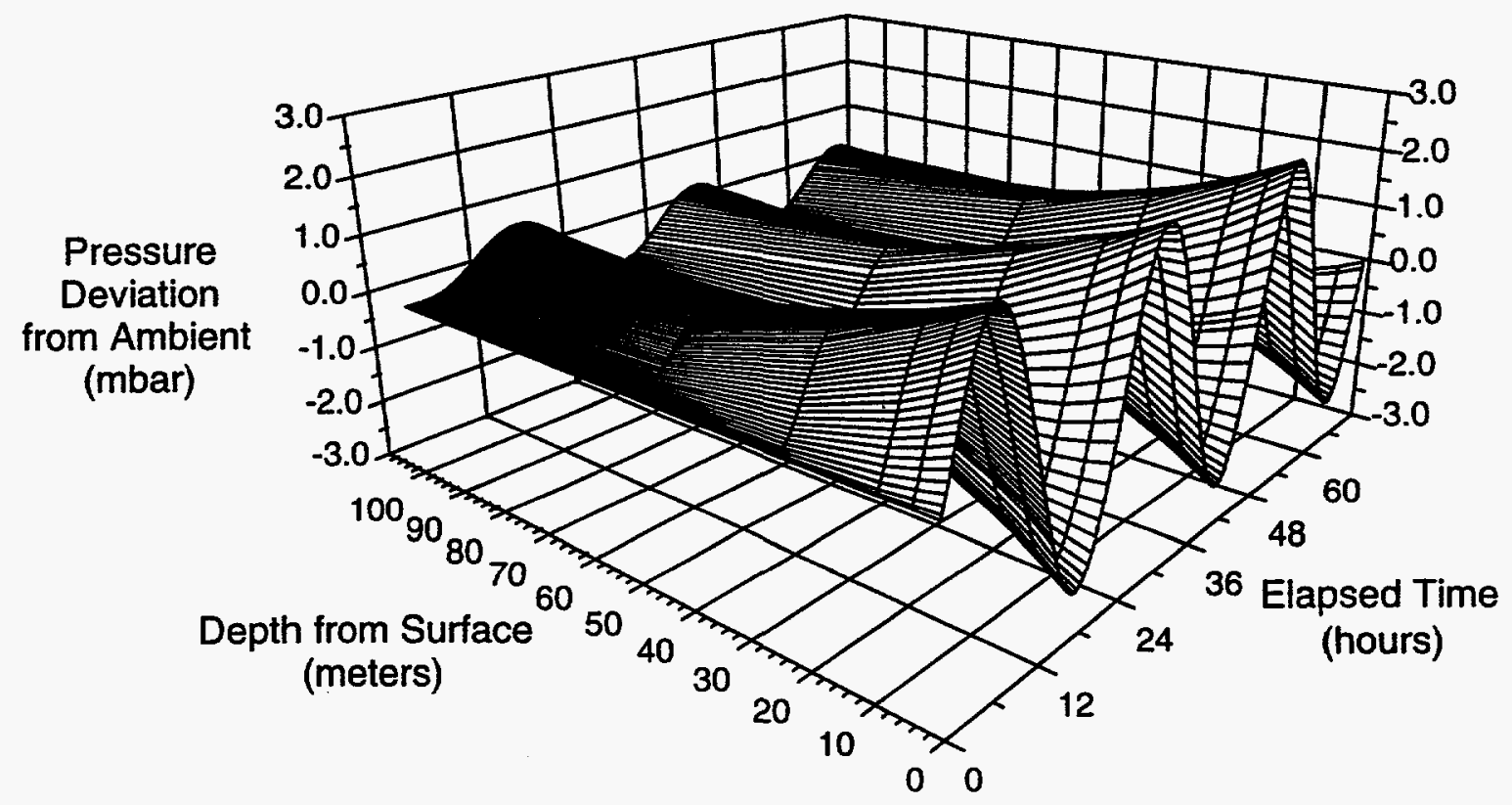

Figure 5. Pressure response in soil due to $5 \mathrm{mbar}$ daily barometric pressure changes $(\mathrm{k}=5$ Darcies, $\varepsilon=0.35, \mathrm{~L}=100 \mathrm{~m})$. 


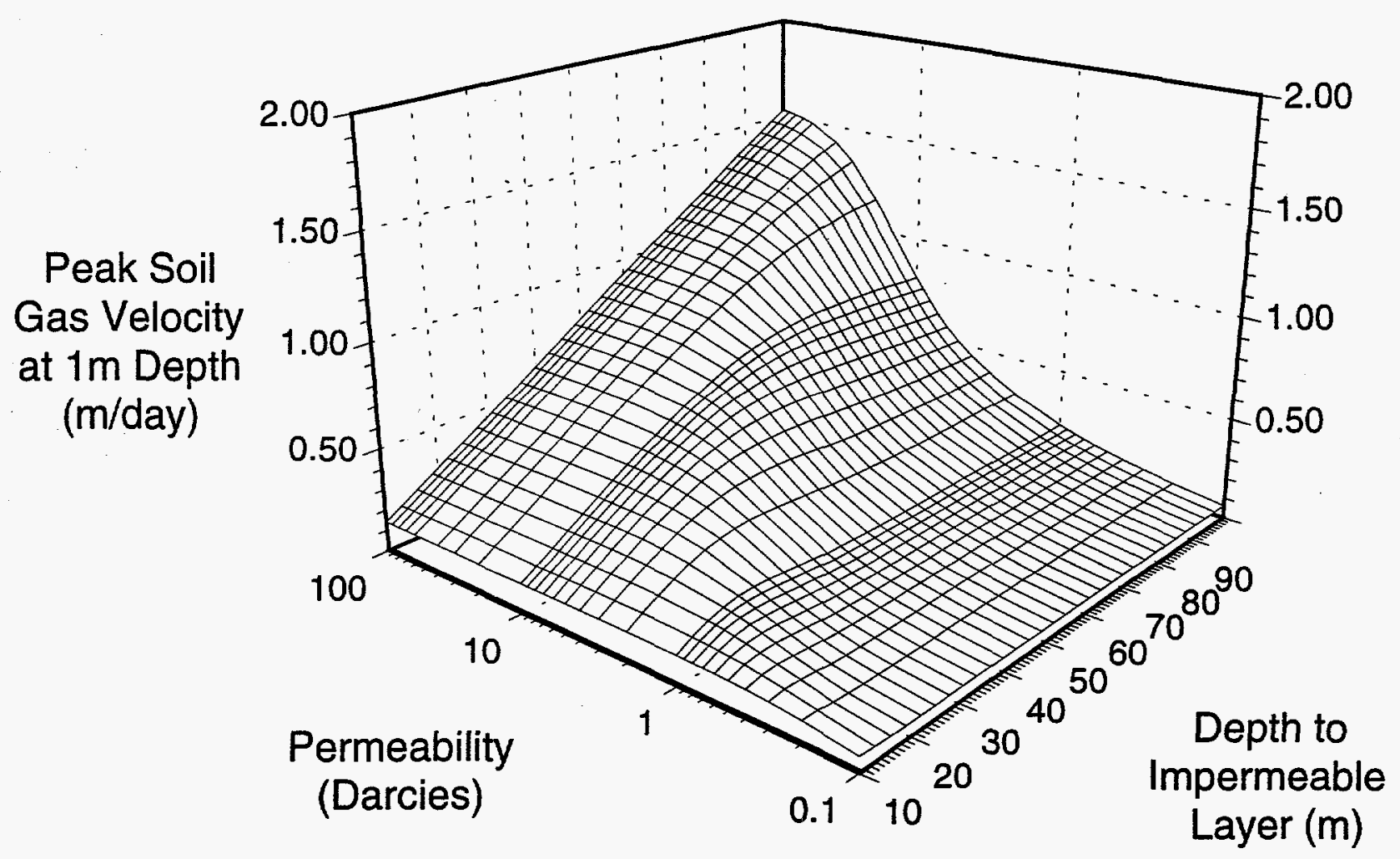

Figure 6. Parametric plot of peak soil gas velocity resulting from a daily 5 mbar surface pressure oscillation in soil with $\varepsilon=0.35$, using the analytic model of Section 2.2 .

The molecular diffusive flux of a single contaminant is:

$$
q_{m}=-D \frac{d C}{d x}
$$

where $\mathrm{D}$ is the effective diffusivity constant of the contaminant through the soil pore space at specified values of temperature and pressure. In Appendix $F$ the range of chemical contaminants present throughout the DOE complex was summarized. This summary includes the compound's diffusivity in air and its vapor pressure, which is used to calculate the initial steady state concentration from an evaporating liquid source. These values are used in the subsequent transport analysis.

Analysis of soil gas diffusion is mathematically analogous to heat transfer, where gas concentration is substituted for temperature and an effective soil diffusivity is substituted for the heat transfer constant. The model treated in this section is a one-dimensional, transient planar model for a semi-infinite solid. This model is appropriate for distributed contaminant sources. Sorption is ignored. This planar model, and a model for a spherical flow geometry, are derived in detail in Appendix B. 
The equation for planar one-dimensional transient heat flow in a semi-infinite solid is:

$$
\frac{\partial^{2} \mathrm{C}}{\partial \mathrm{x}^{2}}=\frac{1}{\mathrm{D}} \frac{\partial \mathrm{C}}{\partial \mathrm{t}}
$$

where: $C=$ concentration

$\mathrm{t}=$ time

$\mathrm{D}=$ effective diffusivity constant of the contaminant through soil pores $=\frac{\mathrm{D}_{\mathrm{a}} \tau}{\varepsilon}$

$\mathrm{D}_{\mathrm{a}}=$ diffusivity constant of the gas in air

$\mathrm{x}=$ distance from boundary

$\tau=$ tortuosity of the medium

$\varepsilon \quad=$ gas filled porosity of the medium

For the case of a constant source concentration, this is solved by:

$$
\frac{C(x, t)-C_{o}}{C_{i}-C_{o}}=\operatorname{erf}\left(\frac{x}{2 \sqrt{D t}}\right)
$$

The mass flux of the contaminant is:

$$
\dot{\mathrm{m}}_{\text {contaminant, diffusion }}=\frac{\mathrm{q}_{\mathrm{m}}}{\mathrm{A}}=\frac{\mathrm{D} \cdot \mathrm{C}_{\mathrm{o}}}{\sqrt{\pi \mathrm{Dt}}} \mathrm{e}^{-\mathrm{x}^{2} / 4 \mathrm{Dt}}
$$

To determine if the barometric pumping remediation system can cause sufficient net upward soil gas flow to overcome the downward diffusion of contaminants in the soil, we can calculate the minimum advective velocity required to counter the diffusive mass transport rate. This velocity can be determined by equating the diffusive mass transport rate with that which would occur from the advective flow of contaminated soil gas:

$$
\dot{\mathrm{m}}_{\text {contaminant, advective }} \geq \dot{\mathrm{m}}_{\text {contaminant, diffusion }}
$$

If barometric pressure oscillations are assumed to be the greatest contributor of advective flow, then the mass flux due to advective flow becomes:

$$
\dot{\mathbf{m}}_{\text {contaminant, advective }} \geq \mathrm{v}_{\text {soil gas }} \bullet \mathrm{C}(\mathrm{x}, \mathrm{t})
$$

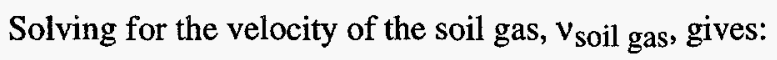




$$
v_{\text {soil gas, advective }} \geq \frac{\frac{\mathrm{D} \cdot \mathrm{C}_{0}}{\sqrt{\pi \mathrm{Dt}}} e^{\left(-\frac{\mathrm{x}^{2}}{2 \mathrm{Dt}}\right)}}{\mathrm{C}_{\mathrm{o}}+\left\{1-\operatorname{erf}\left(\frac{\mathrm{x}}{2 \sqrt{\mathrm{Dt}}}\right)\right\}}
$$

Any advective soil gas velocity in the upward direction equal to or greater than that calculated using Equation 12 will keep contaminants from diffusing deeper into the vadose zone.

This model was applied to the diffusion of TCE from a planar source, using an initial source concentration calculated with the contaminant's vapor pressure. It is important to note that this is an absolute maximum value for $\mathrm{C}_{0}$ at ambient pressure and temperature, and the calculated results are thus conservative. The results are shown in Figure 7, where the concentration, mass flux, and minimum advective velocity required to overcome the diffusive transport rate are plotted as a function of vertical distance down from the contaminant source. The planar source requires advective velocities ranging from $2 \times 10^{-7}$ to $7 \times 10^{-7} \mathrm{~m} / \mathrm{s}(0.017$ to $0.060 \mathrm{~m} /$ day $)$ to overcome the downward diffusion transport rate from a saturated source.
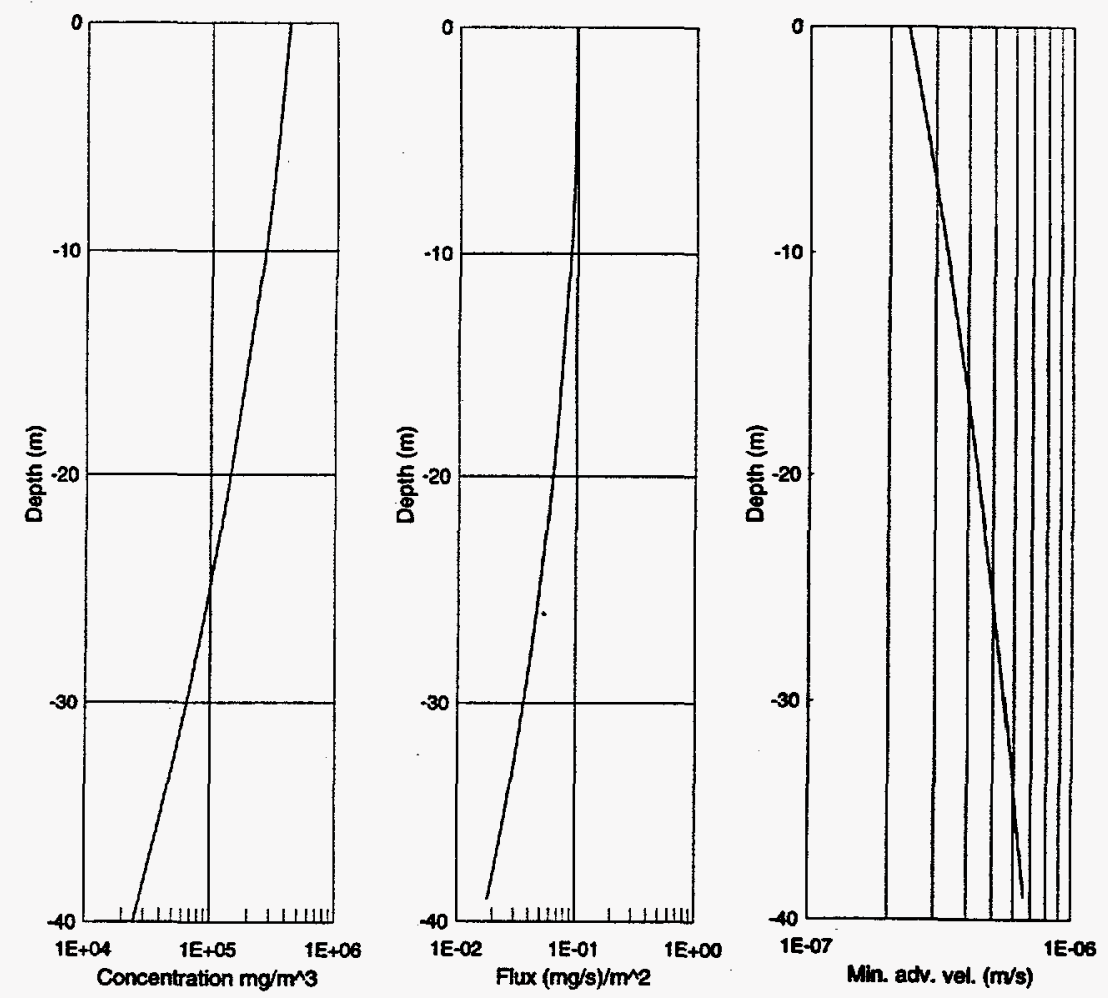

Figure 7. Concentration profile, mass flux, and minimum advective velocity required to overcome contaminant mass flux of TCE evaporating from a planar one dimensional source (at steady state). 


\subsection{Density Induced Transport of Volatile Contaminants}

Besides the diffusion of contaminants in soil gas, density effects can drive vapors toward the water table. The net upward soil gas velocities caused by the surface treatment system must also counteract these forces. Density effects are induced by temperature and contaminant concentration gradients in the soil gas.

\section{Temperature induced density gradients}

The meteorologic data summarized in Appendix A included the seasonal variability of air temperature at the different sites. The cooled soil surface in the winter will tend to drive soil gas downward; the heated soil surface will pull air up out of the soil. The seasonal variation can be simulated as a sine wave for a yearly period, and its impact on the soil temperature modeled with transient thermal analysis techniques. This was done in Appendix $\mathrm{C}$, using typical thermal properties of soil and a total temperature variation of $24 \mathrm{C}$ over a yearly cycle. The impact on the soil gas density is small due to these changes. The minimum advective flow required to overcome the buoyancy effects is calculated by determining the effective pressure gradient caused by the temperature distribution. The advective flow, given the permeability of the soil, required to overcome this induced pressure gradient is calculated. This is the minimum advective flowrate which will overpower the density induced soil gas flow. The calculations in Appendix $\mathrm{C}$ indicate that at most $3 \times 10^{-7} \mathrm{~m} / \mathrm{s}(0.026 \mathrm{~m} /$ day $)$ is required. The required velocity drops rapidly with depth, where at 2 to 4 meters below the surface the required velocity is only $1 \times 10^{-7} \mathrm{~m} / \mathrm{s}(0.009 \mathrm{~m} / \mathrm{day})$. As will be shown in the subsequent section, the advective velocities imposed by the barometric pumping system are much higher than this.

\section{Concentration induced density gradients}

Since most contaminant vapors are more dense than air, concentration gradients, which will naturally exist in the soil (described in Section 2.3 and Appendix B), will induce downward contaminant transport below the contaminant source. The concentration induced density profiles can be analyzed in similar fashion to the thermally induced density gradients in the previous discussion (the details of this are in Appendix D). Once the contaminant concentrations are known from the diffusion calculations, the density of the soil gas mixture is calculated. An equivalent pressure gradient in the soil is then determined, and an advective flux is calculated (given the soil permeability) which will overcome the density induced pressure gradient.

This was calculated for TCE evaporating and diffusing downward from a planar source. TCE has a molecular weight of $131.4 \mathrm{gm} / \mathrm{gm}$ mole (the molecular weight of air is $29 \mathrm{gm} / \mathrm{gm}$ mole). The calculation showed that immediately beneath the source the advective flux required to overcome the density gradient is $0.7 \times 10^{-6} \mathrm{~m} / \mathrm{s}$ $(0.06 \mathrm{~m} / \mathrm{day})$. At 5 meters below the source the required advective velocity is approximately half that. These numbers are on the order of the velocity predicted in the following section, and also similar in magnitude to the velocities required to overcome diffusive transport. Again, the initial source concentration of the contaminant was 
calculated using the contaminant's vapor pressure (e.g., the factors which would decrease this value were ignored.) Thus the calculated concentration profiles, and the resulting velocities, are worst case conditions.

These naturally occurring flow and transport processes are summarized and compared to the net velocities resulting from the surface treatment system in the next section, which includes a numerical transient analysis of a typical installation. 


\section{SECTION 3.0}

\section{ENGINEERING THE REMEDIATION SYSTEM}

\subsection{Design Features}

In its installed form, the typical barometric remediation system is depicted in Figure 8. The four key components are the surface seal, the plenum, the vent assembly, and the soil vapor monitoring points.

\section{$\underline{\text { Surface seal }}$}

The role of the surface seal material is to contain soil vapors in the plenum region and prevent flow into or out of the soil in the buffer zone. Seal material must be resistant to soil moisture, organic contaminants, and sunlight (if exposed), and capable of multiyear emplacements. Fortunately, geomembranes have been developed for landfill installations to fill requirements more stringent than these, so a wide selection of candidate materials is available. The two most common landfill cover and liner materials are high density polyethylene and EPDM (synthetic rubber). Polyethylene is available in a range of thicknesses (up to $40 \mathrm{mil}$ ) and is readily joined to form large sheets. Typical costs for large square sheets $(100 \times 100 \mathrm{ft})$ range from $\$ 0.12$ to $\$ 0.20 / \mathrm{ft}^{2}$. EPDM, originally developed as a roofing material, is more rugged and resistant to exposure, but costs two to three times as much as polyethylene (in 45 mil thicknesses, $\$ 0.45$ to $\$ 0.70 / \mathrm{ft}^{2}$ ).

\section{Typical Installation}

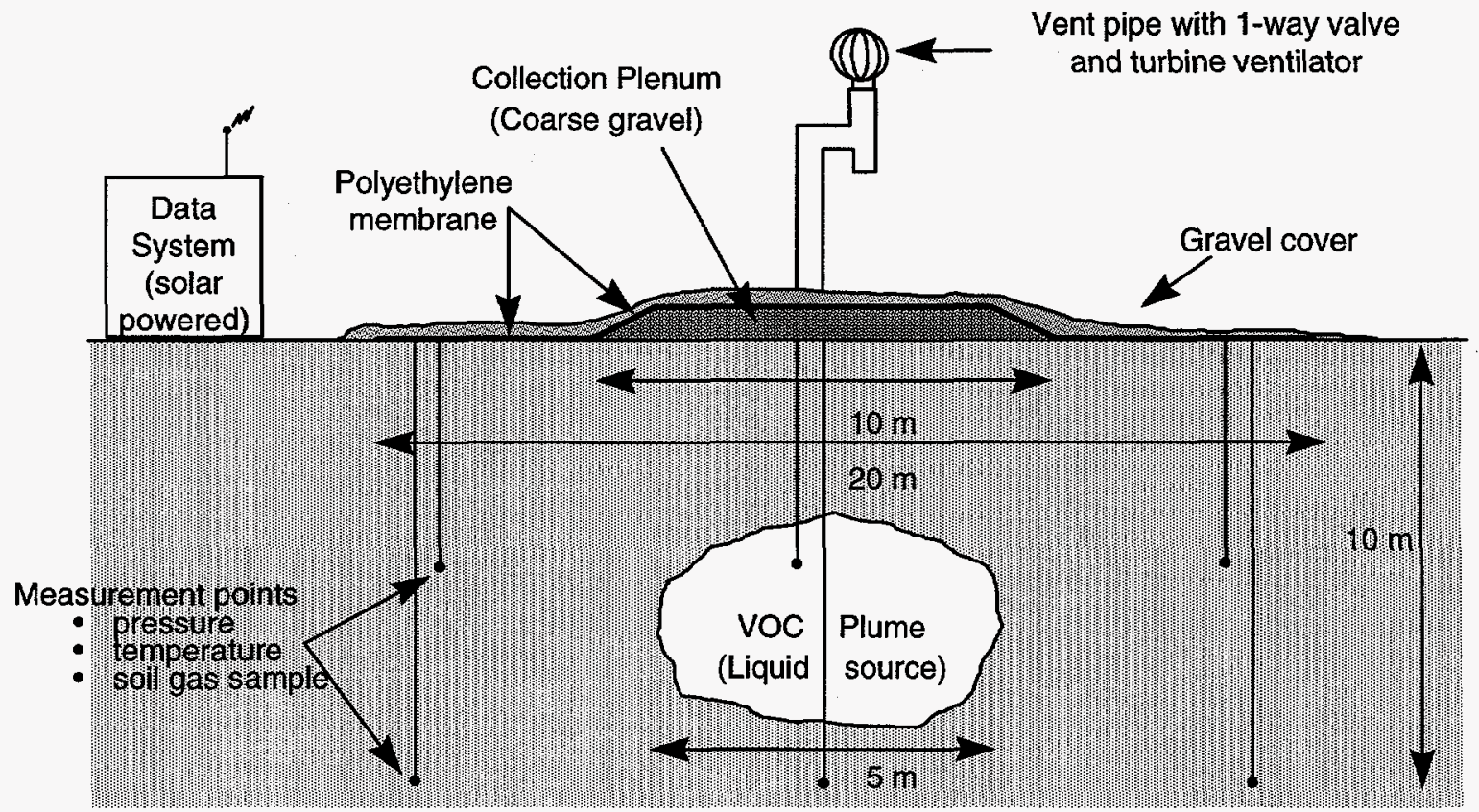

Figure 8. Typical field installation of barometric remediation system. 
For simplicity and leak-tightness, the surface seal is one continuous sheet covering both the buffer zone and the plenum volume. It must be pliable enough to conform to the contours of the soil (the soil will be leveled to some degree before the seal is applied) and over the plenum. Around the perimeter of the surface seal, a shallow trench ( $1 \mathrm{ft}$ by $1 \mathrm{ft}$ ) will have been formed prior to emplacement to anchor the edges of the geomembrane material. To minimize damage to the geomembrane from abrasion (due to foot traffic), exposure to the elements, or plant/animal intrusion, a shallow layer of gravel ( 3 to 6 in thick) is placed over the membrane. This serves a secondary role of assuring the membrane is pressed firmly onto the soil to effect a good seal.

\section{$\underline{\text { Plenum }}$}

The plenum serves as a collection manifold for the upward-flowing soil gas during the exhaling cycle of the system. Its basic requirements is that the plenum material have a permeability several orders of magnitude greater than the soil below. It must also be inexpensive, stable, and not pose a puncture threat to the membrane material (no sharp edges). Standard pea gravel (not crushed) fills these requirements with permeability in the range of 100 to 1000 Darcies. Since it has such a high permeability, its thickness does not have to be great: six to twelve inches is adequate. This same material can also serve as the protective layer over the sealing membrane.

Vent assembly

The main role of the vent assembly is to allow only outward (exhaling) flow from the plenum volume. Its secondary role is to release the soil vapor high enough into the air to rapidly disperse the contaminants. The assembly consists of a vent pipe, a flapper valve, and a turbine ventilator. The surface seal membrane is clamped securely around the base of the vent pipe, which is free standing. The valve is a very low differential pressure relief valve, designed to release soil gas at overpressures less than 0.1 mbar and provide very little backpressure when open. The turbine ventilator is an enhancement which capitalizes upon the surface winds to increase the extraction vacuum in the plenum. The vent valve is designed to operate at a minimal differential pressure while maintaining a seal when no pressure differential exists allowing for flow in one direction. The approach to the design is to mount a light weight flapper valve inside the stack vent that will provide a seal by resting its mass on a sealing surface (Figure 9). The valve design is basically a lightweight frame upon which is mounted a sheet of mylar or similar material. The valve is oriented at an angle off of vertical in the vent pipe. The mounting angle is selected to open at a specified differential pressure, selected to be the minimum pressure difference expected to exist between the plenum and the soil outside the buffer zone. Figure 10 shows the required pressure differential to open the valve as a function of mounting angle of a 0.004 in thick sheet of mylar. Note that the valve can be designed to open at pressures lower than 0.01 mbar. This design will be optimized to assure that the valve does not open prematurely, and allows sufficient overpressure to build up within the plenum to maintain stable outflow. 


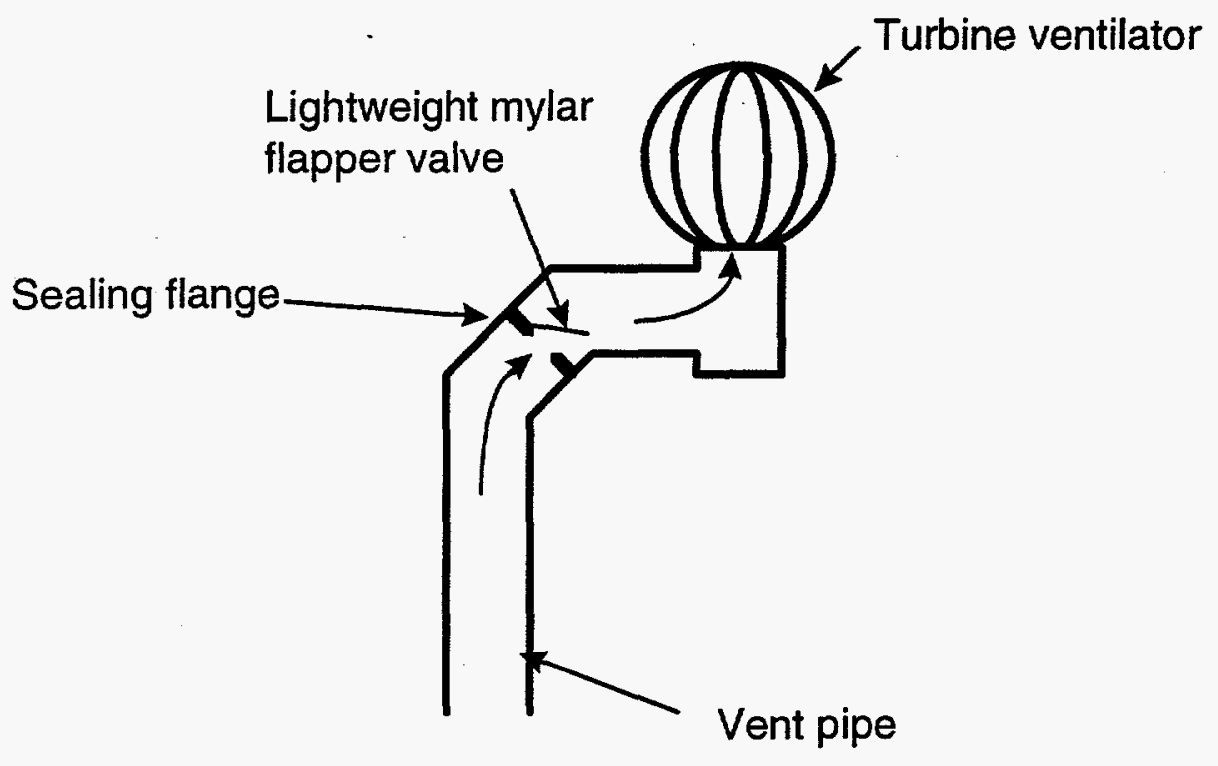

Figure 9. Relief (flapper) valve configuration

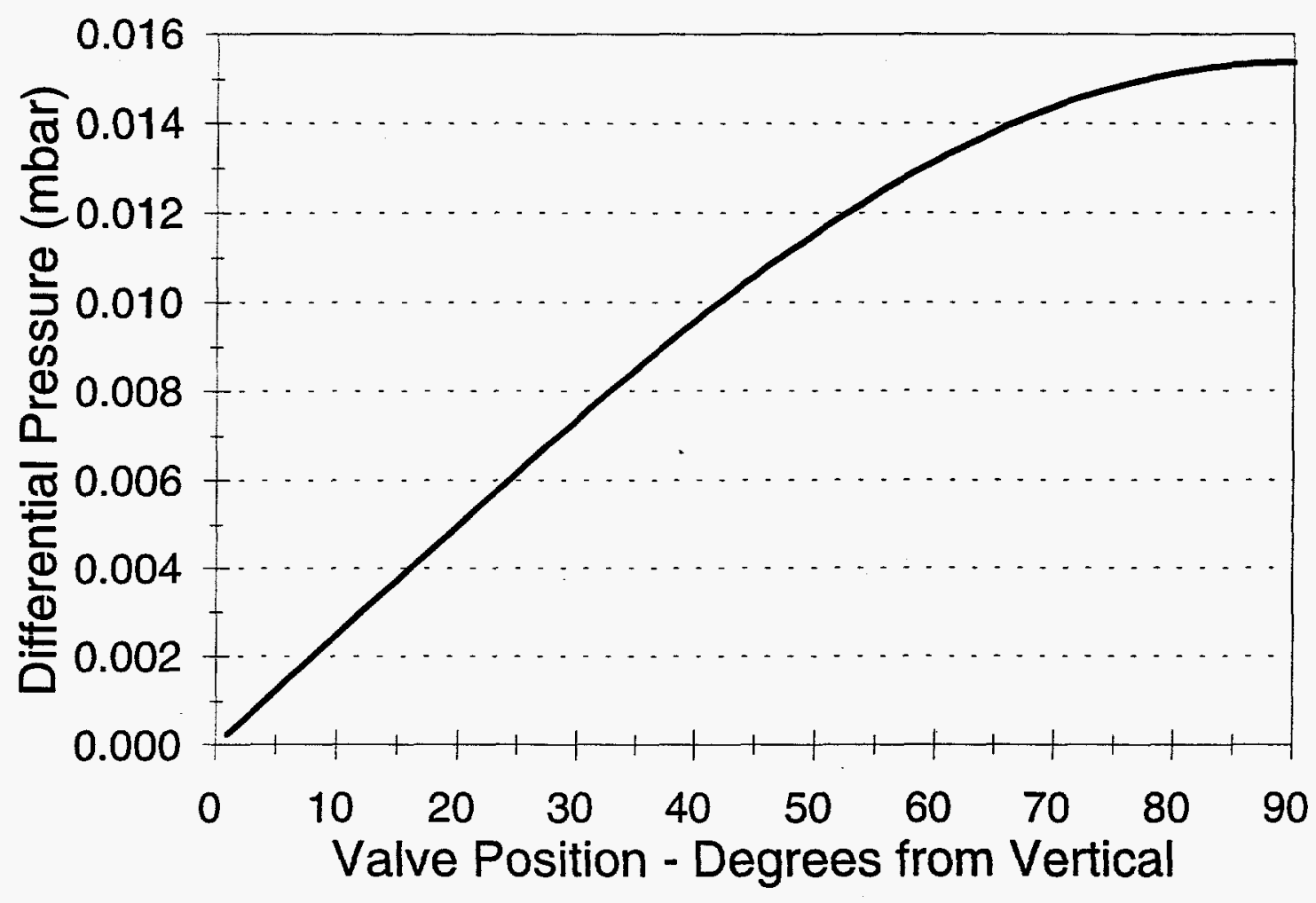

Figure 10. Pressure required to open a vent valve with a 0.004 in thick mylar element. 


\section{Soil vapor monitoring points}

The performance of this remediation and containment system will be monitored through the use of soil vapor sampling points emplaced in and around the contaminant plume (Figure 8). Prior to surface seal emplacement, the vapor sampling points would be installed. This would be accomplished using hand emplacement tools for shallow points (such as the KVA Analytical vapor point system) or hydraulic emplacement systems (such as the Geoprobe system) for deeper points. The tubing for these sample points would be routed under the surface seal to its outer perimeter, where they are accessed for sampling.

Once the vapor points are installed, and before the surface sealant is emplaced, a baseline soil vapor survey is conducted to establish the data set against which the monitoring results will be compared. After the surface system is fully emplaced and operational, vapor monitoring could occur on a quarterly or semi-annual frequency to assess the overall performance of the system. The extent (and expanse) of soil gas analysis is dependent upon the nature and complexity of the contaminant source. If the source is of a single contaminant, then the gas analysis could be accomplished with a field flame ionization detector (FID) or (PID) instrument. For more complicated sources, photoionization detector field gas chromatographs (CG) or photoacoustic analyzers may be required. In the most complex cases laboratory GC analysis may be appropriate. 


\subsection{Predicted Performance}

The role of this system design is to rectify, or minimize the downward sinusoidal component of the oscillatory soil gas movement as much as possible, to maximize the net upward velocity in the contaminated zone. The range of peak soil gas velocities attainable due to the naturally occuring variations in barometric pressure was identified in Section 2.2 (see Figure 6). The maximum surface gas flux can be determined from the peak velocity plot by averaging the upward portion of the oscillatory velocity over a daily cycle. This is done by assuming that the velocity history is sinusoidal and we are only interested in the half of the sinusoid which results in positive upward flow (the one way vent valve prevents downward flow, hence resulting in a rectified flow out of the surface). Multiplying the peak velocity by $1 / \pi$ yields the average velocity of the rectified sine wave over the entire period. Soil gas velocity is converted to flux by multiplying by the soil's connected, gas-filled porosity. This is done to the data plotted in Figure 6, and is presented in Figure 11. The maximum net soil gas flux attainable with the surface treatment system ranges from 0.03 to $0.07 \mathrm{~m}^{3} / \mathrm{m}^{2} /$ day for 1 to 10 Darcy soil, with depths to the impermeable layer exceeding $30 \mathrm{~m}$. For a $10 \mathrm{~m}$ diameter plenum, this yields a total soil gas extraction flowrate of 2.3 to $5.5 \mathrm{~m}^{3} /$ day. Given an air filled porosity of $0.35,6.6$ to $15.7 \mathrm{~m}^{3}$ of soil is flushed per day.

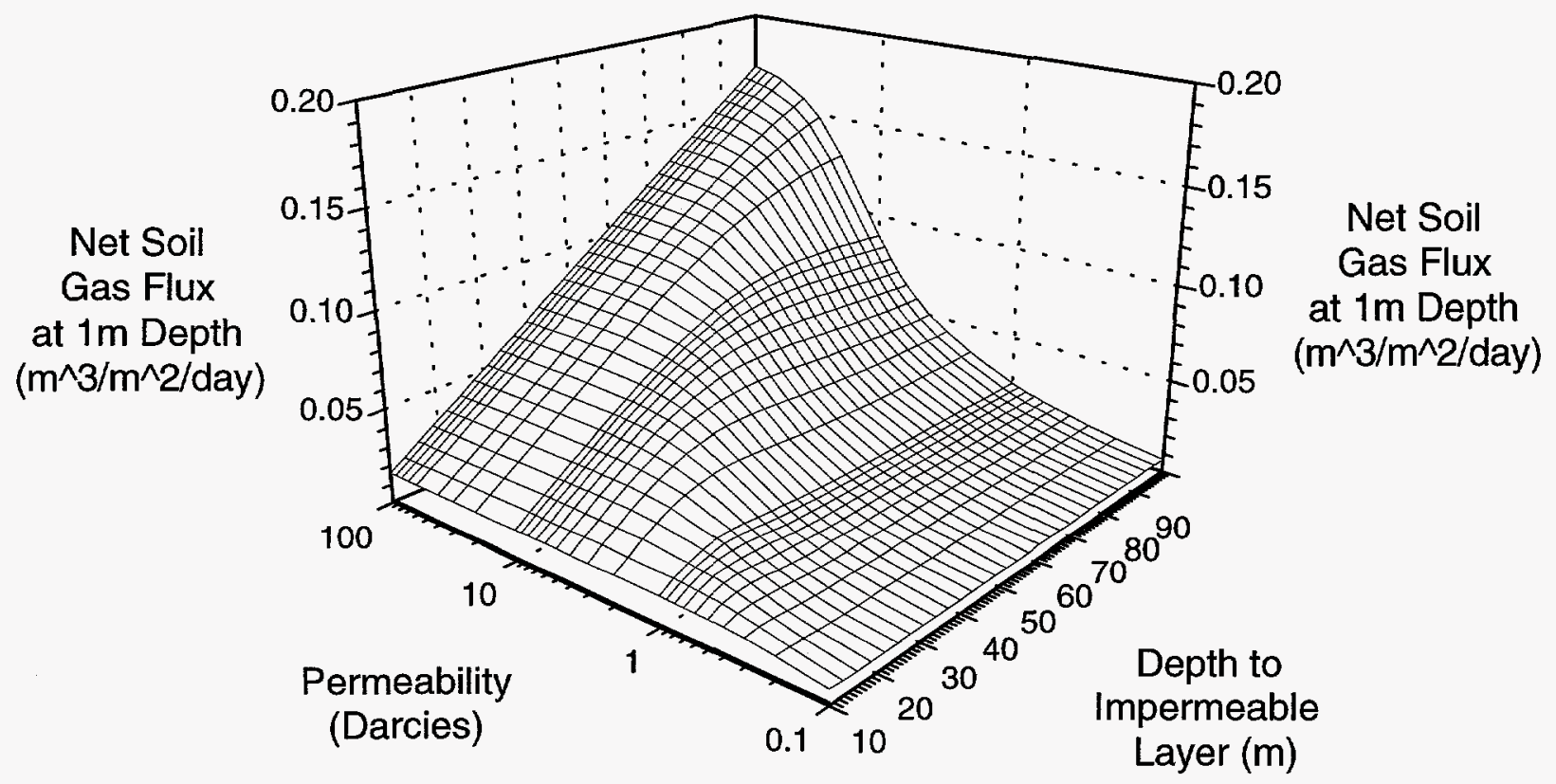

Figure 11. Maximum net upward soil gas flux attainable by the surface treatment system, given daily barometric pressure oscillations of $5 \mathrm{mbar}$ and a soil porosity of 0.35 . 
Ideally, the surface treatment system results in a soil gas flux near the surface that is of a net magnitude equal to the upward-only component in the free field. This is attainable at the soil surface in the plenum zone. However, the gas is not constrained to flow only vertically in the soil, so the degree of rectification diminishes with depth.

To determine the depth of influence of the surface treatment on soil gas flow, a transient numerical simulation was conducted with the Los Alamos National Laboratory FEHM code (Finite Element $\underline{\text { Heat }}$ and Mass transfer).

FEHM is capable of modeling multiphase heat and mass transport in porous media [References 2,3, and 4]. For this effort, gas flow only is modeled with an oscillatory surface pressure, a collection plenum connected to the atmosphere through a one way relief valve, an impermeable surface seal, an impermeable layer forming the model's bottom boundary, and a radial symmetric geometry. The geometry and properties are depicted in Figure 12 . Atmospheric pressure is sinusoidal, with a period of 24 hours and a total variation of 5 mbar. The relief valve is modeled by allowing the plenum volume to have direct communication to the atmosphere when the gradient causes upward flow; the valve is closed at all other times. The soil permeability is set at 5 Darcies, and its air-filled porosity is 0.35 (these are typical properties of alluvial deposits). The depth to the impermeable layer is $100 \mathrm{~m}$.

Velocity vectors at the two maximum flow times during the periodic cycle are depicted in Figure 13. Note that, as the barometric pressure drops, upward air flow occurs beneath the plenum at the same velocity as it does in the free field (away from the effects of the surface seal). Decreased vertical flow occurs beneath the buffer zone. As the barometric pressure rises, normal downward flow occurs in the free field but the scaled vectors indicate almost no downward vertical flow beneath the plenum (the vent valve is closed during this part ot the cycle). It is this restricted downward flow that causes the net upward air flow over time.

The net (average) upward soil gas velocity is the main parameter of interest when comparing the advective velocities against the downward transport rates. For the 24 hour cycle modeled in the simulation, the velocities were averaged over the period to obtain a net vertical velocity distribution in the soil. This is shown in Figure 14 as bar graphs of net velocity at depths of $0,1,5$, and 10 meters. Below the plenum region, the velocity is always positive (up). Near the outer edge of the plenum, at the ground surface, the upward velocity is of a greater magnitude than in the center of the plenum. A slightly negative (downward) velocity also exists just beyond the buffer zone. Both of these are due to the acceleration which will occur near a flow restriction (such as that which occurs near the edge of an orifice plate in a flowing stream).

The average vertical flow along the centerline of the plenum is plotted in Figure 15. At the surface inside the plenum region the average velocity is $0.2 \mathrm{~m} /$ day, meaning that 0.2 meters of soil gas is ratcheted up daily. This is converted to a gas flux by multiplying by the soil porosity $(0.35)$, resulting in a surface flux of $0.2 \mathrm{~m} /$ day $\times 0.35=$ $0.07 \mathrm{~m}^{3} / \mathrm{m}^{2} /$ day. Note that this is equal to the flux predicted with the analytic model (see Figure 11) for similar 


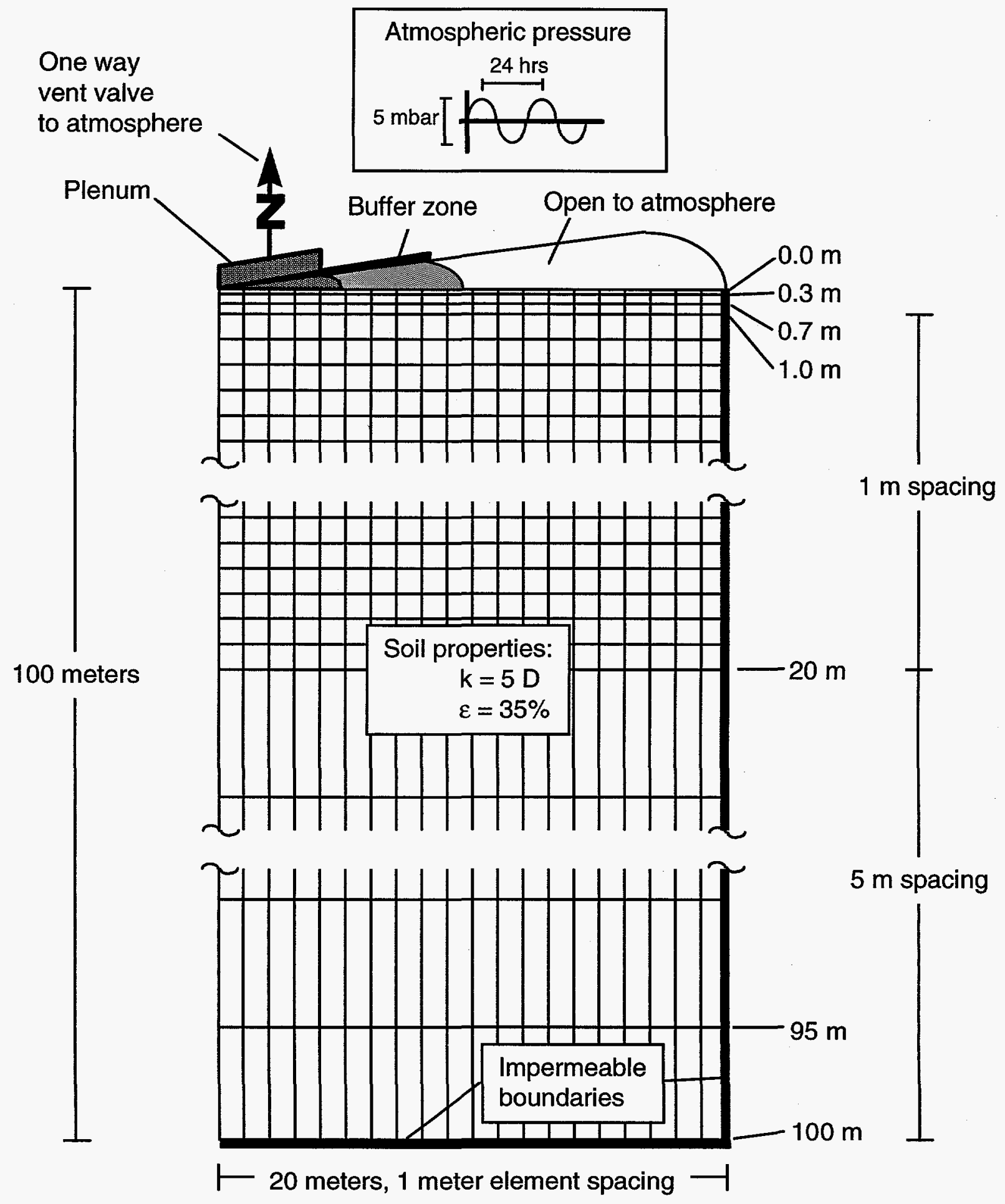

Figure 12. Geometry and properties simulated in the FEHM calculation 


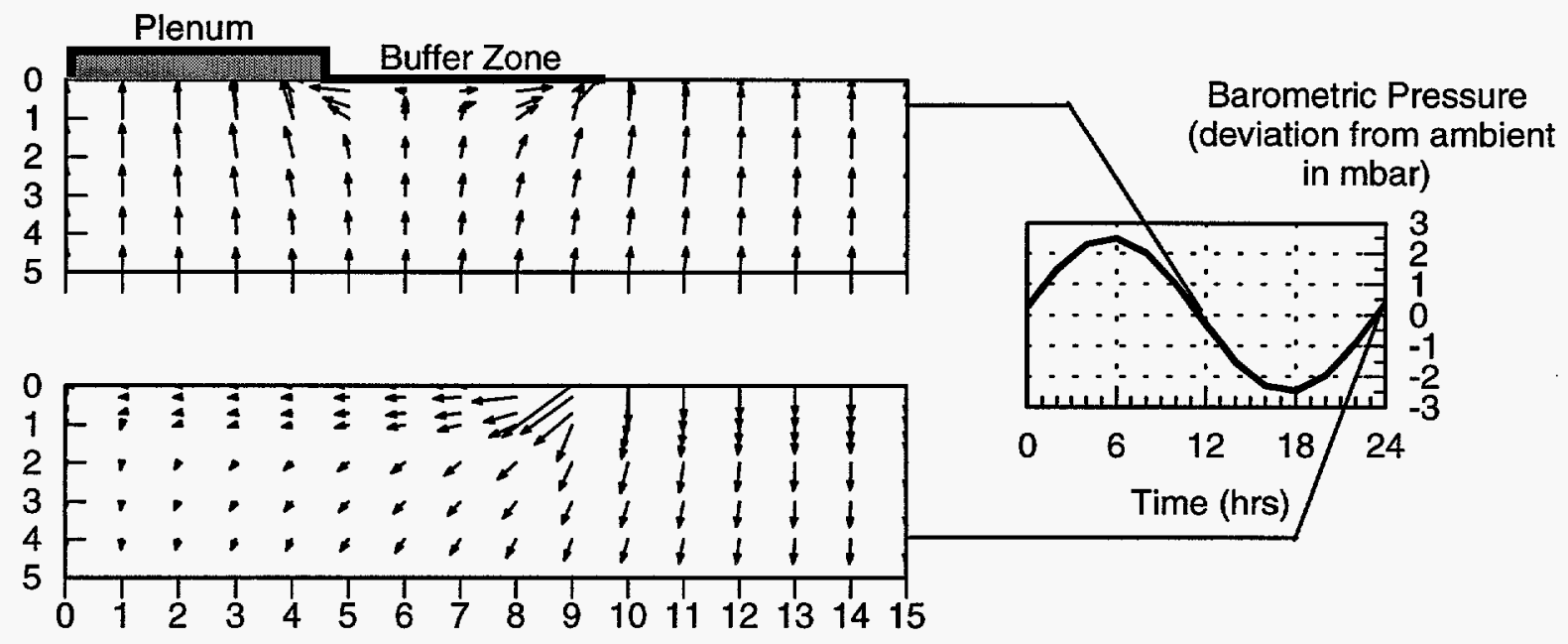

Radial Distance from Plenum Center (m)

Figure 13. Resulting velocity fields due to the surface treatment.

conditions. The surface treatment effectively reduces to zero the downward flow immediately beneath the plenum, but allows unobstructed upward flow during the exhaling cycle.

The net velocity profile resulting from the numerical simulation is compared with the advective fluxes required to overcome the transport processes due to diffusion and density induced flow. These processes were discussed in Sections 2.3 and 2.4 and their magnitudes estimated. Each will be compared below.

\section{Diffusion}

In the case of TCE evaporating and diffusing away from a one dimensional planar source, an advective upward velocity of $2 \times 10^{-7} \mathrm{~m} / \mathrm{s}(0.017 \mathrm{~m} /$ day $)$ will overcome the diffusion rate at the source. Referring to Figure 15 , the net upward velocity is above this value down to a depth of $10 \mathrm{~m}$. This means that the surface treatment system, as modelled in this section, would effectively counter the diffusive transport of a liquid TCE source from the $10 \mathrm{~m}$ depth. 

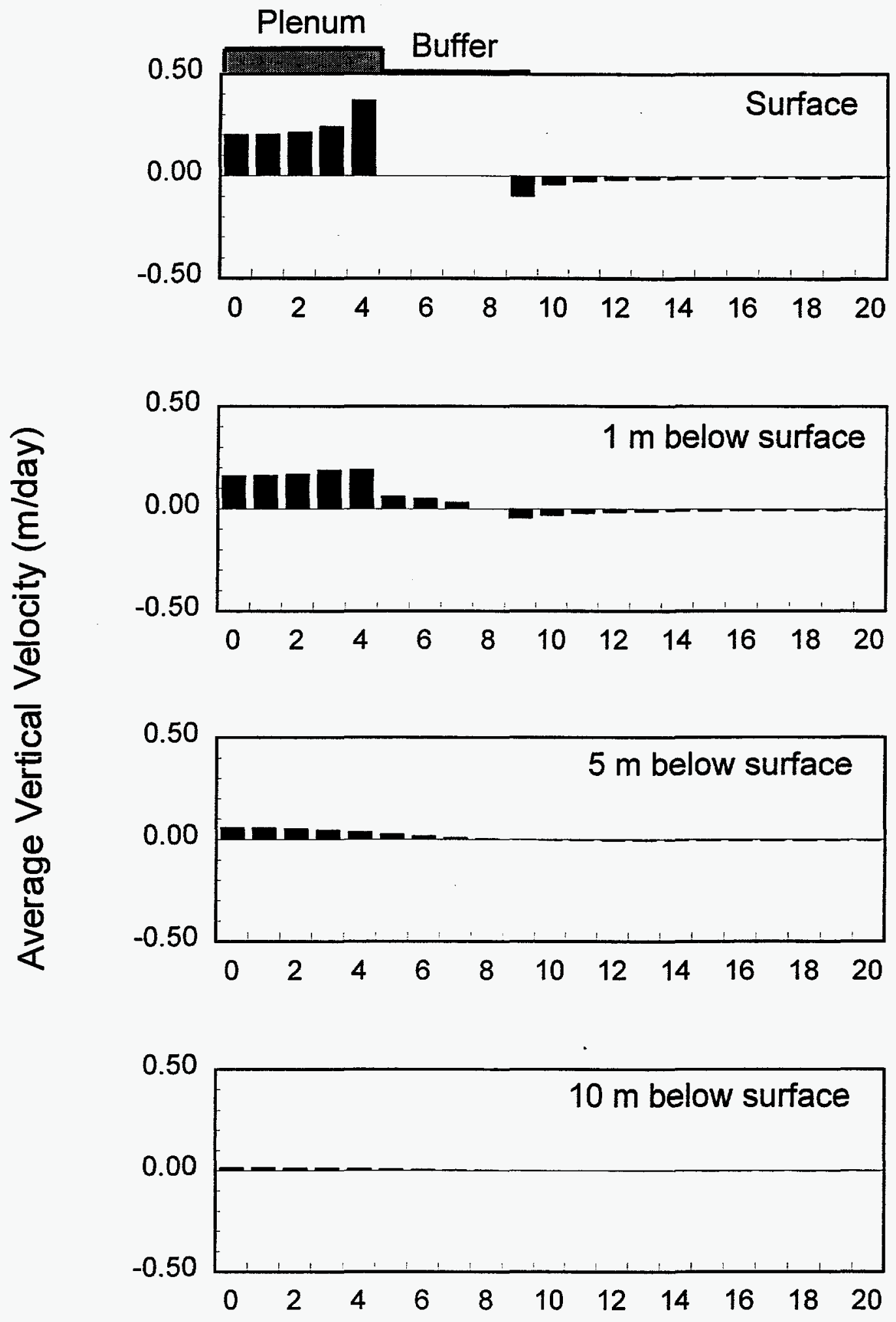

Radial Distance from Plenum Center $(\mathrm{m})$

Figure 14. Net resulting soil gas velocities at depths of $0,1,5$, and 10 meters due to surface treatment. 


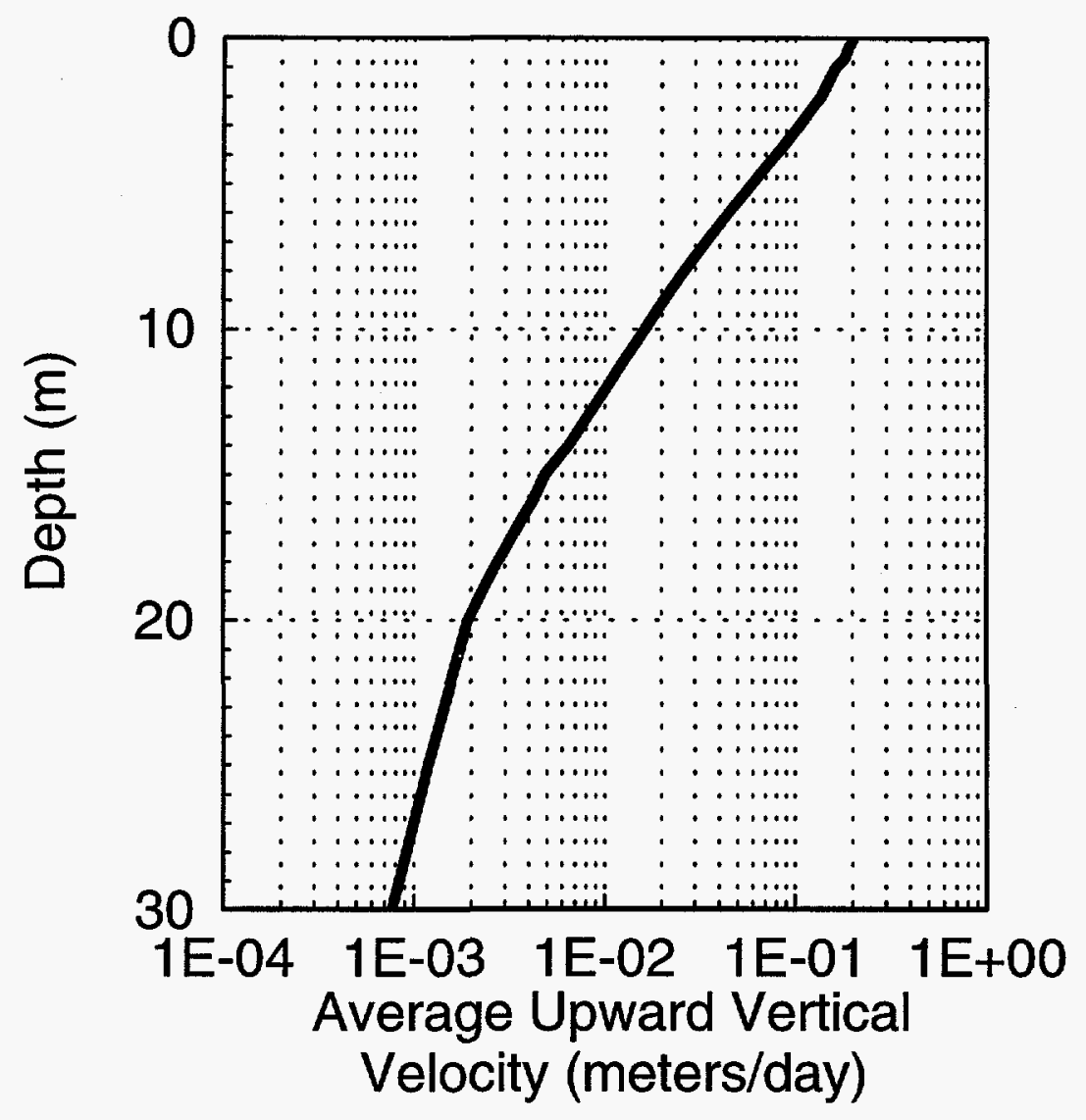

Figure 15. Net vertical velocity profile resulting from surface treatment.

\section{Temperature induced density gradients}

Temperature induced gradients cause both upward and downward soil gas movement. However, their effects are small compared to the other processes considered. Considering normal variations of seasonal temperature in Albuquerque, for example, the density gradients resulting from cooling of the surface soil required advective upward velocities ranging from $3 \times 10^{-7} \mathrm{~m} / \mathrm{s}(0.026 \mathrm{~m} /$ day $)$ at the soil surface. At a depth of $4 \mathrm{~m}$, this drops to $1 \times 10^{-7} \mathrm{~m} / \mathrm{s}$ $(0.009 \mathrm{~m} /$ day $)$. The net velocity plot in Figure 15 shows $0.2 \mathrm{~m} /$ day at the surface and $0.08 \mathrm{~m} /$ day at $4 \mathrm{~m}$. The temperature induced density gradients are insignificant under these conditions.

\section{Concentration induced density gradients}

Since the density of TCE is 4.5 times the density of air, as it evaporates from a liquid source it results in a gas mixture that will tend to sink. This tendency will be greatest near the source and diminish with distance. The analysis of Section 2.4 showed that near a planar TCE source the diffusion will result in a concentration gradient (hence a density gradient) that requires advective velocities as high as $7 \times 10^{-7} \mathrm{~m} / \mathrm{s}(0.06 \mathrm{~m} / \mathrm{day})$. At a distance of $4 \mathrm{~m}$ below the TCE source, the required advective flowrate is $5 \times 10^{-7} \mathrm{~m} / \mathrm{s}(0.04 \mathrm{~m} /$ day $)$. Comparing this to the net upward 
flows in Figure 15, we see that the surface treatment system overcomes this downward transport for a source buried as deep as $4 \mathrm{~m}$ in the soil.

\section{Performance summary}

The surface treatment system is capable of controlling the soil gas flows, with a maximum effect at the soil surface in the plenum region. Key performance features of the system are as follows:

- The extraction flux, under typical conditions, ranges from 0.03 to $0.07 \mathrm{~m}^{3} / \mathrm{m}^{2} /$ day. For a $10 \mathrm{~m}$ diameter plenum, this yields a total soil gas extraction flowrate of 2.3 to $5.5 \mathrm{~m}^{3} /$ day.

- The depth of influence of the system is defined by the maximum depth at which it can overcome the other downward transport processes. The system can induce a net upward flow to counteract the concentration induced density gradient to a depth of $4 \mathrm{~m}$. This is the most difficult process to overcome. Diffusion from a TCE source can be overcome with a source as deep as $10 \mathrm{~m}$. Temperature induced density effects are not significant and can be overcome in all cases.

- The maximum contaminant removal rate is defined by how readily the source compounds volatilize and diffuse away from the source, given that the system can sweep all the contaminated vapors upward from a source. The maximum TCE transport rate from a planar source is $0.1 \mathrm{mg} / \mathrm{s}-\mathrm{m}^{2}$. If the source is $5 \mathrm{~m}$ in diameter and the TCE diffuses from both the top and bottom of the source, this translates to a daily removal rate of $0.34 \mathrm{~kg}$, or $124 \mathrm{~kg} /$ year.

\subsection{Design Guidelines}

The two parameters requried to optimize the design of this system, given the general location and nature of the contaminant source, are the plenum diameter and extent of the buffer zone.

\section{Plenum diameter}

Since the contaminant will be diffusing laterally outward from the source, the plenum needs to be sized to assure that these contaminants are captured and transported upward during the exhaling process. The diffusive transport rate drops off rapidly with radial distance. The plenum should be larger in.radius than the source (the source being defined as the liquid deposit of the contaminant) to ensure capture of the volatilized contaminants diffusing laterally. A rough guide would be a plenum diameter twice the size of the source. Further work is required to refine this.

\section{Extent of the buffer zone}

The buffer zone effects the depth of influence of the surface treatment. It also resists rapid lateral inflow through the near surface soil to the plenum during the inhalation cycle. Wider buffer zones increase the depth of influence, but also increase installation cost roughly as a square of the outer radius of the buffer. An initial guide is to design the buffer zone outer radius to be twice the radius of the collection plenum, although further analysis is warranted to refine this also. 


\subsection{Enhancements}

Two features were considered for inclusion in the extraction system design because of their relatively low implementation cost versus the potential increase in extraction system performance. One is the use of a turbine ventilator to capitalize on the natural surface winds to increase the plenum vacuum. The other is use of a clear cover over the plenum region to heat the extracted air with solar radiation, enhancing the extraction vacuum with a chimney effect. Calculations and tests proved the turbine will significantly enhance the system while solar heating will not. A summary of each enhancement option follows.

\section{Turbine ventilator}

It is logical to capitalize on wind to enhance the performance of the barometric pumping system because wind speeds typically peak in the afternoon and early evening of the day, which is also the time when the earth is exhaling the most due to drops in barometric pressure. The same atmospheric temperature rise that drops barometric pressure also results in increased wind speeds.

Turbine ventilators are inexpensive devices used to increase circulation in large open volumes such as attics and warehouses. They are usually located on the top of a roof so they are exposed to winds, which induces drag on the vanes and cause them to rotate. The vanes are shaped such that when they are rotating, they pull air up out of the ventilated volume below. A 12-in. diameter turbine vent is capable of flowing $17 \mathrm{~m}^{3} / \mathrm{min}$ free air $(600 \mathrm{cfm})$ with a wind speed of $1.8 \mathrm{~m} / \mathrm{s}(4 \mathrm{mph})$, and costs less than $\$ 50.00$.

The turbine would be placed on the outlet end of the vent pipe (see Figure 16). Since drawing air out of the ground results in far more resistance to flow than is normally experienced in building ventilation, the ventilator will not be able to move as much air as specified for its normal applications. It will, however, be capable of imposing a vacuum on the plenum to enhance the extraction rate. To determine the peak vacuum attainable with a turbine ventilator, a standard 12-in. industrial turbine vent (externally braced) was acquired and tested. Its bottom inlet was blocked off and the vanes were exposed to air flowing at different velocities, which were measured with a pitot tube air velocity sensor. The test showed that at air velocities ranging from 7 to $12 \mathrm{~m} / \mathrm{s}$ ( 17 to $30 \mathrm{mph}$ ) the ventilator generated a vacuum of 0.5 to 0.9 mbar. While this is not a high vacuum when compared to other types of fans (the turbine ventilator is designed for maximum flow, not maximum vacuum) this imposed vacuum in the plenum will result in a significant enhancement in the extraction rate. Natural pressure gradients in the soil beneath the surface due to the barometric pressure oscillations are on the order of $0.02 \mathrm{mbar} / \mathrm{m}$ (see figure 5 and Appendix E). Adding a vacuum of 0.5 mbar immediately at the surface can result in at least an order of magnitude greater outflow at the surface during peak wind speeds (see Appendix A). This increased flow is achieved at a very low cost. 
The turbine vent is depicted in Figure 9 as being mounted upside down. This configuration prevents rain from falling into the vent pipe and inhibiting the operation of the vent valve.

\section{Solar heating of the plenum gases to enhance outflow}

Heating the soil gas collected inside the plenum will reduce its density and induce an upward buoyancy force as that which occurs in chimneys. To determine whether this results in a sufficient increase to warrant the added cost of a clear plenum cover, a simple configuration was evaluated. Figure 13 shows the layout of the system. A black absorbing surface, slightly smaller in diameter than the plenum diameter, is placed slightly above ground level and is used as the solar collector. The plenum is fabricated of $6.4 \mathrm{~mm}(0.25 \mathrm{in})$ thick glass. A vent stack is placed on the plenum and is designed such that rain or debris cannot enter through the stack vent.

In order to determine the buoyancy effect created by the increased air temperature in the plenum, a rough determination of the maximum attainable air temperature in the plenum is required. For the purpose of considering worst case solar conditions, the months of November through March were evaluated.

The average insolation value for the months of November through March, at a latitude of 38 degrees, is $1502 \mathrm{BTU} / \mathrm{ft}^{2} \mathrm{iday}$ which equates to $197.41 \mathrm{Watts}(\mathrm{W}) / \mathrm{m}^{2}$. Given the average angle of incidence of the sun relative to the horizontal glass surface of the plenum and the transmissive properties of the glass, a transmission of 40 percent of the average insolation value is used as the amount of energy incident on the black absorbing surface. Assuming that the material has an absorbtivity of 90 percent, the total amount of energy entering the system is $71.07 \mathrm{~W} / \mathrm{m}^{2}$. The means of energy transfer are: the convective heat losses from the outside surface of the plenum to the ambient air outside, the conduction heat loss through the glass of the plenum, the convective heat loss from the absorbing surface to the air inside the plenum, and the convective heat loss of the air inside to the soil directly underneath the absorbing surface. The radiation heat loss from the absorbing surface is considered to have a minimal effect on the overall heat transfer and is not considered in the calculation. The following list identifies the variables for the calculation, which assumes steady state thermal conditions and no significant air flow out of the plenum:

Qin - Energy entering the system from insolation $=71.07 \mathrm{~W} / \mathrm{m}^{2}$.

Qconv,O - Convective heat transfer outside plenum.

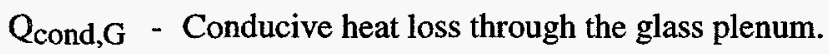

Qconv,I - Convection heat transfer from absorbing surface to inside plenum surface.

Qcond,S - Conductive heat loss through the soil.

$\mathrm{T}_{\mathrm{s}} \quad-$ Absorbing surface temperature $(\mathrm{K})$. 
$\mathrm{T}_{\mathrm{s} 1} \quad$ - Constant soil temperature at three meters ( $\left.288 \mathrm{~K}\right)$.

$\mathrm{T}_{\mathrm{g}} \quad$ - Inside surface temperature of glass plenum.

$h_{o} \quad-$ Convective heat transfer coefficient outside plenum $\left(15 \mathrm{~W} / \mathrm{m}^{2} \mathrm{~K}\right)$.

$\mathbf{h}_{\mathrm{i}}$ - Convective heat transfer coefficient inside plenum $\left(5 \mathrm{~W} / \mathrm{m}^{2} \mathrm{~K}\right)$.

$\mathrm{k}_{\mathrm{g}} \quad$ - Thermal conductivity of glass plenum ( $\left.1.25 \mathrm{~W} / \mathrm{m} \mathrm{K}\right)$.

$\mathrm{k}_{\mathrm{s}} \quad$ - Thermal conductivity of the soil $(0.52 \mathrm{~W} / \mathrm{m} \mathrm{K})$.

t $\quad-$ Thickness of glass $(0.0063 \mathrm{~m})$

Total heat leaving the plenum is:

$$
\begin{aligned}
& Q_{\text {out }}=\mathrm{Q}_{\text {conv }, \mathrm{O}}+\mathrm{Q}_{\text {cond }, \mathrm{G}}+\mathrm{Q}_{\text {conv }, \mathrm{I}}+\mathrm{Q}_{\text {cond }, \mathrm{S}} \\
& \mathrm{Q}_{\text {conv }, \mathrm{O}}+\mathrm{Q}_{\text {cond, }, \mathrm{G}}+\mathrm{Q}_{\text {conv }, \mathrm{I}}=\left(\mathrm{T}_{\mathrm{S}}-\mathrm{T}_{\mathrm{O}}\right) / \mathrm{U}_{1}
\end{aligned}
$$

where $\mathrm{U} 1$ is

$$
\mathrm{U}_{1}=\left(1 / \mathrm{h}_{\mathrm{O}}+\mathrm{t} / \mathrm{k}+1 / \mathrm{h}_{\mathrm{i}}\right)=(1 / 15+0.0063 / 1.25+1 / 5)=0.272 \mathrm{~W} / \mathrm{m}^{2} \mathrm{~K} .
$$

Therefore,

$$
\begin{aligned}
& \mathrm{Q}_{\text {conv }, \mathrm{O}}+\mathrm{Q}_{\text {cond, } \mathrm{G}}+\mathrm{Q}_{\text {conv }, \mathrm{I}}=(\mathrm{Ts}-278) / 0.272 \mathrm{~W} / \mathrm{m}^{2} \mathrm{~K} \\
& \mathrm{Q}_{\text {cond }, \mathrm{S}}=\left(\mathrm{T}_{\mathrm{S}}-\mathrm{T}_{\mathrm{S} 1}\right) / \mathrm{U}_{2}
\end{aligned}
$$

where

$$
\mathrm{U}_{2}=\left(1 / \mathrm{h}_{\mathrm{i}}+3 / \mathrm{k}_{\mathrm{S}}\right)=(1 / 5+3 / 0.52)=5.97 \mathrm{~W} / \mathrm{m}^{2} \mathrm{~K} .
$$

Conductive heat loss through the soil is

$$
\mathrm{Q}_{\text {cond, } \mathrm{S}}=(\mathrm{Ts}-288) / 5.97 \mathrm{~W} / \mathrm{m}^{2} \mathrm{~K}
$$

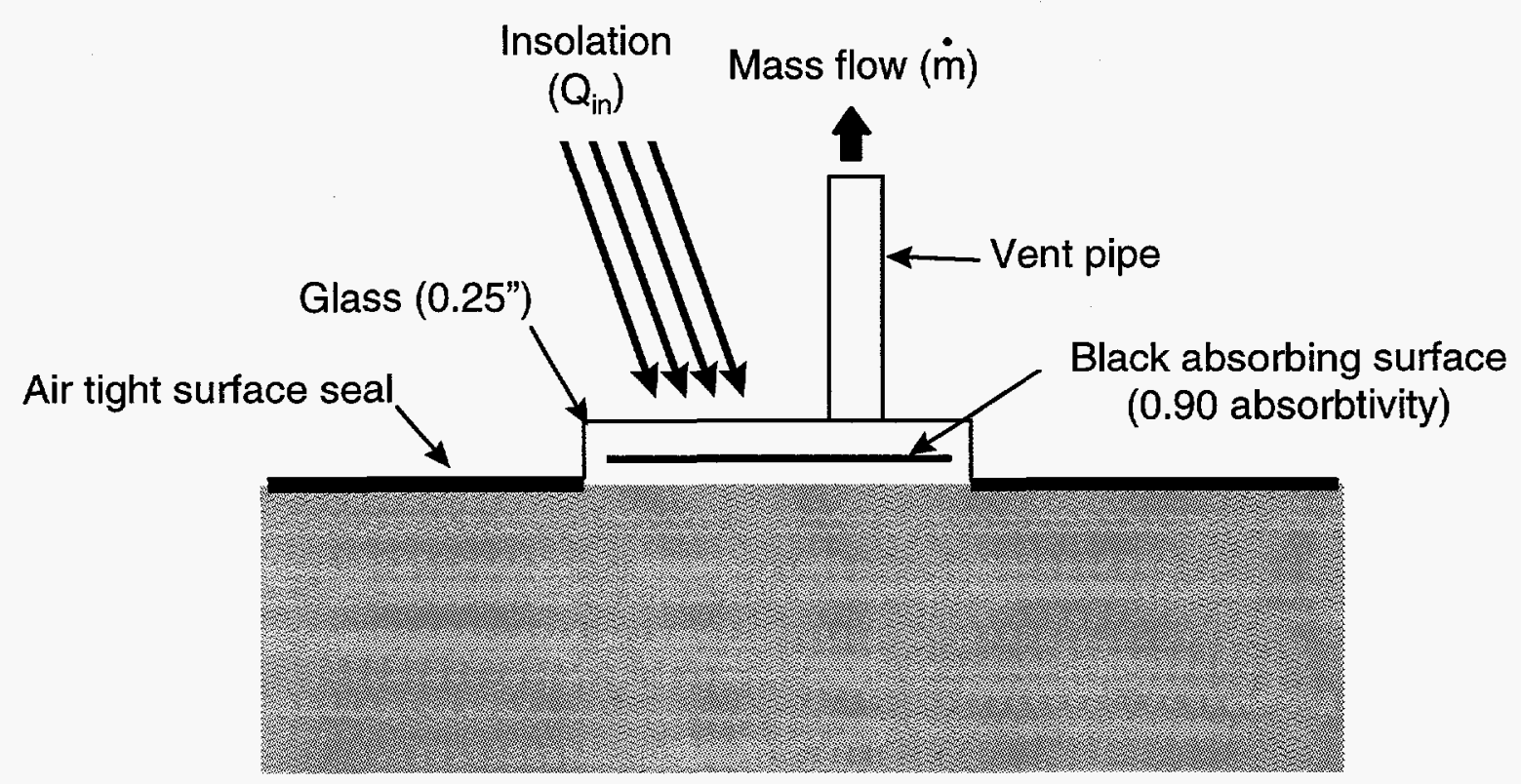

Figure 16. Conceptual model of plenum design which allows solar heating of the plenum gas to enhance the extraction rate of the remediation system. 
The total heat leaving the system is dependent on $\mathrm{T}_{\mathrm{s}}$ :

$$
\mathrm{Q}_{\text {out }}=(\mathrm{Ts}-278) / 0.272 \mathrm{~W} / \mathrm{m}^{2} \mathrm{~K}+(\mathrm{Ts}-288) / 5.97 \mathrm{~W} / \mathrm{m}^{2} \mathrm{~K}
$$

For steady conditions,

$$
\mathrm{Q}_{\text {out }}=\mathrm{Q}_{\text {in }}=71.07 \mathrm{~W} / \mathrm{m}^{2} \text {. }
$$

Solving for $\mathrm{T}_{\mathrm{s}}$ yelds an average absorber surface temperature inside the plenum:

$$
\mathrm{T}_{\mathrm{s}}=296.9 \mathrm{~K}
$$

The average air temperature is assumed to be the mean between the temperature of the absorbing surface and the inside temperature of the glass. The inside surface temperature can be calculated by determining the amount of energy transfer above the absorbing surface, $Q_{a b o v e}$.

$$
\begin{aligned}
& Q_{\text {above }}=Q_{\text {conv }, \mathrm{O}}+\mathrm{Q}_{\text {cond }, \mathrm{G}}+\mathrm{Q}_{\text {conv }, \mathrm{I}} \\
& \mathrm{Q}_{\text {above }}=(\mathrm{Ts}-278) / 0.272 \mathrm{~W} / \mathrm{m}^{2} \mathrm{~K}=(296.9-278) / 0.272 \mathrm{~W} / \mathrm{m}^{2} \mathrm{~K} \\
& \mathrm{Q}_{\text {above }}=69.552 \mathrm{~W} / \mathrm{m}^{2}
\end{aligned}
$$

The energy transfer through the air inside the plenum to the inside surface of the glass is then:

$$
\begin{aligned}
& \text { Qabove }=\left(\mathrm{T}_{\mathrm{S}}-\mathrm{T}_{\mathrm{g}}\right) \mathrm{h}_{\mathrm{i}}=\left(296.9-\mathrm{T}_{\mathrm{g}}\right) 5 \\
& \mathrm{~T}_{\mathrm{g}}=296.9-\left(69.552 \mathrm{~W} / \mathrm{m}^{2}\right) /\left(5 \mathrm{~W} / \mathrm{m}^{2} \mathrm{~K}\right)=282.9 \mathrm{~K}
\end{aligned}
$$

The average air temperature inside plenum is then

$$
\left(\mathrm{T}_{\mathrm{g}}+\mathrm{T}_{\mathrm{s}}\right) / 2=(282.9+296.9) / 2=\underline{289.9 \mathrm{~K}(62.5 \mathrm{~F})} \text {. }
$$

This results in an average temperature increase of $21.5 \mathrm{~F}$ over the ambient temperature outside of the plenum (41 F). Consequently, the difference in the density of the air inside and outside of the plenum is proportional to the ratio of the absolute temperatures, which is $(460+41) /(460+62.5)=0.96$. The air inside the plenum will be 0.96 as dense as the air outside of the plenum. If the plenum has a $10 \mathrm{ft}$ stack on its vent line, the resulting buoyant force is the product of the density difference times the height. Air at $41 \mathrm{~F}$ has a density of $0.068 \mathrm{lb} / \mathrm{ft}^{3}$. The air inside the plenum would be less dense by a factor of 0.96 , resulting in a density difference of $0.0027 \mathrm{lb} / \mathrm{ft}^{3}$.

Multiplying this times the height of the chimney ( $10 \mathrm{ft}$ ) results in a buoyant force of $0.027 \mathrm{lb} / \mathrm{ft}^{2}$, or $0.013 \mathrm{mbar}$. This is the equivalent additional vacuum the solar heating will impose on the plenum, which is not enough of an increase to warrant excessive modifications to the system. 


\section{SECTION 4.0}

\section{APPLICABILITY}

The proposed system is applicable to VOC contamination in the vadose zone. By design, it assures that the vapors emanating from a contaminant source in the soil will not be transported downward and will, instead, be brought to the surface and released into the air in small concentrations. The process is slow but steady, and does not require excavation, boreholes, or site power for operation. Several years will be required for complete remediation.

In general, this will be an attractive approach if one or several of the following conditions are met:

- The plume is not posing a significant, immediate threat to water contamination. The liquid source is not migrating downward at a rate which could not be counteracted by this system.

- The site has already been actively remediated (by vapor extraction, for example) but residual contamination exists. Incorporating this system can assure no residuals reach the water table, and it would remove residuals gradually over time.

- Usage of the site is not imminent. If, however, the site is a desirable location for a parking lot, the parking lot could perform the role of the surface seal.

The analyses presented in this document show that the surface treatment system will control and remediate volatile soil contaminants when the source is as deep as $4 \mathrm{~m}$ in the soil. It will induce significant upward soil gas velocities in soils with typical gas permeabilities, and depths to an impermeable layer even as shallow as 20 to $30 \mathrm{~m}$. These operating capabilities make it an attractive remediation technique for:

Recent surface spills of fuels, solvents, and other volatile chemicals

Buried pipe or drain line leaks

Leaking underground storage tanks

Shallow landfills containing hazardous volatile compounds. 


\section{SECTION 5.0}

\section{COST ASSESSMENT}

Cost of a typical barometric remediation installation will be low, primarily due to the lack of earth removal and/or boreholes. The major components of an installation are listed in the summary below, which estimates the cost for installation and abandonment of the barometric extraction system. Characterization and monitoring costs are not included here because they are common to any remediation system application.

\begin{tabular}{|c|c|c|c|}
\hline Cost Component & Unit Cost & $\begin{array}{c}\text { Small Site* } \\
(\$ 000)\end{array}$ & $\begin{array}{l}\text { Large Site** } \\
\quad(\$ 000)\end{array}$ \\
\hline \multicolumn{4}{|l|}{ Materials: } \\
\hline Sealant: 20 mil poly sheeting & $\$ 0.15 / \mathrm{ft}^{2}$ & $\$ 0.06$ & $\$ 0.5$ \\
\hline Plenum fill gravel & $\$ 45 / y d^{3}$ & .3 & 8.3 \\
\hline $\begin{array}{l}\text { Vent pipe, flapper valve, turbine } \\
\text { ventilator, supports, vapor points }\end{array}$ & $\$ 1 K /$ assy & 1.0 & 1.0 \\
\hline \multicolumn{4}{|l|}{ Labor: } \\
\hline Mobilization/demobilization & $\$ 1 \mathrm{~K}$ & 1.0 & 1.0 \\
\hline Surface grading and leveling & $\$ 45 / \mathrm{hr}$ & $.36(8 \mathrm{hr})$ & $.72(16 \mathrm{hr})$ \\
\hline Installation (cover, plenum, vent) & $\$ 50 / \mathrm{hr}$ & $1.6(32 \mathrm{hr})$ & $3.2(64 \mathrm{hr})$ \\
\hline Abandonment (removal/reclamation) & $\$ 50 / \mathrm{hr}$ & $1.6(32 \mathrm{hr})$ & $3.2(64 \mathrm{hr})$ \\
\hline SUBTOTAL & & 5.9 & 18.9 \\
\hline Escalation (10\%) & & .59 & 1.9 \\
\hline SUBTOTAL & & 6.5 & 20.8 \\
\hline Contingency and Proj. Mgmt. (@35\%) & & 2.3 & 7.28 \\
\hline TOTAL & & $\$ 8.8 \mathrm{~K}$ & $\$ 28.1 \mathrm{~K}$ \\
\hline
\end{tabular}

*Small Site: $10 \mathrm{ft}$ diameter plenum, $20 \mathrm{ft}$ square buffer zone

**Large Site: $50 \mathrm{ft}$ diameter plenum, $100 \mathrm{ft}$ square buffer zone

\section{Costs of conventional techniques}

To compare with conventional techniques, the following cost estimates were produced using the Remedial Action Cost Engineering and Requirements (RACER) system developed by the U.S. Air Force. RACER consists of two components which include the Remedial Action Assessment System (RAAS) and the cost estimating model (ENVEST $^{\mathrm{TM}}$ ). ENVEST $^{\mathrm{TM}}$ is a management tool specifically designed for estimating the costs of remedial investigations, remedial designs, and remedial actions. RACER includes a number of remediation technology models. Several of these technology models have been selected to illustrate costs associated with comparable 
methods of site remediation. These models include soil vapor extraction, in situ biodegradation, low temperature thermal desorption, landfill disposal, and UST closure.

Each remediation technology model is designed to accept input from the user to define the contaminated site. For the purposes of this study, a number of assumptions were used to define a sample site. The sample site is based on a contaminated site with dimensions of $16 \mathrm{ft}$ wide, $61 \mathrm{ft}$ long, $16 \mathrm{ft}$ deep for a total of 151 cubic yards. The contaminate is assumed to be a volatile organic compound (VOC) located in the vadose zone. The soil consists primarily of sand sized particles. Work is accomplished using safety level D. The start-up period is assumed to be 4 weeks with operation and maintenance for 24 weeks. Distance to the vendor from the site is assumed to be 200 miles. No characterization or monitoring costs are considered in these estimates.

A summary table presents the cost estimate for each remediation technology model based on the assumptions previously discussed. Each cost estimate includes a breakdown of costs by capital, operation and maintenance (O\&M), and total. Contingencies are estimated to be 25 percent of the total cost. Project Management is estimated to be 10 percent of total cost.

\section{Soil Vapor Extraction}

Soil vapor extraction is designed to remove VOCs from the vadose zone. A soil vapor extraction system typically consists of a number of vapor extraction wells and an air handling system to draw air through the contaminated soil. This model is based on a single vapor extraction point installed to a depth of $50 \mathrm{ft}$ using a hollow stem auger. As the air is drawn through the contaminated soil, VOCs are vented to the atmosphere.

\begin{tabular}{|l|c|c|c|}
\hline \multicolumn{1}{|c|}{$\begin{array}{c}\text { Remedial action: } \\
\text { Soil vapor extraction }\end{array}$} & $\begin{array}{c}\text { Capital costs } \\
\mathbf{( \$ 0 0 0 )}\end{array}$ & $\begin{array}{c}\text { O\&M costs } \\
\mathbf{( \$ 0 0 0 )}\end{array}$ & $\begin{array}{c}\text { Total cost } \\
\mathbf{( \$ 0 0 0 )}\end{array}$ \\
\hline \hline Soil Vapor Extraction & $\$ 26$ & 9 & 35 \\
Indirect, Overhead, and Profit $(25.2 \%)$ & & & 9 \\
SUBTOTAL & & & $\$ 44$ \\
Escalation (9.8\%) (1995/12) & & & $\$ 48$ \\
SUBTOTAL & & & 17 \\
Contingencies and Proj. Management (35\%) & & & $\$ 65$ \\
TOTAL & & & 4 \\
\hline
\end{tabular}

\section{In Situ Biodegradation}

Biodegradation is a natural process involving the microbial transformation of organic constituents found in soil and ground water. The rate of natural biodegradation can vary between sites depending on the conditions. A number of factors influence conditions necessary for biodegradation to be an effective remediation method. These factors include soil moisture, oxygen content, $\mathrm{pH}$, temperature, and nutrients. Each of these factors can be altered, as 
needed, to increase the rate of biodegradation of organic constituents. For example, this model relies on a vapor extraction point using one well connected to a blower to facilitate oxygen flow through the contaminated soil. This model also includes a sprinkler system to ensure adequate supply of moisture to the microorganisms. Finally, the model assumes the addition of nutrients to the site in the form of pulverized fertilizer.

\begin{tabular}{|l|c|c|c|}
\hline \multicolumn{1}{|c|}{$\begin{array}{c}\text { Remedial action: } \\
\text { In-situ biodegradation }\end{array}$} & $\begin{array}{c}\text { Capital costs } \\
\mathbf{( \$ 0 0 0 )}\end{array}$ & $\begin{array}{c}\mathbf{0 \& M} \text { costs } \\
\mathbf{( \$ 0 0 0 )}\end{array}$ & $\begin{array}{c}\text { Total cost } \\
\mathbf{( \$ 0 0 0 )}\end{array}$ \\
\hline \hline In Situ Biodegradation & $\$ 35$ & 9 & 44 \\
Indirect, Overhead, and Profit $(26.1 \%)$ & & & 12 \\
SUBTOTAL & & & $\$ 56$ \\
Escalation (9.8\%) (1995/12) & & & 5 \\
SUBTOTAL & & & $\$ 61$ \\
Contingencies and Proj. Management (35\%) & & & 21 \\
TOTAL & & & $\$ 82$ \\
\hline
\end{tabular}

\section{Low Temperature Thermal Desorption}

Thermal desorption is a method of remediation designed to remove the organic contaminants from the soil. Low temperature thermal desorption refers to the use of relatively low temperatures in the 300 to $600^{\circ} \mathrm{Fahrenheit}$ range. Prior to treatment, the contaminated soil is excavated from the site. Excavation includes the costs associated with handling and transporting contaminated soils from the site to the treatment facility.

\begin{tabular}{|l|c|c|c|}
\hline \multicolumn{1}{|c|}{ Remedial action: } & $\begin{array}{c}\text { Capital costs } \\
\mathbf{( \$ 0 0 0 )}\end{array}$ & $\begin{array}{c}\text { O\&M costs } \\
\mathbf{( \$ 0 0 0 )}\end{array}$ & $\begin{array}{c}\text { Total cost } \\
\mathbf{( \$ 0 0 0 )}\end{array}$ \\
\hline Excavation, Buried Waste & $\$ 78$ & 9 & $\$ 78$ \\
Low Temperature Thermal Desorption & $\$ 467$ & & 467 \\
Indirect, Overhead, and Profit (19.7\%) & & & 108 \\
SUBTOTAL & & & $\$ 653$ \\
Escalation (9.8\%) (1995/12) & & & 64 \\
SUBTOTAL & & & $\$ 717$ \\
Contingencies and Proj. Management (35\%) & & & 251 \\
TOTAL & & & $\$ 968$ \\
\hline
\end{tabular}

\section{Landfill Disposal}

Contaminated soil must be disposed of in a permitted landfill facility designed and operated in accordance with current Federal and state standards. Primary costs associated with landfill disposal are trucking and disposal fees. Disposal fees can vary widely, depending on the type of facility and the regional location. For this model a 
disposal fee of $\$ 99.99$ was used, based on an average of regional fees from landfill facilities accepting contaminated soils considered to be hazardous waste. Prior to disposal, the contaminated soil is excavated from the site.

Excavation includes the costs associated with handling and transporting contaminated soils from the site to the disposal facility.

\begin{tabular}{|l|c|c|c|}
\hline \multicolumn{1}{|c|}{$\begin{array}{c}\text { Remedial action } \\
\text { Landfill disposal }\end{array}$} & $\begin{array}{c}\text { Capital costs } \\
\mathbf{( \$ 0 0 0 )}\end{array}$ & $\begin{array}{c}\text { O\&M costs } \\
\mathbf{( \$ 0 0 0 )}\end{array}$ & $\begin{array}{c}\text { Total cost } \\
\mathbf{( \$ 0 0 0 )}\end{array}$ \\
\hline \hline Excavation, Buried Waste & $\$ 78$ & & $\$ 78$ \\
Landfill Disposal & $\$ 22$ & & 22 \\
Indirect, Overhead, and Profit (27.6\%) & & & 28 \\
SUBTOTAL & & & $\$ 128$ \\
Escalation (9.8\%) (1995/12) & & & 13 \\
SUBTOTAL & & & $\$ 141$ \\
Contingencies and Proj. Management (35\%) & & & $\$ 190$ \\
TOTAL & & & \\
\hline
\end{tabular}

Summary

This cost assessment indicates the relative scale of remediation costs using conventional techniques compared with the barometric pumping system. In general, any conventional techniques will cost in excess of $\$ 50 \mathrm{~K}$ to remediate a contaminated site. The barometric pumping system, because it requires no earth removal or boreholes, will cost less than $\$ 30 \mathrm{~K}$. Costs are summarized as:

Barometric pumping without boreholes

Soil vapor extraction

Low temperature thermal desorption

Landfill disposal
\$28.1K

$\$ 65.0 \mathrm{~K}$

\$968K

$\$ 190 \mathrm{~K}$ 


\section{SECTION 6.0}

\section{SUMMARY}

Natural oscillations in barometric pressure induce periodic vertical displacements in soil gas. These displacements can range in amplitude from centimeters to meters, depending on soil gas permeability and depth to the water table. The source of the most rapid soil gas displacement is the daily (diurnal) 5 mbar average variation in barometric pressure. The motions are sinusoidal and do not result in net vertical soil gas displacement over time (except very near the surface of the soil, where the gas releases to the atmosphere on the upward cycle). However, if this process is controlled it offers a continuous, natural, and inexpensive method to remediate VOC plumes in the vadose zone.

This report evaluates the effectiveness of a surface treatment design which capitalizes on the naturally occurring barometric pressure oscillations to remediate near surface volatile contamination in the vadose zone. By applying a surface seal, collection plenum, and one way relief valve to the soil surface above the contaminant plume, this system induces a net upward soil gas velocity in the contaminated soil. The sinusoidal velocity is rectified to eliminate or minimize its downward velocity component and allow the normal upward component. The resulting net upward velocity sweeps contaminant vapors up from the source, releasing them to the atmosphere in small concentrations. This process is regular and steady, and is accomplished without the use of boreholes, off-gas treatment, or site power.

For this system to be practical and cost-effective, it must ensure that most or all of the contaminants evaporating and diffusing from a liquid source in the soil are swept upward. The opposing mechanisms that must be overcome are the diffusion of vapors downward from the source and density driven downward flow caused by thermal and contaminant concentration gradients in the soil gas. To assess the performance, the following tasks were accomplished in this Phase I effort:

- Meteorologic data for seven sites near major DOE installations were reviewed. This established the magnitude, variability, and frequency of barometric pressure oscillations across the nation. Air temperature and wind speed data were also compiled.

- Transport and hazard characteristics of the major volatile contaminants found throughout the DOE complex were summarized to provide data needed for transport calculations.

- The naturally occurring soil gas displacement, due to an oscillatory surface pressure, was predicted for a range of geometric and flow conditions. This analysis defined the highest attainable soil gas velocities under ideal conditions.

- The opposing contaminant transport processes were analyzed to determine the net upward velocities required to overcome the opposing (downward) contaminant transport. These processes include diffusion and density-induced gravitational flow due to concentration and thermal gradients. 
- A transient two-dimensional analysis was conducted of a typical surface treatment installation to predict the system's performance. Using the Los Alamos FEHM code, the advective gas flow resulting from the oscillatory surface pressure was predicted throughout the soil volume of interest. Results from this analysis were compared to estimates of contaminant transport rates due to diffusion and density gradients.

- Costs of a typical system installation were compared to remediation costs using conventional techniques.

- Enhancements to the system operation, capitalizing on wind and solar heating, were studied to determine their potential boost to the system's performance.

The data review, analytical modeling, and numerical simulation confirmed that the surface treatment system imposes net upward soil gas velocities at depths typical of shallow soil contamination. Furthermore, the induced velocities were of magnitudes capable of overcoming the downward transport rates due to diffusion and density gradients. The following summaries clarify and support these conclusions.

\section{Naturally occurring air flow rates in soils}

Soil gas moves naturally in soil, and is sinusoidal in nature. Its dominant frequency and magnitude are due to the daily 5 mbar variation which results from heating and cooling of the atmosphere. In higher permeability soil, the velocities will be greater for a given atmospheric pressure variation. Peak velocity also increases as the depth to an impermeable layer increases. The peak soil gas velocity, determined by analytically modeling the soil gas response, will range from 0.2 to $0.8 \mathrm{~m} /$ day for a typical range in permeability ( 1 to 10 Darcies) and depths to an impermeable layer of $50 \mathrm{~m}$ or more. Under natural conditions, this oscillatory movement results in no net flow because it always returns to its mean value.

\section{Net soil gas movement due to the surface treatment}

The surface treatment (seal, collection plenum, and vent valve) effectively rectifies the sinusoidal soil gas velocity by minimizing the downward component. This results in a net upward component over time, which is at a maximum just beneath the plenum. The maximum attainable (average) soil gas flux at the surface ranges from 0.03 to $0.07 \mathrm{~m}^{3} / \mathrm{m}^{2}$-day. To determine the effects of field conditions, a typical surface treatment was analyzed with a transient multidimensional numerical code to predict the system's performance.

The numerical simulation demonstrated that at the soil surface, the system results in a net upward flow equal to the maximum attainable rectified flux. The flow rates predicted numerically were compared with processes which would transport contaminants downward toward the water table. These processes are: concentration-induced density gradients, diffusion, and temperature-induced density gradients. Each of these mechanisms results in a maximum transport rate at the source, then a diminishing transport rate as depth increases. The key results of the comparison are: 
Concentration induced density gradients - The density gradients resulting from the contaminant concentration distribution (due to diffusion from the source) impose a downward flow from the source. The advective velocity resulting from the surface treatment system is capable of exceeding the downward transport rate with a source as deep as $4 \mathrm{~m}$.

Diffusion - The surface treatment system induces soil gas velocities which overpower the downward diffusion rates. For a planar contaminant source, the net advective upward velocity exceeded downward diffusion of TCE for a source as deep as $10 \mathrm{~m}$.

Thermally induced density gradients - Seasonal heating and cooling of the soil surface will cause temperature gradients in the soil which will induce density gradients in the soil gas. This is shown to be the easiest of the three transport processes to overcome: the surface treatment causes a net upward velocity almost ten times that required to overcome the temperature induced buoyant flow.

\section{Contaminant removal rate}

The maximum attainable contaminant removal rate is defined by how readily the contaminants evaporate and diffuse away from the source. This is true if the surface treatment system sweeps all the contaminated vapors upward from a source, which the analysis predicts to be the case. The maximum TCE transport rate from a planar source is $0.1 \mathrm{mg} / \mathrm{s}-\mathrm{m}^{2}$. If the source is $5 \mathrm{~m}$ in diameter and the TCE diffuses from both the top and bottom of the source, this translates to a daily removal rate of $0.34 \mathrm{~kg}$, or $124 \mathrm{~kg} /$ year. Total remediation time will depend on the mass of contaminants present, but will likely range from one to several years.

\section{$\underline{\text { Cost effectiveness }}$}

An estimate of the cost to install this system was compared to estimates of conventional remediation technologies. A baseline barometric pumping installation, covering a contaminant source roughly $10 \mathrm{~m}$ in diameter, is estimated to cost $\$ 28 \mathrm{~K}$. This is less than half the cost estimated for conventional solutions.

\section{Applicability}

The system is applicable to volatile contamination from sources such as leaking underground storage tanks, buried pipelines, surface spills, and landfills in the vadose zone. Its depth of influence is adequate to treat many of these circumstances. The system is very inexpensive, requires virtually no maintenance, and can treat many of the sites in which no immediate threat to the water table exists. Installations can be unobtrusive: parking lots and concrete pads can actually be part of the surface seal while allowing the land to be used for other purposes. 


\section{SECTION 7.0 \\ ACKNOWLEDGEMENTS}

The authors gratefully acknowledge the funding support of DOE EM-50, the DOE Morgantown Energy Technology Center, Mr. Carl Roosmagi (the original METC contract technical representative) and Dr. Kelly Pearce, the present technical representative. The efforts of SEA staff are also noted: Janice Johnston for preparing this document, and Tom Colina for the laboratory tests.

We also thank the Los Alamos National Laboratory EES-5 division for help with the FEHM calculations. In particular, Lynn Trease and Nina Rosenburg provided assistance in operating the code. 


\section{SECTION 8.0}

\section{REFERENCES}

1 C. Williams, W. Lowry, D. Cremer, and S. Dalvit Dunn, "SEAMIST"TM In-Situ Instrumentation and Vapor Sampling System Applications in the Sandia Mixed Waste Landfill Integrated Demonstration Program: Final Report," Sandia National Laboratories, SAND95-2060, September 1995.

2 G. A. Zyvoloski and Z. V. Dash, "Software Verification Report FEHMN Version 1.0," LA-UR-91-609, 1991.

3 G. A. Zyvoloski, B. A. Robinson, Z. V. Dash, and L. L. Trease, "Models and Methods Summary for the FEHMN Application," LA-UR-94-3787, Rev. 1, May 1995.

4 G. A. Zyvoloski, B. A. Robinson, Z. V. Dash, and L. L. Trease, "Users Manual for the FEHMN Application," LA-UR-94-3788, Rev. 1, July 1995. 


\section{APPENDIX A. METEOROLOGICAL DATA}

Changes in weather conditions drive the performance of the passive barometric remediation system. To define typical ranges of these conditions and to determine if there are any significant differences in conditions for different geographic local, data from the NCDC (National Climactic Data Center, U. S. Weather Service) was analyzed. Seven sites across the United States were chosen for analysis. The sites were chose to represent topographic and climactic extremes, and to be representative of conditions at DOE facilities. The sites (Figure A1) were: Albuquerque, NM; Augusta, GA; Boulder, CO; Knoxville, TN; Pendelton, OR; Pocatello, ID; and San Francisco, CA. Figures A2 through A8 show temperature, pressure differential from the average, and windspeed data for each of the sites for the one year period between March 1, 1989 and February 28, 1990. Table A1 lists the average, maximum, and minimum values for each data set, as well as the standard and average deviations. Data was collected and is plotted on an hourly basis. Figure A9 shows the same data over a one month period for Albuquerque, NM. The expanded time scale clearly shows daily pressure and temperature oscillations. To assure the one year period chosen was not statistically significantly different from other years, the analyses were also performed over the one year period between March 1, 1979 and February 29, 1980. Statistical results did not change significantly.

Average temperatures for the sites varied between $8.9 \mathrm{C}$ in Pocatello, ID and 17.6 C in Augusta, GA. The average difference between the maximum and minimum temperatures at the sites was $50 \mathrm{C}$; the average standard deviation at the sites was $9.1 \mathrm{C}$. In addition to daily cycles and the shorter temperature fluctuations associated with weather fronts, each of the sites showed an underlying sinusoidal yearly cycle associated with seasonal changes. Figure A10 depicts this more dramatically by plotting a 21 year period starting January 1, 1970, for Albuquerque, NM. The amplitude of the yearly cycle for all sites was approximately $25 \mathrm{C}$.

Pressure histories for the different sites also show some similarities. The summer season (June through August) shows the smallest pressure fluctuations; the winter season (December through February) shows the greatest fluctuations. The standard deviation for each of the sites was around 5 mbars. Pressure data was plotted as the difference between the measured pressure and the average yearly pressure for ease of comparison between the sites. The average pressure of the sites varied from 1017 mbars in San Francisco, CA to 836 mbars in Boulder, CO. Fourier transforms were performed on the data, for both yearly and seasonal periods. Typical results are shown in Figures A11 and A12. While the analysis clearly showed the daily pressure oscillation period, longer term oscillations due to passing weather fronts were not as well defined, especially over the yearly period. Weak cycles around 200 and 300 hours were seen in most of the analysis, and were used in calculations performed throughout this report. The average amplitudes of the pressure oscillations for the three defined periods are shown in Table A2. This data supports the general statement that daily atmospheric pressure changes are typically of 5 mbar magnitude. Variations on longer periods ( 8 and 13 days) were of 12 to almost 22 mbar magnitudes. 


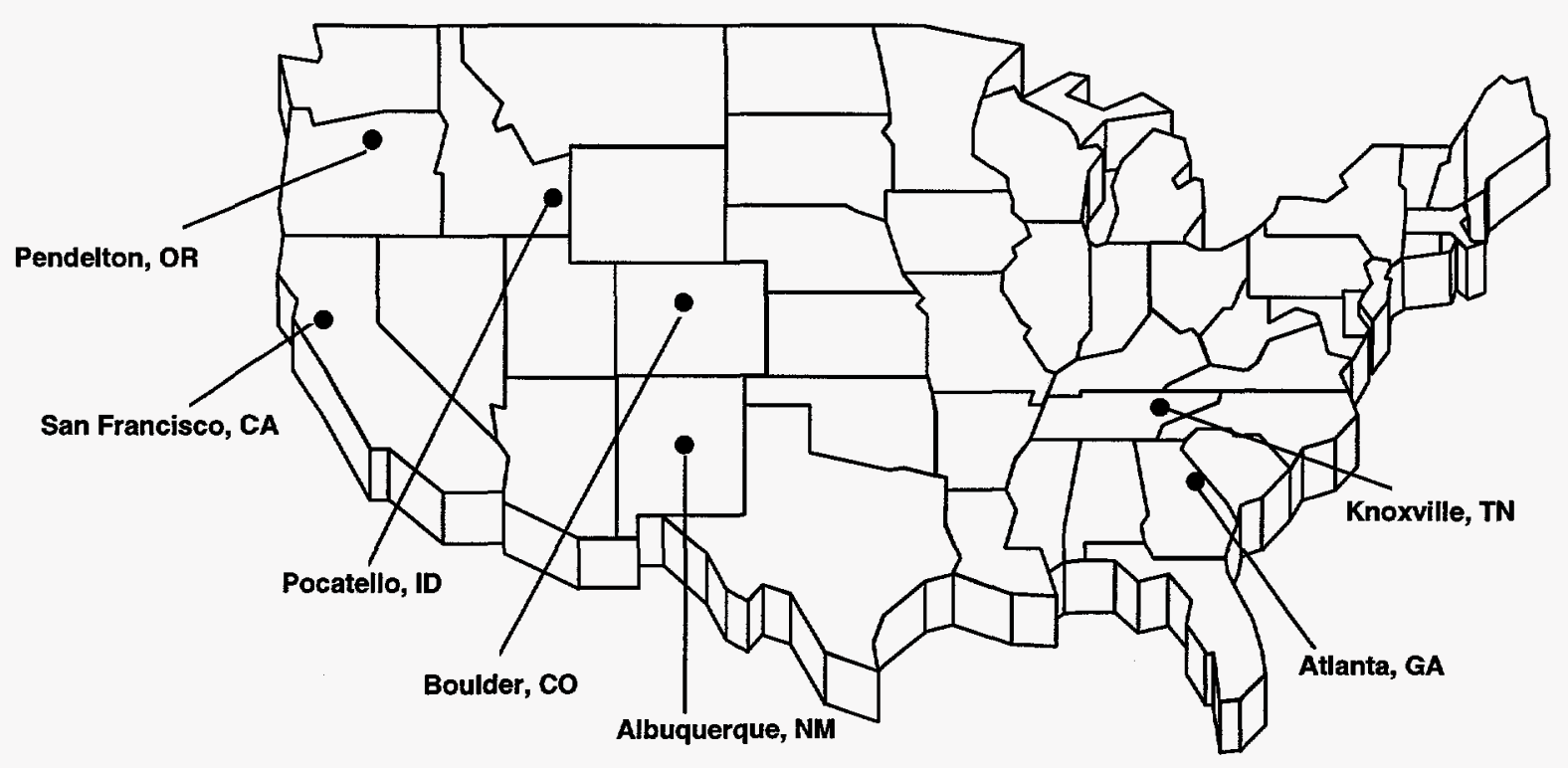

Figure A1. Location of sites chosen for analysis. 

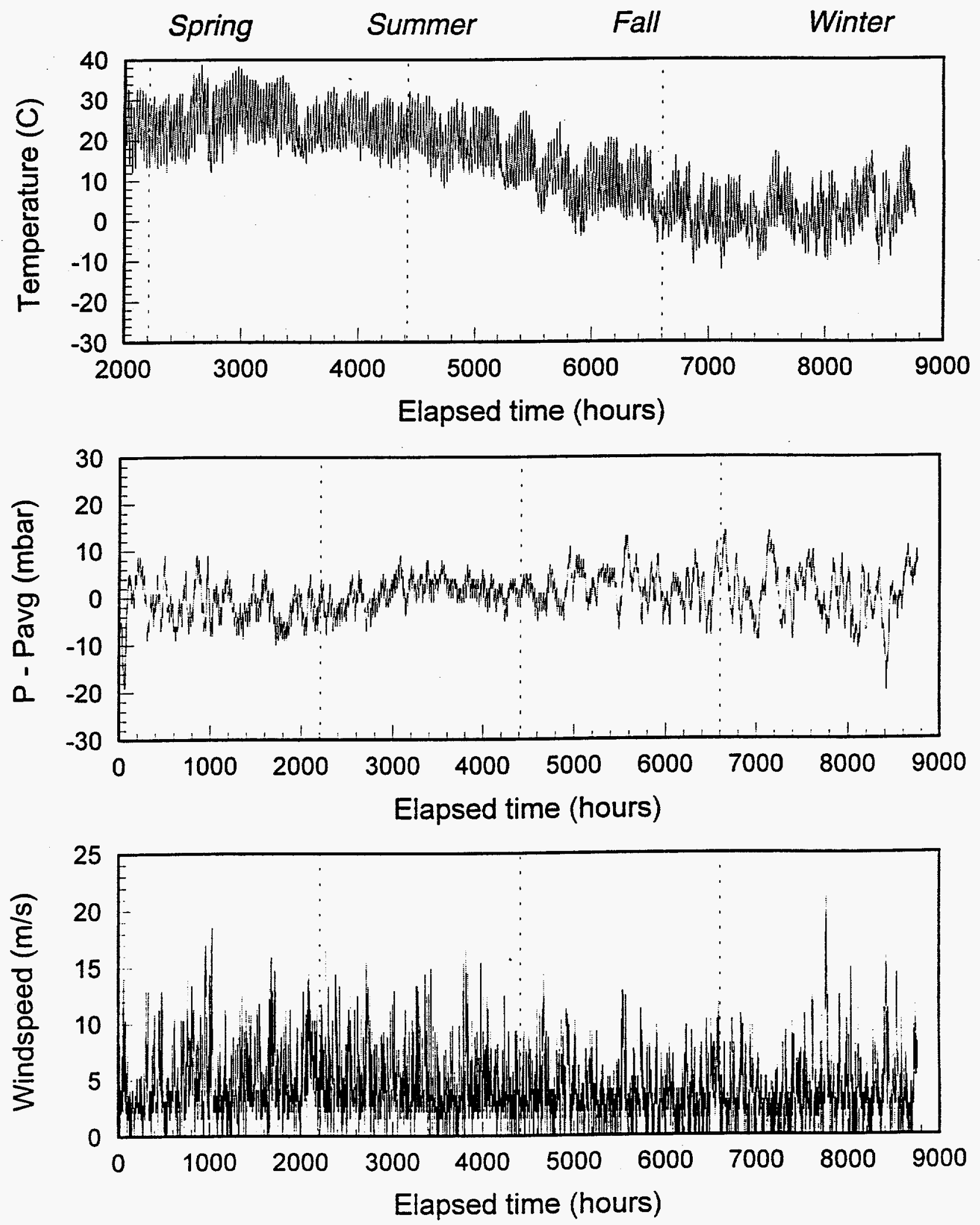

Figure A2. Climatic data for the one year period between March 1, 1989 and February 28, 1990 for Albuquerque, NM: 

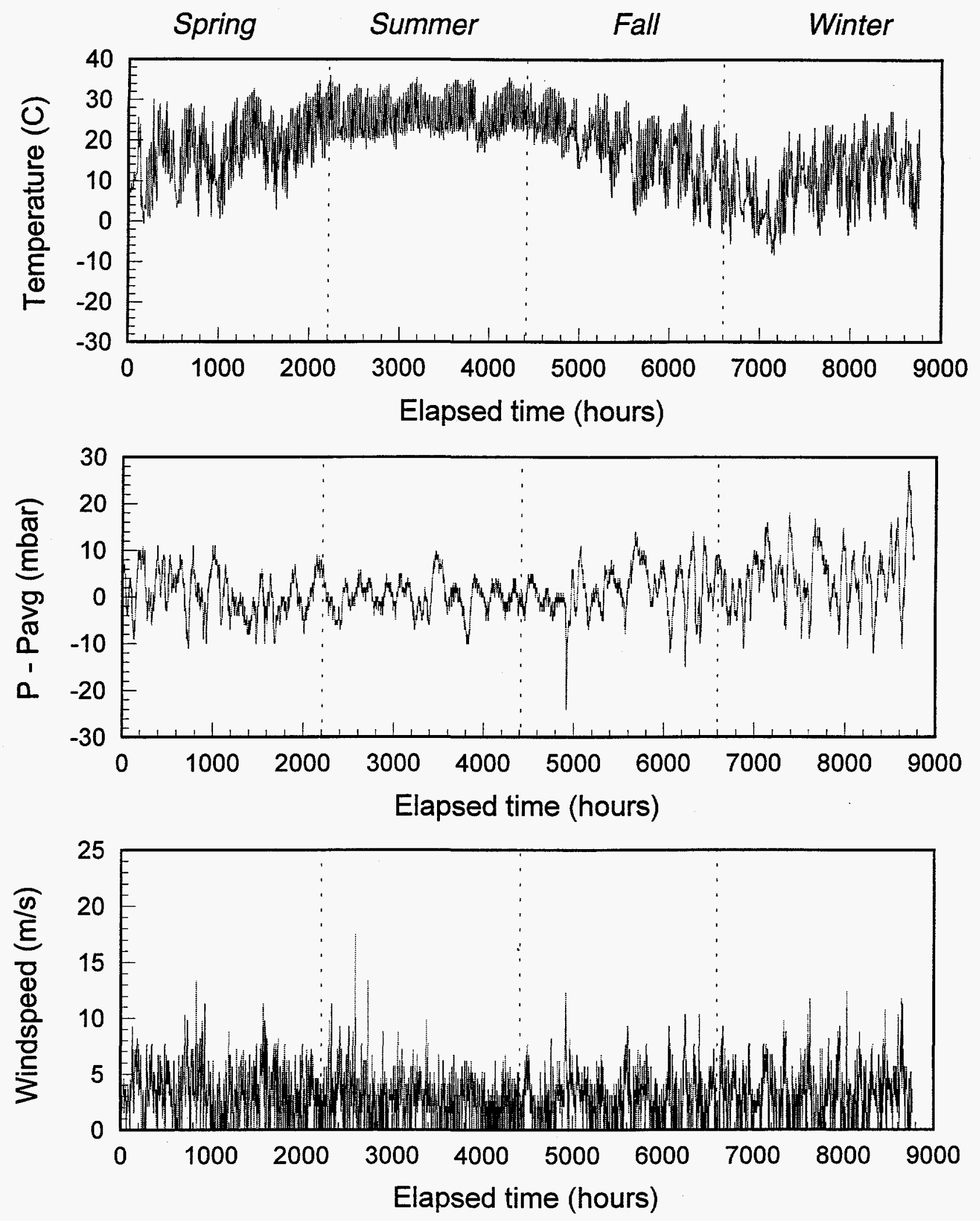

Figure A3. Climatic data for the one year period between March 1, 1989 and February 28, 1990 for Augusta, GA. 

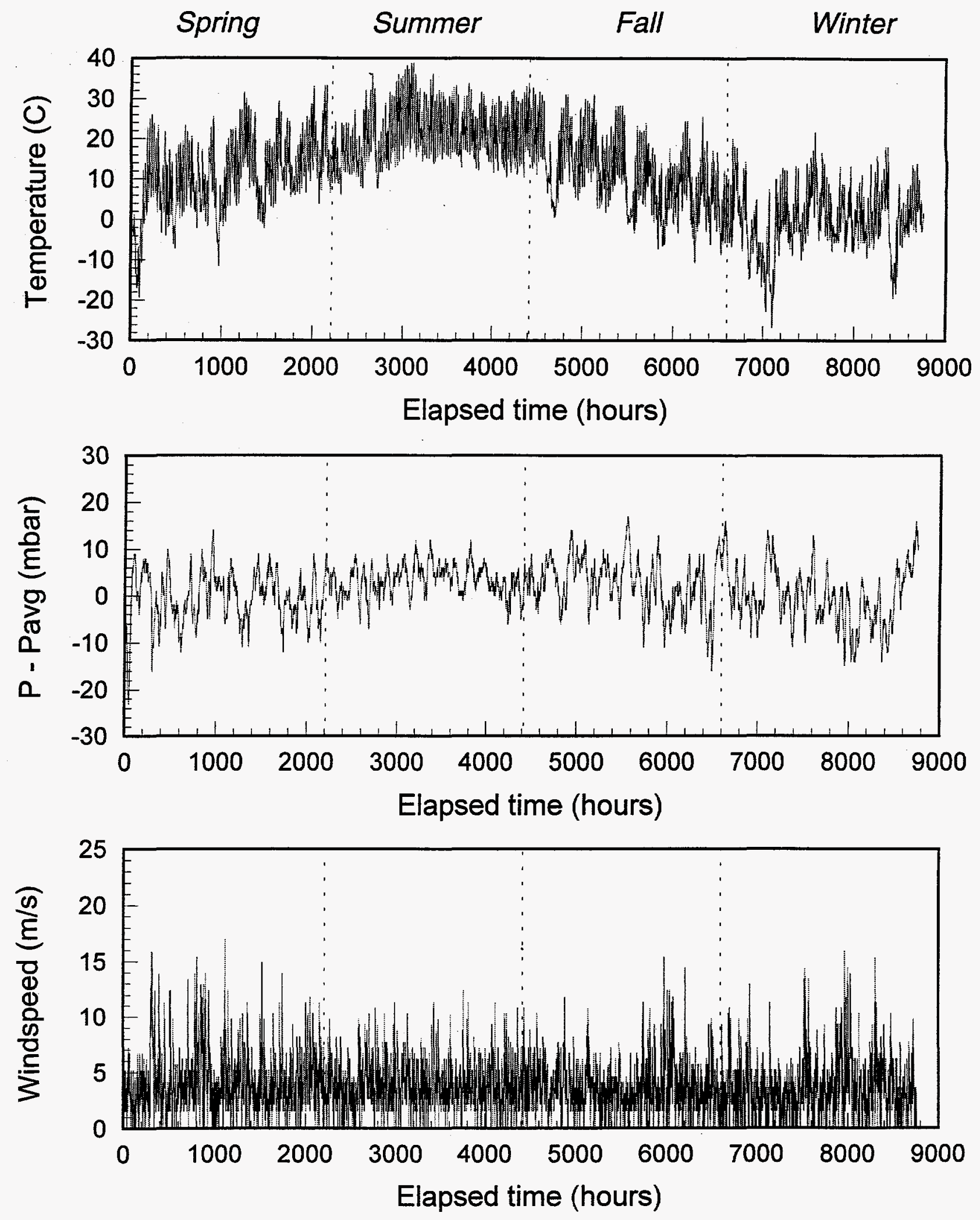

Figure A4. Climatic data for the one year period between March 1, 1989 and February 28, 1990 for Boulder, CO. 

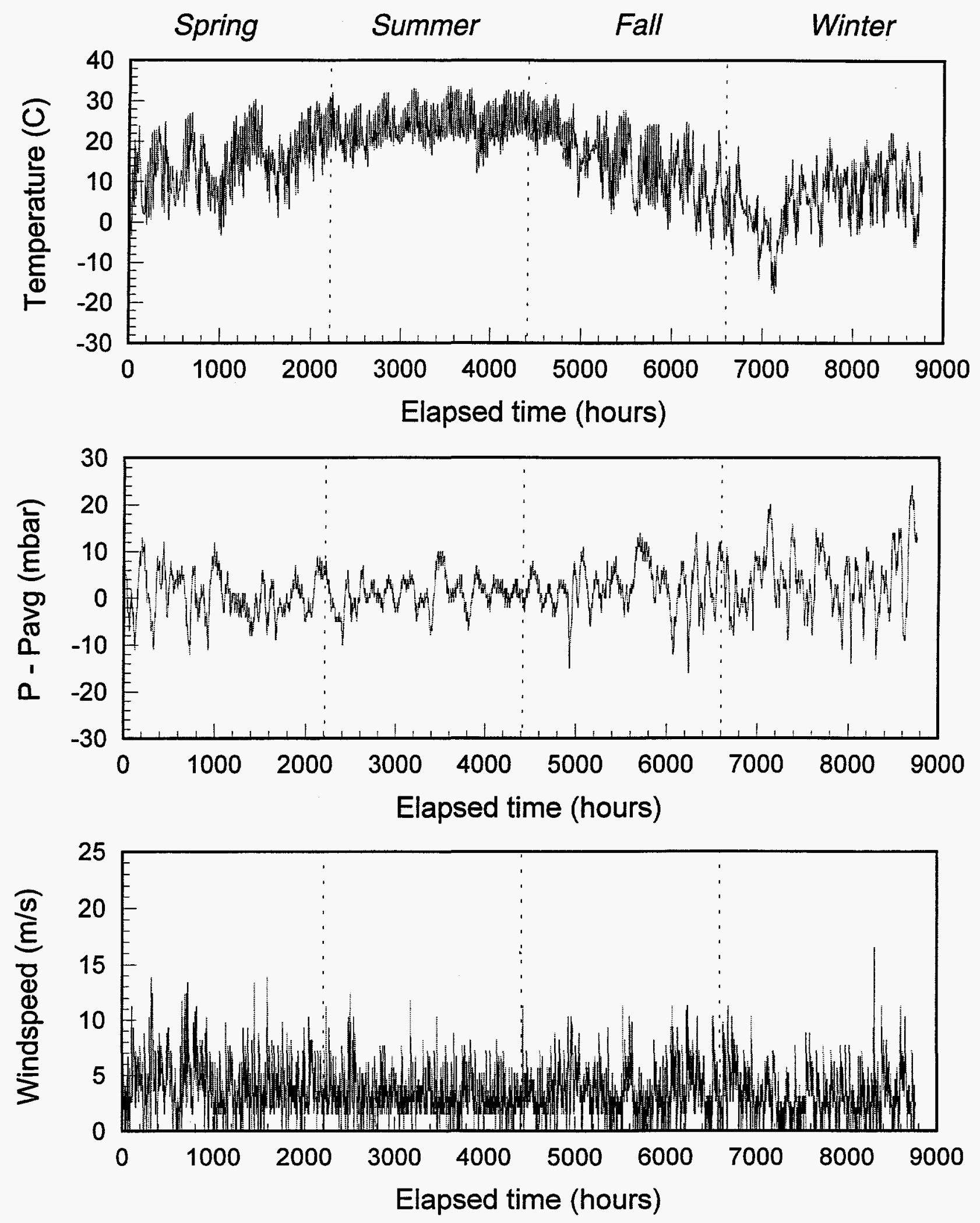

Figure A5. Climatic data for the one year period between March 1, 1989 and February 28, 1990 for Knoxville, TN. 

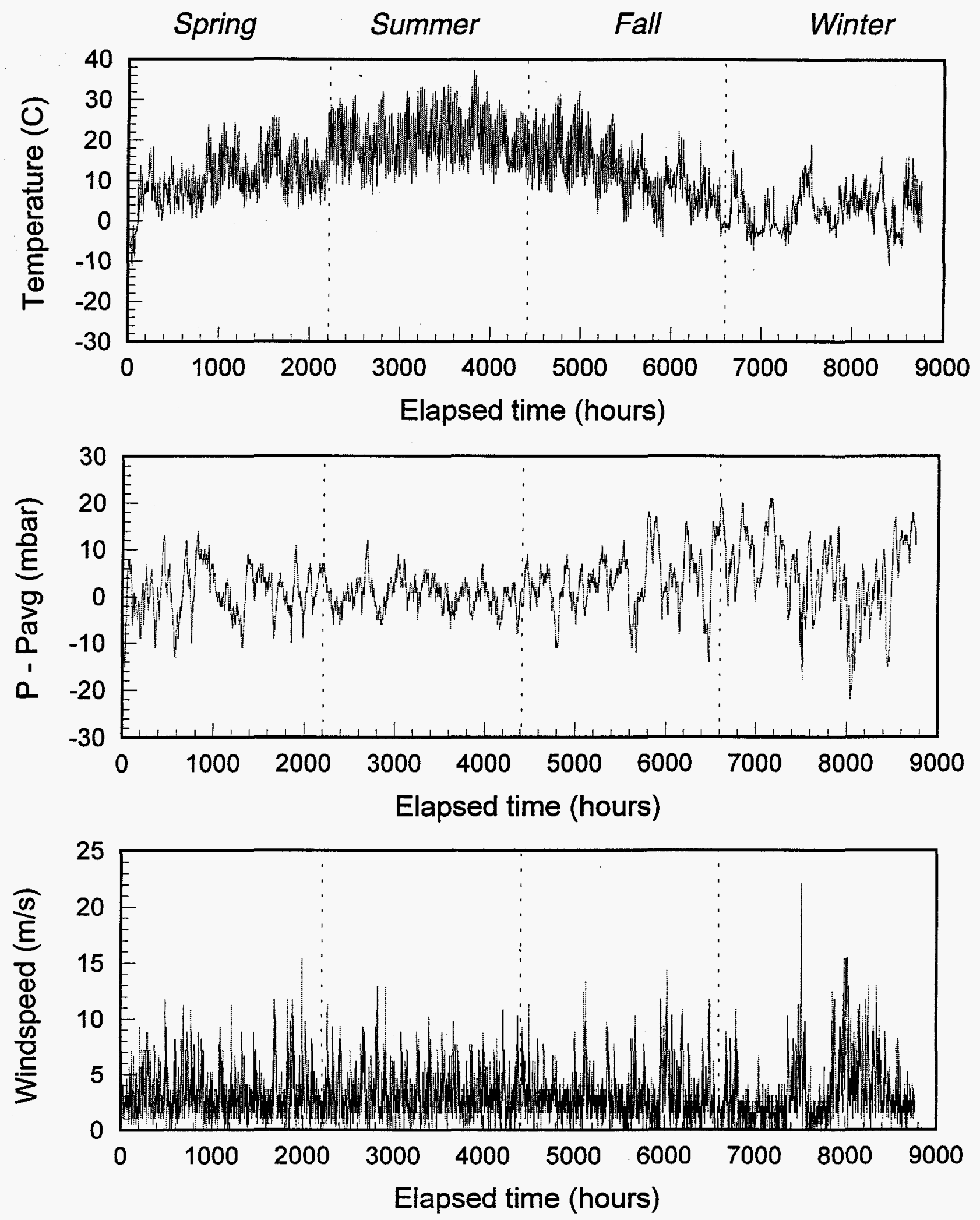

Figure A6. Climatic data for the one year period between March 1, 1989 and February 28, 1990 for Pendelton, OR. 

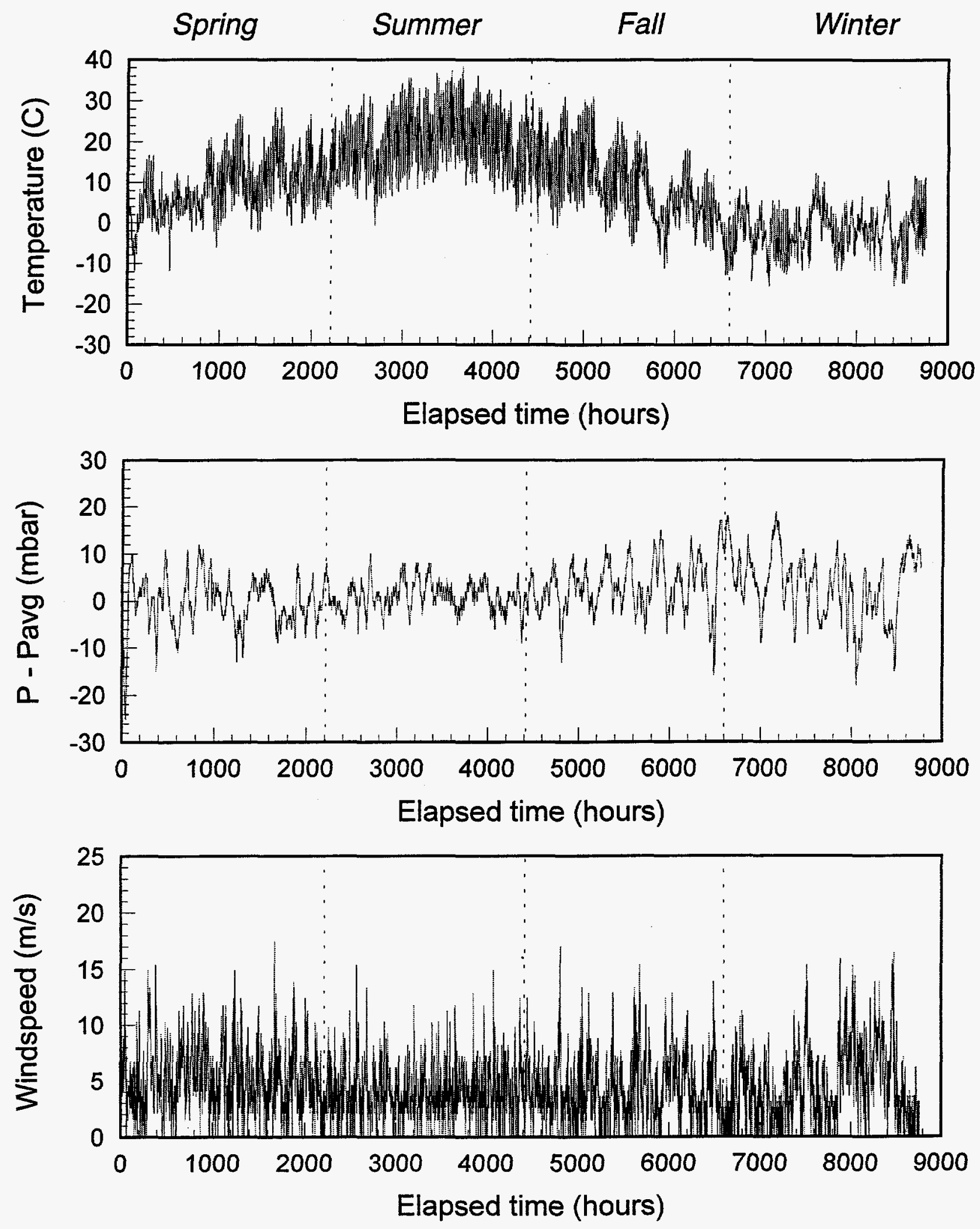

Figure A7. Climatic data for the one year period between March 1, 1989 and February 28, 1990 for Pocatello, ID. 

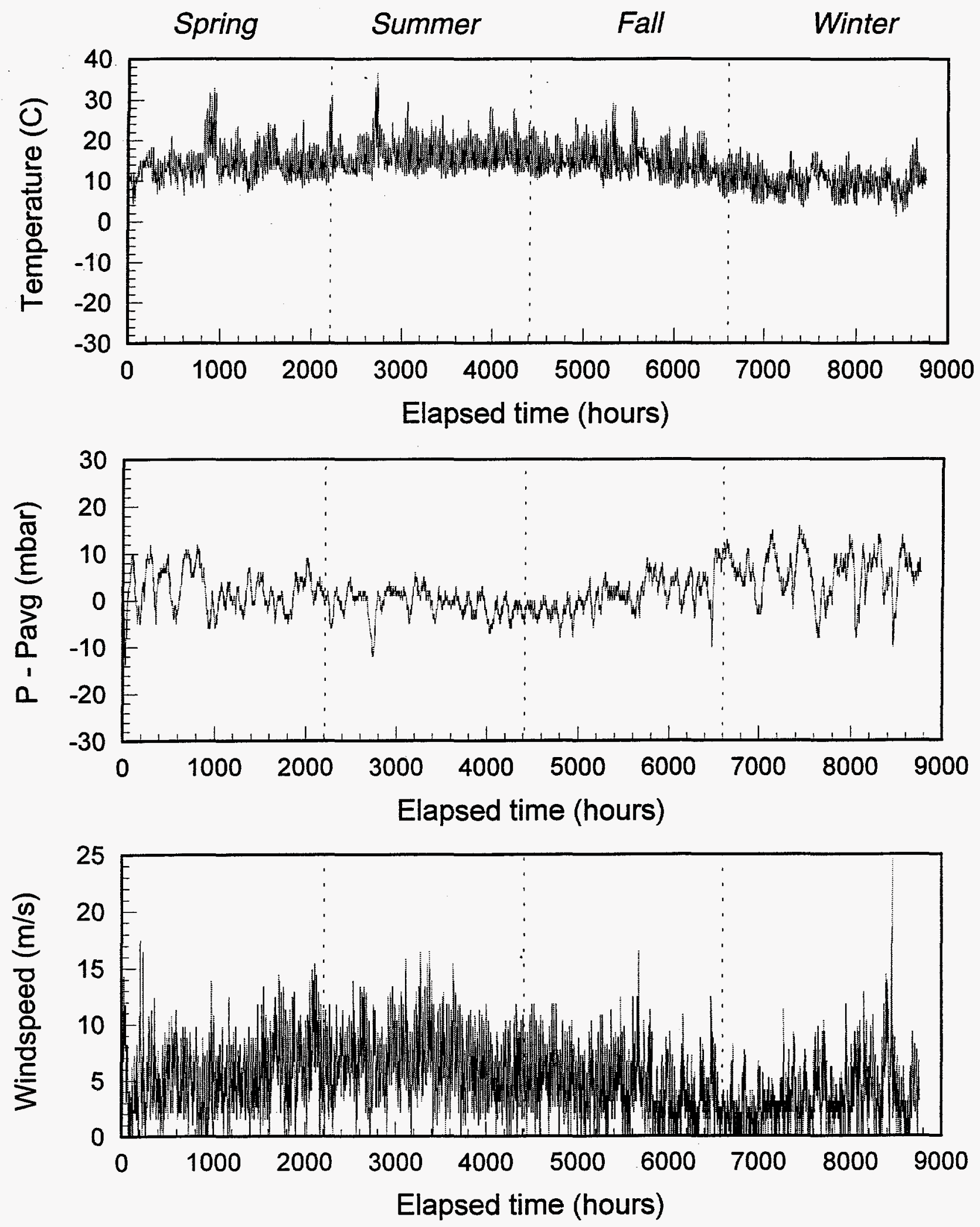

Figure A8. Climatic data for the one year period between March 1, 1989 and February 28, 1990 for San Francisco, CA. 

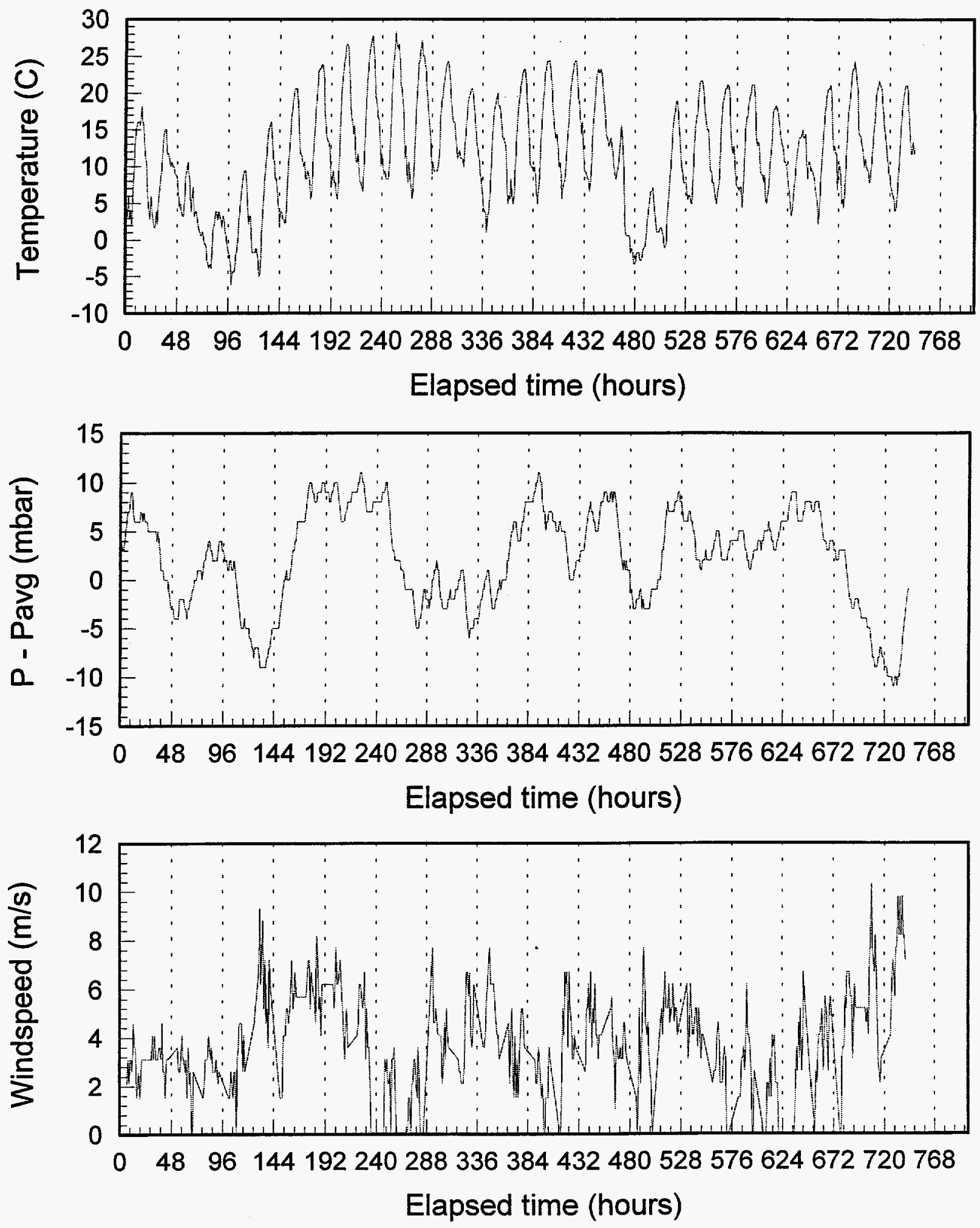

Figure A9. Climatic data for a one month period between March 1 and April 1, 1989 for Albuquerque NM 


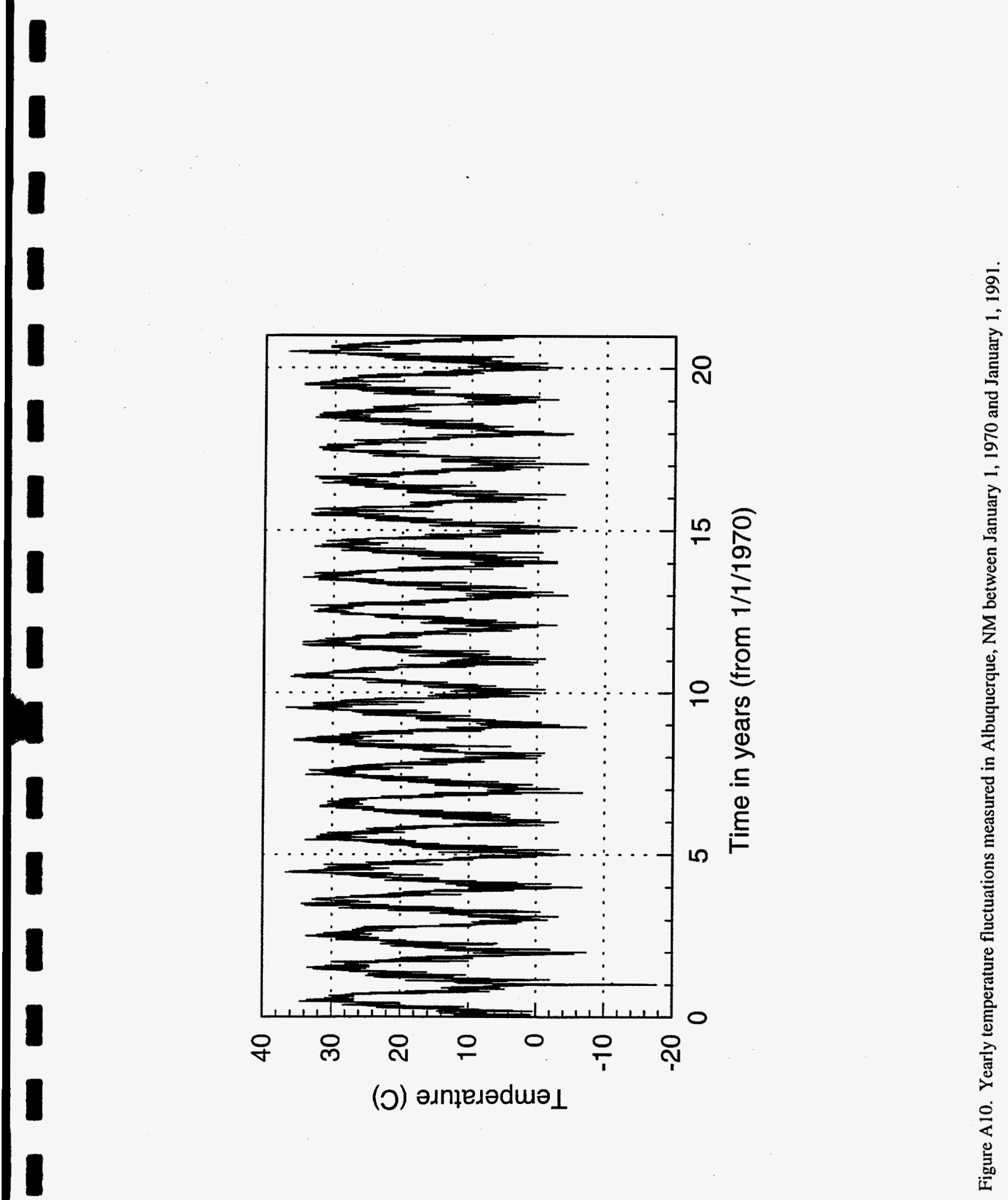




\begin{tabular}{|c|c|c|c|c|c|c|c|}
\hline & Albuquerque & Augusta & Boulder & Knoxville & Pendelton & Pocatello & San Francisco \\
\hline \multicolumn{8}{|l|}{ Temperature (C) } \\
\hline average & 14.25 & 17.63 & 10.85 & 14.01 & 11.32 & 8.89 & 13.71 \\
\hline maximum & 38.90 & 36.10 & 38.90 & 33.90 & 37.20 & 38.30 & 36.70 \\
\hline minimum & -12.20 & -8.30 & -26.70 & -17.80 & -11.10 & -15.60 & 1.10 \\
\hline std dev & 10.46 & 8.91 & 11.15 & 9.50 & 8.74 & 10.68 & 4.33 \\
\hline avg dev & 8.85 & 7.40 & 9.14 & 8.31 & 7.13 & 8.84 & 3.32 \\
\hline \multicolumn{8}{|l|}{ Pressure (mbar) } \\
\hline average & 838.62 & 1012.66 & 836.39 & 982.98 & 963.52 & 863.78 & 1017.06 \\
\hline maximum & 852.00 & 1038.00 & 852.00 & 1005.00 & 982.00 & 881.00 & 1031.00 \\
\hline minimum & 818.00 & 987.00 & 812.00 & 965.00 & 939.00 & 837.00 & 1001.00 \\
\hline std dev & 4.48 & 5.26 & 5.51 & 5.21 & 6.32 & 5.54 & 4.61 \\
\hline avg dev & 3.52 & 4.08 & 4.37 & 3.98 & 4.84 & 4.24 & 3.71 \\
\hline median & 838 & 1011 & 835 & 981 & 961 & 862 & 1015 \\
\hline \multicolumn{8}{|l|}{ Windspeed $(\mathrm{m} / \mathrm{s})$} \\
\hline average & 4.24 & 2.71 & 3.78 & 3.28 & 3.20 & 4.52 & 4.97 \\
\hline maximum & 21.10 & 17.50 & 17.00 & 16.50 & 22.10 & 17.50 & 24.70 \\
\hline minimum & 0.00 & 0.00 & 0.00 & 0.00 & 0.00 & 0.00 & 0.00 \\
\hline std dev & 2.82 & 2.14 & 2.26 & 2.10 & 2.22 & 2.81 & 3.00 \\
\hline avg dev & 2.11 & 1.74 & 1.68 & 1.71 & 1.63 & 2.21 & 2.45 \\
\hline
\end{tabular}




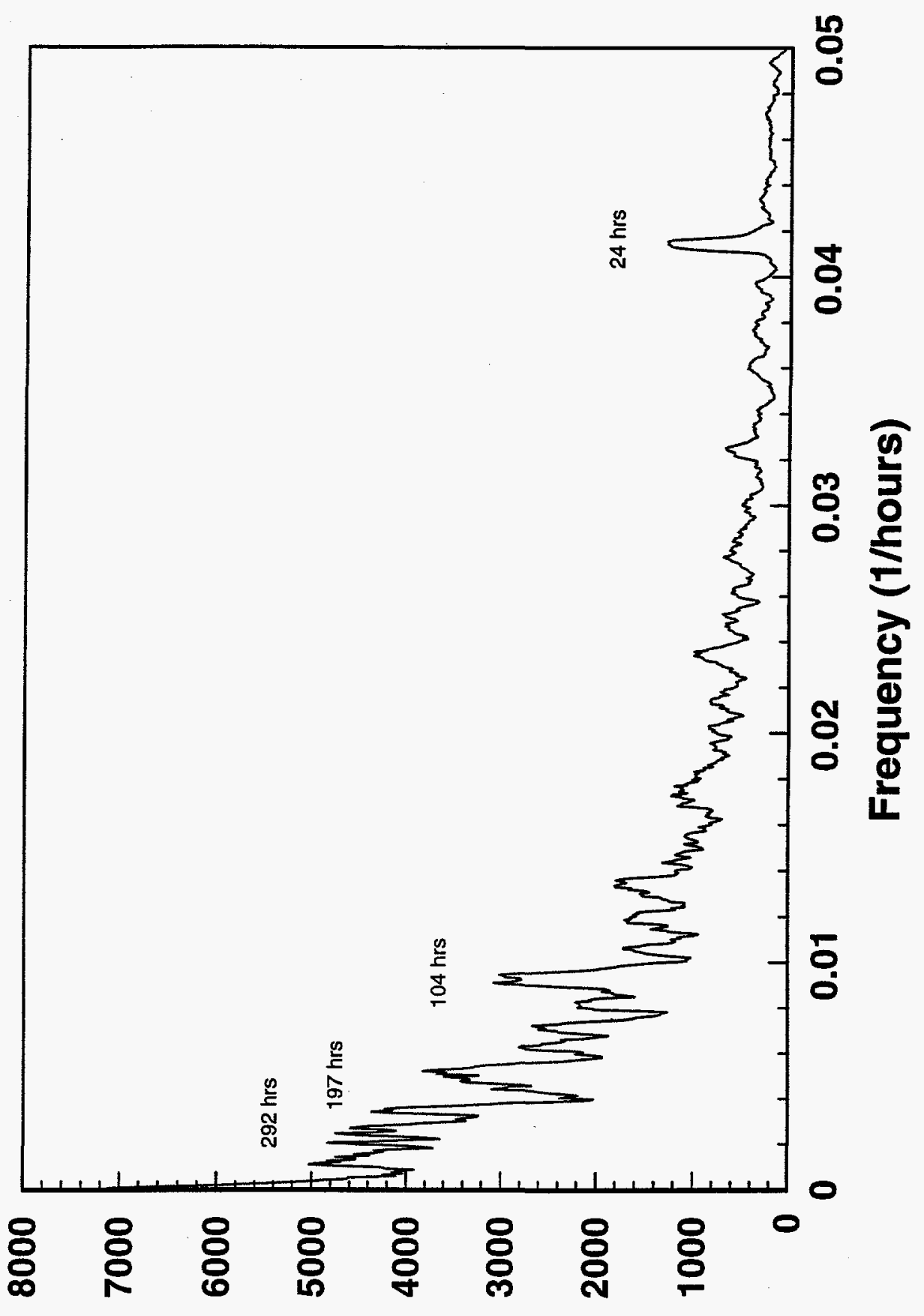

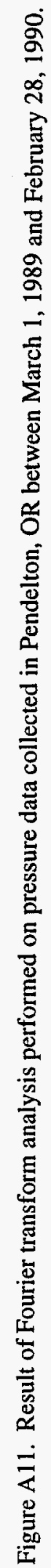




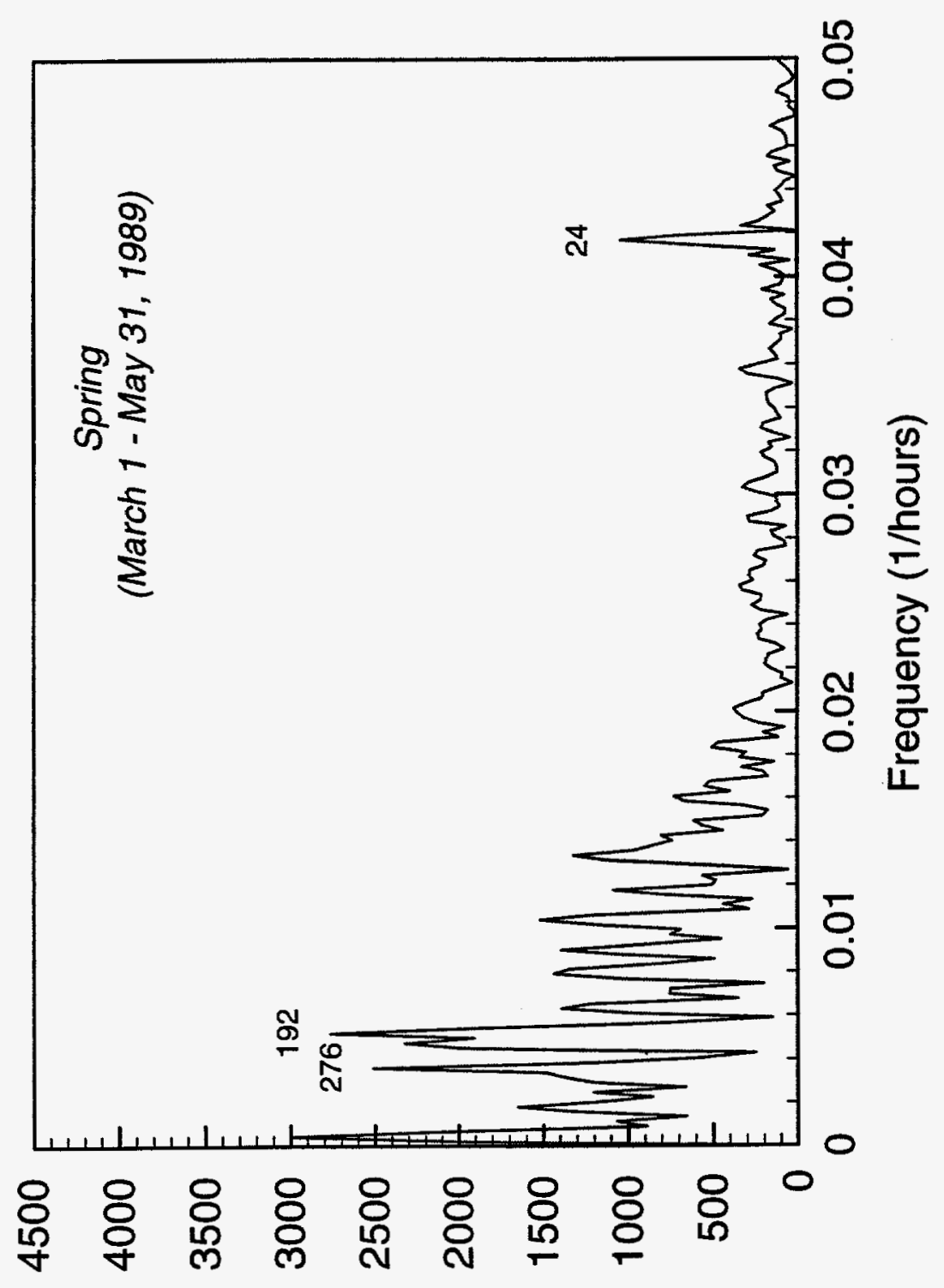

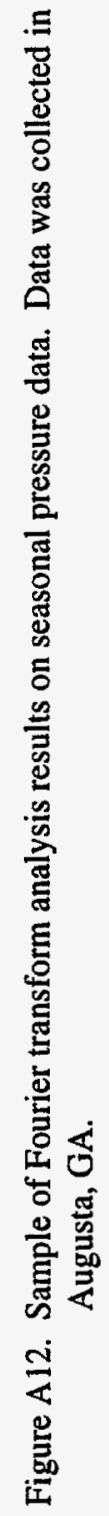




\begin{tabular}{|c|c|c|c|}
\hline & \multicolumn{3}{|c|}{ Period } \\
\hline Site & 1 Day & 8-Day & 13 Days \\
\hline Albuquerque, NM & 5.1 & 14.1 & 16.4 \\
\hline Augusta, GA & 5.2 & 16.4 & 19.0 \\
\hline Boulder, $\mathrm{CO}$ & 5.5 & 18.2 & 19.3 \\
\hline Knoxville, TN & 4.9 & 16.1 & 18.3 \\
\hline Pendelton, OR & 5.5 & 17.7 & 21.2 \\
\hline Pocatello, ID & 4.8 & 16.9 & 20.0 \\
\hline San Francisco, CA & 3.6 & 12.3 & 13.4 \\
\hline Average & 5.0 & 16.0 & 18.2 \\
\hline
\end{tabular}

Windspeeds for the different sites were reviewed to help determine if wind turbines could be effectively used to increase the extraction rate in the plenum region. (Average yearly windspeeds for the sites range from $2.7 \mathrm{~m} / \mathrm{s}$ in Augusta to $5.0 \mathrm{~m} / \mathrm{s}$ in San Francisco.) There were no strong correlations between windspeed and either pressure or temperature. There was also no distinct correlation between windspeed and time of year. Fourier transform analysis performed on the data showed a 24 hour period, but no distinct longer term periods. Review of the 24 hour periods showed winds were typically strongest in the afternoon ( 1 to $6 \mathrm{pm}$ ) and early evening periods ( $7 \mathrm{pm}$ to $12 \mathrm{am}$ ). Average windspeeds for the four 6 hour periods over the course of one year are compared with the yearly average in Table A3. Data was taken hourly in Albuquerque, NM. Other sites showed similar behavior.

\begin{tabular}{|c|c|}
\hline $\begin{array}{c}\text { Table A3. Average windspeeds (m/s) for a one year } \\
\text { period (March 1, 1989 to February 28, 1990). }\end{array}$ & Windspeed $(\mathrm{m} / \mathrm{s})$ \\
\hline Period & 4.237 \\
\hline \hline Year & 3.689 \\
1 am to $6 \mathrm{am}$ & 3.670 \\
7 am to $12 \mathrm{pm}$ & 5.075 \\
$1 \mathrm{pm}$ to $6 \mathrm{pm}$ & 4.513 \\
$7 \mathrm{pm}$ to $12 \mathrm{am}$ & \\
\hline
\end{tabular}




\section{APPENDIX B. DIFFUSIVE TRANSPORT OF VOLATILE CONTAMINANTS}

Barometric pressure and diffusion are the greatest contributors to soil gas/contaminant flow in the vadose zone. While barometric effects can be controlled to provide a net upward flow of the contaminant vapors, diffusion will naturally occur in all directions. For the barometric pumping system to work effectively, any downward flow of the contaminant vapor due to diffusion must be overcome by upward flow due to barometric pumping. There are three components to diffusive mass flux, including Knudsen diffusion, molecular diffusion, and surface migration. Surface migration only occurs when the diffusing gas is adsorbed in a mobile layer, so can be considered negligible in the unsaturated vadose zone. Knudsen diffusion dominates in media of very small pore size (Reference B1); the Knudsen diffusive flux is given by

$$
q_{K}=-D_{K} \frac{d C}{d x}
$$

where

$$
\mathrm{D}_{\mathrm{K}}=\frac{2}{3} \mathrm{r}_{\mathrm{p}}\left(\frac{8 \mathrm{RT}}{\pi \mathrm{MW}}\right)^{1 / 2}
$$

if the fraction of molecules which undergo diffuse reflections at the capillary walls is assumed to be 1 . $\mathrm{C}$ is the concentration of the diffusing gas; $\mathrm{x}$ is position; $\mathrm{r}_{\mathrm{p}}$ is pore or capillary radius; $\mathrm{T}$ is temperature; $\mathrm{R}$ is the universal gas constant; and MW is the molecular weight of the diffusing gas. Ordinary molecular diffusion dominates in media of larger pore sizes. The molecular diffusive flux of a single contaminant is:

$$
\mathrm{q}_{\mathrm{m}}=-\mathrm{D} \frac{\mathrm{dC}}{\mathrm{dx}}
$$

where $\mathrm{D}$ is the effective diffusivity constant of the contaminant through the soil pore space at specified values of temperature and pressure. If it assumed that Knudsen diffusion can be ignored if its contribution to contamination flow is at least an order of magnitude less than molecular diffusion (e.g., if $\mathrm{D}_{\mathrm{K}} \leq .1 \mathrm{D}$ ), the minimum pore radius which would satisfy this assumption can be solved for using Equation B2. This calculation was performed for chemicals typically found in the vadose zone at DOE sites (Appendix F). Results gave minimum pore radii of $4.1\left(10^{-9}\right)$ to $6.3\left(10^{-9}\right) \mathrm{m}$, (41 to 63 angstroms) which are smaller than typical pore sizes in unconsolidated media. Thus, only molecular diffusion was reviewed in depth.

Analysis of soil gas diffusion is mathematically analogous to heat transfer, where gas concentration is substituted for temperature and an effective soil diffusivity is substituted for the heat transfer constant. Two models were chosen for analysis. The first was a one-dimensional, transient planar model for a semi-infinite solid. The 
model would be appropriate for very large contaminant sources. The second is a one-dimensional transient spherical model, appropriate for a smaller source (e.g. a leaking drum or pipe line).

\section{PLANAR DIFFUSION}

The equation for one-dimensional transient heat flow in a semi-infinite solid (Reference B3) is:

$$
\frac{\partial^{2} \mathrm{C}}{\partial \mathrm{x}^{2}}=\frac{1}{\mathrm{D}} \frac{\partial \mathrm{C}}{\partial \mathrm{t}}
$$

$$
\begin{aligned}
& \text { where: } \begin{aligned}
\mathrm{C} & =\text { concentration } \\
\mathrm{t} & =\text { time } \\
\mathrm{D} & =\text { effective diffusivity constant of the contaminant through soil pores }=\frac{\mathrm{D}_{\mathrm{a}} \tau}{\varepsilon} \\
\mathrm{D}_{\mathrm{a}} & =\text { diffusivity constant of the gas in air } \\
\mathrm{x} & =\text { distance from boundary } \\
\tau & =\text { tortuosity of the medium } \\
\varepsilon & =\text { gas filled porosity of the medium }
\end{aligned}
\end{aligned}
$$

For the initial boundary conditions of $C(x, 0)=C_{i}$ and $C(0, t)=C_{o}$ for $t>0$, e.g., the source concentration must not decay significantly over time, Equation $\mathrm{B} 4$ reduces to:

$$
\frac{C(x, t)-C_{0}}{C_{i}-C_{o}}=\operatorname{erf}\left(\frac{x}{2 \sqrt{D t}}\right)
$$

Assuming that the initial concentrations, $\mathrm{C}_{\mathrm{i}}$, at any distance $\mathrm{x}$ is zero, Equation $\mathrm{B} 5$ becomes:

$$
\frac{C(x, t)-C_{0}}{-C_{o}}=\operatorname{erf}\left(\frac{x}{2 \sqrt{D t}}\right)
$$

Solving for $\mathrm{C}(\mathrm{x}, \mathrm{t})$ yields:

$$
C(x, t)=C_{0}\left\{1-\operatorname{erf}\left(\frac{x}{2 \sqrt{D t}}\right)\right\}
$$

The mass rate at which the contaminant is moving is $\mathrm{q}_{\mathrm{m}}=\mathrm{DA} \frac{\mathrm{dC}}{\mathrm{dx}}$. Differentiating Equation $\mathrm{B} 7$ with respect to $\mathrm{x}$, and substituting gives:

$$
\mathrm{q}_{\mathrm{m}}=\frac{\mathrm{D} \cdot \mathrm{A} \cdot \mathrm{C}_{0}}{\sqrt{\pi \mathrm{Dt}}} \mathrm{e}^{\left(-\mathrm{x}^{2} / 4 \mathrm{Dt}\right)}
$$

or on a per area basis, 


$$
\dot{\mathrm{m}}_{\text {contaminant, diffusion }}=\frac{\mathrm{q}_{\mathrm{m}}}{\mathrm{A}}=\frac{\mathrm{D} \cdot \mathrm{C}_{\mathrm{o}}}{\sqrt{\pi \mathrm{Dt}}} \mathrm{e}^{-\mathrm{x}^{2} / 4 \mathrm{Dt}}
$$

The minimum advective flow of the soil gas required to overcome the mass flux due to diffusion can be found by equating the two.

$$
\dot{\mathrm{m}}_{\text {contaminant, advective }} \geq \dot{\mathrm{m}}_{\text {contaminant, diffusion }}
$$

If barometric pressure oscillations are assumed to be the greatest contributor of advective flow, then the mass flux due to advective flow becomes:

$$
\dot{\mathrm{m}}_{\text {contaminant, advective }} \geq \mathrm{v}_{\text {soil gas }} \bullet \mathrm{C}(\mathrm{x}, \mathrm{t})
$$

Substituting Equations B7, B8, and B10 into Equation B9 and solving for the velocity of the soil gas, $v_{\text {soil gas, gives: }}$

$$
v_{\text {soil gas, advective }} \geq \frac{\frac{D \cdot C_{o}}{\sqrt{\pi D t}} e^{\left(-\frac{x^{2}}{2 D t}\right)}}{C_{o}+\left\{1-\operatorname{erf}\left(\frac{x}{2 \sqrt{D t}}\right)\right\}}
$$

Any advective soil gas velocity in the upward direction equal to or greater than that calculated using Equation B11 will keep contaminants from diffusing deeper into the vadose zone.

\section{SPHERICAL DIFFUSION:}

A one-dimensional transient spherical solution is (Reference B4).

$$
\frac{\partial C}{\partial t}=\frac{D}{r^{2}} \frac{\partial}{\partial r} r^{2} \frac{\partial C}{\partial t}
$$

where: $\mathrm{C}=$ concentration at radial position $\mathrm{r}$ and time $\mathrm{t}$

$D=$ effective diffusivity constant of contaminant through soil pores

$\mathbf{r}=$ radial distance

For a non-diminishing concentration source at some radial position (e.g. $\mathrm{C}_{(\mathrm{ro}, \mathrm{t})}=\mathrm{C}_{\mathrm{o}}$ for $\mathrm{t} \geq 0$, Equation $\mathrm{B} 12$ becomes: 


$$
C(r, t)=\frac{r_{0}}{r} \cdot C_{o} \cdot\left[1-\operatorname{erf} \sqrt{\frac{\left(r-r_{o}\right)^{2}}{4 D t}}\right]
$$

where: $\quad r_{0}=$ radius of constant concentration

$$
\mathrm{C}_{\mathrm{o}}=\text { source concentration }
$$

The mass rate at which the contaminant will move is given by

$$
\mathrm{q}_{\mathrm{m}}=\mathrm{D} \bullet \mathrm{A} \bullet \frac{\mathrm{dC}(\mathrm{r}, \mathrm{t})}{\mathrm{d} \mathbf{r}}
$$

Differentiating Equation B13 with respect to $r$, substituting, and then putting the results on a per area basis gives:

$$
\dot{\mathrm{m}}_{\text {contaminant, diffusion }}=\frac{\mathrm{q}_{\mathrm{r}}}{\mathrm{A}}=\frac{\mathrm{r}_{\mathrm{o}}}{\mathrm{r}^{2}} \cdot \mathrm{C}_{\mathrm{o}} \cdot \mathrm{D} \cdot \frac{\mathrm{d}}{\mathrm{dr}}\left\{\operatorname{erf} \sqrt{\frac{\left(\mathrm{r}-\mathrm{r}_{\mathrm{o}}\right)}{4 \mathrm{Dt}}}{ }^{2}\right\}
$$

Where $\dot{\mathbf{m}}_{\text {contaminant, diffusion }}=$ contaminant flux through the soil due to diffusive transport. Again, the minimum advective flow of the soil gas required to overcome the mass flux due to diffusion can be found by equating the two:

$$
\dot{\mathrm{m}}_{\text {contaminant, advective }} \geq \dot{\mathrm{m}}_{\text {contaminant, diffusion }}
$$

If barometric pressure oscillations are assumed to be the most significant contributor to upward advective movement of the soil gas, then the mass flux due to advective forces becomes:

$$
\dot{\mathrm{m}}_{\text {contaminant, advective }}=\mathrm{v}_{\text {soil gas, advective }} \bullet \mathrm{C}(\mathrm{r}, \mathrm{t})
$$

Substituting Equations B13, B14, and B16 into Equation B15 and solving for the advective velocity of the soil gas gives:

$$
v_{\text {soil gas,advective }} \geq \frac{\mathrm{D} \cdot \frac{\mathrm{d}}{\mathrm{dr}}\left\{\operatorname{erf}{\sqrt{\frac{\left(\mathrm{r}-\mathrm{r}_{\mathrm{o}}\right)}{4 \mathrm{Dt}}}}^{2}\right\}}{\mathrm{r} \bullet\left[1-\mathrm{erf}{\sqrt{\frac{\left(\mathrm{r}-\mathrm{r}_{\mathrm{o}}\right)}{4 \mathrm{Dt}}}}^{2}\right]}
$$

Thus given a radial diffusion source, any advective soil gas velocity in the upward direction equal to or greater than that calculated using Equation B17 will keep contaminants from diffusing deeper into the vadose zone. 
These models were applied to the diffusion of TCE from a planar source in Figure B1, and a spherical source in Figure B2. Required velocities are always higher near the source, where the concentration gradient is the highest. The planar source requires advective velocities ranging from $2 \times 10^{-7}$ to $7 \times 10^{-7} \mathrm{~m} / \mathrm{s}(0.017$ to $0.060 \mathrm{~m} /$ day $)$ to overcome the downward diffusion transport rate from a saturated source. The spherical source requires higher advective velocities $\left(1.8 \times 10^{-6}\right.$ to $8 \times 10^{-6} \mathrm{~m} / \mathrm{s}$, or 0.16 to $0.69 \mathrm{~m} /$ day $)$ to overcome the diffusion rate at distances to $10 \mathrm{~m}$ from the source. 

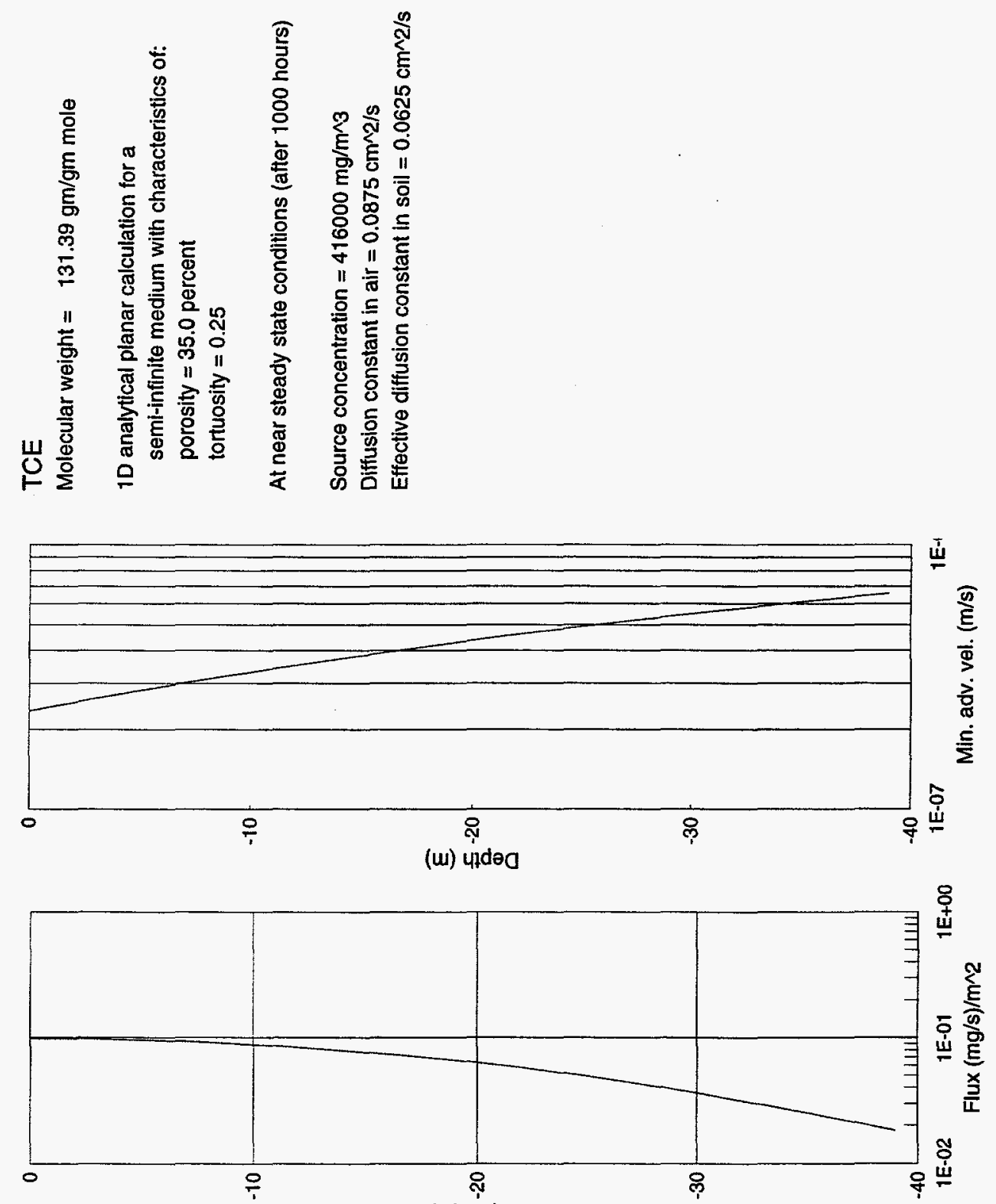

(w) uldəo
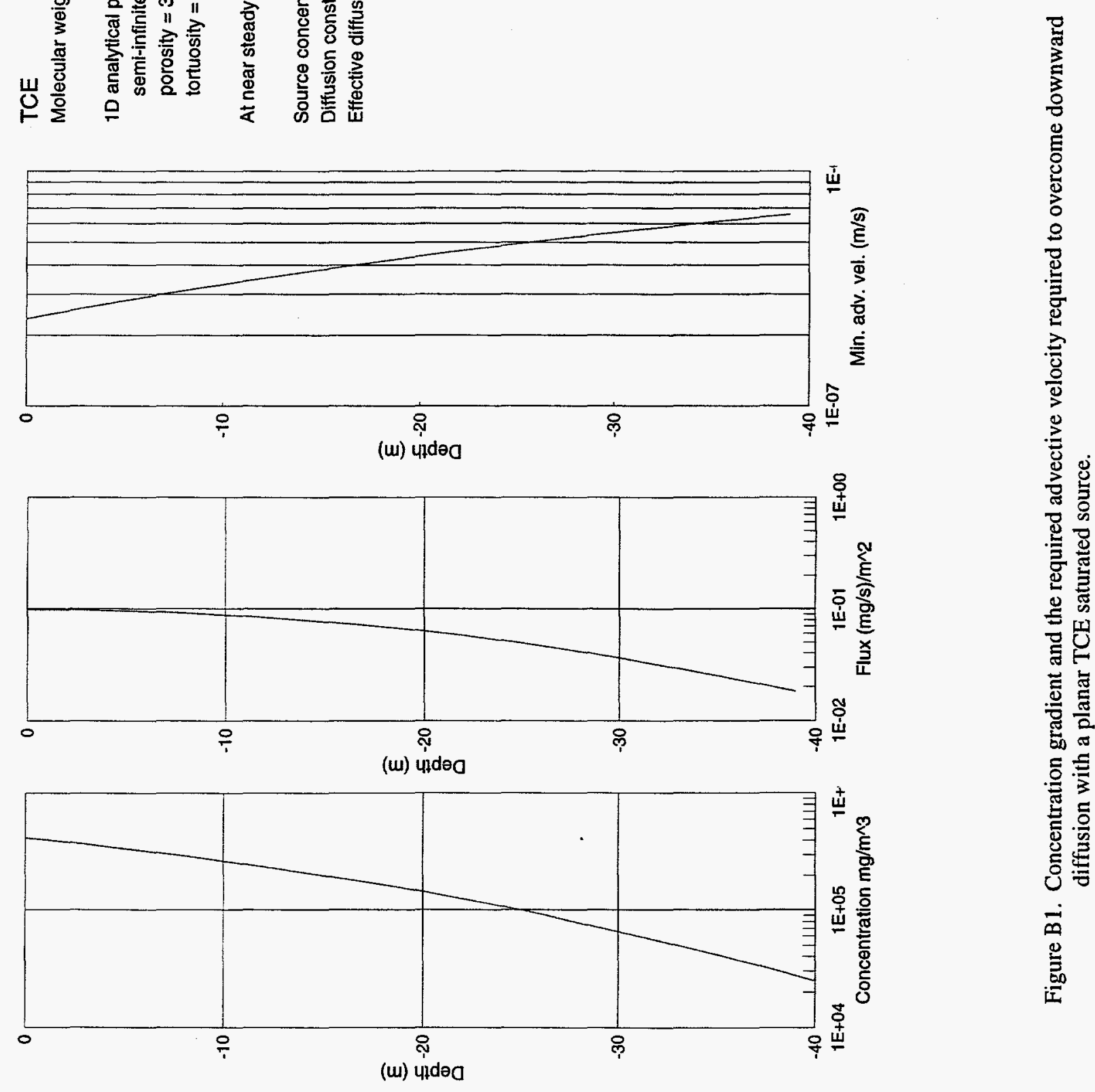

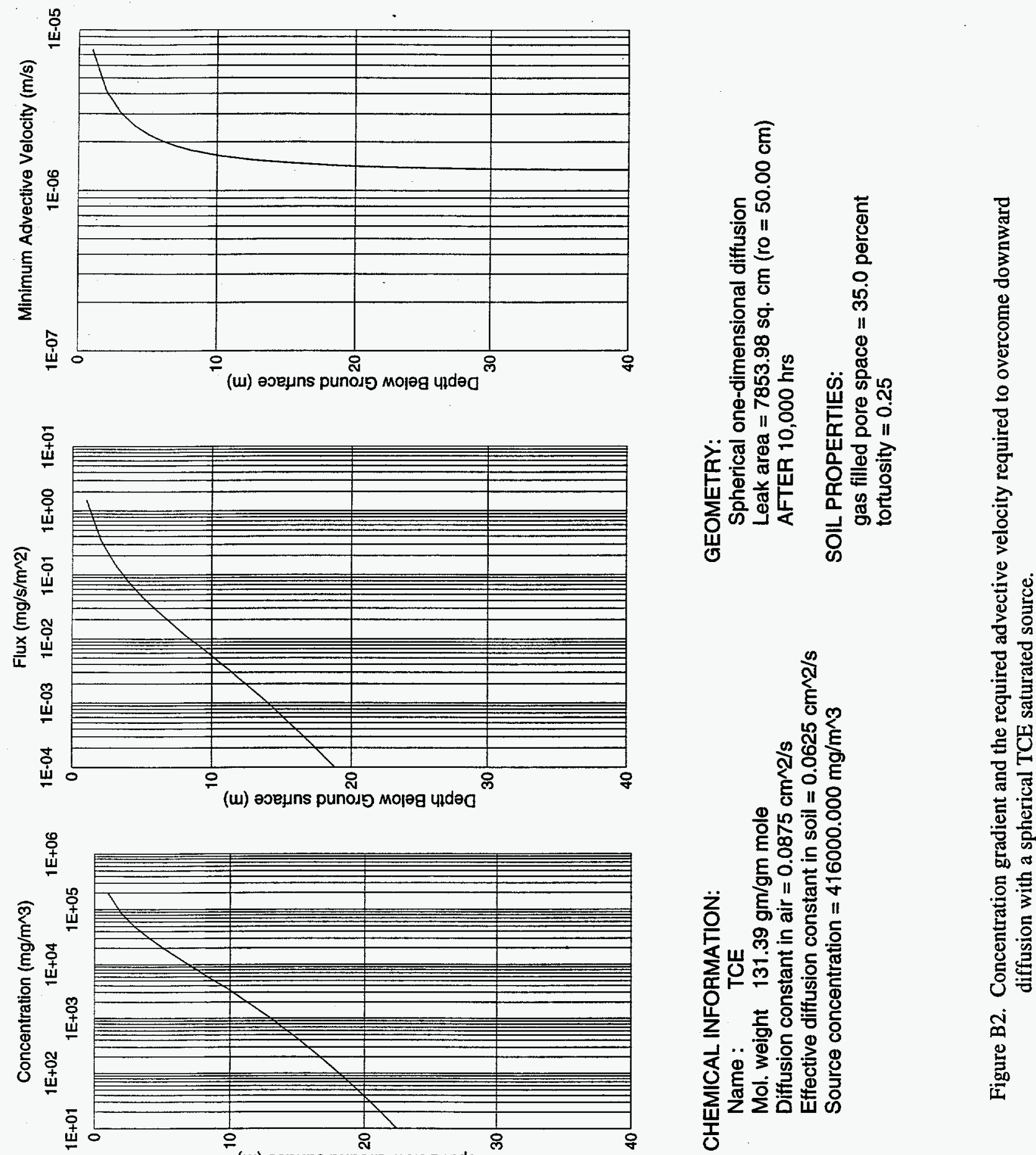

(u) әэejuns punosอ мо|әg पıdəa 


\section{APPENDIX C. DENSITY EFFECTS - THERMALLY-INDUCED GRADIENTS}

Although ground temperatures are often thought of as being constant, surface temperature variations will create substantial gradients to depths of approximately $5 \mathrm{~m}$ below the ground surface. These temperature gradients will cause cool soil gas to sink relative to warm soil gas. Thus, this advective velocity will have a positive effect on the barometric pumping system when the average surface temperature is warmer than the subsurface temperature, and a negative effect when its not. A one-dimensional heat transfer model was used to bound the magnitude of this temperature induced advective velocity.

Given a semi-infinite homogeneous medium with a sinusoidal temperature profile applied at the boundary, Davies (Reference C1) has provided the transient planar analytic solution of:

$$
\mathrm{T}(\mathrm{x}, \mathrm{t})=\mathrm{T}_{\mathrm{m}} \cdot \mathrm{e}^{-(\beta \bullet \mathrm{x})} \cdot \cos \left(\frac{2 \pi \mathrm{t}}{\mathrm{P}}-\beta \cdot \mathrm{x}-\frac{\pi}{4}\right)
$$

where:

$$
\begin{aligned}
\beta & =\sqrt{\frac{\pi \rho_{\mathrm{m}} \mathrm{c}_{\mathrm{p}}}{\mathrm{Pk}_{\mathrm{m}}}} \\
\mathrm{T}_{\mathrm{m}} & =\text { peak surface temperature variations from average } \\
\mathrm{P} & =\frac{2 \pi}{\omega}=\text { period } \\
\rho_{\mathrm{m}} & =\text { density of medium } \\
c_{\mathrm{p}} & =\text { heat capacity of medium } \\
\mathrm{k}_{\mathrm{m}} & =\text { thermal conductivity of medium }
\end{aligned}
$$

The change in density of the soil gas associated with the calculated temperature profiles at given times can be calculated using the ideal gas law, PV $=n R T$. For a given volume $\left(1 \mathrm{~m}^{3}\right)$ and pressure, the equation reduces to:

$$
n_{(T[x, t])}=n_{a m b}\left(\frac{T_{a m b}}{T_{(x, t)}}\right)
$$

where: $\left.\quad \mathbf{n}_{(\mathrm{T}}[\mathrm{x}, \mathrm{t}]\right)=$ number of moles of soil gas within one cubic meter at $\mathrm{T}(\mathrm{x}, \mathrm{t})$ and ambient pressure

$$
\mathrm{n}_{\mathrm{amb}}=\text { number of moles of soil gas in one cubic meter at ambient temperature and pressure }
$$
Multiplying $n_{(T(x, t))}$ by the molecular weight of the soil gas and dividing by the chosen volume gives the density of the soil gas at $T_{(x, t)}$ and ambient pressure. The pressure gradient in the medium due to the temperature-induced density gradient can be calculated using: 


$$
P=\rho_{f} \bullet g \bullet h
$$

where: $\rho_{\mathrm{f}}=$ density of the fluid (soil gas)

$\mathrm{g}=$ acceleration of gravity

$\mathbf{h}=$ depth of fluid (depth below ground surface)

The pressure difference due to the density gradient is then

$$
\mathrm{dP}=\mathrm{d} \rho \bullet \mathrm{g} \bullet \mathrm{h}
$$

The resultant flow can be found using the Darcy equation of flow if it is assumed that the viscosity of the gas is constant with temperature:

$$
v=\frac{\mathrm{Q}}{\mathrm{A}}=\frac{\mathrm{k} \bullet \mathrm{dP}}{\mu \cdot \mathrm{dh} \bullet \varepsilon}
$$

where: $\quad k=$ permeability of the medium

$\mu=$ viscosity of the soil gas

$\varepsilon=$ porosity of the medium

Figure A10 shows a typical temperature history for the southwestern United States. Data was recorded in Albuquerque, NM over a 21 year period beginning January 1, 1970. The average yearly temperature was approximately $17^{\circ} \mathrm{C}$; the amplitude of the yearly fluctuation was approximately $24^{\circ} \mathrm{C}$. Using this information and typical thermal properties for soil, profiles of subsurface temperature, density, pressure and velocity were calculated.

Results are shown in Figures $\mathrm{C} 1$ and $\mathrm{C} 2$. Because soil has such good insulating properties there is a significant time lag between changing surface conditions and the corresponding changes at depth. This time lag is clearly seen in each of the profiles. The maximum temperature induced velocity in this example is less than $7\left(10^{-7}\right) \mathrm{m} / \mathrm{s}$ and occurs very near the ground surface. Calculated velocities at depths between 1 and 4 meters are less than $2.5\left(10^{-8}\right) \mathrm{m} / \mathrm{s}$. These velocities are significantly less than the calculated advective velocities due to barometric pressure fluctuations (Appendix E). Review of yearly temperature fluctuations at other sites across the United States (Appendix A) shows the magnitude of the fluctuations to be approximately equal to or less than that used in the example. 


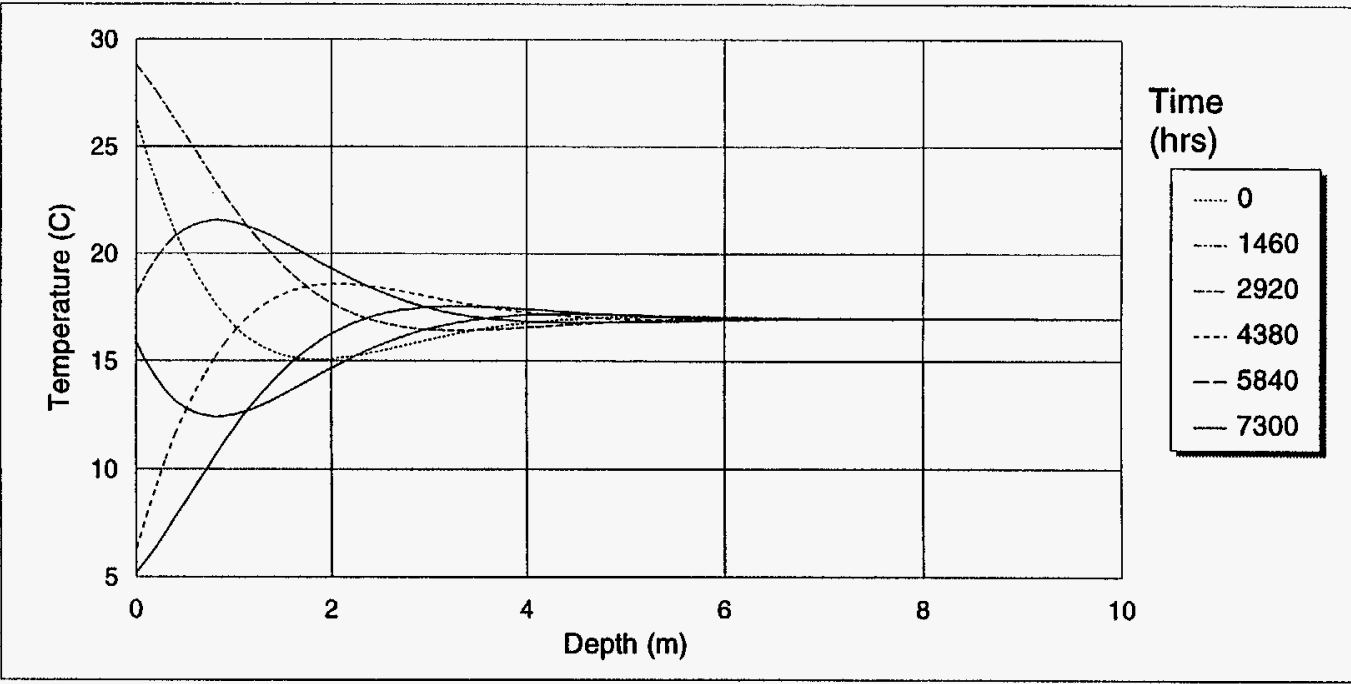

Calculation of subsurface temperature and density gradient due to cyclical atmospheric temperature changes.

Temperature profiles calculated

using an analytical equation for a

semi-infinite medium having a

sinusoidal surface temperature

imposed at the boundary.

Input included:

Average surface temperature $=17 \mathrm{C}$

Peak surface temp variation from avg $=13 \mathrm{C}$

Period used $=8760$ hours

\section{Soll properties:}

Specific heat $=1840 \mathrm{~J} / \mathrm{kg} \mathrm{K}$

Thermal conductivity $=0.52 \mathrm{~W} / \mathrm{m} \mathrm{K}$

Porosity $=0.35$

Permeabilty $=5$ darcies

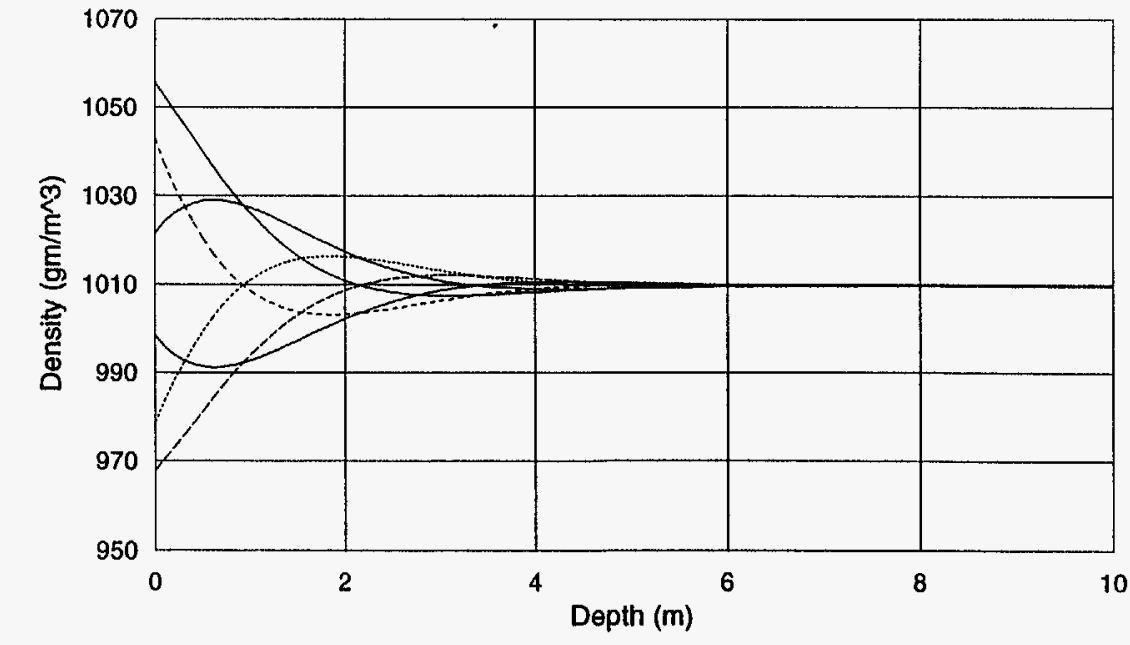

$$
\begin{gathered}
-0 \\
--0 \\
-1460 \\
--2920 \\
\cdots .4380 \\
--5840 \\
-7300
\end{gathered}
$$

Figure $\mathrm{C} 1$. Temperature and resulting gas density profiles resulting from typical annual temperature variations. 

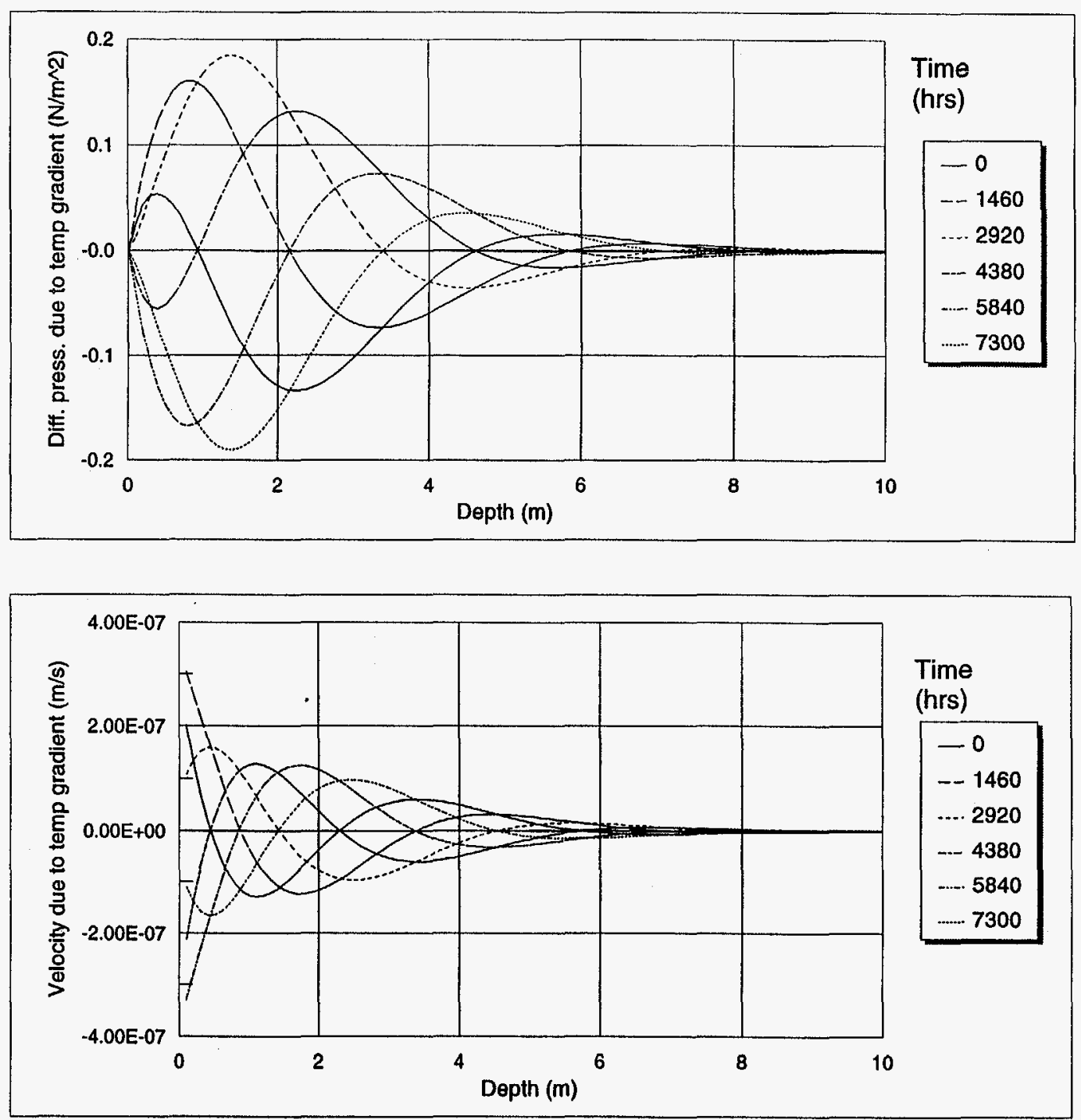

Calculation of pressure profile and velocity gradient due to cyclical atmospheric temperature changes.

Temperature profiles calculated

using an analytical equation for a

semi-infinite medium having a

sinusoidal surface temperature

imposed at the boundary.

Input included:

Average surface temperature $=17 \mathrm{C}$

Peak surface temp variation from avg $=13 \mathrm{C}$

Period used $=\mathbf{8 7 6 0}$ hours

Soll properties:

Specific heat $=1840 \mathrm{~J} / \mathrm{kg} \mathrm{K}$

Thermal conductivity $=0.52 \mathrm{~W} / \mathrm{m} \mathrm{K}$

Porosity $=0.35$

Permeabilty $=\mathbf{5}$ darcies

Soil gas properties:

Viscosity $=0.0000179 \mathrm{Ns} / \mathrm{m}^{\wedge} 2$

Molecular weight $=29 \mathrm{gm} / \mathrm{gm}$ mole

Ambient pressure $=840.00 \mathrm{mbar}$

Figure C2. Density-induced differential pressure gradient, and advective flow velocity required to overcome this gradient, given the temperature variation in Figure $\mathrm{Cl}$. 


\section{APPENDIX D. DENSITY EFFECTS - CONCENTRATION GRADIENTS}

Gravity is another advective force that will cause soil gas movement. Most contaminant vapors are more dense than air, so will be pulled deeper into the soil by gravity. The velocity associated with the gravitational force given a concentration profile can be estimated by first calculating the density profile of the contaminant/air mixture using the ideal gas law, then calculating the pressure difference between the contaminated and non-contaminated conditions (e.g., account for buoyancy), and finally using Darcy's equation-of-flow to calculate the velocity. Figure D1 shows a schematic of the model used to calculate the gravitational effect on the contaminant profile. The pressure difference between the contaminated and non-contaminated conditions, $\mathrm{dP}_{\mathrm{n}}$, is:

$$
\begin{aligned}
& \mathrm{dP}_{\mathrm{n}}=\mathrm{P}_{\text {pcon }}-\mathrm{P}_{\text {pair }} \\
& =\left\{\mathrm{P}_{\mathrm{C}_{\mathrm{o}}}+\sum_{\mathrm{i}=1, \mathrm{n}}\left(\underset{\mathrm{mix}}{\rho_{\mathrm{i} \text { avg }}} \bullet \mathrm{g} \bullet \mathrm{dh} \mathrm{h}_{\mathrm{i}}\right)\right\}-\left\{\mathrm{P}_{\mathrm{air}}+\sum_{\mathrm{i}=1, \mathrm{n}}\left(\rho_{\mathrm{i}, \text { air }} \bullet \mathrm{g} \bullet \mathrm{dh} \mathrm{i}_{\mathrm{i}}\right)\right\}
\end{aligned}
$$

where:

$$
\begin{aligned}
\mathrm{P}_{\text {pcon }} & =\text { pressure in contaminated medium } \\
\mathrm{P}_{\text {pair }} & =\text { pressure in non-contaminated medium } \\
\mathrm{P}_{\mathrm{Co}} & =\text { pressure at concentration source } \\
\rho_{\mathrm{avg}, \mathrm{mix}} & =\text { average density of pore gas mixture }=\left(\rho_{\mathrm{i}, \mathrm{mix}}+\rho_{\mathrm{i}-1, \mathrm{mix}}\right) / 2 \\
\mathrm{~g} & =\text { acceleration of gravity } \\
\mathrm{dh} & =\text { change of depth of fluid } \\
\rho_{\text {air }} & =\text { density of air }
\end{aligned}
$$

If the effect of the contaminant vapor/air mixture above the liquid mass is ignored, e.g., if $\rho_{\text {liquid }} \gg \rho_{\text {air }}$, then $\mathrm{P}_{\mathrm{C}_{\mathrm{o}}}=\mathrm{P}_{\mathrm{air}}$. Thus

$$
\mathrm{dP}_{\mathrm{n}}=\sum_{\mathrm{i}=1, \mathrm{n}}\left(\rho_{\mathrm{i}_{\text {avg,mix }}}-\rho_{\mathrm{i}_{\text {air }}}\right) \cdot \mathrm{g} \bullet \mathrm{dh}_{\mathrm{i}}
$$

The pore gas velocity due to gravity, $v_{n}$, is calculated using Darcy's equation of flow:

$$
\mathrm{v}_{\mathrm{n}}=\frac{\mathrm{Q}_{\mathrm{n}}}{\mathrm{A}_{\mathrm{n}}}=\frac{\mathrm{k} \bullet\left(\mathrm{dP}_{\mathrm{n}-1}-\mathrm{dP}_{\mathrm{n}}\right)}{\mu_{\mathrm{n}} \bullet \mathrm{dh}_{\mathrm{n}} \bullet \varepsilon}
$$


where: $\mathrm{k}=$ soil permeability

$$
\varepsilon=\text { soil porosity }
$$

$$
\mu_{\mathrm{n}}=\text { fluid viscosity, assume } \mu_{\mathrm{n}} \approx \mu_{\text {air }}
$$

substituting Equation D1 into Equation D2 gives:

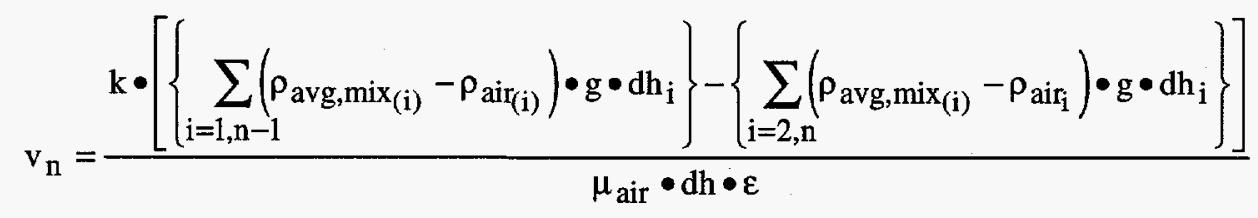

The most heavily contaminated soil gas will have the highest velocity. Figure D2 depicts profiles given spherical diffusion from a liquid TCE contaminant source. The magnitude of the profiles was calculated for points above and below a contaminant source. The initial concentration profiles were calculated using analytic heat transfer solutions assuming a homogeneous, isotropic medium and neglecting the effect of gravity (Appendix B). Figure D3 shows similar profiles for a model using planar diffusion calculations (Appendix B). Resulting velocities are dependent on the molecular weight of the contaminant and the concentration profile; the maximum concentration, $\mathrm{C}_{\mathrm{o}}$, was calculated as a function of the contaminant's vapor pressure. This is a worst case assumption. In reviewing common contaminants at DOE sites (Appendix F), it was found that contaminants having the highest initial concentrations and molecular weights include trichloroethylene, 1,1,1-Trichloroethane, tetrachloroethylene, carbon tetrachloride, and chloroform. To bound the effect of gravity on the barometric pumping system, calculations were performed for TCE assuming a worst case of planar diffusion with the maximum contaminant vapor concentration calculated using the contaminants vapor pressure at ambient conditions.

In general, the soil gas velocities required to overcome these transport rates are less than $0.2 \times 10^{-6} \mathrm{~m} / \mathrm{s}$ for the spherical source several meters from the source. For the planar source (because its concentration drops off more slowly than is the case with spherical diffusion) soil gas velocities on the order of 0.3 to $0.7 \times 10^{-6} \mathrm{~m} / \mathrm{s}$ are required to overcome density-induced transport. 


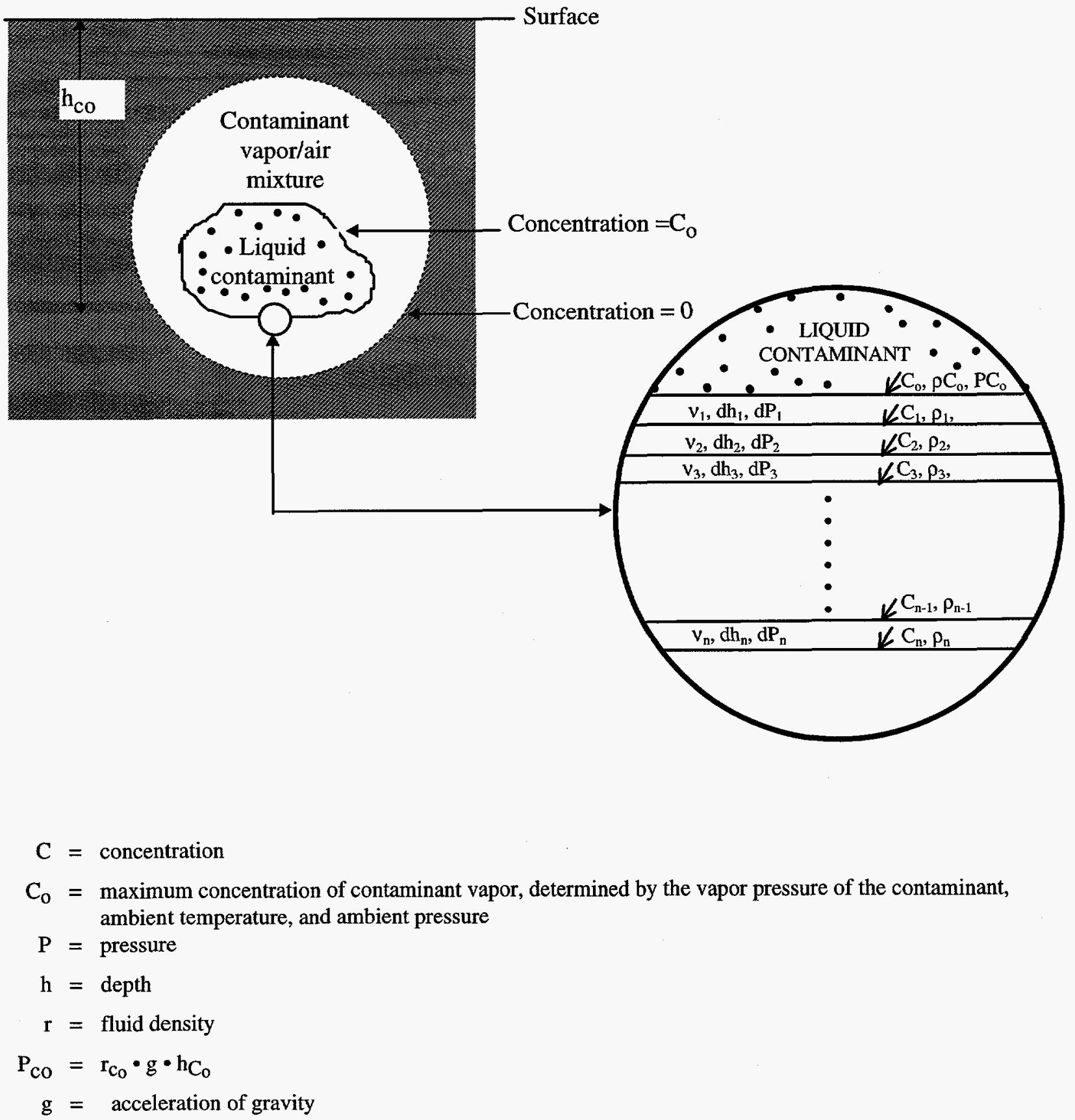

Figure D1. Model used to calculate gravitational effect on contaminant profile. 

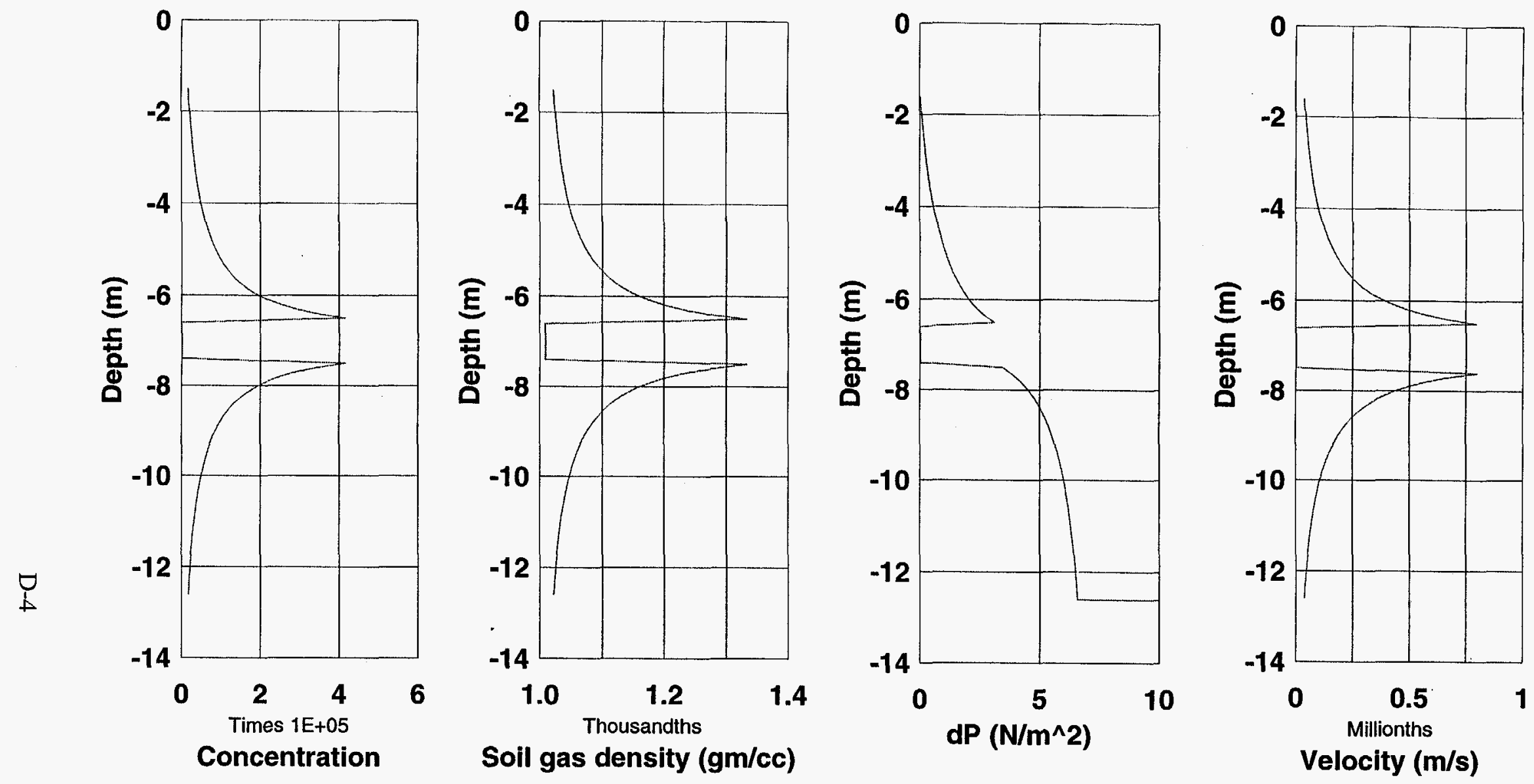

Calculation of velocity gradient due to density changes caused by a concentration profile. Concentration profile calculated using a 1D spherical analytical solution for a semi-infinite medium. Depth to center of contaminant source $=7.0 \mathrm{~m}$, radius of source $=0.5 \mathrm{~m}$

Chemical Contaminant: TCE

Molecular weight $=131.4, \mathrm{gm} / \mathrm{gm}$ mole

Density $=1.46 \mathrm{gm} / \mathrm{cc}$

Source concentration $=416000 \mathrm{mg} / \mathrm{m}^{\wedge} 3$

Diffusion constant in air $=0.0875 \mathrm{~cm}^{\wedge} 2 / \mathrm{s}$

Effective diffusion constant in soil $=0.0625 \mathrm{~cm}^{\wedge} 2 / \mathrm{s}$

\section{Soil Properties:}

Permeability $=5.0$ darcies

Porosity $=35.0$ percent

Tortuosity $=0.3$

Ambient temperature $=14.0 \mathrm{C}$

Ambient pressure $=83000 \mathrm{~N} / \mathrm{m}^{\wedge} 2$

at near steady-state conditions (after 1000 hours)

Figure D2. Calculated profiles due to density effects caused by concentration gradients assuming radial diffusion. 

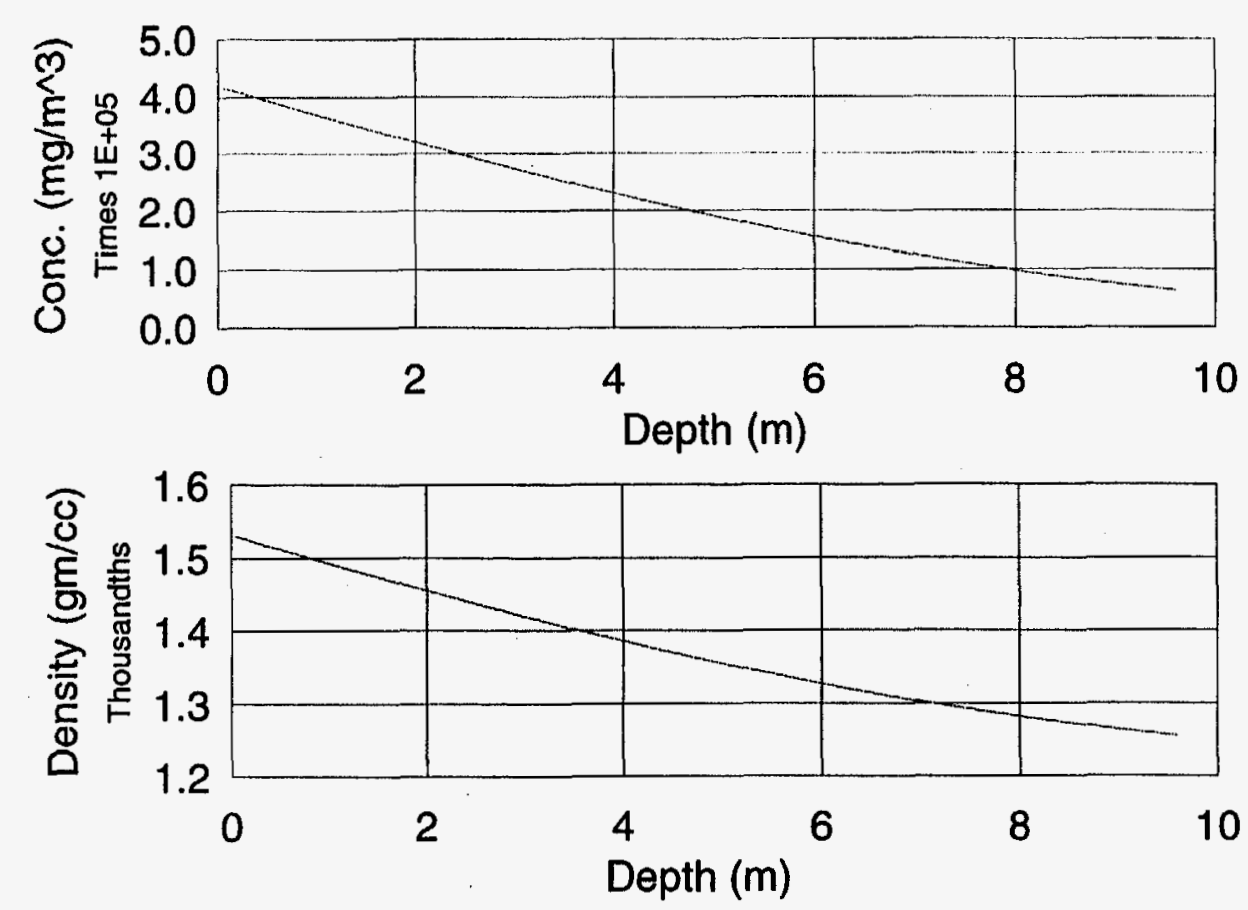

崩
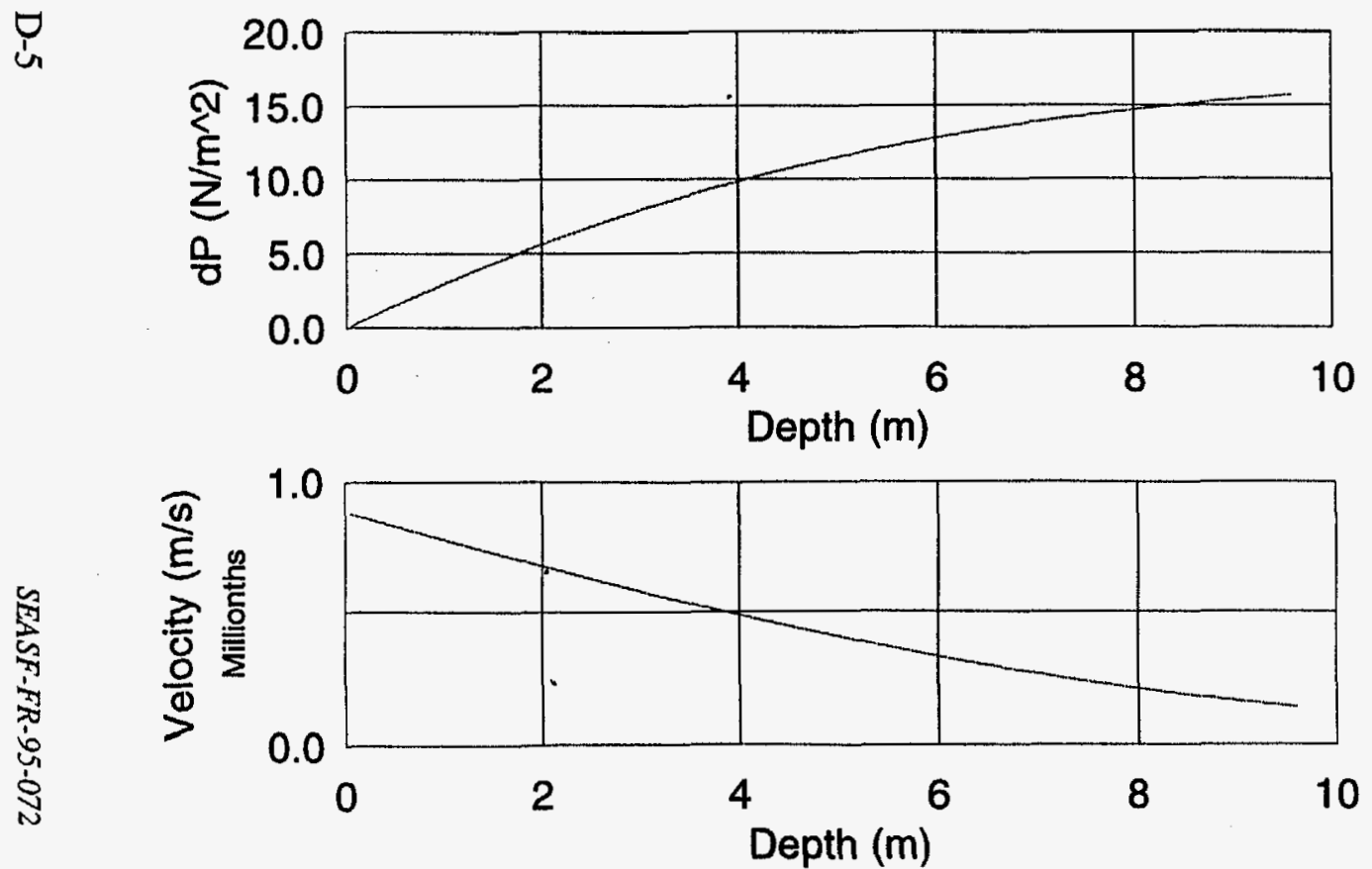

Calculation of velocity gradient due to density changes caused by a concentration profile. Concentration profile calculated using a 1D planar analytical solution for a semi-infinite medium.

Chemical Contaminant: TCE

Molecular weight of contaminant $=131.39 \mathrm{gm} / \mathrm{gm}$ mole

Density $=1.4600 \mathrm{gm} / \mathrm{cc}$

Source concentration $=416000 \mathrm{mg} / \mathrm{m}^{\wedge} 3$

Diffusion constant in air $=0.0875 \mathrm{~cm}^{\wedge} 2 / \mathrm{s}$

Effective diffusion constant in soil $=0.0625 \mathrm{~cm}^{\wedge} 2 / \mathrm{s}$

Soil Properties:

Permeability $=5.0$ darcies

Porosity $=35.0$ percent

Tortuosity $=0.3$

ADD AMB P AND T

at near steady-state conditions (after 1000 hours)

Figure D3. Calculated profiles due to density effects caused by concentration gradients assuming planer diffusion. 


\section{APPENDIX E. BAROMETRIC PUMPING}

The key to the success of the barometric pumping system is naturally occurring cyclical barometric pressure fluctuations. These fluctuations cause the soil pore gas to move in an oscillatory fashion. The barometric pumping system design accentuates the upward movement toward the surface. If this upward movement is sufficient to overcome those processes which drive contaminants downward (diffusion, gravity, and other advective processes), the soil will, over time, be remediated. An analytic model was developed to predict the effect of barometric pumping on the pore gas.

The model assumes an isotropic, homogeneous medium of some finite thickness. An impermeable barrier, such as a clay layer or the water table, is located at the bottom of the medium, and a sinusoidal pressure is applied to the surface. Gravitational effects are neglected.

\section{The Model}

The flow is modeled with the standard differential equation for one dimensional porous flow in a uniform medium:

$$
\frac{\delta \mathrm{p}(\mathrm{x}, \mathrm{t})}{\delta \mathrm{t}}=\alpha \frac{\delta^{2} \mathrm{p}(\mathrm{x}, \mathrm{t})}{\delta \mathrm{x}^{2}}, \quad 0<\mathrm{x}<\mathrm{L},-\infty<\mathrm{t}<\infty
$$

where $p(x, t)$ is the pressure of the pore gas at time $t$, at a depth $x$ from the surface, and $\alpha$ is the uniform diffusivity of the medium. The boundary condition at the impermeable barrier is zero vertical pore gas velocity, which requires that the pressure gradient go to zero in accordance with

$$
\lim _{x \rightarrow L} \frac{\delta p(x, t)}{\delta x}=0, \quad-\infty<t<\infty
$$

The other boundary condition is the sinusoidal surface pressure, with the form

$$
\mathrm{p}(0, \mathrm{t})=\mathrm{p}_{\mathrm{o}}+\Delta \mathrm{p} \cos \left(\frac{2 \pi \mathrm{t}}{\mathrm{T}}\right), \quad-\infty<\mathrm{t}<\infty
$$

with $p_{0}$ being the mean pressure, $\Delta p$ the amplitude and $T$ the period of the pressure oscillation.

The use of complex functions facilitates the solution. The complex function $q(x, t)$ is defined such that $p(x, t)$ is the real part of $q(x, t)$ and, 


$$
\begin{aligned}
& \frac{\delta \mathrm{q}(\mathrm{x}, \mathrm{t})}{\delta \mathrm{t}}=\alpha \frac{\delta^{2} \mathrm{q}(\mathrm{x}, \mathrm{t})}{\delta \mathrm{x}^{2}}, \quad 0<\mathrm{x}<\mathrm{L}, \quad-\infty<\mathrm{t}<\infty, \\
& \lim _{\mathrm{x} \rightarrow \mathrm{L}} \frac{\delta \mathrm{q}(\mathrm{x}, \mathrm{t})}{\delta \mathrm{x}}=0, \quad-\infty<\mathrm{t}<\infty, \text { and } \\
& \mathrm{q}(0, \mathrm{t})=\mathrm{p}_{\mathrm{O}}+\Delta \mathrm{p} \exp \left(\mathrm{i} \frac{2 \pi \mathrm{t}}{\mathrm{T}}\right), \quad-\infty<\mathrm{t}<\infty .
\end{aligned}
$$

These equations are satisfied by

$$
\mathrm{q}(\mathrm{x}, \mathrm{t})=\mathrm{p}_{\mathrm{o}}+\Delta \mathrm{p} \frac{\cosh [\mathrm{K}(\mathrm{L}-\mathrm{x})(1+\mathrm{i})]}{\cosh [\mathrm{KL}(1+\mathrm{i})]} \exp \left(\mathrm{i} \frac{2 \pi \mathrm{t}}{\mathrm{T}}\right), \quad 0<\mathrm{x}<\mathrm{L}, \quad-\infty<\mathrm{t}<\infty,
$$

where

$$
\mathrm{K}=\sqrt{\frac{\pi}{\alpha \mathrm{T}}}
$$

because

$$
\begin{aligned}
& \frac{\delta q(x, t)}{\delta t}=i\left(\frac{2 \pi}{T}\right) \Delta p \frac{\cosh [K(L-x)(1+i)]}{\cosh [K L(1+i)]} \exp \left(i \frac{2 \pi t}{T}\right), 0<x<L, \quad-\infty<t<\infty, \\
& \alpha \frac{\delta q^{2}(x, t)}{\delta x^{2}}=i 2 k^{2} \alpha \Delta p \frac{\cosh [K(L-x)(1+i)]}{\cosh [K L(1+i)]} \exp \left(i \frac{2 \pi t}{T}\right)=\frac{\delta q(x, t)}{\delta t}, \quad 0<x<L, \quad-\infty<t<\infty, \\
& \frac{\delta q(x, t)}{\delta x}=-(1+i) k \Delta p \frac{\sinh [K(L-x)(1+i)]}{\cosh [K L(1+i)]} \exp \left(i \frac{2 \pi t}{T}\right), \quad 0<x<L, \quad-\infty<t<\infty,
\end{aligned}
$$

and the boundary conditions are satisfied.

To find the pressure field $\mathrm{q}-\mathrm{p}_{\mathrm{o}}$ is manipulated into polar form so that

$$
q=p_{o}+\left|q-p_{o}\right| \exp \left[i \arg \left(q-p_{o}\right)\right]
$$

and

$$
p=p_{o}+\left|q-p_{o}\right| \cos \left[\arg \left(q-p_{o}\right)\right]
$$


Using the identity

$$
\begin{aligned}
& |\cosh [y(1+i)]|^{2}=\cosh ^{2} y \cos ^{2} y+\sinh ^{2} y \sin ^{2} y=-1+\cosh ^{2} y+\cos 2 y=\frac{\cosh 2 y+\cos 2 y}{2}, \\
& \left|q(x, t)-p_{o}\right|=\Delta p \sqrt{\frac{\cosh [2 K(L-x)]+\cos [2 K L(L-x)]}{\cosh [2 K L]+\cos [2 K L]}}
\end{aligned}
$$

and

$$
\arg \left(\mathrm{q}-\mathrm{p}_{\mathrm{o}}\right)=\frac{2 \pi \mathrm{T}}{\mathrm{t}}+\theta-\beta
$$

h

$$
\begin{aligned}
& \theta=\frac{3 \pi}{2} \text { if } \cos [\mathrm{K}(\mathrm{L}-\mathrm{x})]=0 \text { and } \sin [\mathrm{K}(\mathrm{L}-\mathrm{x})]<0 \\
& \theta=\arctan \{\tanh [\mathrm{K}(\mathrm{L}-\mathrm{x})] \bullet \tan [(\mathrm{K}(\mathrm{L}-\mathrm{x})]\} \text { if } \cos [(\mathrm{K}(\mathrm{L}-\mathrm{x})]>0 \\
& \theta=\pi+\arctan \{\tanh [(\mathrm{K}(\mathrm{L}-\mathrm{x})] \bullet \tan [(\mathrm{K}(\mathrm{L}-\mathrm{x})]\} \text { if } \cos [(\mathrm{K}(\mathrm{L}-\mathrm{x})]<0
\end{aligned}
$$

and

$$
\begin{aligned}
& \beta=\frac{\pi}{2} \text { if } \cos (\mathrm{KL})=0 \text { and } \sin (\mathrm{KL})>0 \\
& \beta=\frac{3 \pi}{2} \text { if } \cos (\mathrm{KL})=0 \text { and } \sin (\mathrm{KL})<0 \\
& \beta=\arctan \{\tanh (\mathrm{KL}) \cdot \tan (\mathrm{KL}\} \text { if } \cos (\mathrm{KL})>0 \\
& \beta=\pi+\arctan \{\tanh (\mathrm{KL}) \cdot \tan (\mathrm{KL})\} \text { if } \cos (\mathrm{KL})<0
\end{aligned}
$$

and the arctan function is defined to have the range $(-\pi / 2, \pi / 2)$.

Similarly, the flux can be calculated as:

$$
\frac{\delta \mathrm{p}}{\delta \mathrm{x}}=\left|\frac{\delta \mathrm{q}}{\delta \mathrm{x}}\right| \cos \left[\arg \left(\frac{\delta \mathrm{q}}{\delta \mathrm{x}}\right)\right]
$$


where

$$
\begin{aligned}
\frac{\delta q}{\delta x} & =k \Delta p \sqrt{2 \frac{\cosh [2 K(L-x)]-\cos [2 K(L-x)]}{\cosh [2 K L]+\cos [2 K L]}} \text { and } \\
\arg \left(\frac{\partial q}{\partial t}\right) & =\frac{2 \pi t}{T}+\frac{5 \pi}{4}+\gamma-\beta
\end{aligned}
$$

and

$$
\begin{aligned}
& \gamma=\pi / 2 \text { if } \cos [K(L-x)\}=0 \text { and } \sin [K(L-x)]>0 \\
& \gamma=3 \pi / 2 \text { if } \cos [K(L-x)]=0 \text { and } \sin [K(L-x)]<0 \\
& \gamma=\arctan \left\{\frac{\tan [K(L-x)]}{\tanh [K(L-x)]} \text { if } \cos [K(L-x)]>0\right. \\
& \gamma=\pi+\arctan \left\{\frac{\tan [K(L-x)]}{\tanh [K(L-x)]} \text { if } \cos [K(L-x)]<0\right.
\end{aligned}
$$

Given the calculated flux histories, corresponding velocities can be calculated using Darcy's law:

$$
v_{\text {soilgas }}=\frac{\mathrm{Q}}{\mathrm{A}}=\frac{\mathrm{k}}{\mu \varepsilon} \frac{\delta \mathrm{P}}{\delta \mathrm{x}}
$$

$$
\begin{aligned}
\text { where } \mathrm{k} & =\text { soil permeability } \\
\mu & =\text { soil gas viscosity } \\
\varepsilon & =\text { soil porosity }
\end{aligned}
$$

\section{CaIculational Results}

Appendix A discusses recorded magnitudes and periods of barometric pressure fluctuations. Using this information, typical alluvial soil properties, and an assumed depth to the impermeable layer, a series of calculations was performed to show how soil velocities differ with respect to typical pressure fluctuations. Figures E1 through E3 show these results.

Calculated pressure responses with depth follow the applied surface pressure more closely as the period of the pressure fluctuation increases. While the overall pressure change at a given depth is greater for the longer periods, the associated velocities are smaller, e.g., the time required for a given pressure difference to occur is longer. Maximum velocities associated with the daily fluctuations range from $2\left(10^{-}-6\right) \mathrm{m} / \mathrm{s}$ at 80 meters below ground surface (bgs) to $8\left(10^{-6}\right) \mathrm{m} / \mathrm{s}$ at 5 meters bgs. 

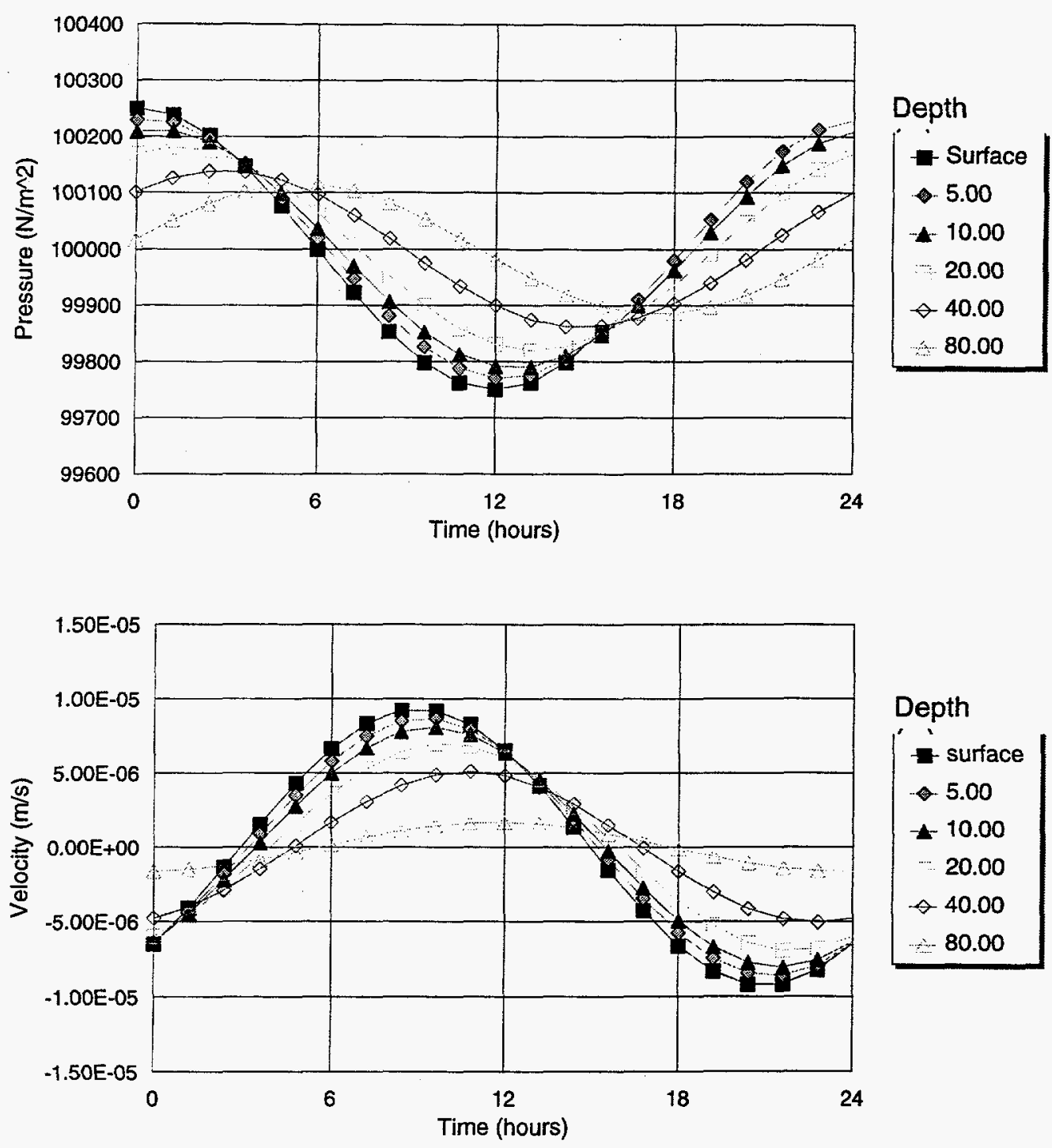

Calculated subsurface pressures and velocities given an imposed sinusoidal surface pressure on a porous medium of some finite thickness.

Medium characteristics:

Permeabilty $=10.0$ darcies

Porosity $=35$ percent

Pore gas characteristics:

Viscosity $=0.0000179 \mathrm{Ns} / \mathrm{m}^{\wedge} 2$

Molecular weight $=29.00 \mathrm{gm} / \mathrm{gm}$ mole
Surface conditions:

Average surface pressure $=100000 \mathrm{~N} / \mathrm{m}^{\wedge} 2$

Peak surface pressure variation from avg $=250 \mathrm{~N} / \mathrm{m}^{\wedge} 2$

Period used $=24$ hours

Depth to impermeable layer $=100.0 \mathrm{~m}$

Figure E1. Pressure and velocity fluctuations with time and depth, based on a pressure amplitude of $5 \mathrm{mbar}(500 \mathrm{~N} / \mathrm{m} 2)$ over a 24 hour period. 


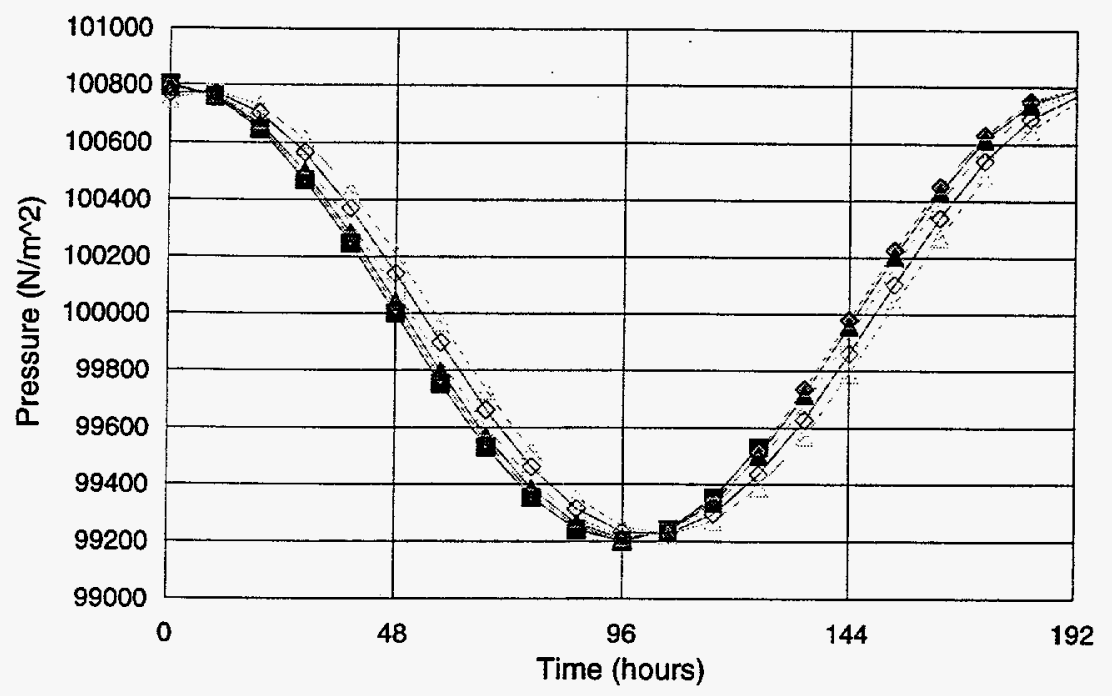

Depth

$\left[\begin{array}{c}- \text { Surface } \\ -5.00 \\ -10.00 \\ 20.00 \\ +40.00 \\ 80.00\end{array}\right.$

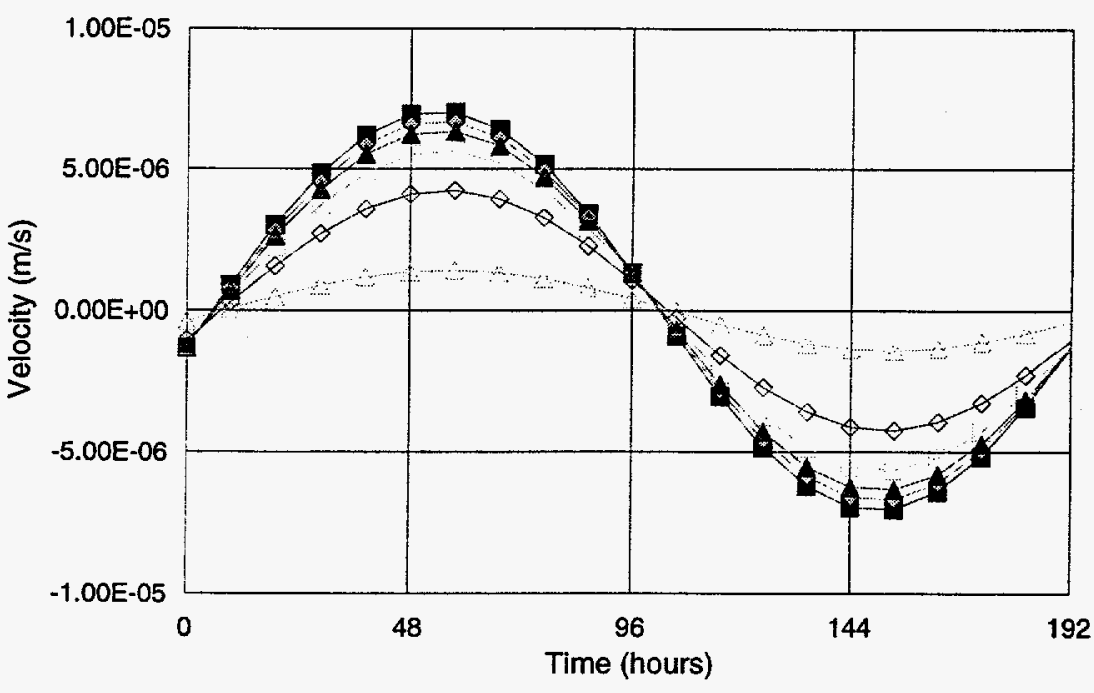

Depth

\begin{tabular}{|c|}
-5 surface \\
5.00 \\
-10.00 \\
20.00 \\
$\approx 40.00$ \\
-80.00 \\
\hline
\end{tabular}

Calculated subsurface pressures and velocities given an imposed sinusoidal surface pressure on a porous medium of some finite thickness.

Medium characteristics:

Permeabilty $=10.0$ darcies

Porosity $=35$ percent

Pore gas characteristics:

Viscosity $=0.0000179 \mathrm{Ns} / \mathrm{m}^{\wedge} 2$

Molecular weight $=29.00 \mathrm{gm} / \mathrm{gm}$ mole
Surface conditions:

Average surface pressure $=100000 \mathrm{~N} / \mathrm{m}^{\wedge} 2$

Peak surface pressure variation from avg $=800 \mathrm{~N} / \mathrm{m}^{\wedge} 2$

Period used $=192$ hours

Depth to impermeable layer $=100.0 \mathrm{~m}$

Figure E2. Pressure and velocity fluctuations with time and depth, based on a pressure amplitude of $16 \mathrm{mbar}\left(1600 \mathrm{~N} / \mathrm{m}^{2}\right)$ over an eight day period. 

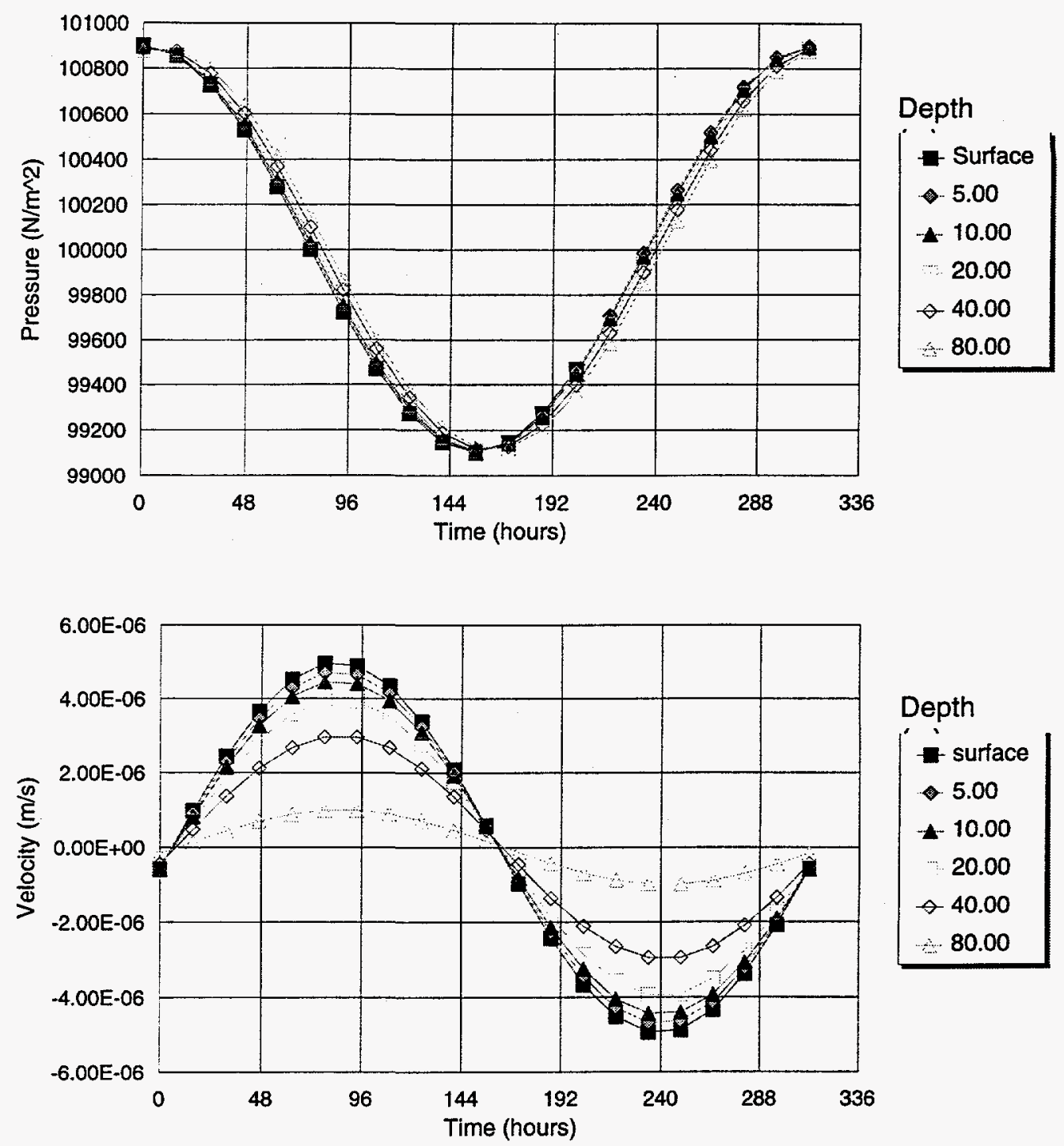

Calculated subsurface pressures and velocities given an imposed sinusoidal surface pressure on a porous medium of some finite thickness.

Medium characteristics:

Permeabilty $=10.0$ darcies

Porosity $=35$ percent

Pore gas characteristics:

Viscosity $=0.0000179 \mathrm{Ns} / \mathrm{m}^{\wedge} 2$

Molecular weight $=29.00 \mathrm{gm} / \mathrm{gm}$ mole
Surface conditions:

Average surface pressure $=100000 \mathrm{~N} / \mathrm{m}^{\wedge} 2$

Peak surface pressure variation from avg $=900 \mathrm{~N} / \mathrm{m}^{\wedge} 2$

Period used $=312$ hours

Depth to impermeable layer $=100.0 \mathrm{~m}$

Figure E3. Pressure and velocity fluctuations with time and depth, based on a pressure amplitude of $18 \mathrm{mbar}\left(1800 \mathrm{~N} / \mathrm{m}^{2}\right)$ over a 13 day period. 
Other factors which effect the calculations include the soil's porosity and permeability, the depth to the impermeable layer, and the mean atmospheric pressure. As permeability increases, the dampening effect of the earth decreases (e.g., pressures at depth follow atmospheric changes more closely), and both the velocity and pressure changes at a given depth increase. A decrease in the soil porosity also results in a decreased dampening effect and increased pressure changes and velocities. Figures E4 and E5 show maximum pressures and velocities calculated for a depth of $10 \mathrm{~m}$ bgs for various permeabilities and porosities. The baseline calculation for the figures had a depth to the impermeable layer of $100 \mathrm{~m}$, a soil permeability of 10 Darcies, a soil porosity of 35 percent, and a mean pressure of 1000 mbars. The pore gas used was air. Figure E6 shows maximum calculated pressures and velocities for this same depth (10 $\mathrm{m}$ bgs) versus the depth to the impermeable layer, L. Unlike permeability and porosity changes, which caused pressure and velocity maximums to follow the same trends, varying the depth to the impermeable layer causes the maximum pressure and velocity to behave opposite of one another. Additionally, an incremental increase in $\mathrm{L}$ does not always cause the pressure and velocity to change in the same way. There is a maximum depth after which no change in either pressure or velocity is seen. Before this depth is reached, there is an optimum depth which maximizes the pore gas velocities. Between the ground surface and this optimum depth, increasing $\mathrm{L}$ causes the pressure change with depth to decrease and the velocity to increase. Changes in the mean atmospheric pressure result in only minimal differences in the calculated pressures and velocities.

While the analytical calculations can be used to estimate soil gas velocities for a defined geometry, the large number of variables makes it difficult to easily determine how variable combinations will impact the results. Figure E7 uses normalized and dimensionless parameters to help predict how a combination of pertinent variables will effect pressure amplitudes at a given depth below the surface. The figure plots the fractional amplitude of the pore pressure oscillation, $\left|\mathrm{q}-\mathrm{P}_{\mathrm{O}}\right| / \Delta \mathrm{P}$, as a function of normalized depth, $\mathrm{x} / \mathrm{L}$ for a range of values for the dimensionless parameter, $\mathrm{kL}$. For example, using a mean pressure of $84,000 \mathrm{~N} / \mathrm{m}^{2}(840 \mathrm{mbar})$, a period of 13 days $\left(1.1232\left(10^{6}\right)\right.$ seconds), and a peak surface pressure variation from the mean atmospheric pressure of $900 \mathrm{~N} / \mathrm{m}^{2}$ ( 9 mbar), a depth to the water table of $150 \mathrm{~m}$, soil permeability of $9.87\left(10^{-12}\right) \mathrm{m}^{2}$ (10 Darcies), soil gas viscosity of $1.79\left(10^{-5}\right) \mathrm{Ns} / \mathrm{m}^{2}$ and a medium porosity of 35 percent. (Values typical for the CWL at Sandia), a value of $\mathrm{kL}=0.69$ is calculated. From Figure E7, a normalized pressure change at a depth 40 feet bgs (normalized depth of 0.6 ) is approximately 0.91 . Thus the estimated peak pressure would be

$$
.91(900)+84000=84,819 \mathrm{~N} / \mathrm{m}^{2} .
$$

Using Equation E2, the exact peak pressure was calculated at $84,840 \mathrm{~N} / \mathrm{m}^{2}$. 


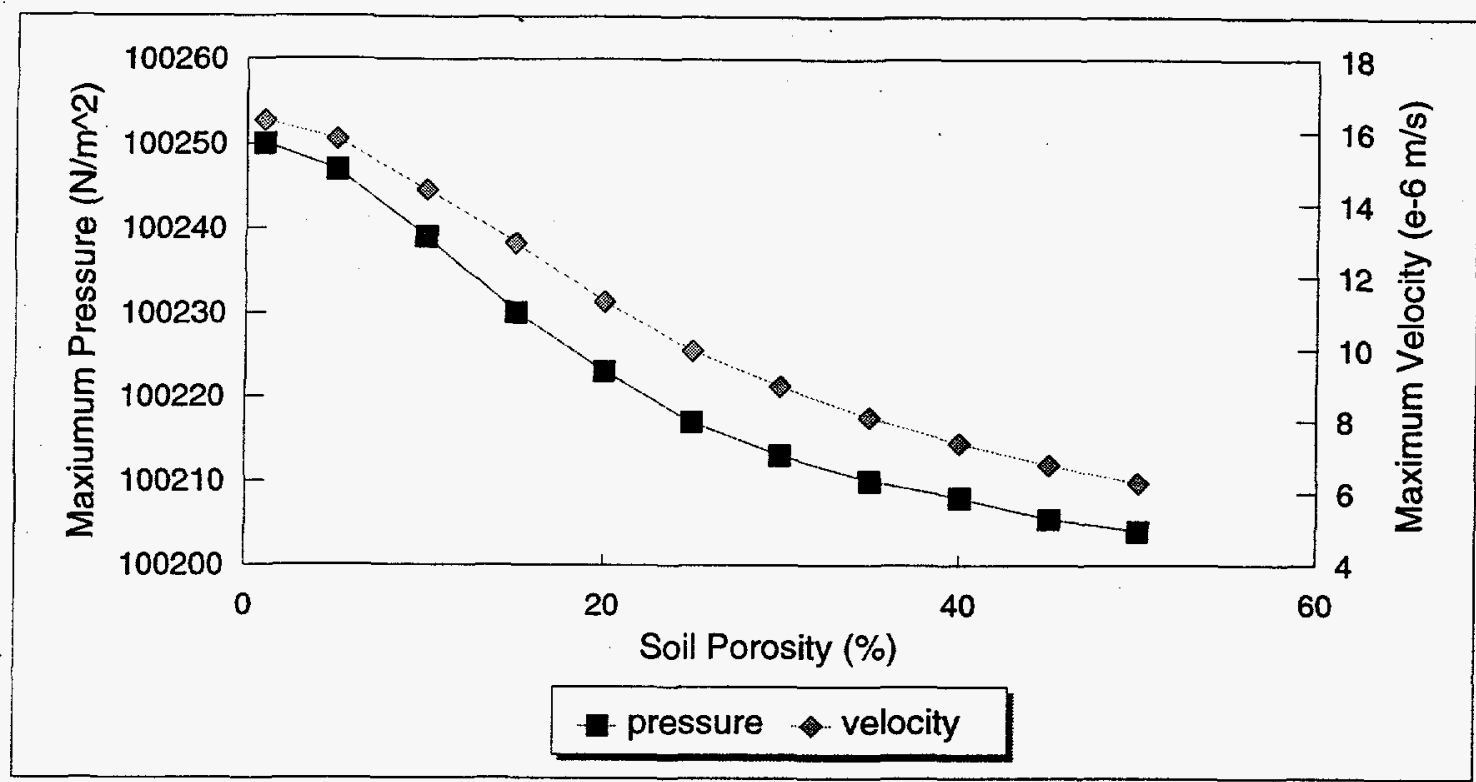

Figure E4. Calculated maximum pressure and velocity of a depth of $10 \mathrm{mbgs}$ versus soil porosity.

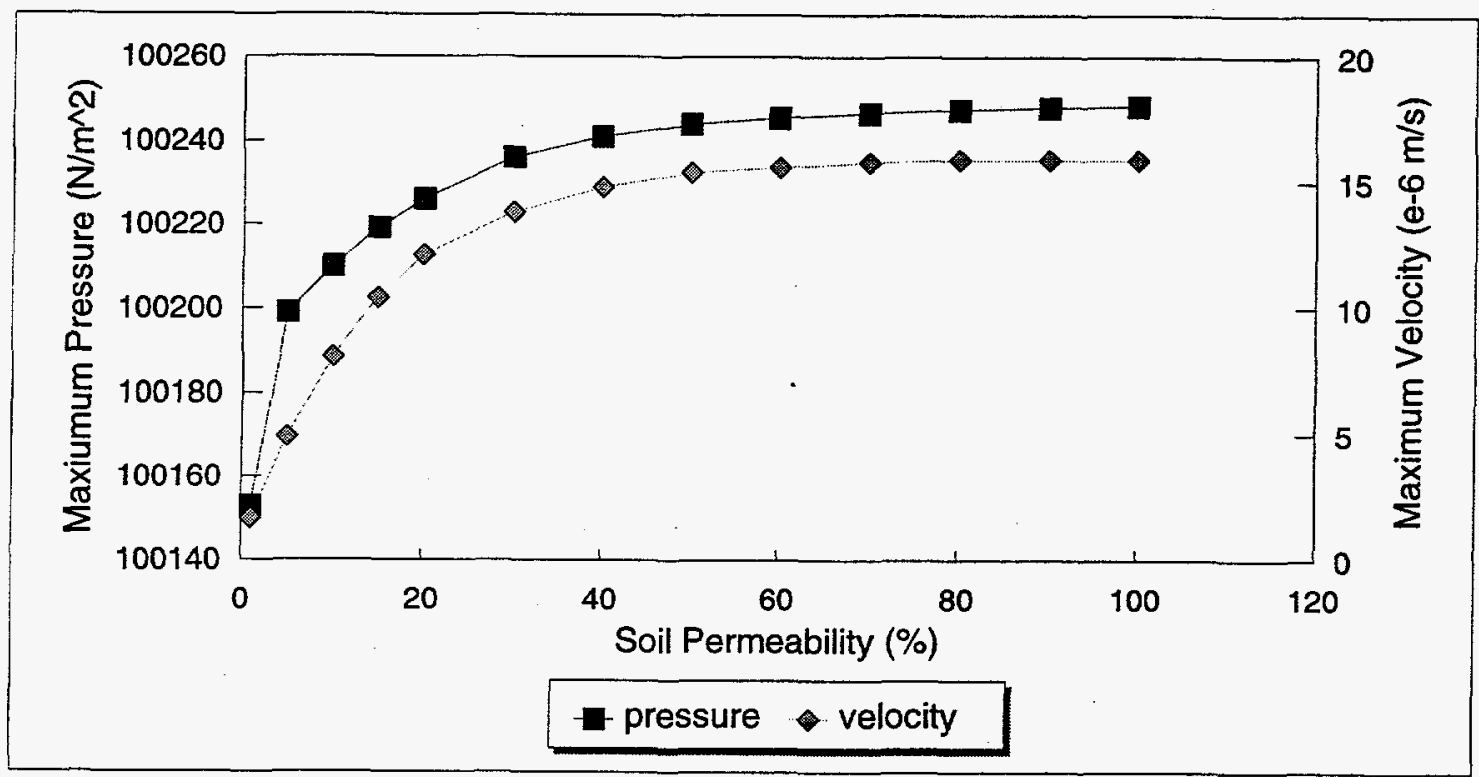

Figure E5. Calculated maximum pressure and velocity at a depth of $10 \mathrm{~m}$ bgs versus soil permeability. 


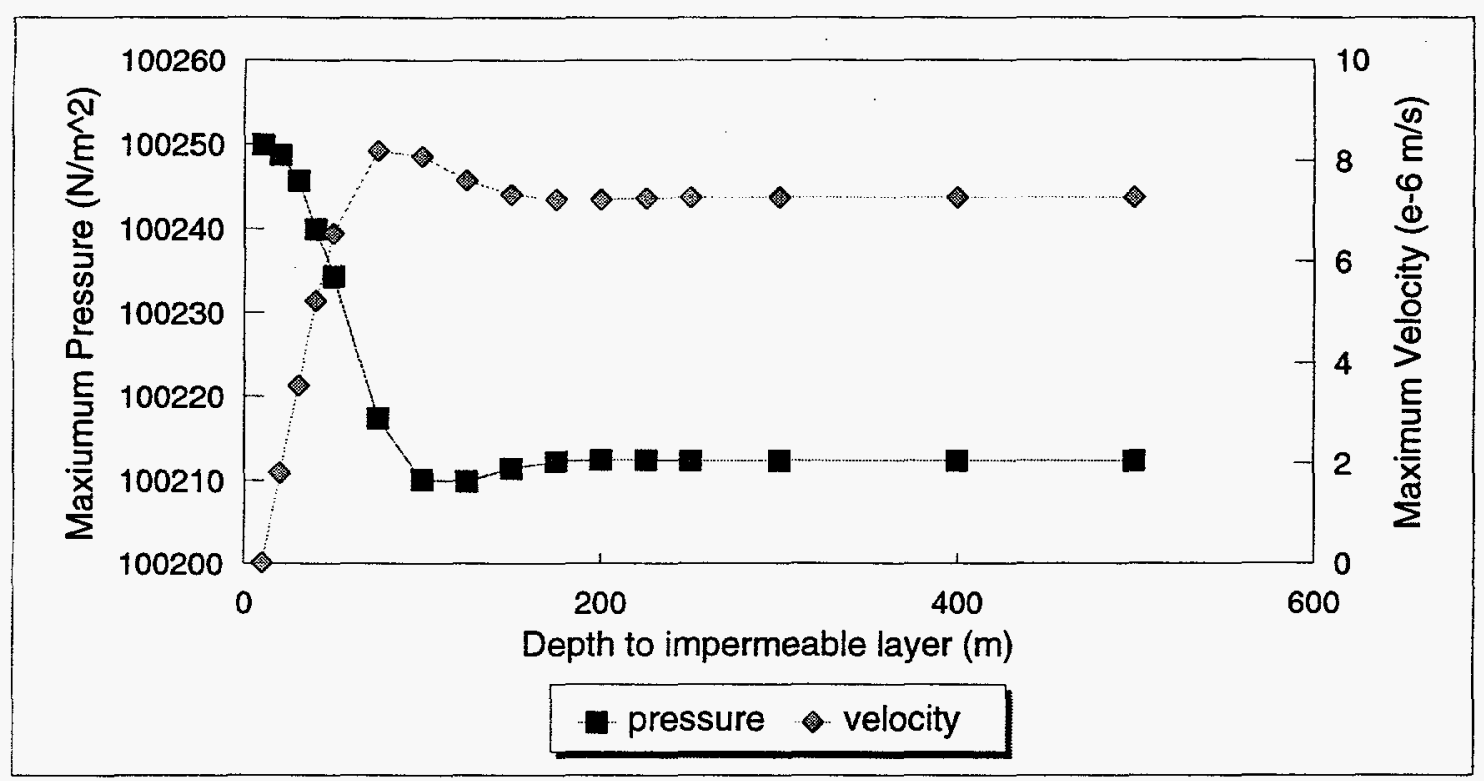

Figure E6. Calculated maximum pressure and velocity at a depth of $10 \mathrm{mbs}$ versus depth to the impermeable layer. 


\section{Relative amplitude of pore pressure ocsillation}

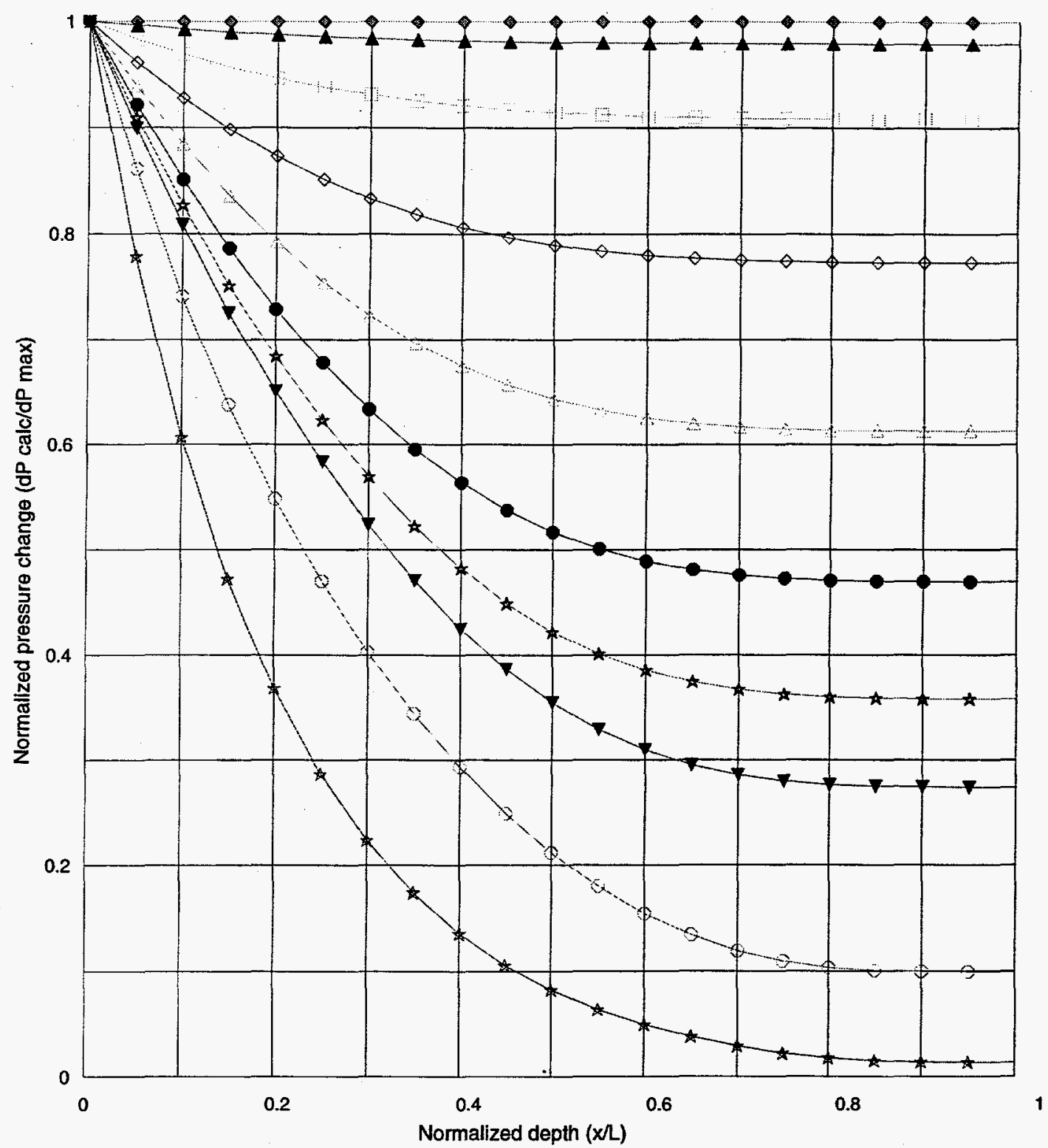

values of $\mathrm{kL}$

$\bullet 0.10 \wedge 0.50 \quad 0.75 \diamond 1.00 \therefore 1.25 \quad 1.50 \star 1.75 \nabla 2.00 \diamond 3.00 \star 5.00$

$\mathrm{dP}$ max $=$ Peak surface pressure variation from average; $k=$ medium constant

$x=d e p$ th bgs pressure calculated for, $L=d e p$ th to impermeable layer

Figure E7. Fractional amplitude of the pore pressure oscillation versus normalized depth. 


\section{APPENDIX F. SUMMARY OF CONTAMINANT CHARACTERISTICS}

Chemical properties of the contaminant to be remediated will affect the design of the barometric pumping system. In particular, the contaminants diffusivity constant in air will influence the plenum and cover seal dimensions, and will be integral to the rate at which the contaminant plume will be ratcheted toward the surface; the vapor pressure will determine the maximum possible concentration of the contaminant in the soil gas; the contaminant's density/molecular weight will determine the extent of gravitational forces on the contaminant plume; the boiling point of the contaminant influences its rate of volatilization and may be important if heating is incorporated in remediation efforts; and health hazards and regulatory release limits in air of the contaminant will determine if there is a need for treatment and/or monitoring of the release vapor. Because of the importance of properties of the contaminants, some effort has been spent to tabulate and analyze available information. This appendix summarizes this information. It is divided into three parts: contaminants typically found at Department of Energy (DOE) sites; priority toxic pollutants as defined by the Environmental Protection Agency (EPA); and a general discussion of contaminant properties.

As a general rule, only contaminants existing as stable liquids or gases were considered. The barometric pumping system is best suited for use in the unsaturated vadose zone, where contaminant movement is due primarily to vapors either diffusing or moving with the soil gas in response to barometric pressure fluctuations. Because sublimation rates of most solids are very low, only liquid or gaseous contaminants were reviewed. It is important to note that contaminants of many sites are not isolated. Many contaminants are mixtures or solutions, and co-disposal of different chemical wastes at the same site (e.g., ground surface, ponds, cribs, basins, pits, piles, injection wells, and landfills) was and is a common practice. These chemical mixtures may have properties very different from their individual compounds.

Physical properties of chemical compounds were taken from numerous references (References F1 through F4). In some instances, reported values or even compound names differed significantly. In cases where there was only one reference value in disagreement from three or more reported values, the value in disagreement was ignored. If no single value was clearly correct, a range of values was given and noted. A range of values was also given and noted in instances where a compound name or formula actually encompassed a group or family of individual compounds.

\section{CONTAMINANTS TYPICALLY FOUND AT DOE SITES}

A draft of the report "Nature of Chemical Contaminants on DOE Lands" (Reference F5) was used as a basis for determining the most common liquid or gaseous waste compounds found in soil throughout the DOE complex. In this report, ninety-one DOE waste sites at eighteen different DOE facilities were researched to 
determine common contaminants in soils. Table F1 lists these compounds. The table is divided into four different categories: chlorinated hydrocarbons; ketones, fuel hydrocarbons, and other. Fuel hydrocarbons, followed by chlorinated hydrocarbons, were the compound classes most commonly reported in sediments by facility. Figure F1 shows the frequency of occurrence of the different compounds at the DOE facilities. The chemicals listed in Table F1 and Figure F1 are not comprehensive. The data came from only 3 percent of the waste sites that exist on DOE lands. Data collected at the DOE sites showed disposal records were often not complete, and at some sites a disparity existed between the chemicals reported to have been disposed of (according to historical records) and those analytically determined to be in the soil and underlying ground water. Most of the compounds discussed above are priority pollutants as listed by the EPA, as most monitoring programs have been directed at environmental compliance. Table F2 lists the non-priority pollutant compounds which were included. These chemical contaminants and others could be much more prevalent than shown, as they have only been analyzed selectively or less frequently. As more data becomes available, it should be expected that this list of compounds will expand.

\section{PRIORITY TOXIC POLLUTANTS}

Based on a consent decree obtained in Federal court by public interest groups, the EPA was directed to establish standards for 65 "priority" toxic pollutants. This list of pollutants and classes of pollutants (Table F3) potentially included thousands of specific pollutants. Finances, materials, and labor needed to test for all of these pollutants would be overwhelming. To help make testing more manageable, EPA chose 129 specific toxic pollutants based on:
1) frequency of occurrence in subsurface
2) chemical stability and structure
3) amount of chemical produced; and
4) availability of chemical standards for measurement

These pollutants are listed in Table F4. Many of these pollutants have already been discussed under typical contaminants at DOE sites (Table F1). These are marked with the notation T1. Many others are solids and need not be reviewed. These are also noted. Table F5 lists those remaining contaminants with their physical properties.

\section{DISCUSSION}

There was not a single reference found which discussed all of the chemicals listed in Tables F1 and F5 in depth. Some of the information, such as the diffusion constant of the compound in air were only found for a few of the chemicals. Other information, such as the vapor pressure, is useful in estimating values necessary for calculations performed throughout this report. This section discusses estimates of constants which were made using the gathered information.

Calculation of diffusion profiles of a compound require that the source vapor or gas concentration of the chemical be known. The transfer of a chemical from a liquid to the vapor or gas phase (volatilization) is governed 
by properties of the chemical and the soil, climatic factors, and the amount of energy available for phase change. Chemical factors include the vapor pressure, boiling point, and solubility of the compound. Soil factors include the soil water content, the bulk density or porosity, and the sorption capacity of the material. Climatic factors are the ambient pressure, temperature, and humidity. Calculation of the vapor/gas concentration with all of these variables is complex. However, an initial maximum concentration can be estimated by using the compound's vapor pressure and the ideal gas law. Table F6 lists calculated maximum concentrations (at STP) for the chemicals listed in Tables F1 and F5. As temperatures of the soil increase toward the chemicals boiling point, the concentration would increase. As soil porosity decreases or the soil sorption capacity increases the concentration would decrease. Lower porosities mean smaller cross-sectional areas for mass transfer, which diminishes the effective gas-liquid mass transfer coefficients, and hence volatilization. Sorption introduces a third phase of the chemical which will decrease the fraction of the contaminant transferring to the gas phase. A high solubility of the chemical in water will also reduce the vapor concentration. Thus at near ambient temperatures, using the vapor pressure to predict the vapor concentration will be a conservative or worst case condition.

The diffusive constant of a chemical through the medium is also necessary to predict diffusion profiles. Graham's Law of Diffusion (Reference F6) shows diffusivities in air are proportional to molecular weights as:

$$
\mathrm{D}_{2}=\mathrm{D}_{1} \sqrt{\frac{\mathrm{MW}}{\mathrm{MW}}}
$$

where $D_{1}$ and $D_{2}$ are the diffusivities of gas 1 and 2 , and $M W_{1}$, and $M W_{2}$ are the molecular weights of the gases. Figure F2 shows calculated diffusivity profiles versus molecular weights. Profiles were calculated using two different gases, hydrogen $\left(\mathrm{H}_{2}\right)$ which has a very low molecular weight ( $\left.2 \mathrm{gm} / \mathrm{gm}-\mathrm{mole}\right)$, and a heavier chemical, trichloroethylene (TCE) whose molecular weight is $131.4 \mathrm{gm} / \mathrm{gm}$ moles. Results using the different gases compare well. Diffusion constants found in the literature are also shown on the figure. These values tend to be equal to or less than those values predicted by Graham's Law.

Because of the soil pore structure, the true diffusion path of the contaminant is greater than the actual distance between any two points. To account for this difference, the diffusion constant in air of a chemical can be multiplied by the tortuosity factor of the medium. The tortuosity factor, $\tau$, is defined as the ratio of the square of the length of the actual flow channel, $\mathrm{L}$, to the length of the porous medium, Le, or

$$
\left(\tau=\left(\frac{\mathrm{L}}{\mathrm{Le}}\right)^{2}\right) .
$$

This factor is always less than one, and is commonly between 0.3 and 0.7 (Reference F7). Thus:

$$
\mathrm{D}_{\text {soilgas }}=\frac{\mathrm{D}_{\text {air }} \bullet \tau}{\varepsilon}
$$


Table F7 lists diffusion constants in air found in the literature for the chemicals listed in Tables F1 and F5.

It also includes effective values calculated using Graham's Law with TCE as the known compound, a typical gas filled porosity of 35 percent, and soil gas tortuosities of $0.3,0.5$, and 0.7 . 
This page intentionally left blank. 
Table F1. Properties of common contaminants at DOE facilities.

\begin{tabular}{|c|c|c|c|c|c|c|c|c|c|c|c|c|}
\hline \multirow[t]{2}{*}{ Chemical } & \multirow[t]{2}{*}{ Synonyms } & \multirow{2}{*}{$\begin{array}{l}\text { b.p. } \\
\left({ }^{\circ} \mathrm{C}\right)\end{array}$} & \multicolumn{3}{|c|}{$\begin{array}{c}\text { Permissible Exposure } \\
\text { limits in Air } \\
\text { (Federal standard) }\end{array}$} & \multirow[t]{2}{*}{ Notes } & \multirow[t]{2}{*}{ Uses } & \multirow[t]{2}{*}{$\begin{array}{l}\text { Molecular } \\
\text { weight }\end{array}$} & \multirow{2}{*}{$\begin{array}{l}\text { Density } \\
\mathrm{g} / \mathrm{ml}\end{array}$} & \multirow[t]{2}{*}{$\begin{array}{l}\text { Solubility } \\
\text { in water }\end{array}$} & \multirow{2}{*}{$\begin{array}{l}\text { Vapor } \\
\text { pressure } \\
\text { (mbar) }\end{array}$} & \multirow{2}{*}{$\begin{array}{l}\text { Diffusivity } \\
\left(\mathrm{cm}^{2} / \mathrm{s}\right)\end{array}$} \\
\hline & & & $\begin{array}{l}\text { TWA } \\
\text { (ppm) }\end{array}$ & $\begin{array}{l}\text { STEL } \\
\text { (ppm) } \\
\end{array}$ & $\begin{array}{l}\text { IDLH } \\
\text { (ppm) } \\
\end{array}$ & & & & & & & \\
\hline \multicolumn{13}{|l|}{ Chlorinated Hydrocarbons } \\
\hline $\begin{array}{l}\text { Trichloroethylene } \\
\mathrm{ClCH}=\mathrm{CCl}_{2}\end{array}$ & $\begin{array}{l}\text { Ethyene trichloride, } \\
\text { Ethinyl trichloride, } \\
\text { Trichloroethene, } \\
\text { Tri, } \\
\text { TCE, }\end{array}$ & $86-87$ & $\begin{array}{c}50 \\
(270 \mathrm{mg} \\
\left./ \mathrm{m}^{3}\right)\end{array}$ & $\begin{array}{c}200 \\
(1080 \mathrm{~m} \\
\left.\mathrm{g} / \mathrm{m}^{3}\right)\end{array}$ & 1,000 & $\begin{array}{l}\text { Numerous states } \\
\text { have set standards } \\
\text { for amount of } \\
\text { chemical permissible } \\
\text { in ambient air. } \\
\text { Exposure to } 8,000 \\
\text { ppm can cause death }\end{array}$ & $\begin{array}{l}\text { Solvent in vapor } \\
\text { degreasing; } \\
\text { extracting caffeine } \\
\text { from coffee; dry- } \\
\text { cleaning agent; } \\
\text { chemical interme- } \\
\text { diate in production of } \\
\text { pesticides, waxes, } \\
\text { gums, resins, tars, } \\
\text { paints, varnishes, etc. }\end{array}$ & 131.39 & 1.46 & $1000 \mu \mathrm{g} / \mathrm{ml}$ & 77.1 & 0.0875 \\
\hline $\begin{array}{l}\text { 1,1,1-Trichloroethane } \\
\mathrm{CH}_{3} \mathrm{CCl}_{3}\end{array}$ & Methyl chloroform & 74 & $\begin{array}{c}350 \\
(1900 \\
\left.\mathrm{mg} / \mathrm{m}^{3}\right)\end{array}$ & & 1,000 & $\begin{array}{l}\text { Numerous states } \\
\text { have set standards } \\
\text { for amount of } \\
\text { chemical permissible } \\
\text { in ambient air. }\end{array}$ & $\begin{array}{l}\text { Degreaser; cleaner of } \\
\text { metals; dry-cleaning } \\
\text { agent; propellant }\end{array}$ & 133.41 & 1.34 & $\begin{array}{l}480 \text { parts per } \\
10^{6} \mathrm{w} / \mathrm{w}\end{array}$ & 133 & 0.0794 \\
\hline $\begin{array}{l}\text { Tetrachloroethylene } \\
\qquad \mathrm{Cl}_{2} \mathrm{C}=\mathrm{CCl}_{2}\end{array}$ & $\begin{array}{l}\text { Perchloroethylene, } \\
\text { Carbon dichloride, } \\
\text { Ethylene tetrachloride, } \\
\text { Perclene, PCE, } \\
\text { Tetrachloroethene }\end{array}$ & 121 & $\begin{array}{c}50^{2} \\
(339 \\
\left.\mathrm{mg} / \mathrm{m}^{3}\right)\end{array}$ & $\begin{array}{c}200^{2} \\
(1368 \\
\left.\mathrm{mg} / \mathrm{m}^{3}\right)\end{array}$ & & $\begin{array}{l}\text { Exposures of } 1000 \\
\text { ppm for } 30 \text { minutes } \\
\text { can cause difficulty } \\
\text { breathing, weakness, } \\
\text { irritability, tremors, } \\
\text { convulsions, } \\
\text { paralysis, coma, } \\
\text { heart irregularities, } \\
\text { and death. }\end{array}$ & $\begin{array}{l}\text { Widely used solvent } \\
\text { (dry-cleaning agent, } \\
\text { de-greaser, chemical } \\
\text { intermediate, } \\
\text { fumigant, and } \\
\text { medically as } \\
\text { anthelmintic. }\end{array}$ & 165.83 & 1.62 & $150 \mu \mathrm{g} / \mathrm{ml}$ & 18.9 & 0.0797 \\
\hline $\begin{array}{l}\text { Dichloromethane } \\
\mathrm{CH}_{2} \mathrm{Cl}_{2}\end{array}$ & $\begin{array}{l}\text { Methylene chloride } \\
\text { Methylene dichloride } \\
\text { Methylene bichloride }\end{array}$ & 40 & $\begin{array}{c}50^{2} \\
(175 \\
\left.\mathrm{mg} / \mathrm{m}^{3}\right) \\
\end{array}$ & & & & & $\cdots$ & 133 & $\begin{array}{c}13.2 \times 10^{6} \\
\mu \mathrm{g} / 1 @ 25^{\circ} \mathrm{C}\end{array}$ & $\begin{array}{l}362.4 \mathrm{~mm} \\
\mathrm{Hg} @ 20^{\circ} \mathrm{C}\end{array}$ & \\
\hline $\begin{array}{c}\text { Chlorobenzene } \\
\mathrm{C}_{6} \mathrm{H}_{5} \mathrm{Cl}\end{array}$ & $\begin{array}{l}\text { Monochlorobenzene; } \\
\text { Chlorobenzol; } \\
\text { Phenyl chloride; } \\
\text { MCB } \\
\end{array}$ & $\begin{array}{r}131- \\
132\end{array}$ & $\begin{array}{c}75 \\
(350 \\
\left.\mathrm{mg} / \mathrm{m}^{3}\right)\end{array}$ & none set & 2,400 & & & 112.6 & 1.11 & & & \\
\hline $\begin{array}{l}\text { 1,1-Dichloroethane } \\
\mathrm{CH}_{3} \mathrm{CHCl}_{2}\end{array}$ & $\begin{array}{l}\text { Asymmetrical } \\
\text { dichlorethane; ethylidene } \\
\text { chloride; } 1,1 \text {-ethylidene } \\
\text { dichloride } \\
\end{array}$ & 57.3 & $\begin{array}{c}100 \\
(400 \\
\left.\mathrm{mg} / \mathrm{m}^{3}\right)\end{array}$ & $\begin{array}{c}250 \\
(1010 \\
\left.\mathrm{mg} / \mathrm{m}^{3}\right)\end{array}$ & 4,000 & & & 99.0 & 1.18 & $5 \mathrm{~g} / \mathrm{l}$ & $\begin{array}{l}230 \mathrm{~mm} \\
\mathrm{Hg} @ 25^{\circ} \mathrm{C}\end{array}$ & \\
\hline $\begin{array}{l}\text { Vinyl Fluoride } \\
\qquad \mathrm{CHF}=\mathrm{CH}_{2}\end{array}$ & $\begin{array}{l}\text { Fluorethylene; } \\
\text { Fluorethene }\end{array}$ & 72 & $\begin{array}{l}\text { No } \\
\text { Federal } \\
\text { stan-- } \\
\text { dards } \\
\end{array}$ & $+\cdots$ & $\bar{\cdots}$ & & $\begin{array}{l}\text { Intermediate to make } \\
\text { polyvinyl fluoride } \\
\text { film }\end{array}$ & 46.05 & & insoluble & 23,960 & -- \\
\hline
\end{tabular}


Table FI. Properties of common contaminants at DOE facilities (Continued).

\begin{tabular}{|c|c|c|c|c|c|c|c|c|c|c|c|c|}
\hline \multirow{2}{*}{ Chemical } & \multirow[t]{2}{*}{ Synonyms } & \multirow{2}{*}{$\begin{array}{l}\text { b.p. } \\
\left({ }^{\circ} \mathrm{C}\right)\end{array}$} & \multicolumn{3}{|c|}{$\begin{array}{c}\text { Permissible Exposure limits } \\
\text { in Air } \\
\text { (Federal standard) }\end{array}$} & \multirow[t]{2}{*}{ Notes } & \multirow[t]{2}{*}{ Uses } & \multirow[t]{2}{*}{$\begin{array}{c}\text { Molecular } \\
\text { weight }\end{array}$} & \multirow{2}{*}{$\begin{array}{c}\text { Density } \\
\mathrm{g} / \mathrm{ml}\end{array}$} & \multirow[t]{2}{*}{$\begin{array}{l}\text { Solubility } \\
\text { in water }\end{array}$} & \multirow{2}{*}{$\begin{array}{c}\text { Vapor } \\
\text { pressure } \\
\text { (mbar) }\end{array}$} & \multirow{2}{*}{$\begin{array}{c}\text { Diffusivity } \\
\left(\mathrm{cm}^{2} / \mathrm{s}\right)\end{array}$} \\
\hline & & & $\begin{array}{l}\text { TWA } \\
(\mathrm{ppm}) \\
\end{array}$ & $\begin{array}{l}\text { STEL } \\
(\mathrm{ppm})\end{array}$ & $\begin{array}{l}\text { IDLH } \\
\text { (ppm) }\end{array}$ & & & & & & & \\
\hline \multicolumn{13}{|c|}{$\begin{array}{l}\text { Chlarinated Hydracarbans } \\
\text { (Cont) }\end{array}$} \\
\hline $\begin{array}{l}\text { 1,1-Dichlorethylene } \\
\mathrm{CCl}_{2}=\mathrm{CH}_{2}\end{array}$ & $\begin{array}{l}\text { Vinylidene chloride; } \\
\text { DCE; VDC }\end{array}$ & 31.7 & $\begin{array}{c}1 \\
(4 \\
\left.\mathrm{mg} / \mathrm{m}^{3}\right)\end{array}$ & $\cdots$ & $\cdots$ & $\begin{array}{l}\text { May damage } \\
\text { developing feus and } \\
\text { cause reproductive } \\
\text { damage in males. } \\
\text { High levels cause a } \\
\text { "drunken" feeling } \\
\text { that can go on to } \\
\text { unconsciousness. }\end{array}$ & $\begin{array}{l}\text { Manufacture of } \\
\text { methyl chloroform }\end{array}$ & 96.94 & 1.22 & $2500 \mu \mathrm{g} / \mathrm{ml}$ & $\begin{array}{l}\quad 667 \\
(591 \mathrm{~mm} \\
\mathrm{Hg})\end{array}$ & 0.0918 \\
\hline $\begin{array}{l}\text { 1,2 Dichloroethylene } \\
\mathrm{ClCH}=\mathrm{CHCl}\end{array}$ & $\begin{array}{l}\text { Acetylene dichloride; } \\
\text { Sym-dichloroethylene }\end{array}$ & $\begin{array}{l}\text { cis- } \\
\text { isomer- } \\
60.3 \\
\text { trans- } \\
\text { issomer } \\
47.5\end{array}$ & $\begin{array}{c}200 \\
(790 \\
\left.\mathrm{mg} / \mathrm{m}^{3}\right)\end{array}$ & $\begin{array}{c}250 \\
(1000 \\
\left.\mathrm{m} / \mathrm{m}^{3}\right)\end{array}$ & 4,000 & & $\begin{array}{l}\text { Solvent for waxes, } \\
\text { resins, and } \\
\text { acetycellulose; used } \\
\text { in the extraction of } \\
\text { rubber, as a } \\
\text { refrigerant, in the } \\
\text { manufacture of } \\
\text { pharmaceuticals and } \\
\text { artificial pearls, in } \\
\text { the extraction of oils } \\
\text { and fats from fish } \\
\text { and meat. }\end{array}$ & 96.94 & 1.28 & $\begin{array}{l}\text { cis-isomer } \\
3500 \mu \mathrm{gg} / \mathrm{ml} \\
\text { trans-isomer } \\
6300 \mu \mathrm{\mu g} / \mathrm{ml}\end{array}$ & \begin{tabular}{l}
\multicolumn{1}{c}{353} \\
cis-isomer \\
$208 \mathrm{~mm}$ \\
$\mathrm{Hg}$ \\
trans- \\
isomer \\
$324 \mathrm{~mm}$ \\
$\mathrm{Hg}$
\end{tabular} & 0.0911 \\
\hline $\begin{array}{l}\text { 2-Chloronaphthalene } \\
\mathrm{C}_{10} \mathrm{H}_{6} \mathrm{Cl}_{2}\end{array}$ & None & & $\ldots$ & $\ldots$ & $\cdots$ & & $\begin{array}{l}\text { Production of } \\
\text { electric condensers; } \\
\text { in insulation of } \\
\text { electric cables and } \\
\text { wires }\end{array}$ & $\ldots$ & 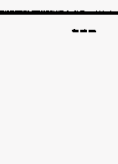 & $\cdots$ & $\overline{N A}$ & $\overline{N A}$ \\
\hline $\begin{array}{l}\text { Carbon Tetrachloride } \\
\mathrm{CCl}_{4}\end{array}$ & $\begin{array}{l}\text { Tetrachloromethane, } \\
\text { Perchloromethane }\end{array}$ & 76.5 & $\begin{array}{c}5 \\
(30 \\
\left.\mathrm{mg} / \mathrm{m}^{3}\right)\end{array}$ & $\begin{array}{c}20 \\
(130 \\
\left.\mathrm{mg} / \mathrm{m}^{3}\right)\end{array}$ & 300 & $\begin{array}{l}\text { Severe exposure can } \\
\text { lead to liver, kidney, } \\
\text { eye, and nerve } \\
\text { damage that may be } \\
\text { delayed after } \\
\text { exposure. Can } \\
\text { cause breathing } \\
\text { stoppage, coma, and } \\
\text { death. }\end{array}$ & \begin{tabular}{|l|} 
Solvent for soils, \\
fats, lacquers, \\
varnishes, nubber, \\
waxes, and resins; \\
drying agent for \\
spark plugs; dry \\
cleaning and fire \\
extinguishing agent; \\
fumigant; \\
anthelmintic agent
\end{tabular} & 153.82 & 1.59 & $800,000 \mu \mathrm{g} / \mathrm{h}$ & $\begin{array}{l}119.4 \\
(55.6 \mathrm{~mm} \\
\mathrm{Hg} @ \\
\left.10^{\circ} \mathrm{C}\right)\end{array}$ & \begin{tabular}{|l|}
0.0828 \\
\end{tabular} \\
\hline
\end{tabular}


Table F1. Properties of common contaminants at DOE facilities (Continued).

\begin{tabular}{|c|c|c|c|c|c|c|c|c|c|c|c|c|}
\hline \multirow[t]{2}{*}{ Chemical } & \multirow[t]{2}{*}{ Synonyms } & \multirow{2}{*}{$\begin{array}{l}\text { b.p. } \\
\left({ }^{\circ} \mathbf{C}\right)\end{array}$} & \multicolumn{3}{|c|}{$\begin{array}{c}\text { Permissible Exposure limits } \\
\text { in Air } \\
\text { (Federal standard) }\end{array}$} & \multirow[t]{2}{*}{ Notes } & \multirow[t]{2}{*}{ Uses } & \multirow[t]{2}{*}{$\begin{array}{l}\text { Molecular } \\
\text { weight }\end{array}$} & \multirow{2}{*}{$\begin{array}{c}\text { Density } \\
\mathrm{g} / \mathrm{ml}\end{array}$} & \multirow[t]{2}{*}{$\begin{array}{l}\text { Solubility } \\
\text { in water }\end{array}$} & \multirow{2}{*}{$\begin{array}{c}\text { Vapor } \\
\text { pressure } \\
\text { (mbar) }\end{array}$} & \multirow{2}{*}{$\begin{array}{c}\text { Diffusivit }] \\
\left(\mathrm{cm}^{2} / \mathrm{s}\right)\end{array}$} \\
\hline & & & $\begin{array}{l}\text { TWA } \\
(\mathrm{ppm})\end{array}$ & $\begin{array}{l}\text { STEL } \\
\text { (ppm) }\end{array}$ & $\begin{array}{l}\text { IDLH } \\
\text { (ppm) }\end{array}$ & & & & & & & \\
\hline \multicolumn{13}{|l|}{$\begin{array}{l}\text { Chlorinated Hydrocarbons } \\
\text { (Cont) }\end{array}$} \\
\hline $\begin{array}{r}\text { Chloroform } \\
\mathrm{CHCl}_{3}\end{array}$ & $\begin{array}{l}\text { Trichloromethane } \\
\text { Methane trichloride }\end{array}$ & 61.7 & $\begin{array}{c}2 \\
(10 \\
\left.\mathrm{mg} / \mathrm{m}^{3}\right)\end{array}$ & $\begin{array}{c}(225 \\
\mathrm{mg} / \mathrm{m} 3)\end{array}$ & 1,000 & $\begin{array}{l}\text { Chloroform is } \\
\text { widely distributed in } \\
\text { the atmosphere and } \\
\text { water primarily as a } \\
\text { consequence of } \\
\text { chlorination. } \\
\text { Classified as mod- } \\
\text { erately toxic. }\end{array}$ & \begin{tabular}{|l|} 
Solvent; extraction \\
and purification of \\
penicillin and other \\
pharmaceuticals; \\
manufacture of silk, \\
plastics, floor \\
polishes and \\
fluorocarbons.
\end{tabular} & 119.38 & 1.48 & $\begin{array}{c}7.42 \times 10^{6} \mu g / l \\
@ 25^{\circ} \mathrm{C}\end{array}$ & $\begin{array}{l}\quad 213 \\
(200 \mathrm{~mm} \\
\mathrm{Hg} \mathrm{@} \\
\left.25^{\circ} \mathrm{C}\right)\end{array}$ & 0.0888 \\
\hline $\begin{array}{l}\text { Freon-12 } \\
\quad \mathrm{Cl}_{2} \mathrm{CF}_{2} \\
\end{array}$ & $\begin{array}{l}\text { Methane-dichlorodi- } \\
\text { Fluoro- }\end{array}$ & -29.8 & $\cdots$ & $-\cdots$ & $\cdots$ & & & 120.91 & 1.32 & soluble & 5.669 & 0.0958 \\
\hline $\begin{array}{l}\text { 1,1-Dichloroethane } \\
\mathrm{CH}_{3} \mathrm{CHCl}_{2}\end{array}$ & $\begin{array}{l}\text { Asymmetrical } \\
\text { dichloroethane; } \\
\text { Ethylidene chloride; } \\
\text { 1,1-ethylidene dichloride }\end{array}$ & 57.3 & $\begin{array}{c}100 \\
(400 \\
\left.\mathrm{mg} / \mathrm{m}^{3}\right)\end{array}$ & $\begin{array}{c}250 \\
(1010 \\
\left.\mathrm{m} / \mathrm{m}^{3}\right)\end{array}$ & 4,000 & $\begin{array}{l}\text { May damage } \\
\text { developing ferus; } \\
\text { exposure can cause } \\
\text { drowsiness, } \\
\text { unconsciousness, } \\
\text { and death. }\end{array}$ & $\begin{array}{l}\text { Solvent and cleaning } \\
\text { and degreasing } \\
\text { agent: intermediate } \\
\text { in organic synthesis. }\end{array}$ & 98.96 & 1.18 & $5 \mathrm{~g} /$ & $\begin{array}{l}242.7 \\
(230 \mathrm{~mm} \\
\mathrm{Hg} @ \\
\left.25^{\circ} \mathrm{C}\right)\end{array}$ & 0.0919 \\
\hline $\begin{array}{l}\text { 1,2-Dichloroethane } \\
\mathrm{CH}_{2} \mathrm{CL}-\mathrm{CH}_{2} \mathrm{CL}\end{array}$ & & 82.9 & 10 & -- & -- & & & 98.96 & 1.25 & $8.1 \mathrm{~g} /$ & $\begin{array}{c}85.9 \\
(85 \mathrm{~mm} \mathrm{Hg} \\
\left(25^{\circ} \mathrm{C}\right)\end{array}$ & \begin{tabular}{|l|}
0.0907 \\
\end{tabular} \\
\hline $\begin{array}{l}\text { 1,1,2,2-Tetrachloroethane } \\
\mathrm{CHCl}_{2} \mathrm{CHCl}_{2}\end{array}$ & $\begin{array}{l}\text { Sym-tetrachloroethane; } \\
\text { acetylene tertachloride, } \\
\text { ethane tetrachloride }\end{array}$ & 146 & $\begin{array}{c}1 \\
(7 \\
\left.\mathrm{mg} / \mathrm{m}^{3}\right)\end{array}$ & & 150 & $\begin{array}{l}\text { Large accidental } \\
\text { exposures have } \\
\text { resulted in death. }\end{array}$ & $\begin{array}{l}\text { Dry cleaning agent; } \\
\text { fumigants in cement } \\
\text { and lacquers; used in } \\
\text { manufacture of } \\
\text { tetrachloroethylene, } \\
\text { artificial silk, artifi- } \\
\text { cial leather, and } \\
\text { artificial pearls. }\end{array}$ & 167.85 & 1.60 & slightly soluble & 6.47 & 0.0722 \\
\hline \multicolumn{13}{|l|}{ Ketones } \\
\hline $\begin{array}{l}\text { Acetone } \\
\quad \mathrm{CH}_{3} \mathrm{COCH}_{3}\end{array}$ & $\begin{array}{l}\text { Dimethyl ketone; } \\
\text { b-ketopropane; } \\
\text { 2-propanone; } \\
\text { pyroacetic ether }\end{array}$ & 56.5 & $\begin{array}{l}1,000 \\
(2400 \\
\left.\mathrm{mg} / \mathrm{m}^{3}\right)\end{array}$ & & 20,000 & $\begin{array}{l}\text { Irritation of eyes, } \\
\text { nose, and throat, } \\
\text { headaches, } \\
\text { dizziness, and } \\
\text { dermatitis }\end{array}$ & $\begin{array}{l}\text { Solvent used in } \\
\text { production of } \\
\text { lubricating oils and } \\
\text { as an intermediate in } \\
\text { the manufacture of } \\
\text { chloroform and } \\
\text { various pharma- } \\
\text { ceuticals and } \\
\text { pesticides. }\end{array}$ & 58.08 & 0.79 & $\begin{array}{l}\text { soluble in all } \\
\text { proportions }\end{array}$ & 247 & 0.1049 \\
\hline
\end{tabular}


Table F1. Properties of common contaminants at DOE facilities (Continued).

\begin{tabular}{|c|c|c|c|c|c|c|c|c|c|c|c|c|}
\hline \multirow[t]{2}{*}{ Chemical } & \multirow[t]{2}{*}{ Synonyms } & \multirow{2}{*}{$\begin{array}{l}\text { b.p. } \\
\left({ }^{\circ} \mathrm{C}\right)\end{array}$} & \multicolumn{3}{|c|}{$\begin{array}{c}\text { Permissible Exposure limits } \\
\text { in Air } \\
\text { (Federal standard) }\end{array}$} & \multirow[t]{2}{*}{ Notes } & \multirow[t]{2}{*}{ Uses } & \multirow[t]{2}{*}{$\begin{array}{l}\text { Molecular } \\
\text { weight }\end{array}$} & \multirow{2}{*}{$\begin{array}{c}\text { Density } \\
\mathrm{g} / \mathrm{ml}\end{array}$} & \multirow[t]{2}{*}{$\begin{array}{l}\text { Solubility } \\
\text { in water }\end{array}$} & \multirow{2}{*}{$\begin{array}{c}\text { Vapor } \\
\text { pressure } \\
\text { (mbar) }\end{array}$} & \multirow{2}{*}{$\begin{array}{c}\text { Diffusivity } \\
\left(\mathrm{cm}^{2} / \mathrm{s}\right)\end{array}$} \\
\hline & & & $\begin{array}{l}\text { TWA } \\
\text { (ppm) }\end{array}$ & $\begin{array}{l}\text { STEL } \\
\text { (ppm) }\end{array}$ & $\begin{array}{l}\text { IDLH } \\
\text { (ppm) } \\
\end{array}$ & & & & & & & \\
\hline \multicolumn{13}{|l|}{ Ketones (Cont). } \\
\hline $\begin{array}{l}\text { Methyl Ethyl Ketone } \\
\qquad \mathrm{CH}_{3} \mathrm{COCH}_{2} \mathrm{CH}_{3}\end{array}$ & $\begin{array}{l}\text { MEK; 2-butanone; } \\
\text { butanone; ethyl methyl } \\
\text { ketone }\end{array}$ & $79-80$ & $\begin{array}{c}200 \\
(590 \\
\left.\mathrm{mg} / \mathrm{m}^{3}\right)\end{array}$ & $\begin{array}{c}300 \\
(885 \\
\left.\mathrm{mg} / \mathrm{m}^{3}\right)\end{array}$ & 3,000 & $\begin{array}{l}\text { Inhalation of } 300 \text { to } \\
600 \text { ppm have } \\
\text { caused numbness in } \\
\text { fingers, arms, and } \\
\text { legs accompanied } \\
\text { by headache, } \\
\text { nausea, vomiting, } \\
\text { and fainting. }\end{array}$ & $\begin{array}{l}\text { Solvent in } \\
\text { nitrocellulose coating } \\
\text { and vinyl film } \\
\text { manufacture, in } \\
\text { cements and } \\
\text { adhesives, and in the } \\
\text { dewaxing of } \\
\text { lubricating oil; an } \\
\text { intermediate in drug } \\
\text { manufacture }\end{array}$ & 72.12 & 0.81 & Very soluble & 105 & $\cdots$ \\
\hline $\begin{array}{l}\text { Methyl Isobutyl Ketone } \\
\qquad \mathrm{CH}_{3} \mathrm{COCH}_{2} \mathrm{CH}\left(\mathrm{CH}_{3}\right)_{2}\end{array}$ & $\begin{array}{l}\text { 4-Methyl--2-pentanone; } \\
\text { isobutyl methyl ketone; } \\
\text { MIB K; hexone }\end{array}$ & $\begin{array}{l}117- \\
118\end{array}$ & $\begin{array}{c}50 \\
(205 \\
\left.\mathrm{mg} / \mathrm{m}^{3}\right)\end{array}$ & $\begin{array}{c}75 \\
(300 \\
\left.\mathrm{mg} / \mathrm{m}^{3}\right)\end{array}$ & & $\begin{array}{l}\text { Inhalation may } \\
\text { cause loss of } \\
\text { appetite, nausea, } \\
\text { vomiting, and } \\
\text { diarrhea. }\end{array}$ & $\begin{array}{l}\text { Solvent in paints, } \\
\text { varnishes, and } \\
\text { lacquers; an alcohol } \\
\text { denaturant and as a } \\
\text { solvent in uranium } \\
\text { extraction from } \\
\text { fission products. }\end{array}$ & 100.16 & 0.80 & slightly soluble & 20.2 & 0.0702 \\
\hline \multicolumn{13}{|l|}{ Fuel Hydrocarhons } \\
\hline $\begin{array}{l}\text { Toluene } \\
\qquad \mathrm{C}_{6} \mathrm{H}_{5} \mathrm{CH}_{3}\end{array}$ & $\begin{array}{l}\text { Toluol; } \\
\text { Methylbenzene; } \\
\text { Phenylmethane; } \\
\text { Menthylbenzol }\end{array}$ & $\begin{array}{l}110- \\
111\end{array}$ & $\begin{array}{c}100 \\
(375 \\
\left.\mathrm{mg} / \mathrm{m}^{3}\right)\end{array}$ & $\begin{array}{c}150 \\
(560 \\
\left.\mathrm{mg} / \mathrm{m}^{3}\right)\end{array}$ & 2,000 & $\begin{array}{l}2-500 \text { ppm can } \\
\text { cause heidaches, } \\
\text { nausea, loss of } \\
\text { appetite, loss of } \\
\text { energy, loss of } \\
\text { coordination, and } \\
\text { coma. }\end{array}$ & $\begin{array}{l}\text { Manufacture of } \\
\text { benzene; chemical } \\
\text { feed for numerous } \\
\text { compounds; solvent } \\
\text { for paints and } \\
\text { coatings; component } \\
\text { of auto and aviation } \\
\text { fuels. }\end{array}$ & 92.15 & 0.87 & $534 \mathrm{mg} /$ & $\begin{array}{r}27.8 \\
(30 \mathrm{~mm} \mathrm{Hg} \\
\left.@ 26^{\circ} \mathrm{C}\right)\end{array}$ & 0.0763 \\
\hline $\begin{array}{l}\text { Xylenes } \\
\qquad \mathrm{C}_{6} \mathrm{H}_{4}\left(\mathrm{CH}_{3}\right)_{2}\end{array}$ & $\begin{array}{l}\text { Xylol; } \\
\text { dimethylbenzene }\end{array}$ & $\begin{array}{l}138- \\
144\end{array}$ & $\begin{array}{c}100 \\
(435 \\
\left.\mathrm{mg} / \mathrm{m}^{3}\right)\end{array}$ & $\begin{array}{c}150 \\
(655 \\
\left.\mathrm{mg} / \mathrm{m}^{3}\right)\end{array}$ & 10,000 & $\begin{array}{l}\text { Exists in three } \\
\text { isomeric forms; } \\
\text { Exposure to vapor } \\
\text { can irritate nose and } \\
\text { throat; levels of } 230 \\
\text { ppm for } 15 \text { minutes } \\
\text { may cause light- } \\
\text { headedness without } \\
\text { loss of equilibrium. }\end{array}$ & $\begin{array}{l}\text { Solvent; constituent } \\
\text { of paint, lacquers, } \\
\text { varnishes, inks, } \\
\text { dyes, adhesives, } \\
\text { cements, cleaning } \\
\text { fluids, and aviation } \\
\text { fuels; used as a } \\
\text { chemical feed stock } \\
\text { for various } \\
\text { compounds; used in } \\
\text { the manufacture of } \\
\text { perfumes, insect } \\
\text { repellents, epoxy } \\
\text { resins, pharmaceu- } \\
\text { ticals, and in the } \\
\text { leather industry. }\end{array}$ & 106.17 & $\begin{array}{l}0.86- \\
0.88\end{array}$ & slightly soluble & 1 & -- \\
\hline
\end{tabular}


Table F1. Properties of common contaminants at DOE facilities (Continued).

\begin{tabular}{|c|c|c|c|c|c|c|c|c|c|c|c|c|}
\hline \multirow[t]{2}{*}{ Chemical } & \multirow[t]{2}{*}{ Synonyms } & \multirow{2}{*}{$\begin{array}{l}\text { b.p. } \\
\left({ }^{\circ} \mathrm{C}\right)\end{array}$} & \multicolumn{3}{|c|}{$\begin{array}{c}\text { Permissible Exposure limits } \\
\text { in Air } \\
\text { (Federal standard) }\end{array}$} & \multirow[t]{2}{*}{ Notes } & \multirow[t]{2}{*}{ Uses } & \multirow[t]{2}{*}{$\begin{array}{c}\text { Molecular } \\
\text { weight }\end{array}$} & \multirow{2}{*}{$\begin{array}{c}\text { Density } \\
\mathrm{g} / \mathrm{ml}\end{array}$} & \multirow[t]{2}{*}{$\begin{array}{l}\text { Solubility } \\
\text { in water }\end{array}$} & \multirow{2}{*}{$\begin{array}{c}\text { Vapor } \\
\text { pressure } \\
\text { (mbar) }\end{array}$} & \multirow{2}{*}{$\begin{array}{l}\text { Diffusivity } \\
\left(\mathrm{cm}^{2} / \mathrm{s}\right)\end{array}$} \\
\hline & & & $\begin{array}{l}\text { TWA } \\
(\mathrm{ppm})\end{array}$ & $\begin{array}{l}\text { STEL } \\
(\mathrm{ppm})\end{array}$ & $\begin{array}{l}\text { IDLH } \\
\text { (ppm) } \\
\end{array}$ & & & & & & & \\
\hline \multicolumn{13}{|l|}{ Fuel Hydrocarbons (Cont). } \\
\hline $\begin{array}{l}\text { Ethylbenzene } \\
\qquad \mathrm{C}_{6} \mathrm{H}_{5} \mathrm{CH}_{2} \mathrm{CH}_{3}\end{array}$ & $\begin{array}{l}\text { Phenylethane; } \\
\text { EB }\end{array}$ & 136 & $\begin{array}{c}100 \\
(435 \\
\left.\mathrm{m} / \mathrm{m}^{3}\right)\end{array}$ & $\begin{array}{c}125 \\
(545 \\
\left.\mathrm{mg}^{3} \mathrm{~m}^{3}\right)\end{array}$ & 2,000 & $\begin{array}{l}200 \text { ppm can cause } \\
\text { iritation; kidney, liver, } \\
\text { chronic respiratory, } \\
\text { and skin disease. }\end{array}$ & $\begin{array}{l}\text { Manufacture of } \\
\text { cellulose acetate, } \\
\text { styrene and syn- } \\
\text { thetic rubber; } \\
\text { solvent; } \\
\text { component of } \\
\text { automotive and } \\
\text { aviation gasoline. }\end{array}$ & 106.17 & 0.87 & $866 \mathrm{mg} / \mathrm{l}$ & 9.3 & 0.0693 \\
\hline $\begin{array}{l}\text { Benzene } \\
\quad \mathrm{C}_{6} \mathrm{H}_{6}\end{array}$ & $\begin{array}{l}\text { Benzol, phenyl hydride; } \\
\text { coal naphtha; phene; } \\
\text { benxole; cyclohexarriene }\end{array}$ & 80 & $\begin{array}{c}10 \\
(30 \\
\left.\mathrm{mg} / \mathrm{m}^{3}\right)\end{array}$ & & 2,000 & $\begin{array}{l}\text { Inhalation may } \\
\text { produce both nerve } \\
\text { and blood effects; } \\
\text { death has occurred at } \\
20,000 \text { ppm for } 5-10 \\
\text { minutes, or } 7.500 \mathrm{ppm} \\
\text { for } 30 \text { minutes. }\end{array}$ & $\begin{array}{l}\text { Constituent in } \\
\text { motor fuels; } \\
\text { solvent for fats, } \\
\text { inks, oils, paints, } \\
\text { plastics, and } \\
\text { rubber; } \\
\text { manufacture of } \\
\text { detergents, } \\
\text { explosives, } \\
\text { pharmaceuticals, } \\
\text { and dye-sufffs } \\
\end{array}$ & $\overline{78.12}$ & 0.88 & decomposes & 99.7 & 0.0859 \\
\hline $\begin{array}{l}\mathrm{N} \text {-Hexane } \\
\quad \mathrm{CH}_{3}\left(\mathrm{CH}_{2}\right)_{4} \mathrm{CH}_{3}\end{array}$ & & 69 & $\begin{array}{c}50 \\
(180 \\
\left.\mathrm{mg} / \mathrm{m}^{3}\right)\end{array}$ & & 5,000 & $\begin{array}{l}\text { Inhalation of levels } \\
>500 \text { ppm may cause } \\
\text { headaches, abdominal } \\
\text { cramps, uburing } \\
\text { feeling of the face, and } \\
\text { numberss and } \\
\text { weakness of the fin- } \\
\text { gers and toes. Levels } \\
>1300 \text { ppm may cause } \\
\text { nausea and irititation of } \\
\text { the nose and throat. }\end{array}$ & $\begin{array}{l}\text { Solvent, } \\
\text { particularly in the } \\
\text { extraction of } \\
\text { edible fats and } \\
\text { oils; laborataory } \\
\text { reagent; iquid in } \\
\text { low temperature } \\
\text { thermometers }\end{array}$ & 86.18 & 0.66 & insoluble & 160 & 0.0732 \\
\hline $\begin{array}{c}\text { Cyclohexane } \\
\mathrm{C}_{6} \mathrm{H}_{12}\end{array}$ & $\begin{array}{l}\text { Hexahydrobenzene; } \\
\text { Hexamethylene; } \\
\text { Benzene Hexahydride; } \\
\text { Hexanaphthene }\end{array}$ & $80-81$ & $\begin{array}{c}300 \\
(1050 \\
\left.\mathrm{mg} / \mathrm{m}^{3}\right)\end{array}$ & $\begin{array}{c}375 \\
(1300 \\
\left.\mathrm{mg} / \mathrm{m}^{3}\right)\end{array}$ & 10,000 & $\begin{array}{l}\text { Inhalation of levels } \\
>300 \text { ppm may cause } \\
\text { irritation of eyes, nose, } \\
\text { and throat; levels of } \\
1800 \text { ppm can cause } \\
\text { death }\end{array}$ & $\begin{array}{l}\text { Chemical } \\
\text { intermediate; } \\
\text { solvent for fats, } \\
\text { oils, waxes, } \\
\text { resins, and some } \\
\text { synthetic rubbers; } \\
\text { extractant of } \\
\text { essential oils in } \\
\text { the perfume } \\
\text { industry } \\
\end{array}$ & 84.16 & 0.92 & insoluble & 103 & 0.0744 \\
\hline
\end{tabular}


Table F1. Properties of common contaminants at DOE facilities (Continued).

\begin{tabular}{|c|c|c|c|c|c|c|c|c|c|c|c|c|}
\hline \multirow[t]{2}{*}{ Chemical } & \multirow[t]{2}{*}{ Synonyms } & \multirow{2}{*}{$\begin{array}{l}\text { b.p. } \\
\left({ }^{\circ} \mathrm{C}\right)\end{array}$} & \multicolumn{3}{|c|}{$\begin{array}{c}\text { Permissible Exposure limits } \\
\text { in Air } \\
\text { (Federal standard) }\end{array}$} & \multirow[t]{2}{*}{ Notes } & \multirow[t]{2}{*}{ Uses } & \multirow[t]{2}{*}{$\begin{array}{c}\text { Molecular } \\
\text { weight }\end{array}$} & \multirow{2}{*}{$\begin{array}{c}\text { Density } \\
\mathbf{g} / \mathbf{m l}\end{array}$} & \multirow[t]{2}{*}{$\begin{array}{l}\text { Solubility } \\
\text { in water }\end{array}$} & \multirow{2}{*}{$\begin{array}{l}\text { Vapor } \\
\text { pressure } \\
\text { (mbar) }\end{array}$} & \multirow{2}{*}{$\begin{array}{l}\text { Diffusivity } \\
\left(\mathrm{cm}^{2} / \mathrm{s}\right)\end{array}$} \\
\hline & & & \begin{tabular}{l|} 
TWA \\
$(\mathrm{ppm})$
\end{tabular} & $\begin{array}{l}\text { STEL } \\
\text { (ppm) }\end{array}$ & $\begin{array}{l}\text { IDLH } \\
(\mathrm{ppm})\end{array}$ & & & & & & & \\
\hline \multicolumn{13}{|l|}{ Phthalates } \\
\hline $\begin{array}{l}\text { Butyl Benzyl Phthalate } \\
{ }_{\mathrm{H} 5)} \mathrm{C}_{6} \mathrm{H}_{4}\left(\mathrm{OCOC}_{4} \mathrm{H}_{9}\right)\left(\mathrm{OCOCH}_{2} \mathrm{C}_{6}\right.\end{array}$ & & 370 & $\begin{array}{c}5 \\
\mathrm{mg} / \mathrm{m}^{3}\end{array}$ & & & Slightly toxic & $\begin{array}{l}\text { Plasticizer for } \\
\text { polyvinyl and } \\
\text { cellulosic resins; an } \\
\text { organic intermediate. } \\
\end{array}$ & & & & & \\
\hline $\begin{array}{l}\text { Diethyl Phthalate } \\
\qquad \mathrm{C}_{6} \mathrm{H}_{4}\left(\mathrm{OCOC}_{2} \mathrm{H}_{5}\right)_{2}\end{array}$ & DEP & 296 & $\begin{array}{c}5 \\
\mathrm{mg} / \mathrm{m}^{3}\end{array}$ & $10 \mathrm{mg} / \mathrm{m}^{3}$ & & $\begin{array}{l}\text { Inhalation of levels } \\
>500 \mathrm{mg} / \mathrm{m}^{3} \text { may } \\
\text { cause inratation (short } \\
\text { term exposure). }\end{array}$ & $\begin{array}{l}\text { Solvent in cellulose } \\
\text { esters; vehicle in } \\
\text { pesticidal sprays, } \\
\text { fixative and solvent } \\
\text { in perfumery; plasti- } \\
\text { cizer in solid rocket } \\
\text { propellants. }\end{array}$ & 222.2 & 1.12 & insoluble & & \\
\hline \multicolumn{13}{|l|}{ Qthers } \\
\hline $\begin{array}{l}\text { Chlordane } \\
\qquad \mathrm{C}_{10} \mathrm{H}_{6} \mathrm{Cl}_{8}\end{array}$ & $\begin{array}{l}\text { ENT 9932; } \\
\text { Octachlor@ }\end{array}$ & 175 & $\begin{array}{c}0.5 \\
\mathrm{mg} / \mathrm{m}^{3}\end{array}$ & $2.0 \mathrm{mg} / \mathrm{m}^{3}$ & $\begin{array}{l}500 \\
\mathrm{mg} / \mathrm{m}^{3}\end{array}$ & $\begin{array}{l}\text { Increases sensitivity } \\
\text { to stimuli, tumors, } \\
\text { muscular in } \\
\text { coordination, and } \\
\text { convulsions with or } \\
\text { without coma. }\end{array}$ & $\begin{array}{l}\text { Termite control, } \\
\text { insecticide for homes } \\
\text { and gardens; control } \\
\text { for soil insects } \\
\text { during production of } \\
\text { crops such as corn. }\end{array}$ & 409.78 & 1.61 & $\begin{array}{c}9 \mu \mathrm{g} / 1 \\
20-25^{\circ} \mathrm{C}\end{array}$ & $1.3\left(10^{-6}\right)$ & \\
\hline $\begin{array}{l}\text { Polychlorinated } \\
\text { Biphenyls (PCB's) } \\
\mathrm{C}_{12} \mathrm{H}_{10-\mathrm{x}} \mathrm{Cl}_{x}\end{array}$ & $\begin{array}{l}\text { PCB's; } \\
\text { chlorodiphenyls; } \\
\text { Araclors@; } \\
\text { Kanechlors@ }\end{array}$ & $\begin{array}{r}325- \\
366\end{array}$ & $\begin{array}{l}0.5-1 \\
\mathrm{mg} / \mathrm{m}^{3}\end{array}$ & $1-2 \mathrm{mg} / \mathrm{m}^{3}$ & $\begin{array}{l}5-10 \\
\mathrm{~m} / \mathrm{m}^{3}\end{array}$ & \begin{tabular}{|l|} 
There are 209 \\
possible compounds \\
of PCB's. An \\
estimated 4 to 70 \\
different PCB \\
compounds can be \\
present in \\
commerial mixrures. \\
Inhalation of levels \\
$>10 \mathrm{mg}^{\mathrm{m}} \mathrm{m}^{\mathrm{a}}$ are \\
reported to be \\
unbearable (irritation \\
to nose, throat, and \\
lungs).
\end{tabular} & $\begin{array}{l}\text { Insulation for electric } \\
\text { cables and wires; } \\
\text { production of electric } \\
\text { condensers; additives } \\
\text { for extreme pressure } \\
\text { lubricants, coating in } \\
\text { foundry use. }\end{array}$ & & $1.38-1.54$ & & 0.00133 & \\
\hline $\begin{array}{r}\text { Tributyl Phosphate } \\
\left(\mathrm{C}_{4} \mathrm{H}_{9} \mathrm{O}\right)_{3} \mathrm{PO}\end{array}$ & $\begin{array}{l}\text { Phosphoric acid tributyl } \\
\text { ester; trin-butyl phosphate, } \\
\text { TBP }\end{array}$ & 293 & $\begin{array}{c}0.2 \\
(2.5 \\
\left.\mathrm{mg} / \mathrm{m}^{3}\right)\end{array}$ & $5.0 \mathrm{mg} / \mathrm{m}^{3}$ & $\begin{array}{l}1300 \\
\mathrm{mg} / \mathrm{m}^{3}\end{array}$ & $\begin{array}{l}\text { Inhalation can irritate } \\
\text { nose, throat, and } \\
\text { bronchial tubes and } \\
\text { cause headaches, } \\
\text { weakness, nausea, } \\
\text { collapse and even } \\
\text { death. }\end{array}$ & $\begin{array}{l}\text { Antifoaming agent } \\
\text { and plasticizer; } \\
\text { solvent in uranium } \\
\text { extraction; heat } \\
\text { exchange medium } \\
\text { and as a dielectric } \\
\text { malerial. }\end{array}$ & & & & & \\
\hline
\end{tabular}


Table F1. Properties of common contaminants at DOE facilities (Continued).

\begin{tabular}{|c|c|c|c|c|c|c|c|c|c|c|c|c|}
\hline \multirow[t]{2}{*}{ Chemical } & \multirow[t]{2}{*}{ Synonyms } & \multirow{2}{*}{$\begin{array}{l}\text { b.p. } \\
\left({ }^{\circ} \mathrm{C}\right)\end{array}$} & \multicolumn{3}{|c|}{$\begin{array}{c}\text { Permissible Exposure limits } \\
\text { in Air } \\
\text { (Federal standard) }\end{array}$} & \multirow[t]{2}{*}{ Notes } & \multirow[t]{2}{*}{ Uses } & \multirow[t]{2}{*}{$\begin{array}{c}\text { Molecular } \\
\text { weight }\end{array}$} & \multirow{2}{*}{$\begin{array}{c}\text { Density } \\
\mathrm{g} / \mathrm{ml}\end{array}$} & \multirow[t]{2}{*}{$\begin{array}{l}\text { Solubility } \\
\text { in water }\end{array}$} & \multirow{2}{*}{$\begin{array}{l}\text { Vapor } \\
\text { pressure } \\
(\text { mbar) }\end{array}$} & \multirow{2}{*}{$\begin{array}{l}\text { Diffusivity } \\
\left(\mathrm{cm}^{2} / \mathrm{s}\right)\end{array}$} \\
\hline & & & $\begin{array}{l}\text { TWA } \\
\text { (ppm) }\end{array}$ & $\begin{array}{l}\text { STEL } \\
\text { (ppm) }\end{array}$ & $\begin{array}{l}\text { IDLH } \\
(\mathrm{ppm})\end{array}$ & & & & & & & \\
\hline \multicolumn{13}{|l|}{ Other (Cont.) } \\
\hline $\begin{array}{l}\text { Acetonitrile } \\
\mathrm{CH}_{3} \mathrm{CN}\end{array}$ & $\begin{array}{l}\text { Methyl cyanide; } \\
\text { ethanenitrile; } \\
\text { cyanomethane }\end{array}$ & 82 & $\begin{array}{r}40-P E L \\
(70 \\
\left.\mathrm{mg} / \mathrm{m}^{3}\right)\end{array}$ & $\begin{array}{c}60 \\
(105 \\
\left.\mathrm{mg} / \mathrm{m}^{3}\right)\end{array}$ & 4,000 & $\begin{array}{l}\text { Compound has a rela- } \\
\text { tively low acute } \\
\text { toxicity, but there have } \\
\text { been reports of severe } \\
\text { and fatal poisonings } \\
\text { after inhalation of high } \\
\text { concentrations. }\end{array}$ & $\begin{array}{l}\text { Extractant for } \\
\text { animal and } \\
\text { vegetable oils; } \\
\text { solvent in the } \\
\text { pharmaceutical } \\
\text { industry; chememical } \\
\text { intermediate in } \\
\text { pesticide } \\
\text { manufacture. }\end{array}$ & 41.05 & 0.79 & - & 97 & 0.1181 \\
\hline $\begin{array}{l}\text { Isopropyl Alcohol } \\
\mathrm{CH}_{3} \mathrm{CHOHCH}_{3}\end{array}$ & $\begin{array}{l}\text { 2-Propanol; } \\
\text { isopropanol; } \\
\text { secondary propyl alcohol; } \\
\text { dimethyl carbinol; IPA }\end{array}$ & 82.5 & $\begin{array}{c}400 \\
(980 \\
\left.\mathrm{mg} / \mathrm{m}^{3}\right)\end{array}$ & $\begin{array}{c}500 \\
(1225 \\
\left.\mathrm{mg} / \mathrm{m}^{3}\right)\end{array}$ & 20,000 & $\begin{array}{l}\text { Irritation of the nose } \\
\text { and throat may occur } \\
\text { with inhalation }>400 \\
\text { ppm. }\end{array}$ & $\begin{array}{l}\text { Use in liniments, } \\
\text { skin lotions, } \\
\text { cosmetics, phar- } \\
\text { maceuticals and } \\
\text { hair tonics; solvent }\end{array}$ & 60.11 & 0.79 & $\cdot$ & 41.6 & 0.1013 \\
\hline $\begin{array}{l}\text { Tetrahydrofuran } \\
\mathrm{C}_{9} \mathrm{H}_{8} \mathrm{O}\end{array}$ & $\begin{array}{l}\text { Diethylene oxide; } \\
\text { tetramethylene oxide; THF; } \\
\text { 1,4-epoxybutane; } \\
\text { cyclotetramethylene oxide; } \\
\text { oxacyclopentane }\end{array}$ & 66 & $\begin{array}{c}200 \\
(590 \\
\left.\mathrm{mg} / \mathrm{m}^{3}\right)\end{array}$ & $\begin{array}{l}250 \\
(735 \\
\left.\mathrm{mg} / \mathrm{m}^{3}\right)\end{array}$ & 20,000 & $\begin{array}{l}\text { Vapors irritate the } \\
\text { eyes, nose, throat, and } \\
\text { lungs; high exposure } \\
\text { can cause } \\
\text { unconsciousness and } \\
\text { rapid death. }\end{array}$ & $\begin{array}{l}\text { Solvent to dissolve } \\
\text { synthetic resius. }\end{array}$ & 72.11 & 0.89 & & 200 & 0.0933 \\
\hline $\begin{array}{l}\text { Carbon Disulfide } \\
\mathrm{CS}_{2}\end{array}$ & $\begin{array}{l}\text { Carbon bisulfide; } \\
\text { dithiocarbonic anhydride }\end{array}$ & 46 & $\begin{array}{c}10 \\
(30 \\
\mathrm{mg} / \mathrm{m} 3)\end{array}$ & & 500 & $\begin{array}{l}\text { Alcoholics and those } \\
\text { suffering from } \\
\text { neurophysic trouble } \\
\text { are at special risk }\end{array}$ & $\begin{array}{l}\text { Used in } \\
\text { manufacture of } \\
\text { viscouse rayon, } \\
\text { ammonium salts, } \\
\text { flotation agents, } \\
\text { soil disinfectants, } \\
\text { dyes, paints, } \\
\text { explosives, etc.; } \\
\text { solvent for fats, } \\
\text { waxes, lacquers, } \\
\text { resins, etc.; used in } \\
\text { degreasing, } \\
\text { chemical analysis, } \\
\text { electroplatiang, } \\
\text { grain fumigation, } \\
\text { and dry-cleaning. }\end{array}$ & 76.14 & 1.26 & soluble & 397 & $\overline{0.1013}$ \\
\hline
\end{tabular}




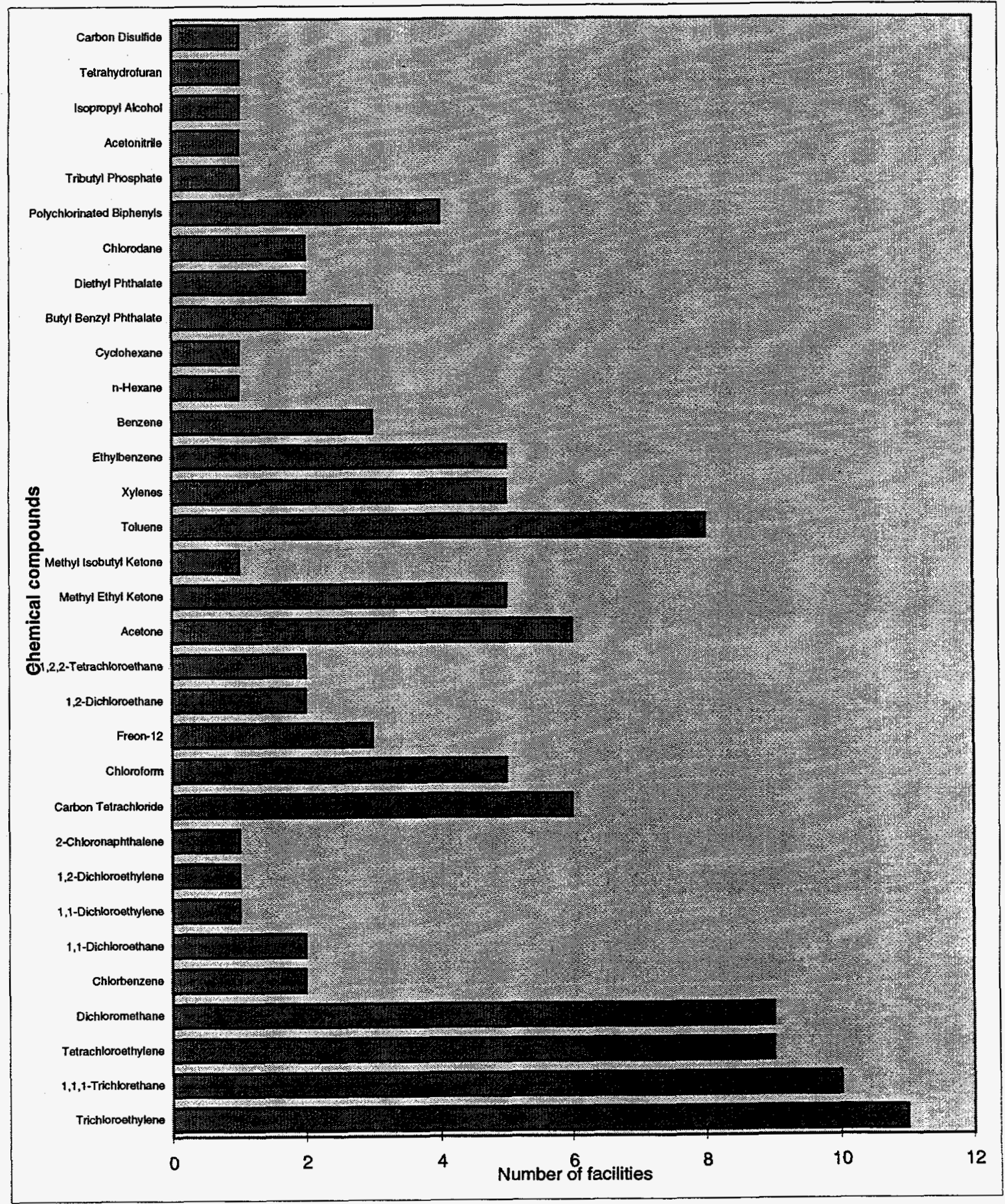

Figure F1. Frequency of occurrence in soils of common DOE contaminants for 18 facilities reviewed. 


\begin{tabular}{|l|}
\hline $\begin{array}{l}\text { Table F2. Non-EPA priority toxic pollutants included in the } \\
\text { study of chemical contaminants at DOE sites. }\end{array}$ \\
\hline Freon-12 \\
Acetone \\
Methyl ethyl ketone \\
Methyl isobutyl ketone \\
Xylenes \\
n-Hexane \\
Cychlohexane \\
Tributylphosphate \\
Acetonitrile \\
Isopropyl alcohol \\
Tetrahydrofuran \\
Carbon disulfide \\
\hline
\end{tabular}


Table F3. List of EPA priority toxic pollutants.

Under paragraph 11 of the Consent Decree in Natural Resources Defense Council, et al. v. Train, (G4) EPA must publish criteria for 65 specified toxic pollutants. The criteria are to state maximum recommended concentrations consistent with the protection of aquatic life and human health. They are as follows:

(1) Acenaphthene

(2) Acrolein

(3) Acrylonitrile

(4) Aldrin/Dieldrin

(5) Arsenic and compounds

(6) Antimony and compounds

(7) Asbestos

(8) Benzene

(9) Benzidine

(10) Beryllium and compounds

(11) Cadmium and compounds

(12) Carbon tetrachloride

(13) Chlordane (technical mixture and metabolites)

(14) Chlorinated benzenes (other than dichlorobenzenes)

(15) Chlorinated ethanes (including 1,2dichloroethane, 1,1,1-tricholorethane, and hexachloroethane)

(16) Chloroalkyl ethers (chloromethyl, chloroethyl, and mixed ethers)

(17) Chlorinated naphthalenes

(18) Chlorinated phenols (other than those listed elsewhere; includes trichlorophenols and chlorinated cresols)

(19) Chloroform

(20) 2-Chlorophenol

(21) Chromium and compounds

(22) Copper and compounds

(23) Cyanides

(24) DDT and metabolites

(25) Dichlorobenzenes (1,2-, 1,3-, and 1,4dichlorobenzenes)

(26) Dichlorobenzidine

(27) Dichlorethylenes (1,1-, and 1,-2dichloroethylene)

(28) 2,4-Dichlorophenol

(29) Dichloropropane and dichloropropene

(30) 2,4-Dimethylphenol

(31) Dinitrotoluene

(32) Diphenylhydrazine

(33) Endosulfan and metabolites
(34) Endrin and metabolites

(35) Ethylbenzene

(36) Fluoranthene

(37) Heloethers (other than those listed elsewhere; includes chlorophenyl phenyl ethers, bromophenyl phenyl ether, bis(dichloroisopropyl) ether, bis(chloroethoxy) methane and polychlorinated diphenyl ethers)

(38) Halomethanes (other than those listed elsewhere; includes methylene chloride, methychloride, methylbromide, bromoform, dichlorobromomethane, trichlorofluoromethane, dichlorodifluoromethane.)

(39) Heptachlor and metabolites

(40) Hexachlorobutadiene

(41) Hexachlorocyclohexane

(42) Hexachlorocyclopentadiene

(43) Isophorone

(44) Lead and compounds

(45) Mercury and compounds

(46) Naphthalene

(47) Nickel and compounds

(48) Nitrobezene

(49) Nitrophenols (including 2,4-dinitrophenol, dinitrocresol)

(50) Nitrosamines

(51) Pentachlorophenol

(52) Phenol

(53) Pthahlalate esters

(54) Polychlorinated biphenyls (PCBs)

(55) Polynuclear aromatic hydrocarbons (including benzoanthracenes, benzopyrenes, benzofluoranthene, chrysenes, dibenzoanthrancenes, and indenopyrenes ) (PAHs)

(56) Selenium and compounds

(57) Silver and compounds

(58) 2,3,7,8-tetrachlorodibenzo-p-dioxin (TCDD)

(59) Tetrachloroethylene

(60) Thallium and compounds

(61) Toluene

(62) Toxaphene

(63) Trichlorethylene

(64) Vinyl chloride

(65) Zinc and compounds 
Table F4. Specific toxic pollutants defined by the EPA.
(1) *acenaphthene (solid)
(2) *acrolein
(3) *acrylonitrile
(4) *benzene (Tl)
(5) *benzidine (solid)
(6) *carbon tetrachloride (T) (tetrachloromethane)

*chlorinated benzenes (other than dichlorobenzenes)

(7) chlorobenzene (Tl)

(8) 1,2,4--trichlorobenzene

(9) hexachlorobenzene (solid)

*chlorinated ethanes (including 1,2-dicholoroethane, 1,1,1-trichloroethane, and hexachloroethane)

(10) 1,2-dichloroethane (Tl)

(11) 1,1,1-trichloroethane (Tl)

(12) hexachloroethane (solid)

(13) 1,1-dichloroethane ( $\mathrm{Tl})$

(14) 1,1,2-trichloroethane

(15) 1,1,2,2-tetrachlorethane

(16) chloroethane

*chloroalkyl ethers (chloromethyl, chloroethyl, and mixed ethers)

(17) bis(chloromethyl) ether

(18) bis(2-chloroethyl) ether

(19) 2-chloroethyl vinyl ether (mixed)

*chlorinated naphthalenes

(20) 2-chloronaphthalene (Tl)

*chlorinated phenols (other than those listed elsewhere, includes trichlorophends and chlorinated cresols)

(21) 2,4,6-trichlorophenol (solid)

(22) para-chloro meta-cresol (solid)

(23) *chloroform (trichloromethane)

(T1)

(24) *2-chlorophenol

*dichlorobenzenes

(25) 1,2-dichlorobenzene

(26) 1,3-dichlorobenzene

(27) 1,4-dichlorobenzene (solid)

*dichlorobenzidine

(28) 3,3'-dichlorobenzidine (solid)

*dichloroethylenes (1,1-dichloroethylene

and 1,2-trans-dichloroethylene)

(29) 1,1-dichloroethylene (TI)

(30) 1,2-trans-dichloroethylene

(31) *2,4-dichlorophenol (solid)

*dichloropropane and dichloropropene

(32) 1,2-dichloropropane

(33) 1,2-dichloropropylene (1,2-dichloropropene)

(34) *2,4-dimethylphenol (solid)

*dinitrotoluene

(35) 2,4-dinitrotoluene (solid)

(36) 2,6-dinitrotoluene (solid)
(37) *1,2-diphenylhydrazine (solid)

(38) *ethylbenzene (Tl)

(39) *fluoranthene (solid)

*haloethers (other than those listed elsewhere)

(40) 4-chlorophenyl phenyl ether

(41) 4-bromophenyl phenyl ether

(42) bis(2-chloroisopropyl) ether

(43) bis(2chloroethoxy) methane

*halomethanes (other than those listed elsewhere)

(44) methylene chloride (dichloromethane)

(45) methyl chloride (chloromethane)

(46) methyl bromide (bromomethane)

(47) bromoform (tribromomethane)

(48) dichlorobromomethane

(49) trichlorofluoromethane

(50) dichlorodifluoromethane

(51) chlorodibromomethane

(52) *hexacholorobutadiene

(53) *hexachlorocyclopentadiene

(54) *isophorone

(55) *nitrobenzene

(56) napthalene (solid)

*nitrophenols (including 2,4-dinitrophenol and dinitrocresol)

(57) 2-nitrophenol (solid)

(58) 4-nitrophenol (solid)

(59) 2,4-dinitrophenol (solid)

(60) 4,6-dinitro-o-cresol (solid)

*nitrosamines

(61) N-nitrosodimethylamine

(62) N-nitrosodiphenylamine

(63) N-nitrosodi- -propylamine

(64) *pentachlorophenol (solid)

(65) *phenol (solid)

${ }^{*}$ phthalate esters

(66) bis(2-ethylhexyl) phthalte

(67) butyl benzyl phthalate (Tl)

(68) di-n-butyl phthalate

(69) di-n-octyl phthalate

(70) diethyl phthalate

(71) dimethyl phthalate (TI)

* polynuclear aromatic hydrocarbons

(72) benzo(a)anthracene (1,2-benzanthracene)

(73) benzo[a]lpyrene (3,4-benzopyrene) (solid)

(74) 3,4-benzofluoranthene

(75) benzo(k) fluoranthene (11,12-benzofluoranthene)

(76) chrysene (solid)

(77) acenaphthylene

(78) anthracene (solid)

(79) benzo(ghi)perylene (1,12-benzoperylene) 
Table F4. Specific toxic pollutants defined by the EPA(Continued).

(80) fluorene

(81) phenanthrene

(82) dibenzo(a,h)anthracene

(1,2,5,6-dibenzanthracene)

(83) indeno( $1,2,3,-$ cd)pyrene

(84) pyrene

(85) *tetrachloroethylene (Tl)

(86) *toluene (TI)

(87) *trichloroethylene (Tl)

(88) *vinyl chloride (chloroethylene)

*pesticides and metabolites

(89) *aldrin (solid)

(90) *dieldrin (solid)

(91) *chlordane (technical mixture and metabolites) (T1)

*DDT and metabolites

(92) 4,4'-DDT (solid)

(93) 4,4'-DDE (p,p'-DDX) (solid)

(94) 4,4'-DDD ( $\mathrm{p}, \mathrm{p}^{\prime}$-TDE) (solid)

*endosulfan and metabolites

(95) a-endosulfan-Alpha (solid)

(96) b-endosulfan-Beta (solid)

(97) endosulfan sulfate (solid)

*endrin and metabolites

(98) endrin (solid)

(99) endrin alehyde (solid)

*heptachlor and metabolites

(100) heptachlor (solid)

(101) heptachlor epoxide (solid)

*hexachlorocyclohexane (all isomers)

(102) a-BHC-Alpha (solid)
(103) b-BHC-Beta (solid)

(104) r-BHC (lindane)-Gamma (solid)

(105) g-BHC-Delta (solid)

*polychlorianted biphenyls (PCBs)

(106) PCB-1242 (Aroclor 1242)

(107) PCB-1254 (Aroclor-1254)

(108) PCB-1221-Aroclor-1221)

(109) PCB-1232-Aroclor-1232)

(110) PCB-1248-Aroclor-1248)

(111) PCB-1260-Aroclor-1260)

(112) PCB-1016-Aroclor-1016)

(113) *toxaphene (solid)

(114) *antimony (total) (solid)

(115) *arsenic (total) (solid)

(116) *asbestos (fibrous) (solid)

(117) *beryllium (total) (solid)

(118) * cadmium (total) (solid)

(119) * chromium (total) (solid)

(120) *copper (total) (solid)

(121) *cyanide (total) (solid)

(122) *lead (total) (solid)

(123) *mercury (total)

(124) *nickel (total) (solid)

(125) * selenium (total) (solid)

(126) *silver (total) (solid)

(127) *thallium (total) (solid)

(128) *zinc (total) (solid)

(129) $* * 2,3,7,8$-tetrachlorodibenzo-pdioxin (solid)

* Specific compounds and chemical classes as listed in the consent decree.

**This compound was specifically listed in the consent decree; however, due to its extreme toxicity

it is recommended that laboratories not acquire an analytical standard for this compound. 
Table F5. Properties of EPA priority pollutants.

\begin{tabular}{|c|c|c|c|c|c|c|c|c|c|c|c|c|}
\hline \multirow[t]{2}{*}{ Chemical } & \multirow[t]{2}{*}{ Synonyms } & \multirow{2}{*}{$\begin{array}{l}\text { b.p. } \\
\left({ }^{\circ} \mathrm{C}\right)\end{array}$} & \multicolumn{3}{|c|}{$\begin{array}{c}\text { Permissible Exposure } \\
\text { limits in Air } \\
\text { (Federal standard) } \\
\end{array}$} & \multirow[t]{2}{*}{ Notes } & \multirow[t]{2}{*}{ Uses } & \multirow[t]{2}{*}{$\begin{array}{l}\text { Molecular } \\
\text { weight }\end{array}$} & \multirow{2}{*}{$\begin{array}{c}\text { Density } \\
\mathrm{g} / \mathrm{ml}\end{array}$} & \multirow[t]{2}{*}{$\begin{array}{l}\text { Solubility } \\
\text { in water }\end{array}$} & \multirow{2}{*}{$\begin{array}{c}\text { Vapor } \\
\text { pressure } \\
\text { (mbar) }\end{array}$} & \multirow{2}{*}{$\begin{array}{c}\text { Diffusivity } \\
\left(\mathrm{cm}^{2} / \mathrm{s}\right)\end{array}$} \\
\hline & & & $\begin{array}{l}\text { TWA } \\
\text { (ppm) }\end{array}$ & $\begin{array}{l}\text { STEL } \\
\text { (ppm) } \\
\end{array}$ & $\begin{array}{l}\text { IDLH } \\
\text { (ppm) } \\
\end{array}$ & & & & & & & \\
\hline \multicolumn{13}{|c|}{ Chlorinated Hydrocarbons } \\
\hline $\begin{array}{l}\text { Acrolein } \\
\qquad \mathrm{CH}_{2}=\mathrm{CH}-\mathrm{CHO}\end{array}$ & $\begin{array}{l}\text { Acrylaldehyde } \\
\text { Acrylic aldehydes } \\
\text { Allyl aldehydes } \\
\text { Propenal }\end{array}$ & 52.5 & .1 & 3 & 5 & $\begin{array}{l}\text { Extremely toxic; } \\
\text { inhalation of air } \\
\text { containing } 10 \mathrm{ppm} \\
\text { may be fatal in a few } \\
\text { minutes; has a pierc- } \\
\text { ing, disagreeable } \\
\text { odor and causes } \\
\text { tears. }\end{array}$ & $\begin{array}{l}\text { As a biocide for } \\
\text { aquatic weed control; } \\
\text { algae and weed } \\
\text { control in process } \\
\text { water systems; } \\
\text { protect liquid fuels } \\
\text { against } \\
\text { microorganisms. } \\
\text { Intermediate in pro- } \\
\text { duction of glycerin. }\end{array}$ & 56.1 & .845 & $20.8 \% @ 30^{\circ} \mathrm{C}$ & $\begin{array}{l}286(215 \\
\mathrm{mm} @ \\
\left.20^{\circ} \mathrm{C}\right)\end{array}$ & \\
\hline $\begin{array}{l}\text { Acrylonitrile } \\
\qquad \mathrm{CH}_{2}=\mathrm{CH}-\mathrm{CN}\end{array}$ & $\begin{array}{l}\text { Vinyl cyanide } \\
\text { cyanoethylene } \\
\text { propene nitrile } \\
\text { AN }\end{array}$ & 77.3 & 2 & 10 & 4 & $\begin{array}{l}\text { Causes redness, } \\
\text { blisters and some } \\
\text { septemic signs; } \\
\text { classified as very } \\
\text { toxic, toxic concen- } \\
\text { tration has been } \\
\text { reported at } \\
16 \mathrm{ppm} / 20 \text { minutes. }\end{array}$ & $\begin{array}{l}\text { Manufacture of } \\
\text { synthetic fibers, } \\
\text { acrylostyrene and } \\
\text { other plastics, nitrile } \\
\text { rubbers and adhe- } \\
\text { sives; as a pesticide. }\end{array}$ & 53.1 & .806 & & 124 & .1059 \\
\hline $\begin{array}{l}\text { 1,2,4-Trichlorobenzene } \\
\mathrm{C}_{6} \mathrm{H}_{3} \mathrm{Cl}_{3}\end{array}$ & Unsym-trichlorobenzene & 213.5 & 5 & 5 & & $\begin{array}{l}\text { Short term inhalation } \\
\text { may cause irritation } \\
\text { to the nose and } \\
\text { throat, nervousness, } \\
\text { restlessness, tumors } \\
\text { and increased heart } \\
\text { rate. }\end{array}$ & $\begin{array}{l}\text { A dye-carrier, herbi- } \\
\text { cide intermediate, a } \\
\text { leat transfer medium, } \\
\text { dielectric fluid in } \\
\text { transformers and a } \\
\text { degreaser. }\end{array}$ & 181.5 & 1.454 & & .26 & \\
\hline $\begin{array}{l}\text { 1,1,2-Trichloroethane } \\
\mathrm{CH}_{2} \mathrm{Cl}-\mathrm{CHCl}_{2}\end{array}$ & $\begin{array}{l}\text { Vinyl trichloride } \\
\text { beta-trichloroethane }\end{array}$ & 113.7 & 10 & 20 & 500 & $\begin{array}{l}\text { Short term inhalation } \\
\text { may produce head- } \\
\text { ache, lassitude, } \\
\text { dizziness, in } \\
\text { coordination, coma, } \\
\text { and death; death may } \\
\text { result from } 13,600 \\
\text { ppm for } 2 \text { hours. }\end{array}$ & $\begin{array}{l}\text { Used as a chemical } \\
\text { intermediate and as a } \\
\text { solvent }\end{array}$ & 133.4 & 1.441 & slightly & 29 & 0.0792 \\
\hline $\begin{array}{l}\text { Chloroethane } \\
\qquad \mathrm{CH}_{3}-\mathrm{CH}_{2} \mathrm{Cl}\end{array}$ & Monochloroethane & 12.2 & 1000 & & & & $\begin{array}{l}\text { Solvent; degreasing } \\
\text { agent; fumigant; } \\
\text { cutting fluid }\end{array}$ & 64.5 & 0.921 & $5.74 \mathrm{~g} / 1$ & $\begin{array}{l}1.33 \\
(1000 \mathrm{~mm} \\
\mathrm{Hg} @ \\
\left.20^{\circ} \mathrm{C}\right) \\
\end{array}$ & .1036 \\
\hline
\end{tabular}


Table F5. Properties of EPA priority pollutants (Continued).

\begin{tabular}{|c|c|c|c|c|c|c|c|c|c|c|c|c|}
\hline \multirow[t]{2}{*}{ Chemical } & \multirow[t]{2}{*}{ Synonyms } & \multirow{2}{*}{$\begin{array}{l}\text { b.p. } \\
\left({ }^{\circ} \mathbf{C}\right)\end{array}$} & \multicolumn{3}{|c|}{$\begin{array}{c}\text { Permissible Exposure } \\
\text { limits in Air } \\
\text { (Federal standard) }\end{array}$} & \multirow[t]{2}{*}{ Notes } & \multirow[t]{2}{*}{ Uses } & \multirow[t]{2}{*}{$\begin{array}{c}\text { Molecular } \\
\text { weight }\end{array}$} & \multirow{2}{*}{$\begin{array}{l}\text { Density } \\
\mathrm{g} / \mathrm{ml}\end{array}$} & \multirow[t]{2}{*}{$\begin{array}{l}\text { Solubility } \\
\text { in water }\end{array}$} & \multirow{2}{*}{$\begin{array}{c}\text { Vapor } \\
\text { pressure } \\
\text { (mbar) }\end{array}$} & \multirow{2}{*}{$\begin{array}{l}\text { Diffusivity } \\
\left(\mathrm{cm}^{2} / \mathrm{s}\right)\end{array}$} \\
\hline & & & $\begin{array}{l}\text { TWA } \\
(\mathrm{ppm}) \\
\end{array}$ & $\begin{array}{l}\text { STEL } \\
(\mathrm{ppm}) \\
\end{array}$ & $\begin{array}{l}\text { IDLH } \\
(\mathrm{ppm})\end{array}$ & & & & & & & \\
\hline \multicolumn{13}{|l|}{$\begin{array}{l}\text { Chlorinated Hydrocarbons } \\
\text { (Cont) }\end{array}$} \\
\hline $\begin{array}{l}\text { Bis(chloromethyl) ether } \\
\qquad \mathrm{CICH}_{2} \cdot 0 \cdot \mathrm{CH}_{2} \mathrm{Cl}\end{array}$ & $\begin{array}{l}\text { BCME } \\
\text { symdichloromethyl ether } \\
\text { dichloromethyl ether }\end{array}$ & 106 & .001 & & & $\begin{array}{l}\text { Has a suffocating } \\
\text { odor; incompatible } \\
\text { with water; a known } \\
\text { human carcinogen- } \\
\text { all contact should be } \\
\text { avoided. }\end{array}$ & $\begin{array}{l}\text { An alkylatting agent } \\
\text { in the manufacture of } \\
\text { polymers; ; solvent } \\
\text { for polymerization } \\
\text { reactions; in prepara- } \\
\text { tion of ion exchange } \\
\text { resins; intermediate } \\
\text { for organic synthesis. }\end{array}$ & 115.0 & 1.315 & incompatible & & \\
\hline $\begin{array}{l}\text { Bis(2-chloroethyl) ether } \\
\qquad \mathrm{ClCH}_{2}-\mathrm{CH}_{2}-0-\mathrm{CH}_{2}-\mathrm{CH}_{2} \mathrm{Cl}\end{array}$ & $\begin{array}{l}\text { Dichloroether; } \\
\text { dichloroethyl oxide; sym- } \\
\text { dichloroethyl ether; } \\
\text { Dichloroethyl lether; 2- } \\
\text { 2'dichloroethyl eiher, } \\
\text { BCLEE; Chlorex@ }\end{array}$ & 178 & 5 & 10 & 250 & $\begin{array}{l}\text { Al concentrations } \\
\text { above } 500 \text { ppm, } \\
\text { coughing, rething, } \\
\text { and voriting may } \\
\text { occur, as well as } \\
\text { profuse tearing; } \\
\text { irritation at lower } \\
\text { concentrations; very } \\
\text { toxic }\end{array}$ & $\begin{array}{l}\text { In manufacture of } \\
\text { paint, varnish, } \\
\text { lacquer, soap and } \\
\text { finish remover; in dry } \\
\text { cleaning; as a solvent } \\
\text { for cellulose esters, } \\
\text { naphthalenes, oils, } \\
\text { fats, greases, tar, and } \\
\text { gumm textile scouring; } \\
\text { soil fumigation. } \\
\end{array}$ & 143.0 & 1.220 & & 1.07 & .0694 \\
\hline $\begin{array}{l}\text { 2-Chloroethyl vinyl ether (mixed) } \\
\mathrm{ClCh}_{2} \mathrm{Ch}_{2} \mathrm{OCH}=\mathrm{CH}_{2}\end{array}$ & $\begin{array}{l}\text { Vinyl 2-chloroethyl ether; } \\
\text { (2-chloroethoxy) ethane }\end{array}$ & 109 & $\begin{array}{c}\text { not } \\
\text { defined }\end{array}$ & $\begin{array}{c}\text { not } \\
\text { defined }\end{array}$ & & $\begin{array}{l}\text { Very little data is } \\
\text { available }\end{array}$ & $\begin{array}{l}\text { In manufacture of } \\
\text { anesthetics, } \\
\text { sedatives, and } \\
\text { cellulose ethers }\end{array}$ & & & & & \\
\hline $\begin{array}{l}\text { 2-Chlorophenol } \\
\mathrm{HOC}_{6} \mathrm{H}_{4} \mathrm{C}_{1}\end{array}$ & & 175 & & & & $\begin{array}{l}\text { Short term inhalation } \\
\text { can cause severe } \\
\text { irritation, burns to } \\
\text { the nose and throat, } \\
\text { headache, vomiting, } \\
\text { lung damage, muscle } \\
\text { twitchings, spasms, } \\
\text { tremors, and collapse }\end{array}$ & $\begin{array}{l}\text { Intermediate in the } \\
\text { production of other } \\
\text { chemicals } \\
\text { (fungicides, } \\
\text { antiseptics, disinfec- } \\
\text { tants, and wood and } \\
\text { glue preservatives) } \\
\end{array}$ & 128.4 & 1.257 & & $\begin{array}{l}1 \mathrm{~mm} \mathrm{Hg} \\
@ 12.1^{\circ} \mathrm{C}\end{array}$ & \\
\hline $\begin{array}{l}\text { 1,2-Dichlorobenzene } \\
\mathrm{C}_{6} \mathrm{H}_{4} \mathrm{Cl}_{2}\end{array}$ & $\begin{array}{l}\text { 1,2-Dichloro-o DCB } \\
\text { 1,2-DCB } \\
\text { ODB } \\
\text { ODCB } \\
\text { Dowtherm E } \otimes\end{array}$ & 180.5 & 25 & 50 & 1.700 & $\begin{array}{l}\text { Exposure can cause } \\
\text { hedaches, } \\
\text { dizziness, swelling } \\
\text { of eyes, hands ind } \\
\text { feet, and nausea. } \\
\text { Higher levels can } \\
\text { cause severe liver } \\
\text { damage and death. } \\
\end{array}$ & $\begin{array}{l}\text { Process solvent in } \\
\text { manufacturing of } \\
\text { toluene diisocyanate; } \\
\text { intermediate in the } \\
\text { synthesis of } \\
\text { dyestuffs, herbicides } \\
\text { and degreasers. }\end{array}$ & 147.0 & 1.298 & $.145 \mathrm{~g} / @ 25^{\circ} \mathrm{C}$ & $\begin{array}{l}1.3 \\
(1 \mathrm{~mm} \mathrm{Hg} \\
\left(020^{\circ} \mathrm{C}\right)\end{array}$ & .0668 \\
\hline
\end{tabular}


Table F5. Properties of EPA priority pollutants (Continued).

\begin{tabular}{|c|c|c|c|c|c|c|c|c|c|c|c|c|}
\hline \multirow[t]{2}{*}{ Chemical } & \multirow[t]{2}{*}{ Synonyms } & \multirow{2}{*}{$\begin{array}{l}\text { b.p. } \\
\left({ }^{\circ} \mathbf{C}\right)\end{array}$} & \multicolumn{3}{|c|}{$\begin{array}{c}\text { Permissible Exposure } \\
\text { limits in Air } \\
\text { (Federal standard) } \\
\end{array}$} & \multirow[t]{2}{*}{ Notes } & \multirow[t]{2}{*}{ Uses } & \multirow[t]{2}{*}{$\begin{array}{l}\text { Molecular } \\
\text { weight }\end{array}$} & \multirow{2}{*}{$\begin{array}{c}\text { Density } \\
\mathrm{g} / \mathrm{ml}\end{array}$} & \multirow[t]{2}{*}{$\begin{array}{l}\text { Solubility } \\
\text { in water }\end{array}$} & \multirow{2}{*}{$\begin{array}{c}\text { Vapor } \\
\text { pressure } \\
\text { (mbar) }\end{array}$} & \multirow{2}{*}{$\begin{array}{l}\text { Diffusivity } \\
\left(\mathrm{cm}^{2} / \mathrm{s}\right)\end{array}$} \\
\hline & & & $\begin{array}{l}\text { TWA } \\
(\mathrm{ppm}) \\
\end{array}$ & $\begin{array}{l}\text { STEL } \\
(\mathrm{ppm}) \\
\end{array}$ & $\begin{array}{l}\text { IDLH } \\
\text { (ppm) }\end{array}$ & & & & & & & \\
\hline \multicolumn{13}{|c|}{$\begin{array}{l}\text { Chlorinated Hydrocarbons } \\
\text { (Cont) }\end{array}$} \\
\hline $\begin{array}{l}\text { 1,3-Dichlorobenzene } \\
\mathrm{C}_{6} \mathrm{H}_{4} \mathrm{Cl}_{2}\end{array}$ & $\begin{array}{l}\text { 1,3-Dichloro-m-DCB } \\
\text { 1,3-DCB }\end{array}$ & 173.0 & $\begin{array}{c}\text { not } \\
\text { defined }\end{array}$ & $\begin{array}{c}\text { not } \\
\text { defined }\end{array}$ & & & \begin{tabular}{|l} 
Information not \\
avaialable on use of \\
this sompound. \\
However, it may \\
occur as a contami- \\
nant of 1,2-DCB \\
formulations \\
\end{tabular} & 147.0 & 1.288 & $.123 \mathrm{~g} / 1 @ 25^{\circ} \mathrm{C}$ & $\begin{array}{l}2.2 \\
(5 \mathrm{~mm} \mathrm{Hg} \\
\left(39^{\circ} \mathrm{C}\right)\end{array}$ & \\
\hline $\begin{array}{l}\text { 1,2-Dichloropropane } \\
\mathrm{CH}_{2} \mathrm{Cl}-\mathrm{CHCl}-\mathrm{CH}_{3}\end{array}$ & $\begin{array}{l}\text { Propylene dichloride } \\
\text { ENT } 15406\end{array}$ & 96.8 & 75 & 110 & 2,000 & $\begin{array}{l}\text { When heated to } \\
\text { decomposition emits } \\
\text { highly toxic fumes of } \\
\text { phosgene. Vapor } \\
\text { can irritate the nose, } \\
\text { throat, eyes and air } \\
\text { passages. }\end{array}$ & $\begin{array}{l}\text { Soil fumigant for the } \\
\text { control of nematodes, } \\
\text { in oil and fat } \\
\text { solvents, and in dry } \\
\text { cleaning and } \\
\text { degreasing processes; } \\
\text { lead scavenger for } \\
\text { anti-knock fluids } \\
\end{array}$ & 113.0 & 1.156 & $\begin{array}{l}2.7 \mathrm{mg} / \mathrm{ml} \\
2020^{\circ} \mathrm{C}\end{array}$ & $\begin{array}{l}56 \\
(40 \mathrm{~mm} / \mathrm{Hg} \\
\left({ }^{\circ} 19.4^{\circ} \mathrm{C}\right)\end{array}$ & 0.0765 \\
\hline 1,2-Dichloropropylene & 1,2-dichloropropene & 77 & & & & & \begin{tabular}{|l|} 
Soil fumigant for the \\
control of nematodes; \\
in soil and fat sol- \\
vents, and in dry \\
cleaning and degreas- \\
ing process. \\
\end{tabular} & 111.0 & 1.182 & & & \\
\hline $\begin{array}{l}\text { Methyl chloride } \\
\quad \mathrm{CH}_{3} \mathrm{Cl}\end{array}$ & $\begin{array}{l}\text { chloromethane } \\
\text { monochloromethane }\end{array}$ & -23.8 & 50 & 100 & 10,000 & \begin{tabular}{|l|} 
Iliness has been \\
reported after inhala- \\
tion of \\
concentrations of \\
$500 \mathrm{pm} .10,000$ \\
ppm for 30 minutes \\
has caused death. \\
Can cause nausea, \\
vomiting, loss of \\
aappetite, headache, \\
diarthea, drooping \\
eye lids, and eye \\
iwich. Onset of \\
symptoms may be \\
delayed several \\
hours after exposure. \\
\end{tabular} & $\begin{array}{l}\text { As a methylating and } \\
\text { chlorinating agent in } \\
\text { organic chemistry; } \\
\text { extractant for } \\
\text { greases, oils and } \\
\text { resins in oil } \\
\text { refineries, solvent in } \\
\text { synthetic rubber } \\
\text { industry; a } \\
\text { refrigerant; an } \\
\text { intermediate in drug } \\
\text { manufacture. }\end{array}$ & 50.5 & .0023 & & 4.896 bars & .1276 \\
\hline
\end{tabular}


Table F5. Properties of EPA priority pollutants (Continued).

\begin{tabular}{|c|c|c|c|c|c|c|c|c|c|c|c|c|}
\hline \multirow[t]{2}{*}{ Chemical } & \multirow[t]{2}{*}{ Synonyms } & \multirow{2}{*}{$\begin{array}{l}\text { b.p. } \\
\left({ }^{\circ} \mathrm{C}\right)\end{array}$} & \multicolumn{3}{|c|}{$\begin{array}{c}\text { Permissible Exposure } \\
\text { limits in Air } \\
\text { (Federal standard) }\end{array}$} & \multirow[t]{2}{*}{ Notes } & \multirow{2}{*}{ Uses } & \multirow[t]{2}{*}{$\begin{array}{c}\text { Molecular } \\
\text { weight }\end{array}$} & \multirow{2}{*}{$\begin{array}{l}\text { Density } \\
\mathrm{g} / \mathrm{ml}\end{array}$} & \multirow[t]{2}{*}{$\begin{array}{l}\text { Solubility } \\
\text { in water }\end{array}$} & \multirow{2}{*}{$\begin{array}{c}\text { Vapor } \\
\text { pressure } \\
\text { (mbar) }\end{array}$} & \multirow{2}{*}{$\begin{array}{l}\text { Diffusivity } \\
\left(\mathrm{cm}^{2} / \mathrm{s}\right)\end{array}$} \\
\hline & & & $\begin{array}{l}\text { TWA } \\
\text { (ppm) }\end{array}$ & $\begin{array}{l}\text { STEL } \\
\text { (ppm) } \\
\end{array}$ & $\begin{array}{l}\text { IDLH } \\
\text { (ppm) } \\
\end{array}$ & & & & & & & \\
\hline \multicolumn{13}{|c|}{$\begin{array}{l}\text { Chlorinated Hydrocarbons } \\
\text { (Cont) }\end{array}$} \\
\hline $\begin{array}{l}\text { Methyl bromide } \\
\mathrm{CH}_{3} \mathrm{Br}\end{array}$ & $\begin{array}{l}\text { bromomethane } \\
\text { monobromomethane } \\
\text { Embafume(@) } \\
\text { Iscobrome(@) } \\
\text { Rotax@ }\end{array}$ & 3.6 & 5 & 15 & 2,000 & $\begin{array}{l}\text { Short term inhalation } \\
\text { of } 35 \text { ppm can cause } \\
\text { nausea, vomiting, } \\
\text { loss of appetite, } \\
\text { dizziness, drowsi- } \\
\text { ness, and dimming of } \\
\text { vision. Headaches, } \\
\text { dizziness, and weak- } \\
\text { ness can be felt at } \\
100 \text { ppm and can last } \\
\text { for months. Expo- } \\
\text { sures of } 10,000 \text { ppm } \\
\text { for a few minutes } \\
\text { can cause death. }\end{array}$ & $\begin{array}{l}\text { An insect fumigant } \\
\text { for soil, grain, ware- } \\
\text { houses, mills, ships, } \\
\text { etc.; chemical inter- } \\
\text { mediate and a methy- } \\
\text { lating agent; a refrig- } \\
\text { erant, a herbicide, a } \\
\text { fire extinguishing } \\
\text { agent, and an inter- } \\
\text { mediate in the mant- } \\
\text { facture of many. } \\
\text { drugs. }\end{array}$ & 94.9 & & . & 1.89 bars & 0.1096 \\
\hline $\begin{array}{l}\text { Bromoform } \\
\mathrm{CH} \mathrm{BR}\end{array}$ & $\begin{array}{l}\text { tri bromomethane } \\
\text { methyl tribromide }\end{array}$ & 149.5 & .5 & $\begin{array}{c}\text { not } \\
\text { defined }\end{array}$ & $\begin{array}{c}\text { not } \\
\text { defined }\end{array}$ & \begin{tabular}{|l|} 
Short term inhalation \\
can cause irritation \\
to the nose and \\
throat, tearing, \\
reddening of the \\
face, dizziness and \\
death. \\
\end{tabular} & \begin{tabular}{|l|} 
In pharmaceutical \\
manufacturing; as an \\
ingredient in fire \\
resistant chemicals \\
and gauge fluid; as a \\
solvent for waxes, \\
greases and oils
\end{tabular} & 252.7 & 2.890 & & 6.7 & .0767 \\
\hline Dichlorobromomethane & $\begin{array}{l}\text { dibromochloromethane } \\
\text { chlorodibromomethane } \\
\text { CDBM }\end{array}$ & 119 & $\begin{array}{c}\text { not } \\
\text { defined }\end{array}$ & $\begin{array}{c}\text { not } \\
\text { defined }\end{array}$ & $\begin{array}{c}\text { not } \\
\text { defined }\end{array}$ & $\begin{array}{l}\text { Very little toxicity } \\
\text { information is avail- } \\
\text { able. It is an irritant } \\
\text { and narcotic; symp- } \\
\text { toms include dizzi- } \\
\text { ness, headache, and } \\
\text { liver and kidney } \\
\text { damage. }\end{array}$ & $\begin{array}{l}\text { Chemical intermedi- } \\
\text { ate in the } \\
\text { manufacture of fire } \\
\text { extinguishing agents, } \\
\text { aerosol propellants, } \\
\text { refrigerants, and } \\
\text { pesticides. }\end{array}$ & & & & & \\
\hline $\begin{array}{l}\text { Trichlorofluoromethane } \\
\mathrm{CCl}_{3} \mathrm{~F}\end{array}$ & $\begin{array}{l}\text { Fluorotrichloromethane } \\
\text { Refrigerant } 11 \\
\text { monofluorotrichloro- } \\
\text { methane } \\
\text { trichloromonofluoro- } \\
\text { methane } \\
\text { Freon 11 } 1 \text {; F-11 } \\
\end{array}$ & 23.8 & & 1000 & & $\begin{array}{l}\text { Incoherence, } \\
\text { tremors, dermatitis, } \\
\text { frostbite, cardiac } \\
\text { arrhythmia, cardiac } \\
\text { arrest }\end{array}$ & $\begin{array}{l}\text { Used as a refrigerant } \\
\text {, aerosol propellant, } \\
\text { and foaming agent }\end{array}$ & 137.4 & 1.494 & & $8.865 \mathrm{bar}$ & .0858 \\
\hline
\end{tabular}


Table F5. Properties of EPA priority pollutants (Continued).

\begin{tabular}{|c|c|c|c|c|c|c|c|c|c|c|c|c|}
\hline \multirow{2}{*}{ Chemical } & \multirow{2}{*}{ Synonyms } & \multirow{2}{*}{$\begin{array}{l}\text { b.p. } \\
\left({ }^{\circ} \mathbf{C}\right)\end{array}$} & \multicolumn{3}{|c|}{$\begin{array}{c}\text { Permissible Exposure } \\
\text { limits in Air } \\
\text { (Federal standard) }\end{array}$} & \multirow[t]{2}{*}{ Notes } & \multirow[t]{2}{*}{ Uses } & \multirow[t]{2}{*}{$\begin{array}{c}\text { Molecular } \\
\text { weight }\end{array}$} & \multirow{2}{*}{$\begin{array}{l}\text { Density } \\
\mathrm{g} / \mathrm{ml}\end{array}$} & \multirow[t]{2}{*}{$\begin{array}{l}\text { Solubility } \\
\text { in water }\end{array}$} & \multirow{2}{*}{$\begin{array}{c}\text { Vapor } \\
\text { pressure } \\
\text { (mbar) }\end{array}$} & \multirow{2}{*}{$\begin{array}{l}\text { Diffusivity } \\
\left(\mathrm{cm}^{2} / \mathrm{s}\right)\end{array}$} \\
\hline & & & $\begin{array}{l}\text { TWA } \\
(\mathrm{ppm}) \\
\end{array}$ & $\begin{array}{l}\text { STELL } \\
(\mathrm{ppm}) \\
\end{array}$ & $\begin{array}{l}\text { IDLH } \\
\text { (ppm) } \\
\end{array}$ & & & & & & & \\
\hline \multicolumn{13}{|c|}{$\begin{array}{l}\text { Chlorinated Hydrocarbons } \\
\text { (Cont) }\end{array}$} \\
\hline $\begin{array}{l}\text { Dichlorodiffluoromethane } \\
\mathrm{CCl}_{2} \mathrm{~F}_{2}\end{array}$ & $\begin{array}{l}\text { Refigerent 12 } \\
\text { Freon 12®; F-12 } \\
\text { Propellant 12 } \\
\text { Halon 122, R-12 }\end{array}$ & -24.9 & 1000 & 1250 & 50,000 & $\begin{array}{l}\text { Inhalation can cause } \\
\text { dizziness, light } \\
\text { headiness, and } \\
\text { trouble } \\
\text { concentrating. } \\
\text { Exposure can cause } \\
\text { the heart to beat } \\
\text { irregularly or to stop, } \\
\text { which can cause } \\
\text { death. }\end{array}$ & $\begin{array}{l}\text { An aerosol } \\
\text { propellant, refrigerant } \\
\text { and foaming agent. }\end{array}$ & 120.9 & 1.328 & & $5.669 \mathrm{bar}$ & .0958 \\
\hline Chlorodibromomethane & & & & & & $\begin{array}{l}\text { Could not find any } \\
\text { information on this } \\
\text { compound. }\end{array}$ & & & & & & \\
\hline $\begin{array}{l}\text { Hexachlorobutadiene } \\
{ }_{\mathrm{C}_{4} \mathrm{Cl}_{6}}\end{array}$ & $\begin{array}{l}\text { perchlorobutadiene } \\
\text { 1,3-hexachlorobutdiene }\end{array}$ & 215 & .02 & & & $\begin{array}{l}\text { Should be handled as } \\
\text { a carcinogen-with } \\
\text { extreme caution; } \\
\text { may damage the } \\
\text { developing feres; } \\
\text { contact can iritate } \\
\text { and burn the eyes } \\
\text { and skin. }\end{array}$ & \begin{tabular}{|l|} 
By-product of the \\
manufacture of chlo- \\
rinated hydrocarbons \\
such as tetrachloro- \\
ethylene, trichloro- \\
ethylene, and carbon \\
tetrachloride; solvent \\
for organic sub- \\
stancess to recover \\
chlorine from "sniff" \\
gas.
\end{tabular} & & & $\begin{array}{c}\text { Se-3 mg/ml @ } \\
20^{\circ} \mathrm{C}\end{array}$ & $.15 \mathrm{~mm} \mathrm{Hg}$ & \\
\hline $\begin{array}{l}\text { Hexachlorobutadiene } \\
\mathrm{C}_{4} \mathrm{Cl}_{6}\end{array}$ & $\begin{array}{l}\text { perchlorobutadiene } \\
\text { 1,3-hexachlorobutdiene }\end{array}$ & 215 & .02 & & & $\begin{array}{l}\text { Should be handled as } \\
\text { a carcinogen-with } \\
\text { extreme caution; } \\
\text { may damage the } \\
\text { developing ferus; } \\
\text { contact can irritate } \\
\text { and burn the eyes } \\
\text { and skin. }\end{array}$ & $\begin{array}{l}\text { By-product of the } \\
\text { manufacture of chlo- } \\
\text { rinated hydrocarbons } \\
\text { such as tetrachloro- } \\
\text { ethylene, trichloro- } \\
\text { ethylene, and carbon } \\
\text { tetrachloride; solvent } \\
\text { for organic sub- } \\
\text { stances; to recover } \\
\text { chlorine from "sniff" } \\
\text { gas. }\end{array}$ & & & $\begin{array}{c}5 e-3 \mathrm{mg} / \mathrm{ml} @ \\
20^{\circ} \mathrm{C}\end{array}$ & $.15 \mathrm{~mm} \mathrm{Hg}$ & \\
\hline
\end{tabular}


Table F5. Properties of EPA priority pollutants (Continued).

\begin{tabular}{|c|c|c|c|c|c|c|c|c|c|c|c|c|}
\hline \multirow[t]{2}{*}{ Chemical } & \multirow[t]{2}{*}{ Synonyms } & \multirow{2}{*}{$\begin{array}{l}\text { b.p. } \\
\left({ }^{\circ} \mathrm{C}\right)\end{array}$} & \multicolumn{3}{|c|}{$\begin{array}{c}\text { Permissible Exposure } \\
\text { limits in Air } \\
\text { (Federal standard) }\end{array}$} & \multirow[t]{2}{*}{ Notes } & \multirow[t]{2}{*}{ Uses } & \multirow[t]{2}{*}{$\begin{array}{l}\text { Molecular } \\
\text { weight }\end{array}$} & \multirow{2}{*}{$\begin{array}{c}\text { Density } \\
\mathrm{g} / \mathrm{ml}\end{array}$} & \multirow[t]{2}{*}{$\begin{array}{l}\text { Solubility } \\
\text { in water }\end{array}$} & \multirow{2}{*}{$\begin{array}{c}\text { Vapor } \\
\text { pressure } \\
\text { (mbar) }\end{array}$} & \multirow{2}{*}{$\begin{array}{l}\text { Diffusivity } \\
\left(\mathrm{cm}^{2} / \mathrm{s}\right)\end{array}$} \\
\hline & & & $\begin{array}{l}\text { TWA } \\
\text { (ppm) }\end{array}$ & $\begin{array}{l}\text { STEL } \\
\text { (ppm) } \\
\end{array}$ & $\begin{array}{l}\text { IDLH } \\
(\mathrm{ppm}) \\
\end{array}$ & & & & & & & \\
\hline \multicolumn{13}{|c|}{$\begin{array}{l}\text { Chlorinated Hydrocarhons } \\
\underline{\underline{\text { Cont) }}}\end{array}$} \\
\hline $\begin{array}{l}\text { Hexachlorocyclopentadiene } \\
\mathrm{C}_{5} \mathrm{Cl}_{6}\end{array}$ & $\begin{array}{l}\text { Hex; C-56 } \\
1,2,3,4,5,55^{-} \\
\text {hexachlorocyclo- } \\
\text { pentadiene } \\
\text { HCCPD }\end{array}$ & 239 & .01 & .03 & & $\begin{array}{l}\text { Compound is very } \\
\text { toxic and may be } \\
\text { fatal if inhaled, } \\
\text { swallowed or } \\
\text { absorbed through } \\
\text { skin. Inhalation is } \\
\text { highly irritating to } 10 \\
\text { mucous membranes, } \\
\text { causing tearing, } \\
\text { sneezing, and saliva- } \\
\text { tion. }\end{array}$ & $\begin{array}{l}\text { Was used as } \\
\text { chemical intermediate } \\
\text { in the manufacture of } \\
\text { numerous widely } \\
\text { used pesticides; an } \\
\text { intermediate in the } \\
\text { synthesis of commer- } \\
\text { cially important flame } \\
\text { retardants }\end{array}$ & 272.7 & 1.712 & $.805 \mathrm{mg} /$ & $\begin{array}{l}1 \mathrm{~mm} \text { Hg at } \\
78^{\circ} \mathrm{C}\end{array}$ & \\
\hline $\begin{array}{l}\text { Isophorone } \\
\mathrm{C}_{9} \mathrm{H}_{14} \mathrm{O}\end{array}$ & $\begin{array}{l}\gamma \text {-isophorone } \\
\text { 3,5,5-trimethyl-2- } \\
\quad \text { cyclohexane--1-one } \\
\text { trimethyl cyclohexanone } \\
\text { isoacetophorone }\end{array}$ & 215.2 & 4 & 5 & 800 & $\begin{array}{l}\text { May cause head- } \\
\text { aches, nausea, and a } \\
\text { drunken feeling; } \\
\text { higher levels can } \\
\text { cause one to pass } \\
\text { out; may iritate the } \\
\text { eyes, nose, and } \\
\text { throat. } \\
\end{array}$ & $\begin{array}{l}\text { Solvent or cosolvent } \\
\text { for finishes, lacquers, } \\
\text { polyvinyl and nitro } \\
\text { cellulose resins, } \\
\text { pesticides, } \\
\text { herbicides, fats, oil, } \\
\text { and gums. }\end{array}$ & 138.2 & 0.922 & $12 \mathrm{~g} / \mathrm{I}$ & \begin{tabular}{|l|}
.33 \\
$6.31 \mathrm{~mm}$ \\
$\mathrm{Hg}$ at \\
$\left.20^{\circ} \mathrm{C}\right)$
\end{tabular} & .0602 \\
\hline $\begin{array}{l}\text { Nitrobenzene } \\
\quad \mathrm{C}_{6} \mathrm{H}_{5}-\mathrm{NO}_{2}\end{array}$ & $\begin{array}{l}\text { nitrobenzol } \\
\text { oil of mirbane } \\
\text { oil of bitter almonds }\end{array}$ & 210.9 & 1 & 2 & 200 & \begin{tabular}{|l|} 
Short-term exposure \\
by inhalation has \\
caused headache and \\
nausea a $3-6$ ppm. \\
40 ppm may cause \\
intoxication and \\
decrease ability of \\
blood to carry \\
oxygen; symptoms \\
may be delayed for \\
up to 4 hours.
\end{tabular} & $\begin{array}{l}\text { For reduction to } \\
\text { anolin (which is } \\
\text { widely used as an } \\
\text { ingredient for dyes, } \\
\text { rubber, and medi- } \\
\text { cines); in the manu- } \\
\text { facture of explosives, } \\
\text { in shoo and floor } \\
\text { polishes, leather } \\
\text { dressings; in paint } \\
\text { solvents, and to mask } \\
\text { other unpleasant } \\
\text { odors. } \\
\end{array}$ & 123.1 & 1.204 & $1 \mathrm{~g} /$ & $\begin{array}{l}.20(.340 \\
\mathrm{mm} \mathrm{Hg})\end{array}$ & \\
\hline $\begin{array}{c}\mathrm{N} \text {-nitrosodimethylamine } \\
\mathrm{O}=\mathrm{N}-\mathrm{N}\left(\mathrm{CH}_{3}\right)_{2}\end{array}$ & $\begin{array}{l}\text { Dimethylnitosamine } \\
\text { DMN } \\
\text { DMNA }\end{array}$ & 152 & $\begin{array}{c}\text { carcin- } \\
\text { ogen, } \\
\text { none } \\
\text { set }\end{array}$ & $\begin{array}{c}\text { carcin- } \\
\text { ogen, } \\
\text { none set }\end{array}$ & & $\begin{array}{l}\text { Carcinogen; may } \\
\text { cause nausea, vomit- } \\
\text { ing and malaise; } \\
\text { extremely high } \\
\text { toxicily }\end{array}$ & $\begin{array}{l}\text { Formerly used in the } \\
\text { production of rocket } \\
\text { fuels; presently used } \\
\text { as an anti-oxidant; as } \\
\text { an additive for lubri- } \\
\text { cants, and as a } \\
\text { softener for co- } \\
\text { polymers. }\end{array}$ & & & & & \\
\hline
\end{tabular}


Table F5. Properties of EPA priority pollutants (Continued).

\begin{tabular}{|c|c|c|c|c|c|c|c|c|c|c|c|c|}
\hline \multirow[t]{2}{*}{ Chemical } & \multirow[t]{2}{*}{ Synonyms } & \multirow{2}{*}{$\begin{array}{l}\text { b.p. } \\
\left({ }^{\circ} \mathrm{C}\right)\end{array}$} & \multicolumn{3}{|c|}{$\begin{array}{c}\text { Permissible Exposure } \\
\text { limits in Air } \\
\text { (Federal standard) } \\
\end{array}$} & \multirow[t]{2}{*}{ Notes } & \multirow[t]{2}{*}{ Uses } & \multirow[t]{2}{*}{$\begin{array}{l}\text { Molecular } \\
\text { weight }\end{array}$} & \multirow{2}{*}{$\begin{array}{l}\text { Density } \\
\mathrm{g} / \mathrm{ml}\end{array}$} & \multirow[t]{2}{*}{$\begin{array}{l}\text { Solubility } \\
\text { in water }\end{array}$} & \multirow{2}{*}{$\begin{array}{c}\text { Vapor } \\
\text { pressure } \\
\text { (mbar) }\end{array}$} & \multirow{2}{*}{$\begin{array}{l}\text { Diffusivity } \\
\left(\mathrm{cm}^{2} / \mathrm{s}\right)\end{array}$} \\
\hline & & & $\begin{array}{l}\text { TWA } \\
(\mathrm{ppm})\end{array}$ & $\begin{array}{l}\text { STEL } \\
(\mathrm{ppm}) \\
\end{array}$ & $\begin{array}{l}\text { IDLH } \\
(\mathrm{ppm})\end{array}$ & & & & & & & \\
\hline \multicolumn{13}{|c|}{$\begin{array}{l}\text { Chlorinated Hydrocarbons } \\
\text { Copt. }\end{array}$} \\
\hline $\begin{array}{l}\text { Bis (2-ethylhexyl) phthalate } \\
\mathrm{C}_{24} \mathrm{H}_{38} \mathrm{O}_{4}\end{array}$ & $\begin{array}{l}\text { Di-sec-Octyl Phhalate } \\
\text { DOP } \\
\text { DEH }\end{array}$ & 386 & $\begin{array}{c}5 \\
\mathrm{mg} / \mathrm{m}^{3}\end{array}$ & $\begin{array}{c}10 \\
\mathrm{mg} / \mathrm{m}^{3}\end{array}$ & $\begin{array}{l}9300 \\
\mathrm{mg} / \mathrm{m}^{3}\end{array}$ & $\begin{array}{l}\text { Irritates eyes and } \\
\text { mucous membranes; } \\
\text { can cause nausea } \\
\text { and diarthea. The } \\
\text { very low levels of } \\
\text { DEHP to which } \\
\text { humans are normally } \\
\text { exposed have not } \\
\text { been shown to cause } \\
\text { adverse health } \\
\text { effects. But DEHP } \\
\text { causes caucer in rats } \\
\text { and mice. }\end{array}$ & $\begin{array}{l}\text { As a plasticizer for } \\
\text { resins and in the } \\
\text { manufacture of } \\
\text { organic pump fluid. }\end{array}$ & 390.6 & .9861 & & $6 e-8$ & \\
\hline $\begin{array}{l}\text { Di-n-butyl phthalate } \\
\qquad \mathrm{C}_{6} \mathrm{H}_{4}\left(\mathrm{COOC}_{4} \mathrm{H}_{9}\right)_{2}\end{array}$ & \begin{tabular}{|l|} 
Dibutyl phthalate; \\
DBP; dibutyl \\
$1,2-$ \\
benzenedicarboxylate;
\end{tabular} & 340 & $\begin{array}{c}5 \\
\mathrm{~m} / \mathrm{m}^{3}\end{array}$ & $\begin{array}{c}10 \\
\mathrm{~m} / \mathrm{m}^{3}\end{array}$ & $\begin{array}{l}9300 \\
\mathrm{mg} / \mathrm{m}^{3}\end{array}$ & $\begin{array}{l}\text { Irritation of nasal } \\
\text { passages and upper } \\
\text { respiratory system; } \\
\text { stomach irritation; } \\
\text { light sensitivity; may } \\
\text { damage the } \\
\text { developing fetus and } \\
\text { may also damage the } \\
\text { male reproductive } \\
\text { glands. } \\
\end{array}$ & $\begin{array}{l}\text { Used in plasticizing } \\
\text { vinyl acetatal } \\
\text { emulsion systems and } \\
\text { in plasticizing } \\
\text { cellulose esters. Also } \\
\text { used as an insect } \\
\text { repellent. }\end{array}$ & 278.4 & 1.048 & & $2 e-5$ & \\
\hline $\begin{array}{l}\text { Di-n-octyl phthalate } \\
\quad \mathrm{C}_{6} \mathrm{H}_{4}\left(\mathrm{COOC}_{8} \mathrm{H}_{17}\right)_{2}\end{array}$ & $\begin{array}{l}\text { DOP } \\
\text { benzenedicarboxylic } \\
\text { acid di-n-octyl } \\
\text { ester }\end{array}$ & 220 & $\begin{array}{c}\text { not } \\
\text { defined }\end{array}$ & $\begin{array}{c}\text { not } \\
\text { defined }\end{array}$ & $\begin{array}{c}\text { not } \\
\text { defined }\end{array}$ & $\begin{array}{l}\text { Inhalation may } \\
\text { imritate the nose, } \\
\text { throat, and bronchial } \\
\text { tubes. High } \\
\text { exposure levels can } \\
\text { inritate the lungs, and } \\
\text { if prolonged, can } \\
\text { cause death. } \\
\end{array}$ & \begin{tabular}{|l} 
A plasticizer in \\
plastics product \\
manuffacture.
\end{tabular} & 391.0 & 0.978 & insoluble & & \\
\hline $\begin{array}{l}\text { Dimethyl phthalate } \\
\qquad \mathrm{C}_{6} \mathrm{H}_{4}\left(\mathrm{COOCH}_{3}\right)_{2}\end{array}$ & $\begin{array}{l}\text { Phthalic acid } \\
\text { dimethyl ester } \\
\text { dimethyl 1,2- } \\
\text { benzenedicarboxylate } \\
\text { DMP } \\
\text { ENT-262 }\end{array}$ & 282 & $\begin{array}{c}5 \\
\mathrm{mg} / \mathrm{m}^{3}\end{array}$ & $\begin{array}{c}10 \\
\mathrm{~m} / \mathrm{m}^{3}\end{array}$ & $\begin{array}{l}9300 \\
\mathrm{mg} / \mathrm{m}^{3}\end{array}$ & $\begin{array}{l}\text { Short term exposure } \\
\text { by intalation may } \\
\text { irritate the nose and } \\
\text { throat with coughing; } \\
\text { prolonged inhalation } \\
\text { may cause dizziness, } \\
\text { disorientation, loss } \\
\text { of coordination and } \\
\text { slowing of heart and } \\
\text { respiratory rate. } \\
\end{array}$ & $\begin{array}{l}\text { A plasticizer for } \\
\text { cellulose ester plas- } \\
\text { tics and as an insect } \\
\text { repellent }\end{array}$ & 194.2 & 1.189 & $5 \mathrm{~g} / 1$ & & \\
\hline
\end{tabular}




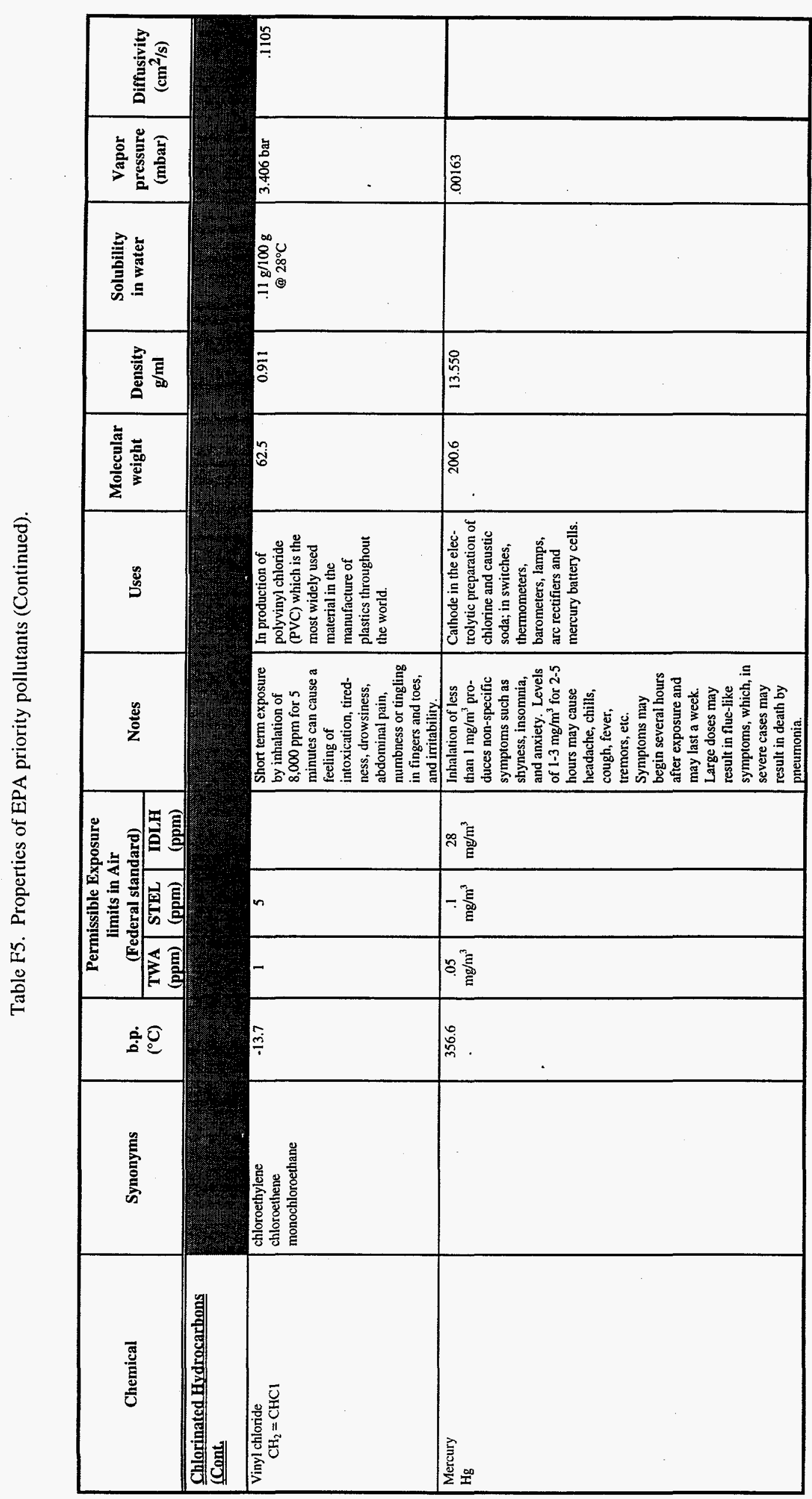




\begin{tabular}{|c|c|c|c|c|c|}
\hline & \multirow[t]{2}{*}{$\begin{array}{l}\text { Molecular } \\
\text { weight }\end{array}$} & \multicolumn{2}{|c|}{ Vapor pressure } & \multicolumn{2}{|c|}{ Concentration } \\
\hline & & (mbar) & $\left(\mathrm{N} / \mathrm{m}^{\wedge} 2\right)$ & (ppm) & $\left(\mathrm{mg} / \mathrm{m}^{\wedge} 3\right)$ \\
\hline Trichloroethylene & 131.39 & $\begin{array}{r}77.1 \\
1330\end{array}$ & $\begin{array}{r}7710 \\
13300\end{array}$ & $7.61 \mathrm{E}+04$ & $4.16 \mathrm{E}+05$ \\
\hline 1,1,1-Trichloroethane & 131.41 & 133.0 & & $1.31 E+05$ & $7.17 \mathrm{E}+05$ \\
\hline Tetrachloroethylene & 165.83 & 18.9 & 1890 & $1.87 \mathrm{E}+04$ & $1.29 \mathrm{E}+05$ \\
\hline Dichloromethane & 84.93 & 460.9 & 46090 & $4.55 \mathrm{E}+05$ & $1.61 \mathrm{E}+06$ \\
\hline Chlorobenzene & 112.56 & 11.7 & 1170 & $1.15 E+04$ & $5.40 \mathrm{E}+04$ \\
\hline 1,1-Dichloroethane & 98.96 & 242.7 & 24270 & $2.40 \mathrm{E}+05$ & $9.85 \mathrm{E}+05$ \\
\hline Vinyl Fluoride & 46.05 & 23960.0 & 2396000 & $2.36 \mathrm{E}+07$ & $4.53 \mathrm{E}+07$ \\
\hline 1,1-Dichlorethylene & 96.94 & 667.0 & 66700 & $6.58 \mathrm{E}+05$ & $2.65 \mathrm{E}+06$ \\
\hline 1,1-Dichloroethylene & 96.94 & 353.0 & 35300 & $3.48 \mathrm{E}+05$ & $1.40 \mathrm{E}+06$ \\
\hline 2-Chloronapthalene & 197.06 & & & & \\
\hline Carbon Tetrachloride & 153.82 & 119.4 & 11940 & $1.18 \mathrm{E}+05$ & $7.54 \mathrm{E}+05$ \\
\hline Chloroform & 119.38 & 213.0 & 21300 & $2.10 \mathrm{E}+05$ & $1.04 E+06$ \\
\hline Freon-12 & 120.91 & 5.7 & 567 & $5.59 \mathrm{E}+03$ & $2.81 \mathrm{E}+04$ \\
\hline 1,2-Dichloroethane & 98.96 & 242.7 & 24270 & $2.40 \mathrm{E}+05$ & $9.85 \mathrm{E}+05$ \\
\hline 1,2-Dichloroethane & 98.96 & 85.9 & 8590 & $8.48 \mathrm{E}+04$ & $3.49 E+05$ \\
\hline $1,1,2,2$-Tetrachloroethane & 167.85 & 6.5 & 647 & $6.39 \mathrm{E}+03$ & $4.46 \mathrm{E}+04$ \\
\hline Acetone & 58.08 & 247.0 & 24700 & $2.44 \mathrm{E}+05$ & $5.89 \mathrm{E}+05$ \\
\hline Methyl Ethyl Ketone & 72.12 & 105.0 & 10500 & $1.04 \mathrm{E}+05$ & $3.11 \mathrm{E}+05$ \\
\hline Methyl Isobutyl Ketone & 100.16 & 20.2 & 2020 & $1.99 \mathrm{E}+04$ & $8.30 \mathrm{E}+04$ \\
\hline Toluene & 92.15 & 27.8 & 2780 & $2.74 \mathrm{E}+04$ & $1.05 \mathrm{E}+05$ \\
\hline Xylenes & 106.17 & 1.0 & 100 & $9.87 \mathrm{E}+02$ & $4.36 \mathrm{E}+03$ \\
\hline Ethylbenzene & 106.17 & 9.3 & 930 & $9.18 \mathrm{E}+03$ & $4.05 \mathrm{E}+04$ \\
\hline Benzene & 78.12 & 99.7 & 9970 & $9.84 \mathrm{E}+04$ & $3.20 \mathrm{E}+05$ \\
\hline n-Hexane & 86.18 & 160.0 & 16000 & $1.58 \mathrm{E}+05$ & $5.66 \mathrm{E}+05$ \\
\hline Cyclohexane & 84.16 & 103.0 & 10300 & $1.02 \mathrm{E}+05$ & $3.56 \mathrm{E}+05$ \\
\hline Butyl Benzyl Phthalate & 312.36 & & & & \\
\hline Diethyl Phthalate & 222.24 & & & & \\
\hline Chlorodane & 409.78 & 0.0 & 0 & $1.28 \mathrm{E}-03$ & $2.19 \mathrm{E}-02$ \\
\hline Polychlorinated Biphenyls & & & & & \\
\hline Tributyl Phosphate & 266.32 & & & & \\
\hline Acetonitrile & 41.05 & 97.0 & 9700 & $9.57 \mathrm{E}+04$ & $1.63 \mathrm{E}+05$ \\
\hline Isopropyl Alcohol & 60.11 & 41.6 & 4160 & $4.11 \mathrm{E}+04$ & $1.03 \mathrm{E}+05$ \\
\hline Tetrahydrofuran & 72.11 & 200.0 & 20000 & $1.97 \mathrm{E}+05$ & $5.92 \mathrm{E}+05$ \\
\hline Carbon Disulfide & 76.14 & 397.0 & 39700 & $3.92 \mathrm{E}+05$ & $1.24 \mathrm{E}+06$ \\
\hline Acrolein & 56.10 & 286.0 & 28600 & $2.82 \mathrm{E}+05$ & $6.58 \mathrm{E}+05$ \\
\hline Acrylonitrile & 53.10 & 124.0 & 12400 & $1.22 \mathrm{E}+05$ & $2.70 \mathrm{E}+05$ \\
\hline 1,2,4-Trichlorobenzene & 181.50 & 0.3 & 26 & $2.57 \mathrm{E}+02$ & $1.94 \mathrm{E}+03$ \\
\hline 1,1,2-Trichloroethane & 133.40 & 29.0 & 2900 & $2.86 \mathrm{E}+04$ & $1.59 \mathrm{E}+05$ \\
\hline
\end{tabular}


Table F6. Calculated maximum vapor concentrations for chemicals of interest (Continued).

\begin{tabular}{|c|c|c|c|c|c|}
\hline & \multirow[t]{2}{*}{$\begin{array}{c}\text { Molecular } \\
\text { weight }\end{array}$} & \multicolumn{2}{|c|}{ Vapor pressure } & \multicolumn{2}{|c|}{ Concentration } \\
\hline & & (mbar) & $\left(\mathrm{N} / \mathrm{m}^{\wedge} 2\right)$ & $(\mathrm{ppm})$ & $\left(\mathrm{mg} / \mathrm{m}^{\wedge} 3\right)$ \\
\hline $\begin{array}{l}\text { Chloroethane } \\
\text { Bis(chloromethyl) ether }\end{array}$ & $\begin{array}{r}64.50 \\
115.00\end{array}$ & 1.3 & 133 & $1.31 \mathrm{E}+03$ & $3.52 \mathrm{E}+03$ \\
\hline Bis(2-chloroethyl) ether & 143.00 & 1.1 & 107 & $1.06 \mathrm{E}+03$ & $6.28 \mathrm{E}+03$ \\
\hline 2-Chloroethyl vinyl ether & 106.55 & & & & \\
\hline 2-Chlorophenol & 128.40 & 1.3 & 130 & $1.28 \mathrm{E}+03$ & $6.85 E+03$ \\
\hline 1,2-Dichlorobenzene & 147.00 & 1.3 & 130 & $1.28 \mathrm{E}+03$ & $7.84 \mathrm{E}+03$ \\
\hline 1,3-Dichlorobenzene & 147.00 & 2.9 & 293 & $2.89 \mathrm{E}+03$ & $1.76 \mathrm{E}+04$ \\
\hline 1,2-Dichloropropane & 113.00 & 56.0 & 5600 & $5.53 \mathrm{E}+04$ & $2.60 \mathrm{E}+05$ \\
\hline 1,2-Dichloropropylene & 110.00 & & & & \\
\hline Methyl chloride & 50.50 & 4896.0 & 489600 & $4.83 E+06$ & $1.01 \mathrm{E}+07$ \\
\hline Methyl bromide & 94.90 & 1890.0 & 189000 & $1.87 \mathrm{E}+06$ & $7.36 \mathrm{E}+06$ \\
\hline Bromoform & 252.70 & 6.7 & 670 & $6.61 \mathrm{E}+03$ & $6.95 \mathrm{E}+04$ \\
\hline Dichlorobromomethane & & & & & \\
\hline Trichlorofluoromethane & 137.40 & 8865.0 & 886500 & $8.75 E+06$ & $5.00 \mathrm{E}+07$ \\
\hline Dichlorodifluoromethane & 120.90 & 5669.0 & 566900 & $5.59 \mathrm{E}+06$ & $2.81 \mathrm{E}+07$ \\
\hline Chlorodibromomethane & & & & & \\
\hline Hexachlorobutadiene & 260.76 & 0.2 & 20 & $1.97 \mathrm{E}+02$ & $2.13 E+03$ \\
\hline Hexachlorocyclopentadien & 272.70 & 1.3 & 133 & $1.31 \mathrm{E}+03$ & $1.49 \mathrm{E}+04$ \\
\hline Isophorone & 138.20 & 0.3 & 33 & $3.26 \mathrm{E}+02$ & $1.87 \mathrm{E}+03$ \\
\hline Nitrobenzene & 123.10 & 0.2 & 20 & $1.97 \mathrm{E}+02$ & $1.01 \mathrm{E}+03$ \\
\hline $\mathrm{N}$-nitrosodimethylamine & 74.08 & & & & \\
\hline Bis (2-ethylhexyl) & 390.60 & 0.0 & 0 & 5.92E-05 & $9.62 \mathrm{E}-04$ \\
\hline Di-n-butyl phthalate & 278.40 & 0.0 & 0 & $1.97 \mathrm{E}-02$ & $2.28 \mathrm{E}-01$ \\
\hline Di-n-octyl phthalate & 391.00 & & & & \\
\hline Dimethyl phthalate & 194.20 & & & & \\
\hline Vinyl Chloride & 62.50 & 3406.0 & 340600 & $3.36 \mathrm{E}+06$ & $8.73 \mathrm{E}+06$ \\
\hline Mercury & 200.60 & 0.0 & 0 & $1.61 \mathrm{E}+00$ & $1.34 \mathrm{E}+01$ \\
\hline
\end{tabular}




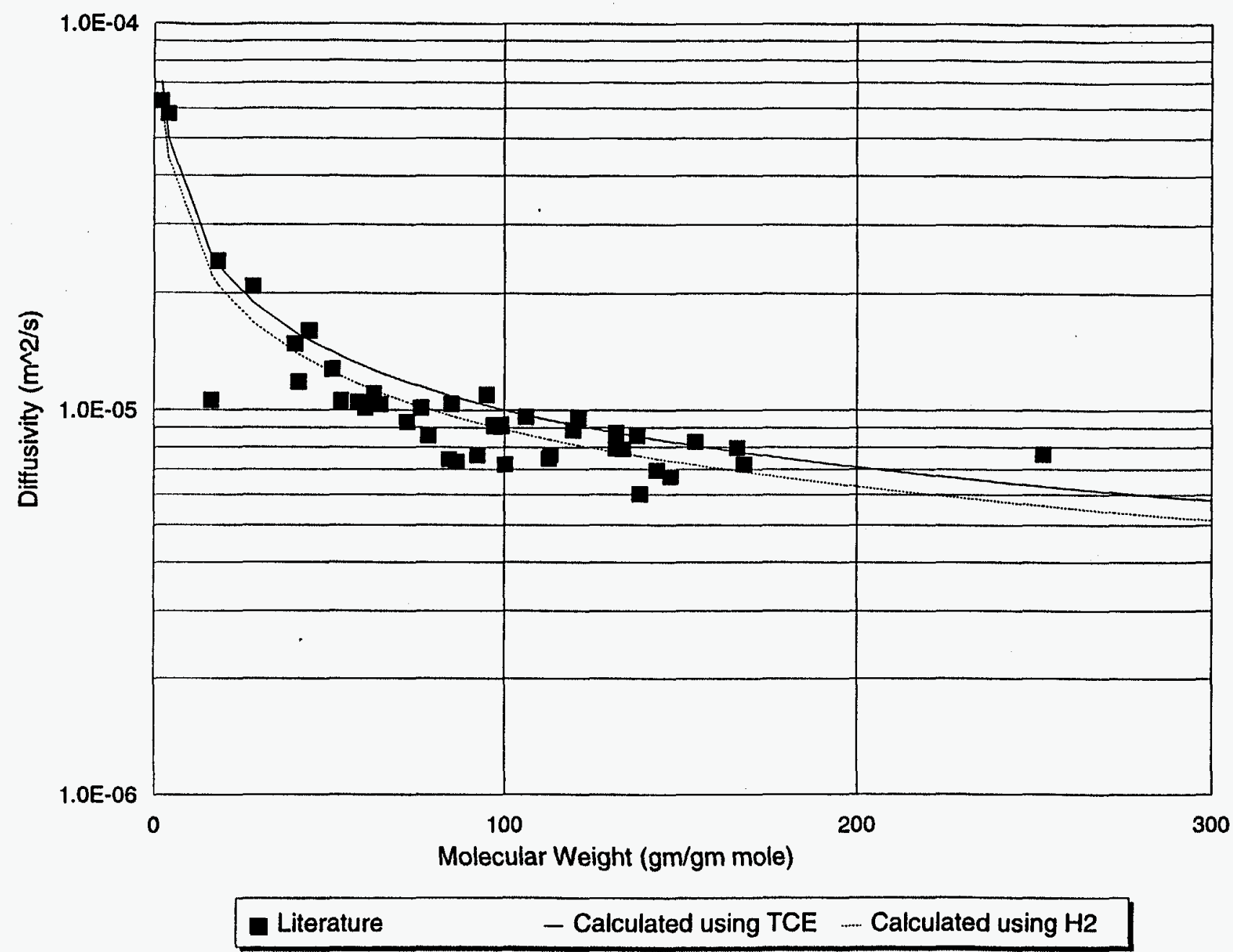




\begin{tabular}{|c|c|c|c|c|c|c|}
\hline & \multirow{3}{*}{$\begin{array}{l}\text { Molecular } \\
\text { weight } \\
\text { (gm/gm moles) }\end{array}$} & \multicolumn{2}{|c|}{ Diffusivity constant in air $\left(\mathrm{m}^{2} / \mathrm{s}\right)$} & \multirow{2}{*}{\multicolumn{3}{|c|}{$\begin{array}{c}\text { Diffusivity constant in soil pores (m2/s) } \\
\text { calculated from Grahm's Law } \\
\text { using TCE and tortuosities: }\end{array}$}} \\
\hline & & from & $\begin{array}{c}\text { calculated from } \\
\text { Grahm's Law }\end{array}$ & & & \\
\hline & & & using TCE & 0.3 & 0.5 & 0.7 \\
\hline Acetonitrile & 41.1 & $1.181 \mathrm{E}-04$ & $1.565 \mathrm{E}-04$ & $4.696 \mathrm{E}-05$ & $7.827 \mathrm{E}-05$ & $1.096 \mathrm{E}-04$ \\
\hline Vinyl Fluoride & 46.1 & & $1.478 \mathrm{E}-04$ & 4.434E-05 & $7.390 \mathrm{E}-05$ & $1.035 \mathrm{E}-04$ \\
\hline Methyl Chloride & 50.5 & $1.276 \mathrm{E}-04$ & $1.411 \mathrm{E}-04$ & $4.234 \mathrm{E}-05$ & 7.057E-05 & $9.880 \mathrm{E}-05$ \\
\hline Acrylonitrile & 53.1 & $1.059 \mathrm{E}-04$ & $1.376 \mathrm{E}-04$ & $4.129 \mathrm{E}-05$ & $6.882 \mathrm{E}-05$ & $9.635 \mathrm{E}-05$ \\
\hline Acrolein & 56.1 & & $1.339 \mathrm{E}-04$ & 4.017E-05 & $6.695 \mathrm{E}-05$ & $9.374 \mathrm{E}-05$ \\
\hline Acetone & 58.1 & $1.049 \mathrm{E}-04$ & $1.316 \mathrm{E}-04$ & $3.948 \mathrm{E}-05$ & $6.580 \mathrm{E}-05$ & $9.212 \mathrm{E}-05$ \\
\hline Isopropyl Alcohol & 60.1 & $1.013 \mathrm{E}-04$ & $1.294 \mathrm{E}-04$ & $3.881 \mathrm{E}-05$ & $6.468 \mathrm{E}-05$ & $9.056 \mathrm{E}-05$ \\
\hline Vinyl Chloride & 62.5 & $1.105 \mathrm{E}-04$ & $1.269 \mathrm{E}-04$ & $3.806 \mathrm{E}-05$ & $6.343 \mathrm{E}-05$ & 8.881E-05 \\
\hline Chloroethane & 64.5 & $1.036 \mathrm{E}-04$ & $1.249 \mathrm{E}-04$ & $3.747 \mathrm{E}-05$ & $6.244 \mathrm{E}-05$ & $8.742 \mathrm{E}-05$ \\
\hline Tetrahydrofuran & 72.1 & $9.330 \mathrm{E}-05$ & $1.181 \mathrm{E}-04$ & $3.543 \mathrm{E}-05$ & $5.906 \mathrm{E}-05$ & $8.268 \mathrm{E}-05$ \\
\hline Methyl Ethyl Ketone & 72.1 & & $1.181 \mathrm{E}-04$ & 3.543E-05 & $5.905 \mathrm{E}-05$ & 8.267E-05 \\
\hline N-nitrosodimethylamine & 74.1 & & $1.165 \mathrm{E}-04$ & $3.496 \mathrm{E}-05$ & $5.826 \mathrm{E}-05$ & 8.157E-05 \\
\hline Carbon Disulfide & 76.1 & $1.013 \mathrm{E}-04$ & $1.149 \mathrm{E}-04$ & $3.448 \mathrm{E}-05$ & 5.747E-05 & $8.046 \mathrm{E}-05$ \\
\hline Benzene & 78.1 & $8.590 \mathrm{E}-05$ & $1.135 \mathrm{E}-04$ & $3.404 \mathrm{E}-05$ & $5.674 \mathrm{E}-05$ & 7.943E-05 \\
\hline Cyclohexane & 84.2 & $7.440 \mathrm{E}-05$ & $1.093 \mathrm{E}-04$ & $3.280 \mathrm{E}-05$ & $5.466 \mathrm{E}-05$ & 7.653E-05 \\
\hline Dichloromethane & 84.9 & $1.037 \mathrm{E}-04$ & $1.088 \mathrm{E}-04$ & $3.265 \mathrm{E}-05$ & $5.442 \mathrm{E}-05$ & $7.618 \mathrm{E}-05$ \\
\hline n-Hexane & 86.2 & $7.320 \mathrm{E}-05$ & $1.080 \mathrm{E}-04$ & $3.241 \mathrm{E}-05$ & $5.402 \mathrm{E}-05$ & $7.563 \mathrm{E}-05$ \\
\hline Toluene & 92.2 & $7.630 \mathrm{E}-05$ & $1.045 \mathrm{E}-04$ & 3.134E-05 & $5.224 \mathrm{E}-05$ & 7.314E-05 \\
\hline Methyl Bromide & 94.9 & $1.096 \mathrm{E}-04$ & $1.030 \mathrm{E}-04$ & $3.089 \mathrm{E}-05$ & $5.148 \mathrm{E}-05$ & 7.207E-05 \\
\hline 1,1-Dichlorethylene & 96.9 & $9.180 \mathrm{E}-05$ & $1.019 \mathrm{E}-04$ & $3.056 \mathrm{E}-05$ & 5.093E-05 & $7.131 \mathrm{E}-05$ \\
\hline 1,1-Dichloroethylene & 96.9 & $9.110 \mathrm{E}-05$ & $1.019 \mathrm{E}-04$ & $3.056 \mathrm{E}-05$ & $5.093 \mathrm{E}-05$ & 7.131E-05 \\
\hline 1,2-Dichloroethane & 99.0 & $9.070 \mathrm{E}-05$ & $1.008 \mathrm{E}-04$ & $3.025 \mathrm{E}-05$ & $5.041 \mathrm{E}-05$ & $7.058 \mathrm{E}-05$ \\
\hline 1,2-Dichloroethane & 99.0 & $9.190 \mathrm{E}-05$ & $1.008 \mathrm{E}-04$ & $3.025 \mathrm{E}-05$ & $5.041 \mathrm{E}-05$ & $7.058 \mathrm{E}-05$ \\
\hline 1,1-Dichloroethane & 99.0 & $9.190 \mathrm{E}-05$ & $1.008 \mathrm{E}-04$ & $3.025 \mathrm{E}-05$ & $5.041 \mathrm{E}-05$ & $7.058 \mathrm{E}-05$ \\
\hline Methyl Isobutyl Ketone & 100.2 & $7.220 \mathrm{E}-05$ & $1.002 \mathrm{E}-04$ & 3.007E-05 & $5.011 \mathrm{E}-05$ & $7.015 \mathrm{E}-05$ \\
\hline Ethylbenzene & 106.2 & $9.630 \mathrm{E}-05$ & $9.734 \mathrm{E}-05$ & $2.920 \mathrm{E}-05$ & $4.867 \mathrm{E}-05$ & $6.814 \mathrm{E}-05$ \\
\hline Xylenes & 106.2 & & 9.734E-05 & $2.920 \mathrm{E}-05$ & $4.867 \mathrm{E}-05$ & $6.814 \mathrm{E}-05$ \\
\hline 2-Chloroethyl vinyl ether & 106.6 & & $9.716 \mathrm{E}-05$ & 2.915E-05 & 4.858E-05 & $6.802 \mathrm{E}-05$ \\
\hline 1,2-Dichloropropylene & 110.0 & & $9.563 \mathrm{E}-05$ & $2.869 \mathrm{E}-05$ & $4.781 \mathrm{E}-05$ & $6.694 \mathrm{E}-05$ \\
\hline Chlorobenzene & 112.6 & $7.470 \mathrm{E}-05$ & $9.454 \mathrm{E}-05$ & $2.836 \mathrm{E}-05$ & 4.727E-05 & $6.618 \mathrm{E}-05$ \\
\hline 1,2-Dichloropropane & 113.0 & $7.650 \mathrm{E}-05$ & $9.435 \mathrm{E}-05$ & $2.831 \mathrm{E}-05$ & $4.718 \mathrm{E}-05$ & $6.605 \mathrm{E}-05$ \\
\hline Bis(chloromethyl) ether & 115.0 & & 9.353E-05 & $2.806 \mathrm{E}-05$ & $4.676 \mathrm{E}-05$ & $6.547 \mathrm{E}-05$ \\
\hline Chloroform & 119.4 & $8.880 \mathrm{E}-05$ & $9.180 \mathrm{E}-05$ & $2.754 \mathrm{E}-05$ & $4.590 \mathrm{E}-05$ & $6.426 \mathrm{E}-05$ \\
\hline Dichlorodifluoromethane & 120.9 & $9.580 \mathrm{E}-05$ & $9.122 \mathrm{E}-05$ & 2.737E-05 & $4.561 \mathrm{E}-05$ & $6.385 \mathrm{E}-05$ \\
\hline Freon-12 & 120.9 & 9.580E-05 & $9.121 \mathrm{E}-05$ & $2.736 \mathrm{E}-05$ & $4.561 \mathrm{E}-05$ & $6.385 \mathrm{E}-05$ \\
\hline
\end{tabular}


Table F7. Calculated effective diffusivity constants of contaminants in soil with a 35 percent air filled porosity and tortuosities of $0.3,0.5$, and 0.7 .

\begin{tabular}{|c|c|c|c|c|c|c|}
\hline & $\begin{array}{c}\text { Molecular } \\
\text { weight }\end{array}$ & $\begin{array}{l}\text { Diffusivity } \\
\text { from } \\
\text { literature }\end{array}$ & $\begin{array}{c}\text { onstant in air }\left(\mathrm{m}^{2} / \mathrm{s}\right) \\
\text { calculated from } \\
\text { Grahm's Law }\end{array}$ & $\begin{array}{r}\text { Diffusiv } \\
\text { calculate } \\
\text { using T }\end{array}$ & $\begin{array}{l}\text { y constant it } \\
\mathrm{CE} \text { from Graht } \\
\mathrm{CE} \text { tortu }\end{array}$ & $\begin{array}{l}\text { soil pores } \\
\text { I's Law of } \\
\text { sities of: }\end{array}$ \\
\hline & (gm/gm moles) & & using TCE & 0.3 & 0.5 & \\
\hline Nitrobenzene & 123.1 & & $9.040 \mathrm{E}-05$ & $2.712 \mathrm{E}-05$ & $4.520 \mathrm{E}-05$ & $6.328 \mathrm{E}-05$ \\
\hline 2-Chlorophenol & 128.4 & & $8.851 \mathrm{E}-05$ & $2.655 \mathrm{E}-05$ & $4.426 \mathrm{E}-05$ & $6.196 \mathrm{E}-05$ \\
\hline Trichloroethylene & 131.4 & $8.750 \mathrm{E}-05$ & $8.750 \mathrm{E}-05$ & $2.625 \mathrm{E}-05$ & $4.375 \mathrm{E}-05$ & $6.125 \mathrm{E}-05$ \\
\hline 1,1,1-Trichloroethane & 131.4 & $7.940 \mathrm{E}-05$ & $8.749 \mathrm{E}-05$ & $2.625 \mathrm{E}-05$ & $4.375 \mathrm{E}-05$ & $6.125 \mathrm{E}-05$ \\
\hline 1,1,2-Trichloroethane & 133.4 & $7.920 \mathrm{E}-05$ & $8.684 \mathrm{E}-05$ & $2.605 \mathrm{E}-05$ & 4.342E-05 & $6.079 \mathrm{E}-05$ \\
\hline Trichlorofluoromethane & 137.4 & $8.580 \mathrm{E}-05$ & $8.556 \mathrm{E}-05$ & $2.567 \mathrm{E}-05$ & $4.278 \mathrm{E}-05$ & $5.990 \mathrm{E}-05$ \\
\hline Isophorone & 138.2 & $6.020 \mathrm{E}-05$ & 8.532E-05 & $2.560 \mathrm{E}-05$ & 4.266E-05 & 5.972E-05 \\
\hline Bis(2-chloroethyl) ether & 143.0 & $6.940 \mathrm{E}-05$ & $8.387 \mathrm{E}-05$ & $2.516 \mathrm{E}-05$ & 4.194E-05 & $5.871 \mathrm{E}-05$ \\
\hline Sulfer Hexafluoride & 146.1 & & $8.299 \mathrm{E}-05$ & $2.490 \mathrm{E}-05$ & 4.149E-05 & $5.809 \mathrm{E}-05$ \\
\hline 1,2-Dichlorobenzene & 147.0 & $6.680 \mathrm{E}-05$ & $8.272 \mathrm{E}-05$ & $2.482 \mathrm{E}-05$ & $4.136 \mathrm{E}-05$ & $5.791 \mathrm{E}-05$ \\
\hline 1,3-Dichlorobenzene & 147.0 & & $8.272 \mathrm{E}-05$ & $2.482 \mathrm{E}-05$ & $4.136 \mathrm{E}-05$ & $5.791 \mathrm{E}-05$ \\
\hline Carbon Tetrachloride & 153.8 & $8.280 \mathrm{E}-05$ & $8.087 \mathrm{E}-05$ & $2.426 \mathrm{E}-05$ & $4.043 \mathrm{E}-05$ & 5.661E-05 \\
\hline Tetrachloroethylene & 165.8 & $7.970 \mathrm{E}-05$ & $7.789 \mathrm{E}-05$ & $2.337 \mathrm{E}-05$ & 3.894E-05 & $5.452 \mathrm{E}-05$ \\
\hline 1,1,2,2-Tetrachloroethane & 167.9 & $7.220 \mathrm{E}-05$ & 7.742E-05 & $2.322 \mathrm{E}-05$ & 3.871E-05 & $5.419 \mathrm{E}-05$ \\
\hline 1,2,4-Trichlorobenzene & 181.5 & & $7.445 \mathrm{E}-05$ & $2.233 \mathrm{E}-05$ & $3.722 \mathrm{E}-05$ & $5.211 \mathrm{E}-05$ \\
\hline Dimethyl Phthalate & 194.2 & & 7.197E-05 & $2.159 \mathrm{E}-05$ & $3.599 \mathrm{E}-05$ & 5.038E-05 \\
\hline 2-Chloronaphthalene & 197.1 & & $7.145 \mathrm{E}-05$ & $2.143 \mathrm{E}-05$ & $3.572 \mathrm{E}-05$ & $5.001 \mathrm{E}-05$ \\
\hline Mercury & 200.6 & & $7.081 \mathrm{E}-05$ & $2.124 \mathrm{E}-05$ & $3.541 \mathrm{E}-05$ & 4.957E-05 \\
\hline Diethyl Phthalate & 222.2 & & $6.728 \mathrm{E}-05$ & $2.018 \mathrm{E}-05$ & 3.364E-05 & $4.710 \mathrm{E}-05$ \\
\hline Bromoform & 252.7 & 7.670E-05 & $6.309 \mathrm{E}-05$ & $1.893 \mathrm{E}-05$ & 3.155E-05 & $4.417 \mathrm{E}-05$ \\
\hline Hexachlorobutadiene & 260.8 & & $6.211 \mathrm{E}-05$ & $1.863 \mathrm{E}-05$ & $3.106 \mathrm{E}-05$ & $4.348 \mathrm{E}-05$ \\
\hline Hexachlorocyclopentadiene & 272.7 & & $6.074 \mathrm{E}-05$ & $1.822 \mathrm{E}-05$ & $3.037 \mathrm{E}-05$ & $4.252 \mathrm{E}-05$ \\
\hline Di-n-butyl Phthalate & 278.4 & & $6.011 \mathrm{E}-05$ & $1.803 \mathrm{E}-05$ & $3.006 \mathrm{E}-05$ & $4.208 \mathrm{E}-05$ \\
\hline Butyl Benzyl Phthalate & 312.4 & & $5.675 \mathrm{E}-05$ & $1.702 \mathrm{E}-05$ & $2.837 \mathrm{E}-05$ & 3.972E-05 \\
\hline $\begin{array}{l}\text { Bis (2-ethylhexyl) } \\
\text { phthalate }\end{array}$ & 390.6 & & $5.075 \mathrm{E}-05$ & $1.522 \mathrm{E}-05$ & $2.537 \mathrm{E}-05$ & $3.552 \mathrm{E}-05$ \\
\hline Di-n-octyl Phthalate & 391.0 & & $5.072 \mathrm{E}-05$ & $1.522 \mathrm{E}-05$ & $2.536 \mathrm{E}-05$ & 3.551E-05 \\
\hline Chlordane & 409.8 & & $4.955 \mathrm{E}-05$ & $1.486 \mathrm{E}-05$ & $2.477 \mathrm{E}-05$ & $3.468 \mathrm{E}-05$ \\
\hline
\end{tabular}




\section{REFERENCES}

B1. Youngquist, G. R., Diffusion and Flow of Gases in Porous Solids.

B3. Holman, J. P., ed., Heat Transfer, second edition, pp. 79, McGraw Hill.

B4. Lowry, W. E., et al., "Large Scale Vapor Movement Test: Analysis of Barometric Pressure-Induced Soil Vapor Flux," topical report, SEASF-TR-93-028, October 1993.

C1. Davies, "Heat Storage and Distribution Inside Passive Solar Buildings," Los Alamos National Laboratories, LA-9464-MS, Page 24.

G1. Weast, R. C. Ed., CRC Handbook of Chemistry and Physics, 58th ed., CRC Press, Inc., Cleveland, OH 1977.

G2. Voice, The Dräger Tube Information System, Version 1.0, National Dräger, Inc., Pittsburgh, PA, 1992.

G3 Sittig, M., Handbook of Toxic and Hazardous Chemicals and Carcinogens, third ed. Volumes 1 and 2, Noyes Publications, Park Ridge, NJ, 1991.

G4. Editor, Sittig, M., "Priority Toxic Pollutants, Health Impacts and Allowable Limits", Noyes Data Corporation, park Ridge, NJ, 1980

G5. Riley, R. G. And Zachara, J. M., "Nature of Chemical Contaminants on DOE Lands and Identification of Representative Contaminant Mixtures for Basic Subsurface Science Research," June 1991, prepared for the U.S. Department of Energy under contract DE-AC06-76RLO 1830.

G6. Mavon, S. H. And Lando, J. B., "Fundamentals of Physical Chemistry," Macmillan Publishing Co., Inc., New York, NY, 1974.

G7 Bear, J., Dynamics of Fluids in Porous Media, American Elsevien Publishing Company, Inc., New York, NY. 